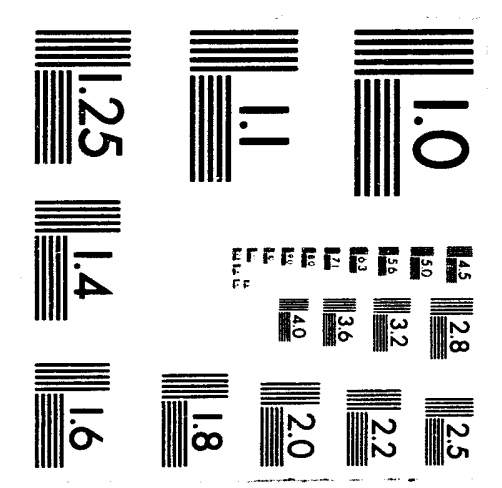



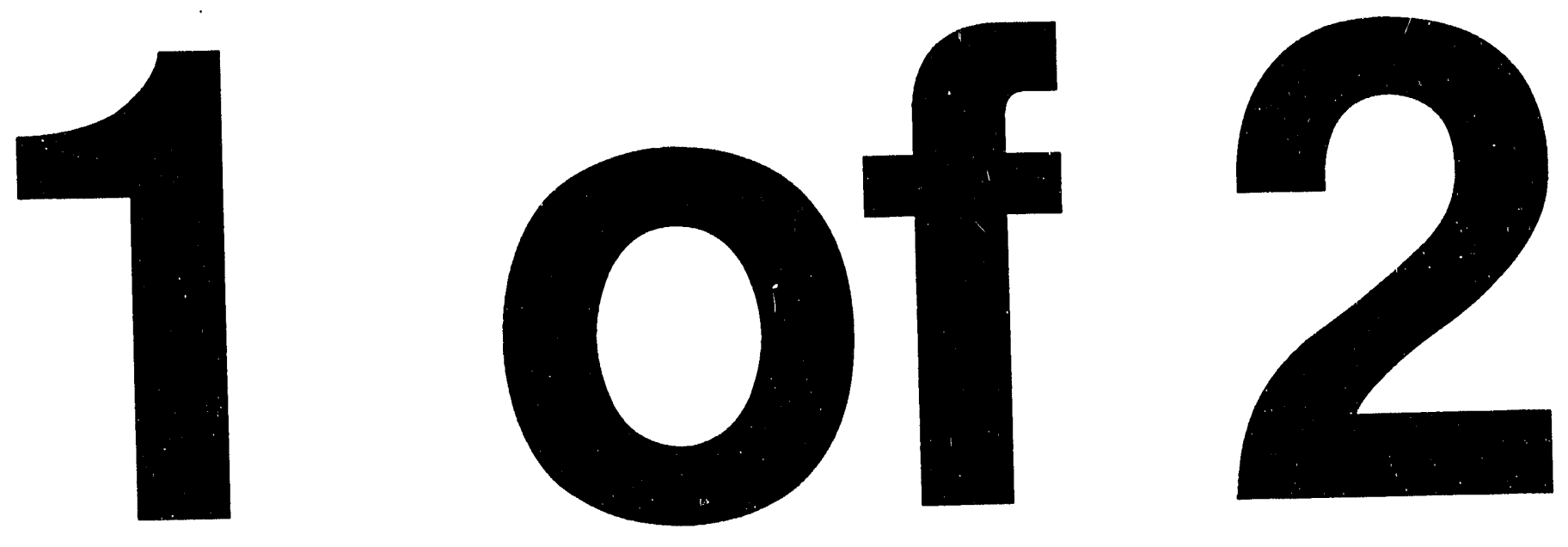


\section{Work Plan for the Remedial Investigation/ Feasibility Study-Environmental Assessment for the Quarry Residuals Operable Unit at the Weldon Spring Site}

January 1994

prepared by

Environmental Assessment Division, Argonne National Laboratory

prepared for

U.S. Department of Energy, Weldon Spring Site Remedial Action Project, St. Charles, Missouri under Contract W-31-109-Eng-38 


\section{CONTENTS}

FIGURES $\ldots \ldots \ldots \ldots \ldots \ldots \ldots \ldots \ldots \ldots \ldots \ldots \ldots \ldots \ldots$

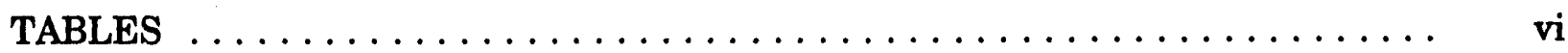

NOTATION $\ldots \ldots \ldots \ldots \ldots \ldots \ldots \ldots \ldots \ldots \ldots \ldots \ldots \ldots \ldots$

ENGLISH/METRIC AND METRIC/ENGLISH EQUIVALENTS $\ldots \ldots \ldots \ldots \ldots$ xi

1 INTRODUCTION $\ldots \ldots \ldots \ldots \ldots \ldots \ldots \ldots \ldots \ldots \ldots \ldots \ldots$

1.1 General Site Information . . . . . . . . . . . . . . . . . 4

1.2 Justification and Objectives for the Proposed Action $\ldots \ldots \ldots \ldots \ldots \ldots$

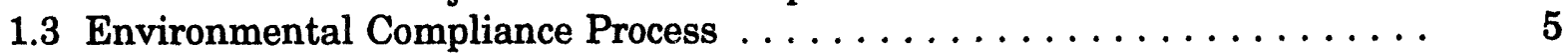

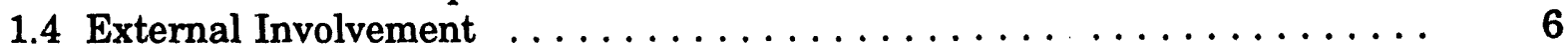

1.4.1 Coordination with Other Agencies . . . . . . . . . . . . . 6

1.1 .2 Summary of the Federal Facility Agreement . . . . . . . . . . 6

1.4.3 Public Participation . . . . . . . . . . . . . $7 \ldots \ldots \ldots$

2 SITE BACKGROUND AND SETTING $\ldots \ldots \ldots \ldots \ldots \ldots \ldots$

2.1 Site Description $\ldots \ldots \ldots \ldots \ldots \ldots \ldots \ldots \ldots \ldots \ldots \ldots \ldots \ldots$

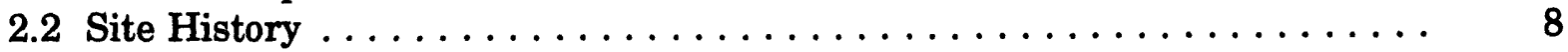

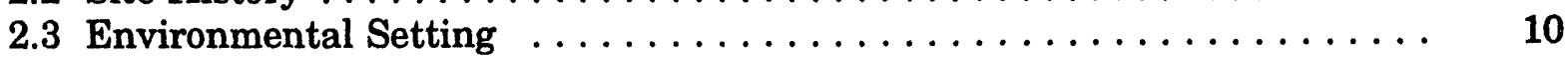

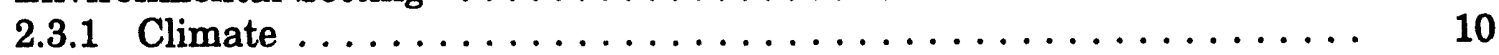

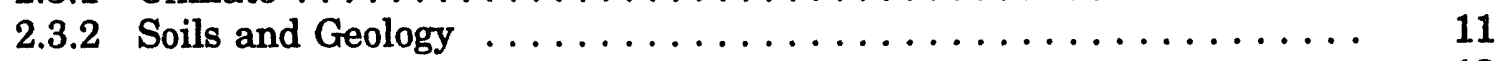

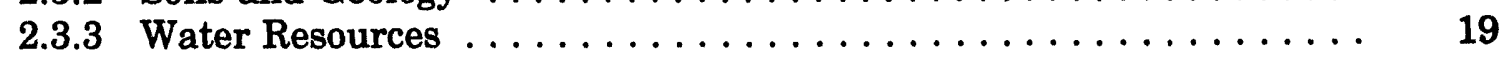

2.3.3.1 Surface Water Hydrology . . . . . . . . . . . . . 19

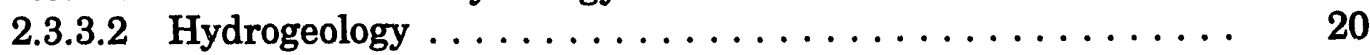

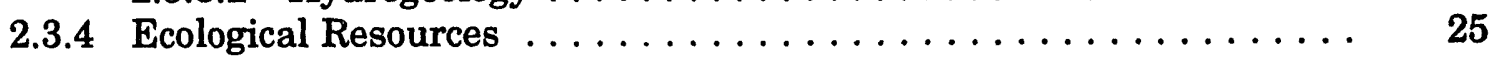

2.3.5 Historic Resources . . . . . . . . . . . . . . . . . . 26

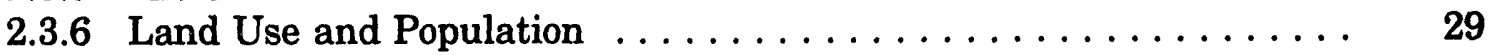

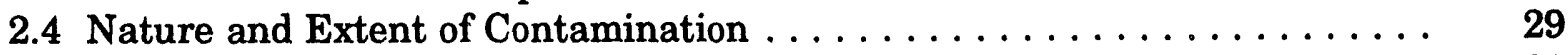

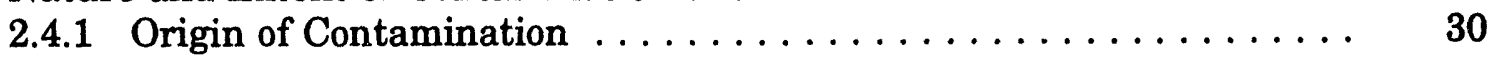

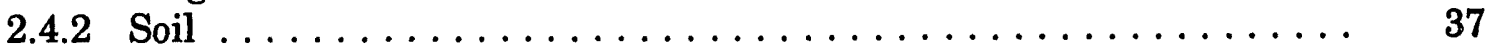

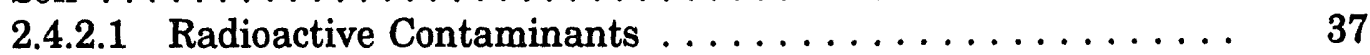

2.4.2.2 Chemical Contaminants .................. 41

2.4 .3 Surface Water . . . . . . . . . . . . . . . . . . . . 42

2.4.3.1 Radioactive Contaminants ................ 42

2.4.3.2 Chemical Contaminants ................. 46

2.4 .4 Sediment . . . . . . . . . . . . . . . . . . . . . 46

2.4.4.1 Radioactive Contaminants ................ 46

2.4.4.2 Chemical Contaminants .................. 46

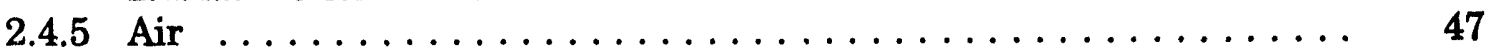

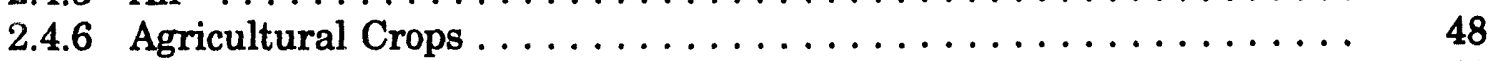

2.4 .7 Groundwater ........................... 48

2.4.7.1 Radioactive Contaminants ................ 54

2.4.7.2 Chemical Contaminants .................. 62 


\section{CONTENTS (Cont.)}

3 INITIAL SITE EVAI,UATION $\ldots \ldots \ldots \ldots \ldots \ldots$

3.1 Conceptual Site Model $\ldots \ldots \ldots \ldots \ldots \ldots \ldots \ldots$

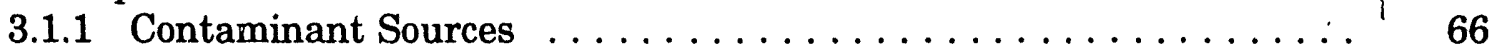

3.1.2 Radioactive and Chemical Contaminants .............. 68

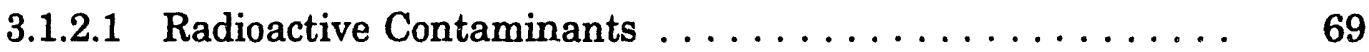

3.1.2.2 Chemical Contaminants . . . . . . . . . . . . . . 71

3.1.3 Potential Release and Transport Mechanisms ............. 74

3.1.3.1 Residual Material .................... 75

3.1.3.2 Contaminated Soil . . . . . . . . . . . . . . . 76

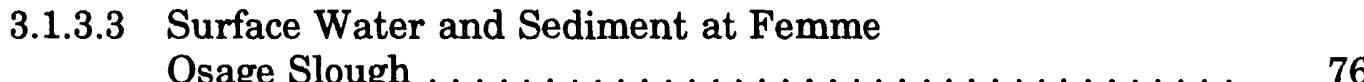

3.1.4 Potential Human Receptors and Routes of Exposure . . . . . . . . 77

3.1.4.1 Quarry Proper ...................... 77

3.1.4.2 Areas Outside of the Quarry Proper .............. 78

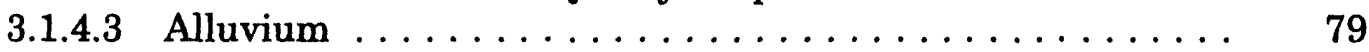

3.1.4.4 Fish, Game, and Agricultural Crops ............ 79

3.1.5 Potential Ecological Receptors and Routes of Exposure . . . . . . . . 79

3.2 Toxicological and Environmental Properties

of Selected Contaminants $\ldots \ldots \ldots \ldots \ldots \ldots \ldots \ldots \ldots \ldots$

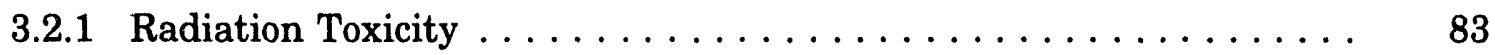

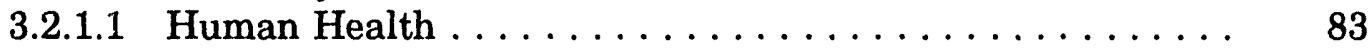

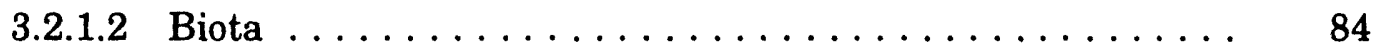

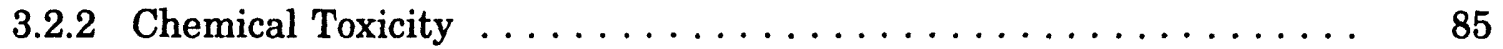

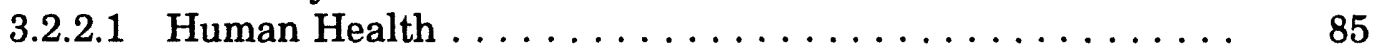

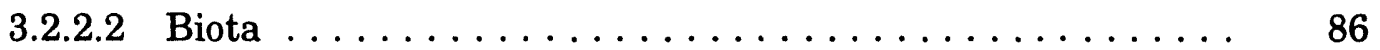

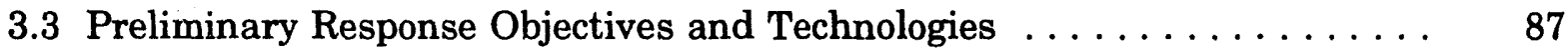

3.4 Conceptual Remedial Action Alternatives $\ldots \ldots \ldots \ldots \ldots \ldots \ldots$

3.5 Data Gaps . . . . . . . . . . . . . . . . . . . . . . . . . . 94

3.5.1 Radioactive and Chemical Contaminants .............. 95

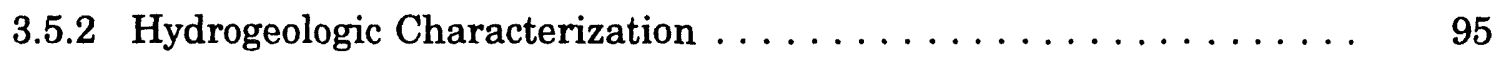

3.5.3 Ecological Resources . . . . . . . . . . . . . . . . . . 97

3.6 Preliminary Identification of Regulatory Requirements . . . . . . . . . . . 99

4 WORK PLAN RATIONALE $\ldots \ldots \ldots \ldots \ldots \ldots \ldots \ldots \ldots \ldots$

4.1 Data Quality Objectives . . . . . . . . . . . . . . . . . . . . 101

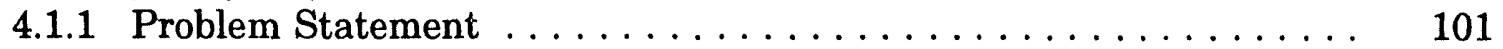

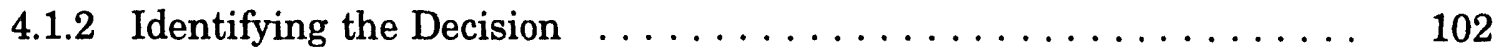

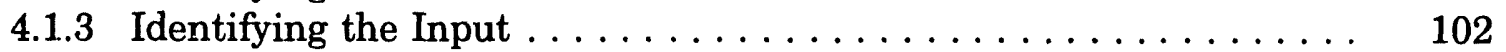

4.1.4 Defining the Domain of the Decision ................ 103

4.1 .5 Decision Rule ........................... 104

4.1.6 Developing Uncertainty Constraints ................ 105

4.1 .7 Optimizing the Sampling Design . . . . . . . . . . . . . . 106

4.2 Data Requirements . . . . . . . . . . . . . . . . . . . 106 


\section{CONTENTS (Cont.)}

4.3 Summary of Quarry Residuals Sampling Plan $\ldots \ldots \ldots \ldots \ldots \ldots .106$

4.3.1 Hydrogeological Investigation $\ldots \ldots \ldots \ldots \ldots \ldots \ldots \ldots .106$

4.3.2 Contaminant Sampling . . . . . . . . . . . . . . . 107

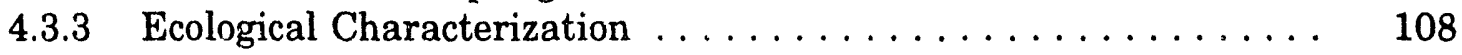

4.4 Summary of Other Supporting Documents $\ldots \ldots \ldots \ldots \ldots \ldots \ldots .109$

4.4.1 Community Relations Plan . . . . . . . . . . . . . . . 109

4.4.2 Health and Safety Plans $\ldots \ldots \ldots \ldots \ldots \ldots \ldots \ldots \ldots .110$

4.4.3 Environmental Quality Assurance Project Plan .......... 110

$5 \quad$ REMEDIAL INVESTIGATION/FEASIBILITY STUDY TASKS $\ldots \ldots \ldots \ldots 112$

5.1 Task 1: Project Planning . . . . . . . . . . . . . . . . . . 112

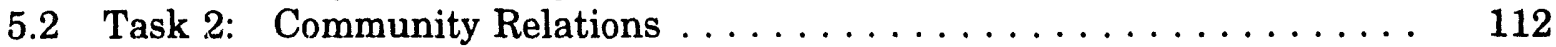

5.3 Task 3: Field Investigation $\ldots \ldots \ldots \ldots \ldots \ldots \ldots \ldots \ldots \ldots, 114$

5.4 Task 4: Sample Analysis and Verification . . . . . . . . . . . 114

5.5 Task 5: Data Evaluation ........................ 115

5.6 Task 6: Risk Assessment $\ldots \ldots \ldots \ldots \ldots \ldots \ldots \ldots \ldots \ldots . \ldots \ldots$

5.7 Task 7: Treatability Studies $\ldots \ldots \ldots \ldots \ldots \ldots \ldots \ldots \ldots \ldots . \ldots \ldots$

5.8 Task 8: Remedial Investigation Report ................... 116

5.9 Task 9: Remedial Alternatives Development and Screening . . . . . . . 117

5.10 Task 10: Detailed Analysis of Alternatives . . . . . . . . . . . . 117

5.11 Task 11: Feasibility Study Report . . . . . . . . . . . . . 118

5.12 Task 12: Post-Remedial Investigation/Feasibility Study Support . . . . 118

5.13 Task 13: Enforcement Support ...................... 119

5.14 Task 14: Miscellaneous Support . . . . . . . . . . . . . . . 119

6 PROJECT SCHEDULE $\ldots \ldots \ldots \ldots \ldots \ldots \ldots \ldots \ldots \ldots \ldots \ldots \ldots \ldots \ldots$

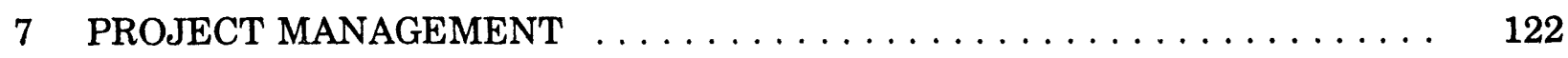

7.1 Project Organization $\ldots \ldots \ldots \ldots \ldots \ldots \ldots \ldots \ldots \ldots \ldots \ldots, 122$

7.2 Project Coordination and Responsibilities ............... 122

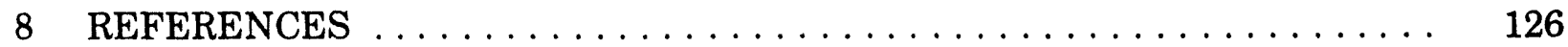

APPENDIX: Derivation of Risk-Based Soil and Water Concentrations . . . . . 137

\section{FIGURES}

1 Location of the Weldon Spring Site $\ldots \ldots \ldots \ldots \ldots \ldots \ldots \ldots \ldots \ldots$

2 Components of Site Remediation $\ldots \ldots \ldots \ldots \ldots \ldots \ldots \ldots \ldots \ldots$

$3 \quad$ Area near the Weldon Spring Quarry $\ldots \ldots \ldots \ldots \ldots \ldots \ldots \ldots .9$ 


\section{FIGURES (Cont.)}

4 Geologic Cross Section Locations for the Weldon Spring Quarry . . . . . . . 16

5 Geologic Cross Section A across the Quarry $\ldots \ldots \ldots \ldots \ldots \ldots \ldots$

6 Geologic Cross Section D Parallel to the Slough $\ldots \ldots \ldots \ldots \ldots$

7 Geologic Cross Section B across the Quarry $\ldots \ldots \ldots \ldots \ldots$

8 Geologic Cross Section $\mathrm{C}$ across the Quarry $\ldots \ldots \ldots \ldots \ldots$

9 Map of the Shallow Water Table Surface Contoured from Average

Water Level Measurements for 1986 through $1992 \ldots \ldots \ldots$. . . . . . . . . 22

10 Locations of Vicinity Properties 6,8 , and $9 \ldots \ldots \ldots \ldots$

11 Surface Water Monitoring Locations . . . . . . . . . . . . . . . 43

12 Locations of Monitoring Wells in the Quarry Area . . . . . . . . . . . . 49

13 Locations of Production Wells in the St. Charles County Well Field . . . . . 50

14 Conceptual Site Model for the Quarry Residuals Operable Unit . . . . . . . 67

15 Uranium-238 Radioactive Decay Series $\ldots \ldots \ldots \ldots \ldots \ldots$

16 Thorium-232 Radioactive Decay Series $\ldots \ldots \ldots \ldots \ldots \ldots \ldots \ldots \ldots$

17 Uranium-235 Radioactive Decay Series $\ldots \ldots \ldots \ldots \ldots \ldots \ldots \ldots$

18 Conceptual Contaminant Food Chain Pathways for Terrestrial

Biota: Vegetation to Avifauna Consumers . . . . . . . . . . . . 80

19 Summary Diagram of the RIFS Process $\ldots \ldots \ldots \ldots \ldots \ldots$

20 RIFS-EA Schedule for the Quarry Residuals Operable Unit . . . . . . . . . 121

21 Project Management Structure $\ldots \ldots \ldots \ldots \ldots \ldots \ldots \ldots \ldots \ldots$

\section{TABLES}

1 Stratigraphy and Hydrostratigraphy of the Weldon Spring Area . . . . . . .

$2 \quad$ Hydraulic Properties Estimated from Aquifer Tests Performed in the Fractured Limestone and in the Alluvium South

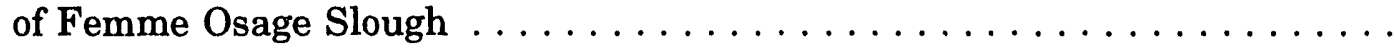




\section{TABLES (Cont.)}

3 Threatened, Endangered, or Special Concern Species Reported

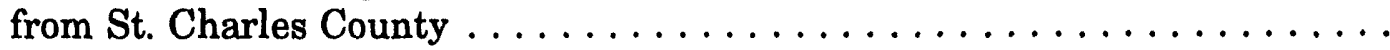

4 Summary of Data Collection Activities at the Weldon Spring Quarry and Vicinity ........................ 31

$5 \quad$ History of Disposal Activities at the Weldon Spring Quarry . . . . . . . 38

6 Summary of Soil Characterization Data for Vicinity Property $9 \ldots \ldots$

7 Summary of Surface Water Data $\ldots \ldots \ldots \ldots \ldots \ldots \ldots$

8 Summary of Sediment Data $\ldots \ldots \ldots \ldots \ldots \ldots \ldots \ldots \ldots$

9 Monitoring Wells for the Quarry Area and the St. Charles County Well Field .......................... 52

10 Summary of Groundwater Data for the Bedrock . . . . . . . . . . . 55

11 Summary of Groundwater Data for the Alluvium . . . . . . . . . . . 57

12 Summary of Background Groundwater Concentrations

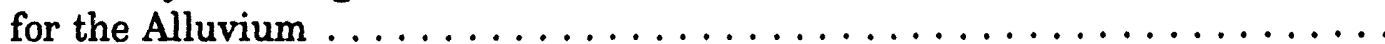

13 Comparison of Groundwater Contaminant Concentrations with Regulatory Standards . . . . . . . . . . . . . . . . . .

14 Activity Concentration Ratios Estimated for the Major Radionuclides in Quarry Soil $\ldots \ldots \ldots \ldots$

15 Examples of Assessment and Measurement End Points for the Ecological Assessments in the Quarry Residuals Operable Unit . . . . . . . .

16 General Response Actions and Technologies . . . . . . . . . . . . . . . 90

17 Examples of Possible Tests and Surveys for the Ecological Assessment of the Quarry Residuals Operable Unit

18 Key Environmental Requirements and Guidelines Potentially

Considered for the Final Quarry Response . . . . . . . . . . . . . . . . . . . . 100

A.1 Exposure Scenario Assumptions and Intake Parameters . . . . . . . . . . . 142

A.2 Soil and Water Concentrations of Radionuclides Associated with Target Risk Levels . . . . . . . . . . . . . . . . . . . . . . . . . . 


\section{TABLES (Cont.)}

A.3 Soil and Water Concentrations of Chemicals Associated

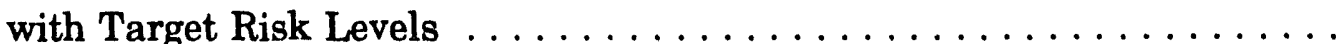

A.4 Soil and Water Concentrations of Chemicals Associated with Target Hazard Quotients . . . . . . . . . . . . . . . . . 145 


\section{NOTATION}

The following is a list of the acronyms, initialisms, and abbreviations (including units of measure) used in this document. Acronyms used in tables only are defined in the respective tables.

\section{ACRONYMS, INITIALISMS, AND ABBREVIATIONS}

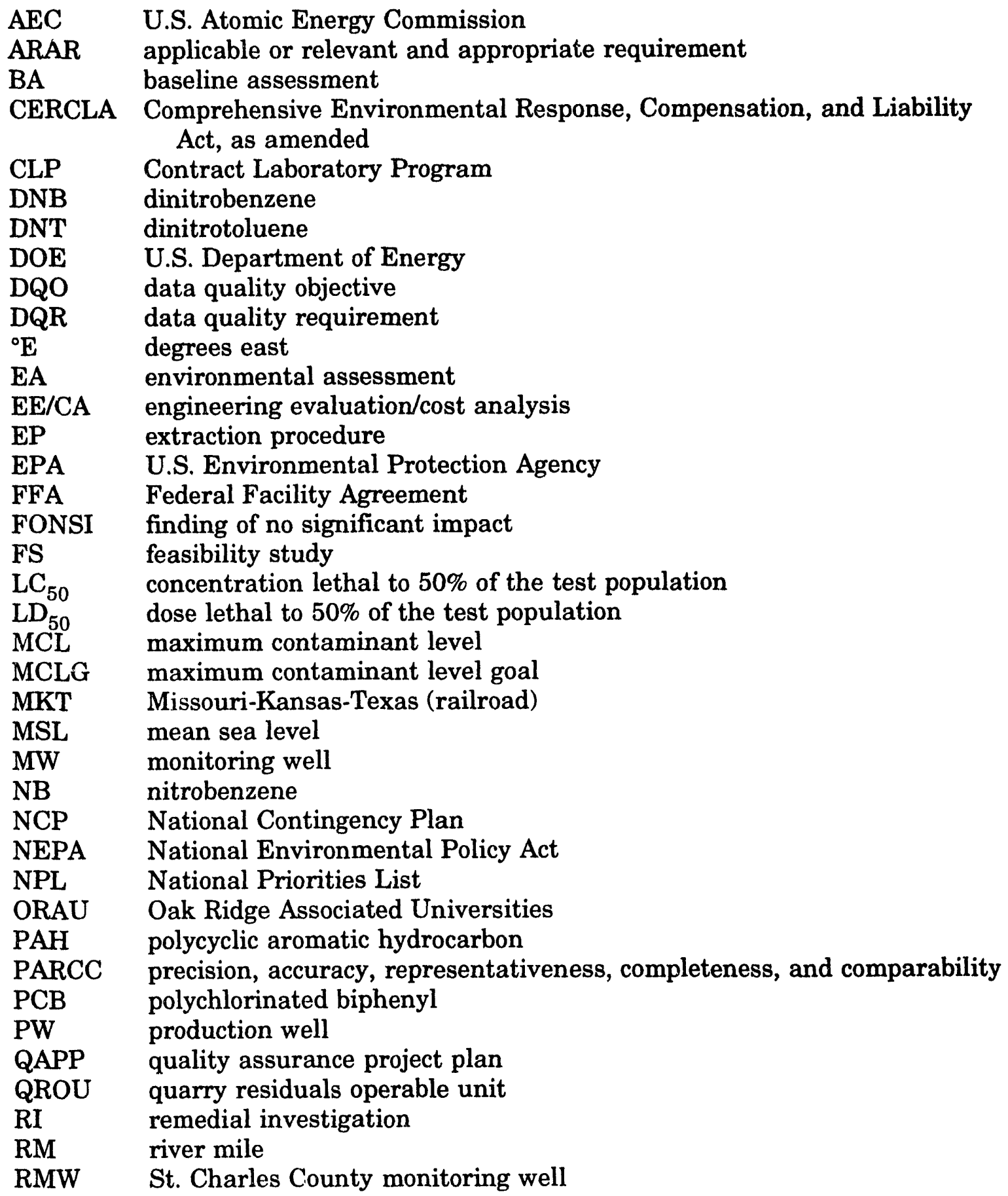




\section{NOTATION (Cont.)}

ROD record of decision

SARA Superfund Amendments and Reauthorization Act

SMCL secondary maximum contaminant level

SOP standard operating procedure

TBC to-be-considered (requirement)

TNB trinitrobenzene

TNT trinitrotoluene

USGS U.S. Geological Survey

VOC volatile organic compound

${ }^{\circ} \mathrm{W}$ degrees west

\section{UNITS OF MEASURE}

$\begin{array}{ll}{ }^{\circ} \mathrm{C} & \text { degree(s) Celsius } \\ { }^{\circ} \mathrm{F} & \text { degree(s) Fahrenheit } \\ \mathrm{cm} & \text { centimeter(s) } \\ \mathrm{d} & \text { day(s) } \\ \mathrm{ft} & \text { foot (feet) } \\ \mathrm{ft}^{2} & \text { square foot (feet) } \\ \mathrm{g} & \text { gram(s) } \\ \mathrm{gal} & \text { gallon(s) } \\ \mathrm{h} & \text { hour(s) } \\ \mathrm{ha} & \text { hectare(s) } \\ \text { in. } & \text { inch(es) } \\ \mathrm{kg} & \text { kilogram(s) } \\ \mathrm{km} & \text { kilometer(s) } \\ \mathrm{I} & \operatorname{liter}(\mathrm{s}) \\ \mathbf{\mu g} & \text { microgram(s) }\end{array}$

$\begin{array}{ll}\mathrm{m}^{2} & \text { meter(s) } \\ \mathrm{m}^{2} & \text { square meter(s) } \\ \mathrm{m}^{3} & \text { cubic meter(s) } \\ \mathbf{m g} & \text { milligram(s) } \\ \mathbf{m i} & \text { mile(s) } \\ \mathbf{m p h} & \text { mile(s) per hour } \\ \mathbf{m r e m} & \text { millirem(s) } \\ \mathrm{pCi} & \text { picocurie(s) } \\ \mathbf{r a d} & \text { radiation adsorbed dose } \\ \mathrm{rem} & \text { roentgen equivalent man } \\ \mathrm{s} & \text { second(s) } \\ \mathrm{t} & \text { metric ton(s) } \\ \mathrm{yd} & \text { cubic yard(s) } \\ \mathrm{yr} & \text { year(s) }\end{array}$




\section{ENGLISH/METRIC AND METRIC/ENGLISH EQUTVALENTS}

In this document, units of measure are presented with the metric equivalent first, followed by the measured English unit in parentheses. In cases where the measurement was originally made in metric units, the values were not converted back to English units; in tables, the data are generally in English or metric units only. The following table lists the appropriate equivalents for English and metric units.

\begin{tabular}{|c|c|c|}
\hline Multiply & By & To Obtain \\
\hline \multicolumn{3}{|l|}{ English/Metric Equivalents } \\
\hline $\begin{array}{l}\text { acres } \\
\text { cubic feet }\left(\mathrm{ft}^{3}\right) \\
\text { cubic yards }\left(\mathrm{yd}^{3}\right) \\
\text { degrees Fahrenheit }\left({ }^{\circ} \mathrm{F}\right)-32 \\
\text { feet (ft) } \\
\text { gallons (gal) } \\
\text { gallons (gal) } \\
\text { inches (in.) } \\
\text { miles (mi) } \\
\text { pounds (lb) } \\
\text { short tons (tons) } \\
\text { short tons (tons) } \\
\text { square feet }\left(\mathrm{ft}^{2}\right) \\
\text { square yards }\left(\mathrm{yd}^{2}\right) \\
\text { square miles }\left(\mathrm{mi}^{2}\right) \\
\text { yards (yd) }\end{array}$ & $\begin{array}{l}0.4047 \\
0.02832 \\
0.7646 \\
0.5555 \\
0.3048 \\
3.785 \\
0.003785 \\
2.540 \\
1.609 \\
0.4536 \\
907.2 \\
0.9072 \\
0.09290 \\
0.8361 \\
2.590 \\
0.9144\end{array}$ & $\begin{array}{l}\text { hectares }(\mathrm{ha}) \\
\text { cubic meters }\left(\mathrm{m}^{3}\right) \\
\text { cubic meters }\left(\mathrm{m}^{3}\right) \\
\text { degrees Celsius }\left({ }^{\circ} \mathrm{C}\right) \\
\text { meters }(\mathrm{m}) \\
\text { liters }(\mathrm{L}) \\
\text { cubic meters }\left(\mathrm{m}^{3}\right) \\
\text { centimeters }(\mathrm{cm}) \\
\text { kilometers }(\mathrm{km}) \\
\text { kilograms }(\mathrm{kg}) \\
\text { kilograms }(\mathrm{kg}) \\
\text { metric tons }(\mathrm{t}) \\
\text { square meters }\left(\mathrm{m}^{2}\right) \\
\text { square meters }\left(\mathrm{m}^{2}\right) \\
\text { square kilometers }\left(\mathrm{km}^{2}\right) \\
\text { meters }(\mathrm{m})\end{array}$ \\
\hline \multicolumn{3}{|l|}{ Metric/English Equivalents } \\
\hline $\begin{array}{l}\text { centimeters }(\mathrm{cm}) \\
\text { cubic meters }\left(\mathrm{m}^{3}\right) \\
\text { cubic meters }\left(\mathrm{m}^{3}\right) \\
\text { cubic meters }\left(\mathrm{m}^{3}\right) \\
\text { degrees Celsius }\left({ }^{\circ} \mathrm{C}\right)+17.78 \\
\text { hectares }(\mathrm{ha}) \\
\text { kilograms }(\mathrm{kg}) \\
\text { kilograms }(\mathrm{kg}) \\
\text { kilometers }(\mathrm{km}) \\
\text { liters }(\mathrm{L}) \\
\text { meters }(\mathrm{m}) \\
\text { meters }(\mathrm{m}) \\
\text { metric tons }(\mathrm{t}) \\
\text { square kilometers }\left(\mathrm{km}^{2}\right) \\
\text { square meters }\left(\mathrm{m}^{2}\right) \\
\text { square meters }\left(\mathrm{m}^{2}\right)\end{array}$ & $\begin{array}{l}0.3937 \\
35.31 \\
1.308 \\
2.64 .2 \\
1.8 \\
2.471 \\
2.205 \\
0.001102 \\
0.6214 \\
0.2642 \\
3.281 \\
1.094 \\
1.102 \\
0.3861 \\
10.76 \\
1.196\end{array}$ & $\begin{array}{l}\text { inches (in.) } \\
\text { cubic feet }\left(\mathrm{ft}^{3}\right) \\
\text { cubic yards }\left(\mathrm{yd}^{3}\right) \\
\text { gallons (gal) } \\
\text { degrees Fahrenheit }\left({ }^{\circ} \mathrm{F}\right) \\
\text { acres } \\
\text { pounds (lb) } \\
\text { short tons (tons) } \\
\text { miles (mi) } \\
\text { gallons (gal) } \\
\text { feet (ft) } \\
\text { yards (yd) } \\
\text { short tons (tons) } \\
\text { square miles }\left(\mathrm{mi}^{2}\right) \\
\text { square feet }\left(\mathrm{ft}^{2}\right) \\
\text { square yards }\left(\mathrm{yd}^{2}\right)\end{array}$ \\
\hline
\end{tabular}




\section{INTRODUCTION}

The U.S. Department of Energy (DOE) is conducting cleanup activities at the Weldon Spring site, which is located in St. Charles County, Missouri, about $48 \mathrm{~km}$ (30 mi) west of St. Louis (Figure 1). The Weldon Spring site consists of two noncontiguous areas - the chemical plant area, which includes four raffinate pits, and the quarry. Cleanup activities at the Weldon Spring site are conducted in accordance with the Comprehensive Environmental Response, Compensation, and Liability Act (CERCLA), as amended, incorporating the values of the National Environmental Policy Act (NEPA). Values of NEPA relate to the significance of environmental resources. Incorporating these values into the CERCLA process for the Weldon Spring project ensures that potential impacts to these resources are considered as part of planning and decision making for site cleanup. The contents of the documents prepared for the project are not intended to represent a statement regarding the legal applicability of NEPA to remedial actions conducted under CERCLA.

In accordance with the integrated CERCLA/NEPA approach, a remedial investigation/feasibility study-environmental assessment (RI/FS-EA) is being conducted to evaluate conditions and potential responses for the quarry residuals operable unit (QROU). This operable unit consists of the following areas and/or media: (1) the residual material remaining at the Weldon Spring quarry after removal of the pond water and bulk waste; (2) underlying groundwater; and (3) other media located in the surrounding vicinity of the quarry, including adjacent soil, surface water, and sediment in Femme Osage Slough.

An overall strategy for remediation to address contamination at the Weldon Spring site has been established (Figure 2). This strategy, which is discussed in environmental documentation previously prepared for the project (DOE 1992d), identified tive distinct components at the quarry area that require evaluation:

- Pond water;

- Bulk waste;

- Residual material;

- Underlying groundwater; and

- Vicinity soil, surface water, and sediment.

Previous documentation has been prepared to address the pond water and bulk waste. An engineering evaluation/cost analysis (EE/CA) report, written to incorporate NEPA values appropriate for an environmental assessment (EA), was prepared to support management of the pond water (MacDonell et al. 1989). A focused RI/FS package, written to incorporate NEPA values appropriate for an EA, was prepared to support management or removal of the bulk waste (DOE 1990a, 1990b, 1990c, 1990d). The water treatment plant built to process 


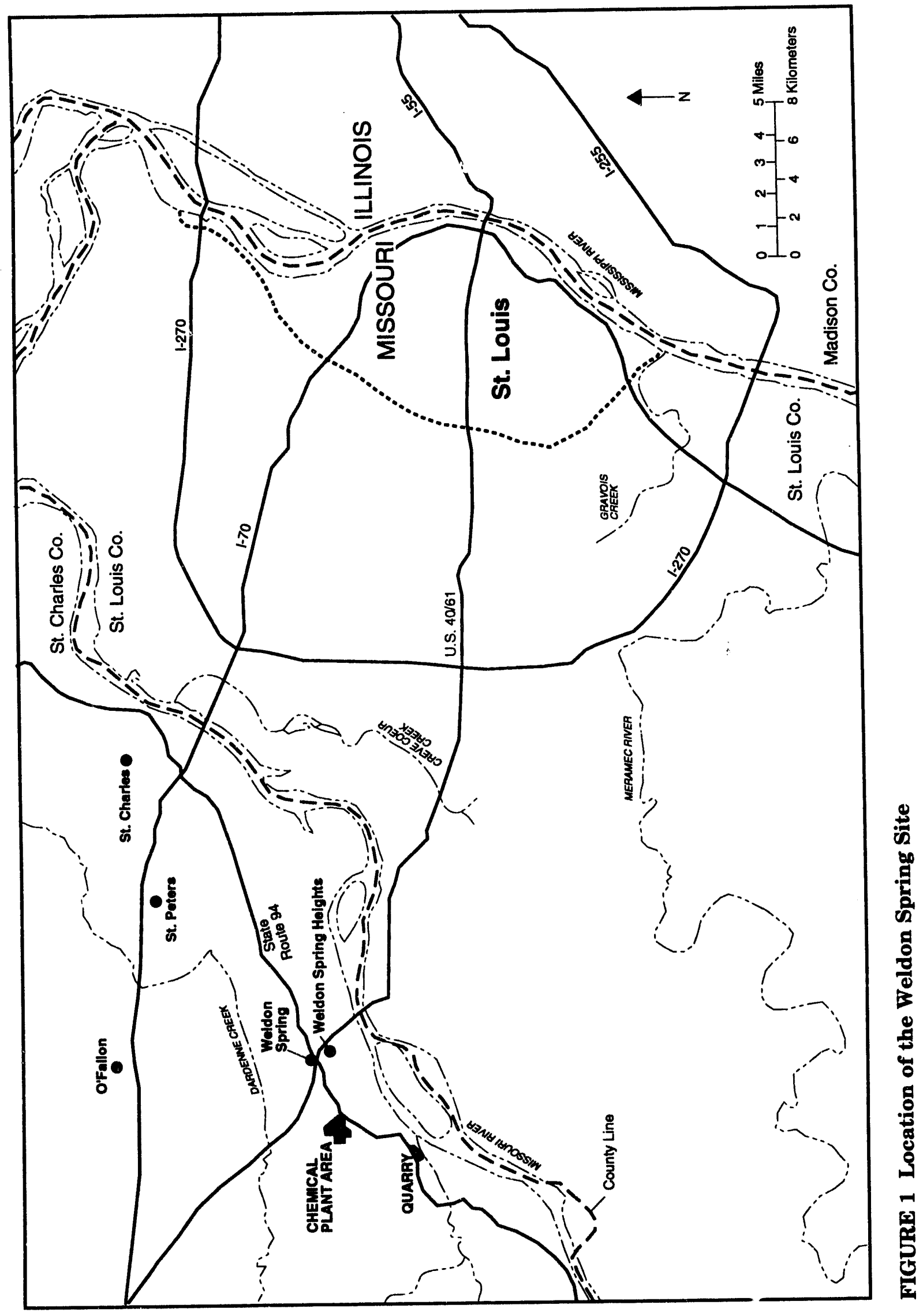




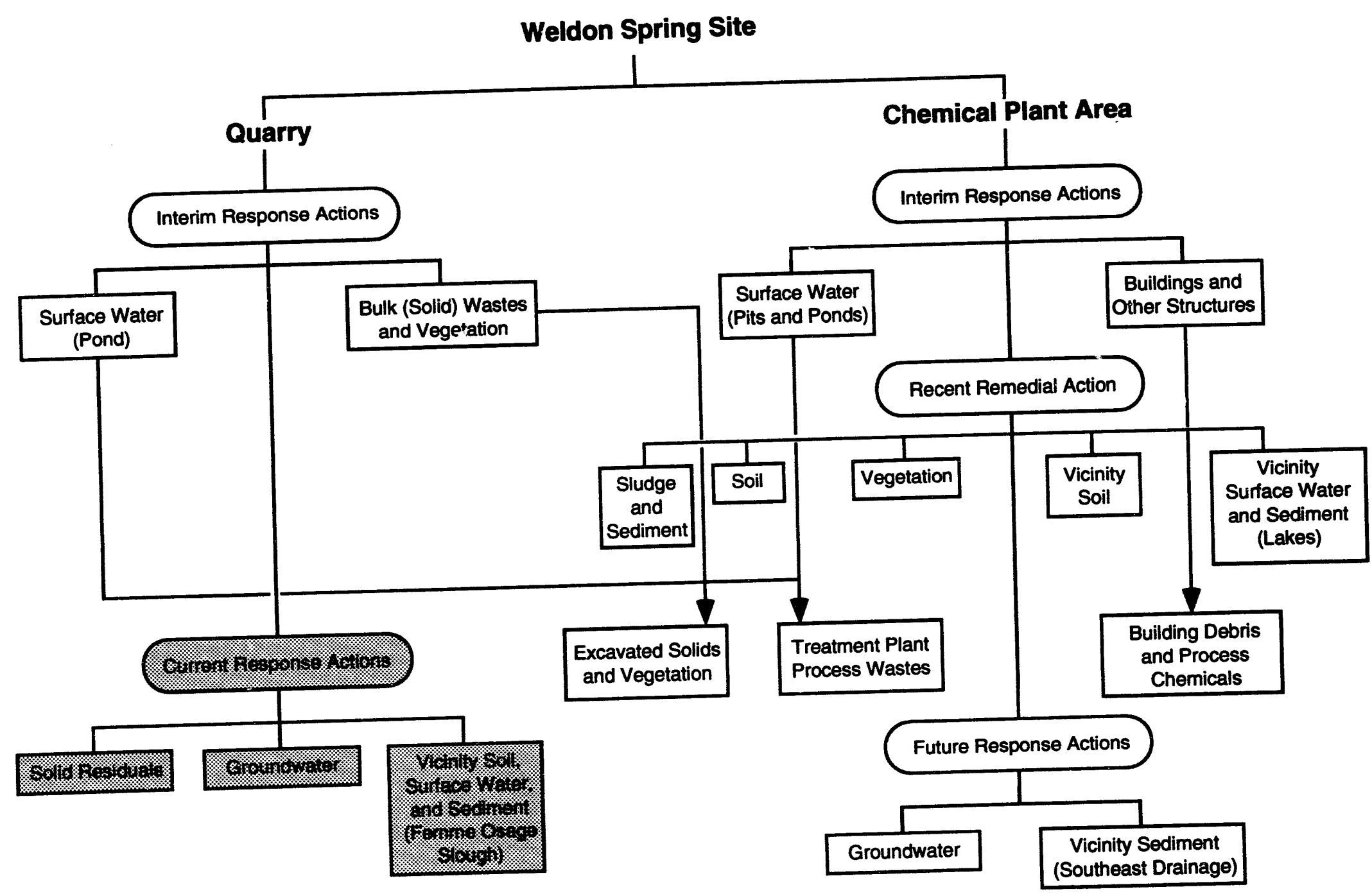

$\omega$ Note: The boxes represent contaminated media addressed by the project's cleanup actions for the chemical plant area and the quarry, and they are connected
to the appropriate phase of site cleanup. The media for which specific decisions will be made as part of the current remedial action are indicated by shading.

FIGURE 2 Components of Site Remediation (Note that the disposition of contaminated material from this action (he recent chemical plant area remedial action.) 
the pond water has recently become operational and will treat water during the quarry cleanup period. Bulk waste excavation is scheduled to start in 1993 and continue for 2 to 3 years. The remaining three components are being addressed within the RI/FS-EA for the QROU, for which this work plan is being prepared.

This work plan identifies the activities within the RI/FS-EA process that are being proposed to address contamination remaining at the quarry area. The overall format of the work plan follows that recommended in U.S. Environmental Protection Agency (EPA) guidance for conducting an RI/FS (EPA 1988). The organization of this work plan is as follows:

- Section 1, this introduction, discusses the objectives for conducting the evaluation, including a brief summary of relevant site information and overall environmental compliance activities to be undertaken.

- Section 2 presents site history and a description of the quarry area, along with currently available data.

- Section 3 presents a preliminary evaluation of the quarry area, which is based on the information given in Section 2, and discusses data gaps.

- Section 4 presents the rationale for data collection or characterization activities to be carried out in the RI phase, along with brief summaries of all supporting documents accompanying this work plan.

- Section 5 discusses the activities planned for the QROU under each of the 14 tasks for the RI/FS-EA.

- Section 6 presents the proposed schedule for the RI/FS-EA for the QROU.

- Section 7 briefly explains the project management structure.

\subsection{GENERAL SITE INFORMATION}

The Weldon Spring quarry is about $6.4 \mathrm{~km}(4 \mathrm{mi})$ south-southwest of the chemical plant area. It is accessible from State Route 94 and is fenced and closed to the public. The quarry is about $300 \mathrm{~m}(1,000 \mathrm{ft})$ long by $140 \mathrm{~m}(450 \mathrm{ft})$ wide and covers an area of approximately 3.6 ha (9 acres). It is vegetated with grasses, shrubs, and trees, and it is surrounded by the Weldon Spring Conservation Area.

The now dismantled Missouri-Kansas-Texas (MKT) railroad line formerly passed just south of the quarry; the right-of-way has been converted to a gravel-based public trail for hiking and biking known as Katy Trail. Immediately south of the Katy Trail is Femme Osage Slough, a nearly stagnant body of water whose elevation fluctuates in response to precipitation and the level of the Missouri River. The St. Charles County well field is located 
southeast of the quarry, between the quarry and the Missouri River. Nearby streams include Little Femme Osage Creek to the west, an unnamed tributary of Little Femme Osage Creek to the north, and Femme Osage Creek to the southwest; all of these streams drain into the Missouri River, which is about $1.6 \mathrm{~km}(1 \mathrm{mi})$ southeast of the quarry. Although most of the land surrounding the quarry is wooded and protected as a conservation area, the land between the quarry and the river is generally agricultural.

\subsection{JUSTIFICATION AND OBJECTIVES FOR THE PROPOSED ACTION}

The primary threat to human health and the environment associated with contamination at the quarry area is the potential for uncontrolled release of contaminants from exposed surface areas and the dispersion of contaminants via leaching into the underlying groundwater. Therefore, remedial action is being proposed for the QROU to eliminate, reduce, or otherwise mitigate the potential for exposure to radioactive and chemical contaminants. Specific activities that will be conducted to support the determination of an appropriate remedial action are as follows:

- Characterize contamination remaining in the quarry after removal of the pond water and bulk waste;

- Characterize contamination in the surrounding area - including surface water, sediment, groundwater, and soil;

- Evaluate potential impacts to human health and the environment from exposure to contaminants; and

- Evaluate potential remedial action alternatives.

All activities will be conducted in accordance with CERCLA, NEPA, and applicable environmental requirements.

\subsection{ENVIRONMENTAL COMPLIANCE PROCESS}

Remedial actions at the Weldon Spring site, including the proposed actions at the QROU, are conducted in a manner that integrates NEPA values and CERCLA procedural and documentational requirements. The RI/FS conducted under CERCLA is the primary process for environmental compliance associated with remedial actions at the Weldon Spring site. Under the integrated approach followe! by DOE for the site, the CERCLA process is supplemented, as appropriate, to incorporate the values of NEPA. A key element of the integrated CERCLA/NEPA process is the determination of the level of environmental analysis appropriate under NEPA. This determination is a function of many factors, including the complexity of a proposed action, the likelihood for significant environmental impacts, and the potential for considerable public interest. On the basis of the current understanding of the QROU, an EA is expected to be the appropriate level of NEPA compliance. That is, no significant impacts to the environment are expected to occur on the basis of the scope of 
remedial activities that may be required. The DOE expects to complete this determination at the time the preliminary alternatives for this remedial action are screened in the FS that will be prepared within the next several years.

Within the framework and time period of the RI/FS-EA process for the QROU, several potential interim response actions may be undertaken, as appropriate, to mitigate any potential threats resulting from contamination present in discrete portions of the quarry area. For example, to mitigate a source of contamination to the underlying groundwater, soil contamination present in the parcel of land south of the quarry and north of Femme Osage Slough could be addressed by an EE/CA, incorporating appropriate NEPA values; potential contamination at Femme Osage Slough could be addressed in a similar manner. In addition, a treatability study is planned to determine the feasibility of removing and treating the underlying groundwater. If this option proves viable, an EE/CA may also be prepared to support a removal action for groundwater; this EE/CA would also incorporate appropriate NEPA values. Any solid waste material generated from interim response actions for the QROU would be consolidated and handled, as appropriate, in accordance with the record of decision (ROD) for the chemical plant area of the Weldon Spring site.

\subsection{EXTERNAL INVOLVEMENT}

Activities related to the QROU are coordinated with the EPA, state agencies, and the general public. The respective roles of these participants and the coordination of activities are discussed in Sections 1.4.1 through 1.4.3.

\subsubsection{Coordination with Other Agencies}

The DOE, under Executive Order 12580, has the authority to conduct remedial action at sites under its control. As the lead agency, DOE conducts remedial action activities at the Weldon Spring site in coordination with EPA Region VII and the state of Missouri. A Federal Facility Agreement (FFA), detailing DOE's compliance activities and EPA's oversight responsibilities, has been negotiated as required by Section 120 of CERCLA. Highlights of this FFA are summarized in Section 1.4.2.

Plans and activities at the QROU are also being coordinated with appropriate state agencies, including the Missouri Department of Natural Resources and the Missouri Department of Conservation.

\subsubsection{Summary of the Federal Facility Agreement}

The original FFA was signed by DOE and EPA in 1986 but has been substantially modified. An amended FFA, which is currently in place for the project, includes stipulations applicable to the QROU. This FFA includes agreements to ensure that the environmental impacts associated with past and present activities at the quarry area are thoroughly investigated and that appropriate remedial action is taken, as necessary, to protect public 
health and welfare and the environment. The FFA also establishes a procedural framework and schedule for developing, implementing, and monitoring appropriate response actions at the quarry area in accordance with CERCLA (as amended by the Superfund Amendments and Reauthorization Act [SARA]), the National Contingency Plan (NCP), and applicable or relevant and appropriate state laws. This FFA also facilitates the exchange of information between the EPA, DOE, and the state of Missouri and contains procedures for resolving disputes, assigning penalties for nonconformance, and ensuring public participation in the remedial action decision-making process.

As stipulated in the FFA, DOE will prepare and transmit drafts of the primary documents associated with remedial action planning, decision making, and design and construction to the EPA and the Missouri Department of Natural Resources for review and comment. The primary documents associated with the RI/FS-EA for this operable unit that require approval by EPA are as follows: the work plan, including sampling and analysis plans; the baseline risk assessment; the remedial investigation (RI); the feasibility study (FS); the proposed plan; and the ROD. Secondary documents that are specified in the FFA for transmittal to the EPA for review and comment include the preliminary analysis of alternatives, any required post-screening investigation work plans or reports, the predecision work plan, treatability studies, and the remedial decision quality assurance project plan (QAPP). A draft FFA implementation plan has been prepared to ensure compliance and fill any gaps in the agreement.

The current FFA also specifies that a progress report be submitted quarterly to the EPA detailing major accomplishments, issues, and milestones. The report describes the status of data collection, environmental documentation, engineering, construction, and procurement. The previous quarter's progress, current status, and next quarter's planned activities are included for each operable unit.

\subsubsection{Public Participation}

The DOE is committed to a program of public participation as part of the remedial action process. A formal community relations program for the site is in place to gather information from the community, inform the public of ongoing and planned activities, and facilitate public input to remedial action decisions. Through this program, the DOE interacts with the public by such means as news releases, public meetings, discussions with local interest groups, receipt of and response to public comments, and maintenance of the public repository for documents and information related to the site and its cleanup. The community relations plan for the Weldon Spring site is discussed in Section 4. 


\section{SITE BACKGROUND AND SETTING}

\subsection{SITE DESCRIPTION}

The Weldon Spring quarry is located in St. Charles County, Missouri, about $8 \mathrm{~km}$ (5 mi) southwest of the city of Weldon Spring and $48 \mathrm{~km}(30 \mathrm{mi})$ west of the city of St. Louis (Figure 1). The quarry is about $6.4 \mathrm{~km}(4 \mathrm{mi})$ south-southwest of the chemical plant area. The quarry is accessible from State Route 94 and is fenced and closed to the public.

The quarry was excavated into a limestone bluff that forms a valley wall at the edge of the Missouri River alluvial floodplain; prior to 1942, it was mined for limestone to support various construction activities. The quarry is about $300 \mathrm{~m}(1,000 \mathrm{ft})$ long by $140 \mathrm{~m}(450 \mathrm{ft})$ wide and covers an area of approximately $3.6 \mathrm{ha}(9 \mathrm{acres})$. The main floor of the quarry comprises about $0.8 \mathrm{ha}$ ( 2 acres); an estimated $73,000 \mathrm{~m}^{3}\left(95,000 \mathrm{yd}^{3}\right)$ of contaminated bulk waste has been deposited in the quarry since the 1940s (DOE 1989). Prior to the initiation of dewatering in 1992, the quarry pond contained about $11,000 \mathrm{~m}^{3}(3,000,000 \mathrm{gal})$ of pond water covering $0.2 \mathrm{ha}(0.5 \mathrm{acre})$. The quarry pond has an average surface elevation of about

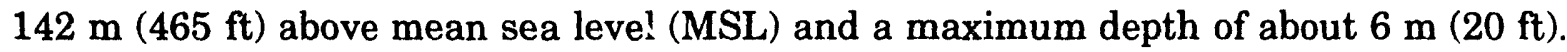

The quarry is surrounded by the Weldon Spring Conservation Area. The MKT railroad line formerly passed just south of the quarry; this line was dismantled, and the right-of-way has been converted to a gravel-based public trail for recreational activities (Katy Trail, also known as the Missouri River Trail). The St. Charles County well field is located southeast of the quarry between Femme Osage Slough and the Missouri River; the closest well is approximately $0.8 \mathrm{~km}(0.5 \mathrm{mi})$ from the quarry. The well field is a major source of potable water for St. Charles County, and the well field area is actively farmed. The area around the quarry is shown in Figure 3.

\subsection{SITE HISTORY}

In April 1941, the U.S. Department of the Army acquired about 7,000 ha (17,000 acres) of land in St. Charles County, Missouri, to construct and operate the Weldon Spring Ordnance Works. From November 1941 through January 1944, the Atlas Powder Company operated the ordnance works for the Army to produce trinitrotoluene (TNT) and dinitrotoluene (DNT) explosives. The ordnance works was reopened during 1945 and 1946 but was closed and declared surplus to Army needs in April 1946. By 1949, all but about 810 ha (2,000 acres) had been transferred to the state of Missouri (August A. Busch Memorial Conservation Area) and the University of Missouri (agricultural land). Much of the land transferred to the University of Missouri was subsequently developed into the Weldon Spring Conservation Area. Except for several small parcels transferred to St. Charles County, the remaining property became the current chemical plant area and the U.S. Army Reserve and National Guard Training Area. 


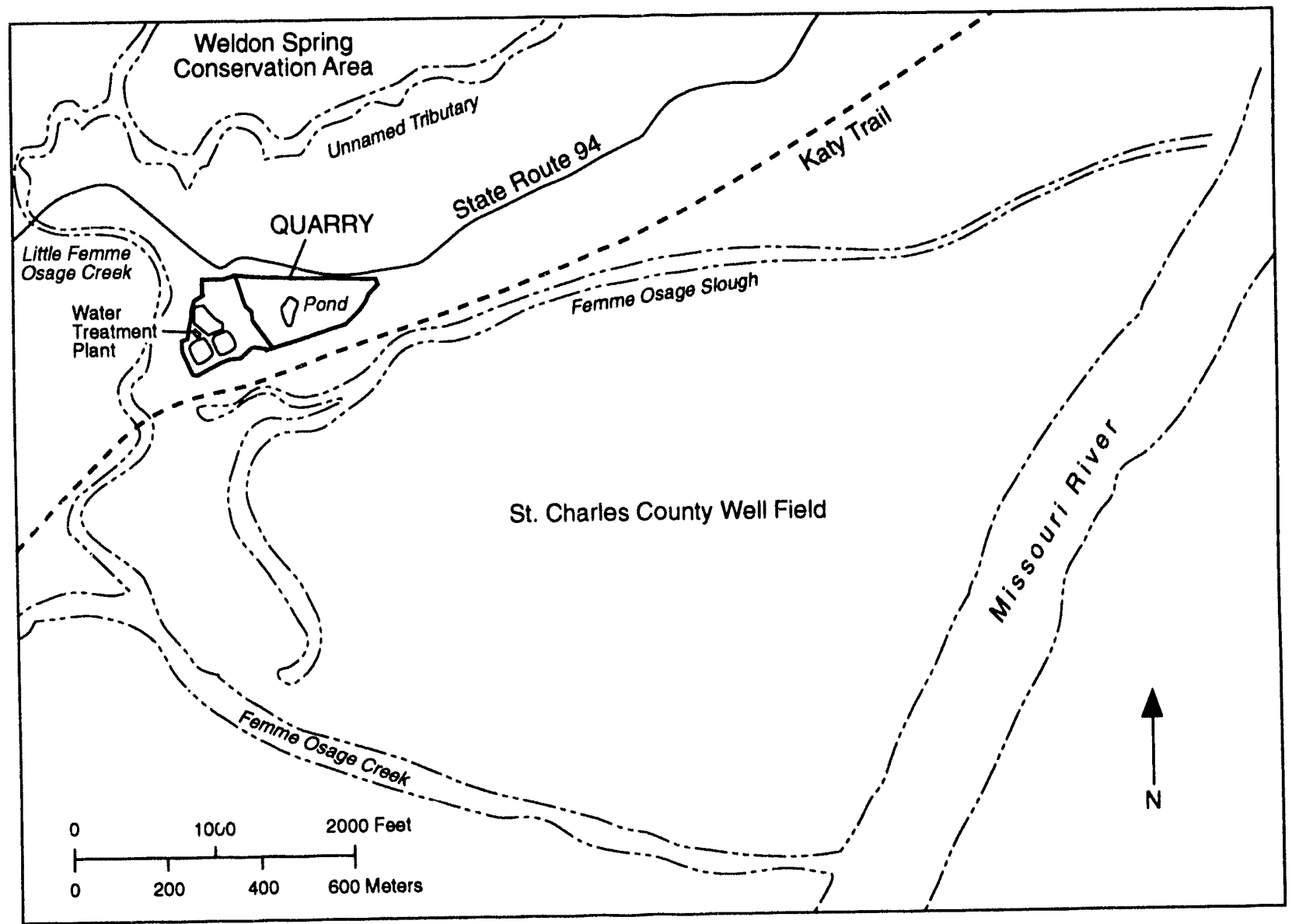

FIGURE 3 Area near the Weldon Spring Quarry

The U.S. Atomic Energy Commission (AEC, a predecessor of DOE) acquired 83 ha (205 acres) of the former ordnance works property from the Army by permit in May 1955, and the property transfer was approved by Congress in August 1956. An additional 6 ha (15 acres) was later transferred to the AEC for expansion of waste storage capacity; the AEC also constructed a feed materials plant - now referred to as the chemical plant - for the purpose of processing uranium and thorium ore concentrates. The quarry, which had been used by the Army since the early 1940s for disposal of chemically contaminated (explosive) materials, was transferred to the AEC in July 1960 for use as a disposal site for radioactively contaminated materials (Niedermeyer 1976).

The chemical plant was operated for the AEC by the Uranium Division of Mallinckrodt Chemical Works from 1957 to 1966. During this period, the AEC used the quarry to dispose of uranium and thorium residues (drummed and uncontained), radioactively contaminated building rubble and process equipment, and TNT and DNT residues from cleanup of the former ordnance works. Following closure by the AEC, the Army reacquired the chemical plant site in 1967 and began converting the facility for herbicide production. The buildings were partially decontaminated, and some equipment was dismantled. Contaminated rubble and equipment from some buildings was placed in the quarry; a small 
amount was also placed in raffinate pit 4. In 1969, prior to becoming operational, the herbicide project was canceled. Since that time, the plant has remained essentially unused and in caretaker status.

In 1971, the Army returned the 21-ha (51-acre) portion of the property containing the raffinate pits to the AEC but retained control of the rest of the chemical plant area. As successor to the AEC, DOE assumed responsibility for the raffinate pits. During 1984, the Army repaired several of the buildings; decontaminated some of the floors, walls, and ceilings; and removed some contaminated equipment to areas outside of the buildings. In May 1985, DOE designated the control and decontamination of the Weldon Spring site as a Major Project; it was redesignated as a Major System Acquisition in May 1988. A project office was established in October 1986, and the site is currently under the control of DOE and is managed by DOE's project management contractor, MK-Ferguson Company.

In October 1985, the EPA proposed to list the Weldon Spring quarry on the National Priorities List (NPL); this listing occurred in July 1987 (EPA 1987). In June 1988, the EPA proposed to expand the listing to include the chemical plant area; this listing occurred in March 1989 (EPA 1989a). The balance of the former Weldon Spring Ordnance Works property, which was contaminated by Army activities and for which the Army has responsibility, was proposed for a separate NPL listing in July 1989; this listing was finalized in February 1990 (EPA 1990b).

The quarry pond acts as a source of contamination to groundwater in the underlying aquifer because the pond surface is higher than the nearby groundwater table and the groundwater gradient is to the south/southeast. To mitigate the potential threat to the nearby drinking water supply in the St. Charles County well field, two separate response actions have been approved: management of the contaminated pond water in the quarry and removal of the bulk waste. An EE/CA was prepared to support the decision to treat pond water in a facility constructed adjacent to the quarry and to release the treated water into the Missouri River (MacDonell et al. 1989). A NEPA finding of no significant impact (FONSI) was issued in February 1990, and the water treatment plant became operational in 1992. A focused RI/FS-EA package was prepared to support removal of the bulk waste from the quarry (DOE 1989, 1990a, 1990b, 1990c, 1990d). The DOE issued a NEPA FONSI in November 1990 and a CERCLA ROD in March 1991; excavation of the bulk waste is expected to begin in 1993 and continue over a 2- to 3-year period.

\subsection{ENVIRONMENTAL SETTING}

\subsubsection{Climate}

The Weldon Spring quarry area has a modified continental climate that is characterized by moderately cold winters and warm summers. The area is in the path of cold air moving south from Canada, warm and moist air moving north from the Gulf of Mexico, and dry air moving in from the west. The alternate incursion of these air masses over the site 
and the conflict along the frontal zones result in a wide spectrum of weather conditions, none of which typically persists for a prolonged period of time (Bair 1992). Site-specific meteorological data for the quarry area are not available, and such data at nearby locations (e.g., Weldon Spring chemical plant and Labadie Power Plant) are limited to a short period of record. Thus, the climatic conditions at the quarry area are represented by data from the Lambert-St. Louis International Airport, which is a second-order National Weather Service station and the closest station to the quarry (about $32 \mathrm{~km}$ [20 mi] east-northeast of the site).

For the period $1951-1980$, the annual average temperature was $13.0^{\circ} \mathrm{C}\left(55.4^{\circ} \mathrm{F}\right)$; the average daily maximum and minimum temperatures were $31.7^{\circ} \mathrm{C}\left(89.0^{\circ} \mathrm{F}\right)$ in July and $-6.7^{\circ} \mathrm{C}$ $\left(19.9^{\circ} \mathrm{F}\right)$ in January, respectively. Temperature extremes over the period 1958-1989 ranged from $-28^{\circ} \mathrm{C}\left(-18^{\circ} \mathrm{F}\right)$ to $42^{\circ} \mathrm{C}\left(107^{\circ} \mathrm{F}\right)$; the annual average relative humidities at midnight, 6:00 a.m., noon, and 6:00 p.m. were 77, 83, 59, and 61\%, respectively (Bair 1992).

The prevailing winds in the St. Louis area are from the south, with an average speed of $4.3 \mathrm{~m} / \mathrm{s}(9.7 \mathrm{mph})$. Winds occur most often from the south at an average speed of $3.9 \mathrm{~m} / \mathrm{s}$ (8.7 $\mathrm{mph}$ ) during May through November, and from the northwest and west-northwest at an average speed of $4.9 \mathrm{~m} / \mathrm{s}(11.0 \mathrm{mph})$ during the remainder of the year. From 1984 to 1989, the peak gust reported was $29.5 \mathrm{~m} / \mathrm{s}$ (66 mph) from the west in March 1984 (Bair 1992).

The normal annual precipitation is $86.1 \mathrm{~cm}$ (33.9 in.). Winter is the driest season, with an average precipitation of $15.4 \mathrm{~cm}$ (6.1 in.); spring is the wettest season, with an average precipitation of $26.3 \mathrm{~cm}$ (10.4 in.). Snow in the region occurs as early as October and as late as June, averaging $50.5 \mathrm{~cm} / \mathrm{yr}$ (19.9 in./yr). However, most snow falls from December through March. The maximum monthly snowfall of $66.8 \mathrm{~cm}$ (26.3 in.) occurred in December 1973 , and the maximum daily snowfall was $35.3 \mathrm{~cm}$ (13.9 in.) in January 1982 . Thunderstorms are frequently associated with summer rains, often accompanied by hail and damaging winds. The average frequency of thunderstorms recorded for the region from 1958 to 1989 was $46.2 \mathrm{~d} / \mathrm{yr}$ (Bair 1992).

Tornadoes may occur in the St. Louis area once or twice per year, most often in April and May, but most have short and narrow paths and usually dissipate after a few kilometers. From 1918 to 1986, the following number of tornadoes were observed to have touched down in nearby counties: St. Louis City and County, 38; Jefferson, 20; Franklin, 16; Warren, 5; Montgomery, 9; and Lincoln, 10. From 1918 to 1989, 20 tornadoes were observed in St. Charles County. Only a limited number of tornadoes observed in these counties were associated with extensive damage and/or loss of life (Tucker 1989).

\subsubsection{Soils and Geology}

Three distinct types of unconsolidated surficial material are present in the area of the Weldon Spring quarry: loess deposits and residual soils that cover the upland regions, river alluvium that is found along the Misso sri River, and tributary alluvium in the stream valleys. The principal surficial deposit on this top of the bluffs and upland surfaces in the vicinity of the quarry is a silty clay loam developed from loess and deposited during and 
following the Wisconsinan glaciation. A residual soil derived from weathering of the surficial bedrock formations is present in some areas between the silty loam and bedrock.

Along the Missouri River floodplain to the south and east of the quarry, the principal surficial deposit is river alluvium. This deposit includes clay, silt, sand, and gravel intermixed and interbedded (Whitfield et al. 1989). Tributary alluvium is present in the stream valley of Little Femme Osage Creek, which dissects the upland area to the north of the quarry. This deposit is gravelly in places, but where the tributary adjoins the floodplains of the Missouri River, gravel deposits are covered by fine-textured silts and clays (Whitfield et al. 1989).

The surface of the Weldon Spring region is almost entirely covered by unconsolidated materials consisting of weathered rock (residuum), glacial drift, loess, and alluvium. In the rugged hilly areas of the region that are located marginal to the Missouri River Valley, bedrock is overlain by variable thicknesses of weathered rock and loess. Numerous bedrock outcrops occur along natural drainage channels that transect the region, including steep and massive exposures along the flanks of the Missouri and Mississippi rivers. Bedrock is exposed on the quarry walls and on the precipitous bluffs along the Missouri River. The bedrock is overlain in upland areas by 3 to $12 \mathrm{~m}$ (10 to $40 \mathrm{ft})$ of silty clay, derived from winddeposited glacial debris and glacial till (Berkeley Geosciences Associates 1984). In the area of the Missouri River floodplain, the bedrock is overlain by as much as $30 \mathrm{~m} \mathrm{(100} \mathrm{ft)} \mathrm{of}$ alluvium (Layne Western Company 1986). The bedrock underlying the soil cover consists of limestone, shale, dolomite, and sandstone (DOE 1989). The generalized stratigraphy and hydrostratigraphy of the Weldon Spring area is shown in Table 1.

The bedrock in the Weldon Spring area has a regional strike of $\mathrm{N} 60^{\circ} \mathrm{W}$, with a regional dip of approximately $0.5^{\circ}$ to the northeast. The strata of the region have been broadly uplifted by the Ozark doming that resulted in a northeast-sloping monoclinal structure (Bechtel National 1987). Roberts and Theis (1951) identified two major joint sets in the Weldon Spring area, one set trending between $\mathrm{N} 30^{\circ} \mathrm{E}$ and $\mathrm{N} 72^{\circ} \mathrm{E}$ and a second set trending between $\mathrm{N} 30^{\circ} \mathrm{W}$ and $\mathrm{N} 65^{\circ} \mathrm{W}$. The joint planes are nearly vertical.

The uppermost bedrock unit in the vicinity of the quarry is Kimmswick Limestone of Ordovician age. The Kimmswick Limestone is underlain by other Ordovician strata that include, in descending order, the Decorah Group (shale and limestone), the Plattin Limestone, the Joachim Dolomite, and the St. Peter Sandstone. The sides of the quarry expose the Kimmswick Limestone, whereas the bedrock floor of the quarry lies in the upper portion of

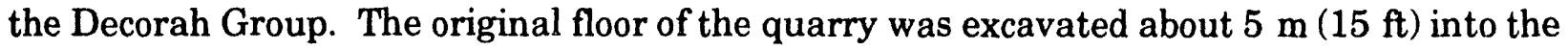
Decorah Group (DOE 1989).

The Kimmswick Limestone, mined during quarry operations, is predominantly a crystalline limestone and is approximately 15 to $24 \mathrm{~m} \mathrm{(50} \mathrm{to} 80 \mathrm{ft}$ ) thick. It is highly fossiliferous, medium to coarsely crystalline, medium to thick bedded, and cherty near the base (Whitfield et al. 1989). The Kimmswick Limestone is characterized by solution-enlarged features associated with the intersection of vertical joints, bedding planes, and fractures. The 
TABLE 1 Stratigraphy and Hydrostratigraphy of the Weldon Spring Area

\begin{tabular}{|c|c|c|c|c|c|}
\hline System & Series & Stratigraphic Unit & $\begin{array}{l}\text { Typical } \\
\text { Thickness } \\
\text { (ft) }\end{array}$ & Physical Characteristics & $\begin{array}{l}\text { Hydrostratigraphic } \\
\text { Unit }^{\mathrm{a}}\end{array}$ \\
\hline \multirow[t]{2}{*}{ Quaternary } & Holocene & Alluvium & $10-110$ & Gravelly, silty loam & Alluvial Aquifer \\
\hline & Pleistocene & Loess and Glacial Drift & $15-55$ & $\begin{array}{l}\text { Silty clay, gravelly clay. silty loam, clay, or } \\
\text { loam over residuum orom weathered bedrock }\end{array}$ & (Unsaturated) $^{\mathbf{b}}$ \\
\hline \multirow[t]{5}{*}{ Mississippian } & Meramecian & Salem Formation & $0-15$ & $\begin{array}{l}\text { Limestone, limy dolowite, finely to coarsely } \\
\text { crystalline, massively bedded, and thin- } \\
\text { bedded shale }\end{array}$ & (Unsaturated $^{\mathbf{b}}$ \\
\hline & & Warsaw Formation & $60-80$ & $\begin{array}{l}\text { Shale and thin- to medium-bedded finely } \\
\text { crystalline limestone with interbedded chert }\end{array}$ & (Unsaturated) $^{\mathbf{b}}$ \\
\hline & Osagean & $\begin{array}{l}\text { Burlington-Keokuk } \\
\text { Limestone }\end{array}$ & $100-200$ & $\begin{array}{l}\text { Cherty limestone, very fine to very coarsely } \\
\text { crystalline, fossiliferous, thick bedded to } \\
\text { massive }\end{array}$ & $\begin{array}{l}\text { Mississippian-Devonian } \\
\text { Aquifer Syster. }\end{array}$ \\
\hline & & Fern Glen Formation & $45-70$ & $\begin{array}{l}\text { Cherty limestone, dolomitic in part, very fine } \\
\text { to very coarsely crystalline, medium to thick } \\
\text { bedded }\end{array}$ & \\
\hline & Kinderhookian & Chouteau Group & $20-50$ & $\begin{array}{l}\text { Dolomitic, argillaceous limestone; finely } \\
\text { crystalline, thin to medium bedded }\end{array}$ & \\
\hline \multirow[t]{5}{*}{ Devonian } & Upper & Bushberg Sandstone & $5-20$ & $\begin{array}{l}\text { Quartz arenite, fine to medium grained, } \\
\text { friable }\end{array}$ & \\
\hline & & $\begin{array}{l}\text { Lower Sulfur Springs } \\
\text { Group (Undifferentiated) }\end{array}$ & $0-2$ & $\begin{array}{l}\text { Calcareous siltstone, sandstone, oolitic } \\
\text { limestone, and hard carbonaceous shale }\end{array}$ & $\begin{array}{l}\text { Ordovician Leaky } \\
\text { Confining Unit }\end{array}$ \\
\hline & Cincinnatian & Maquoketa Shale & $10-30$ & $\begin{array}{l}\text { Calcareous to dolomitic silty shale and } \\
\text { mudstone, thinly laminated to massive }\end{array}$ & \\
\hline & Champlainian & Kimmswick Limestone & $70-100$ & $\begin{array}{l}\text { Limestone, coarsely crystalline, medium to } \\
\text { thick bedded, fossiliferous and cherty near } \\
\text { base }\end{array}$ & \\
\hline & & Decorah Group & $30-60$ & $\begin{array}{l}\text { Shale with thin interbeds of very finely } \\
\text { crystalline limestone }\end{array}$ & \\
\hline
\end{tabular}


TABLE 1 (Cont.)

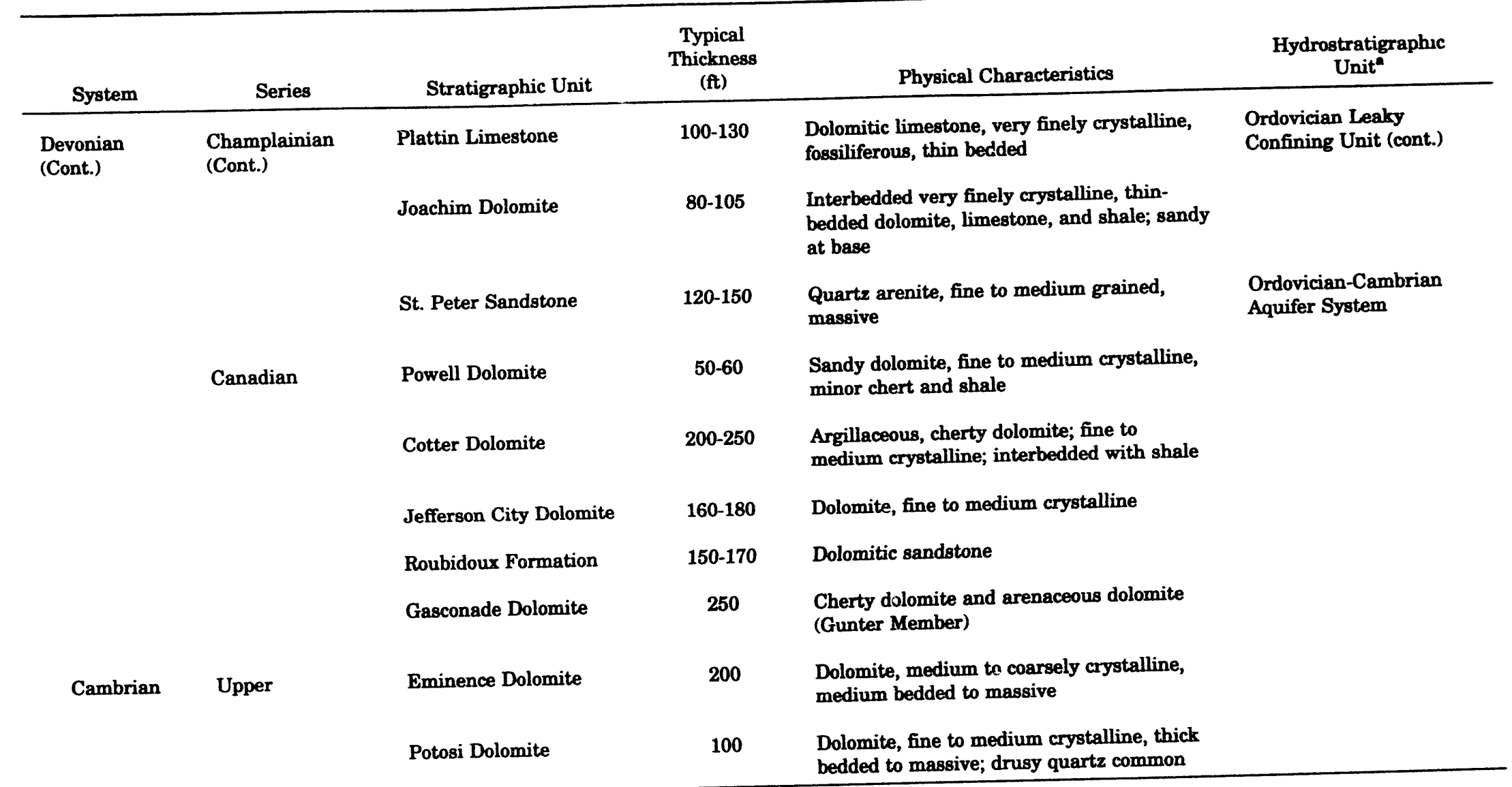

a When no hydrostratigraphic unit is listed, the unit is the same as for the preceding entry.

b These units are believed to be unsaturated in the vicinity of the Weldon Spring site.

Sources: Data from Kleeschulte and Emmett (1987); Whitfield et al. (1989); DOE (1992d). 
Decorah Group lies below the Kimmswick Limestone and is composed of finely crystalline to

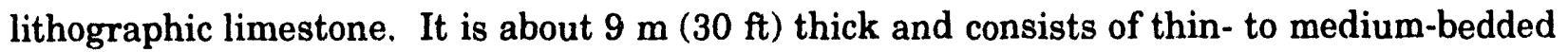
limestones with interbedded gray, clayey, fossiliferous shales (Whitfield et al. 1989).

Underlying the Kimmswick Limestone and the Decorah Group is the Plattin Limestone, a slightly cherty limestone that is finely crystalline to lithographic and thin to medium bedded. The lower 1.5 to $3 \mathrm{~m} \mathrm{(5} \mathrm{to} 10 \mathrm{ft}$ ) is sometimes a dolomitic limestone that is argillaceous and fine to medium crystalline. It ranges in thickness from about 24 to $41 \mathrm{~m}$ ( 80 to $135 \mathrm{ft}$ ) and contains enlarged solution joints in many places (Whitfield et al. 1989).

The Joachim Dolomite, which ranges from 18 to $24 \mathrm{~m}$ (60 to $80 \mathrm{ft}$ ) in thickness, underlies the Plattin Limestone. The unit varies from dolomite to calcareous dolomite and is described as finely crystalline, argillaceous, silty, and thin to massively bedded. The upper portion varies from vuggy, with irregular bedding, to shaly (Whitfield et al. 1989). The

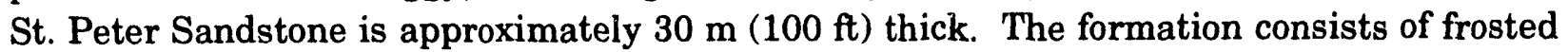
quartz sandstone of exceptional purity that is weakly cemented, well sorted, and medium to fine grained (Whitfield et al. 1989).

East and south of the quarry, the Kimmswick Limestone and Decorah Group were truncated by erosion followed by alluvial deposition. The alluvium extends from the base of the bedrock bluffs along Katy Trail to the Missouri River. Along the first $305 \mathrm{~m}(1,000 \mathrm{ft})$ south of the cliffs, the alluvium thickens until it levels off at a maximum thickness of about $30 \mathrm{~m}$ (100 ft) in the area of the St. Charles County well field (DOE 1989). The primary sediments between the bedrock bluffs and Femme Osage Slough are silts and clays, with one or two sand lenses that range in thickness from 3 to $5 \mathrm{~cm}$ (1 to $2 \mathrm{in}$.). Between the quarry and Little Femme Osage Creek are silts and clays, with several layers of sand down to

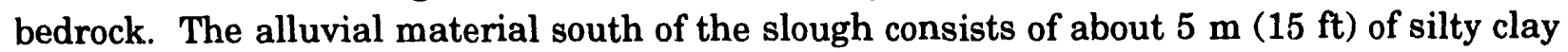
material underlain by well-graded sands and gravels to bedrock.

As part of a previous investigation, geologic cross sections and bedrock elevation maps were constructed from drill logs of boreholes. The locations of the cross sections are shown in Figure 4. The cross sections were drawn through the quarry or parallel to Femme Osage Slough (Figures 5 through 8). Of interest is the sloping bedrock surface at the alluvium-bedrock contact and the nature of the alluvial sediments adjacent to Femme Osage Slough. The base of the Kimmswick Limestone and Decorah Group, which may provide the primary pathways for migration of contaminants from the quarry area, is in contact with fine-grained soils, silty clay, and organic silt and clay in the area of the slough (DOE 1989).

Berkeley Geosciences Associates (1984) conducted a fracture mapping program to identify potential conduits for fluid flow in the quarry limestone. The location of each fracture with a trace length greater than $3 \mathrm{~m} \mathrm{(10} \mathrm{ft)} \mathrm{was} \mathrm{recorded,} \mathrm{along} \mathrm{with} \mathrm{the} \mathrm{orientation}$ and characteristics of the fracture openings. The joints are open, with apertures ranging from $2.5 \mathrm{~cm}$ ( $1 \mathrm{in}$.) to nearly $1 \mathrm{~m}(3 \mathrm{ft})$, and are generally vertical. The dominant fracture set is oriented $\mathrm{N} 70^{\circ} \mathrm{W}$; two additional minor sets are oriented $\mathrm{N} 60^{\circ} \mathrm{E}$ and north-south. Clay 


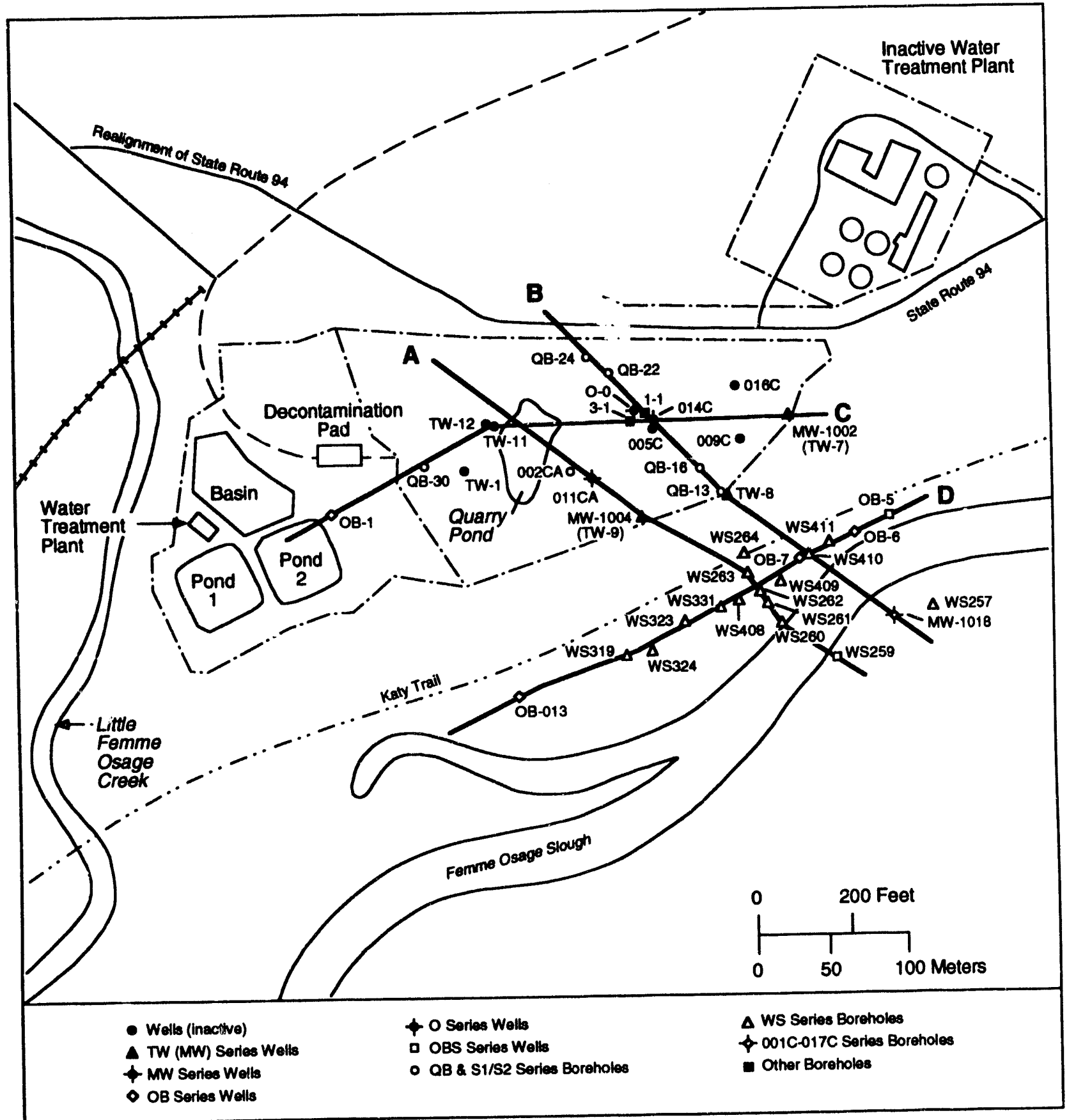

FGURE 4 Geologic Cross Section Locations for the Weldon Spring Quarry (Source: Modified from DOE 1989) 

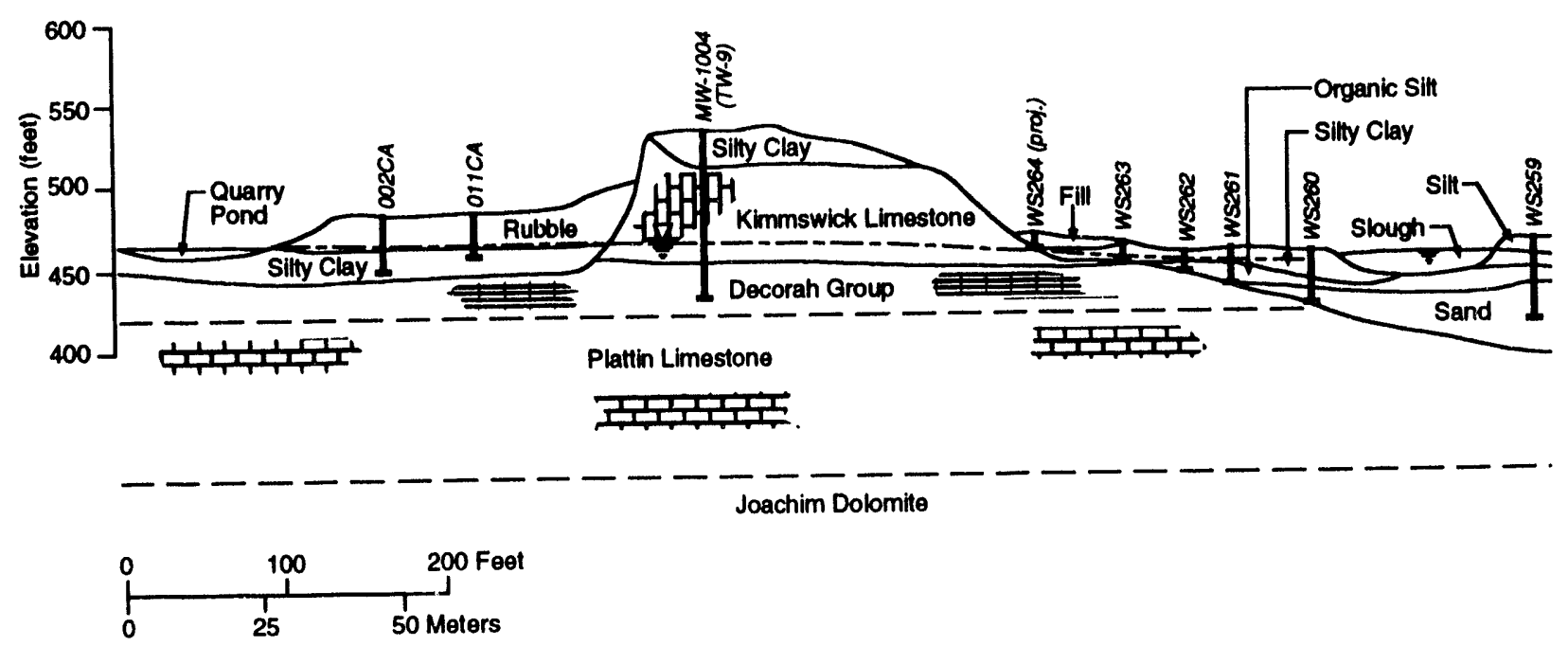

FIGURE 5 Geologic Cross Section A across the Quarry (Source: Modified from DOE 1989)

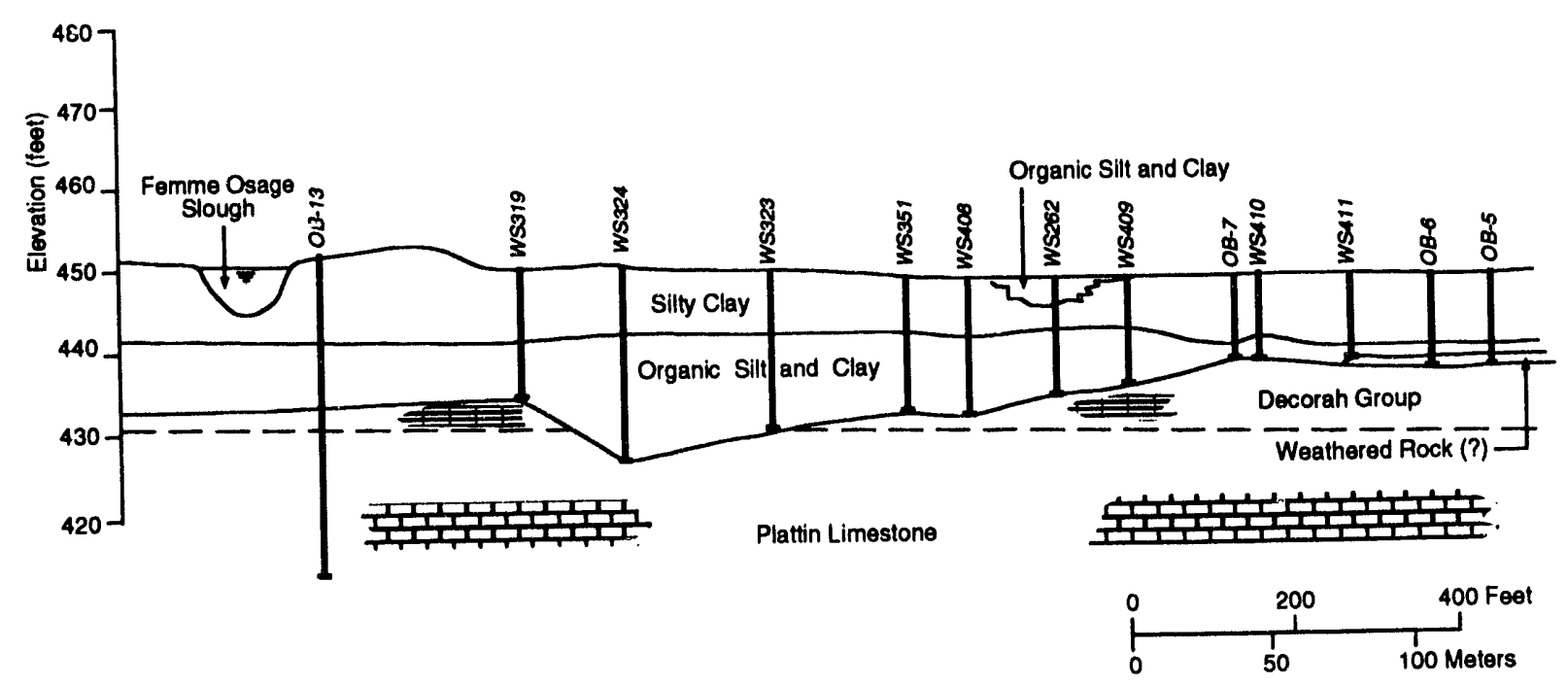

FIGURE 6 Geologic Cross Section D Parallel to the Slough (Source: Modified from DOE 1989) 


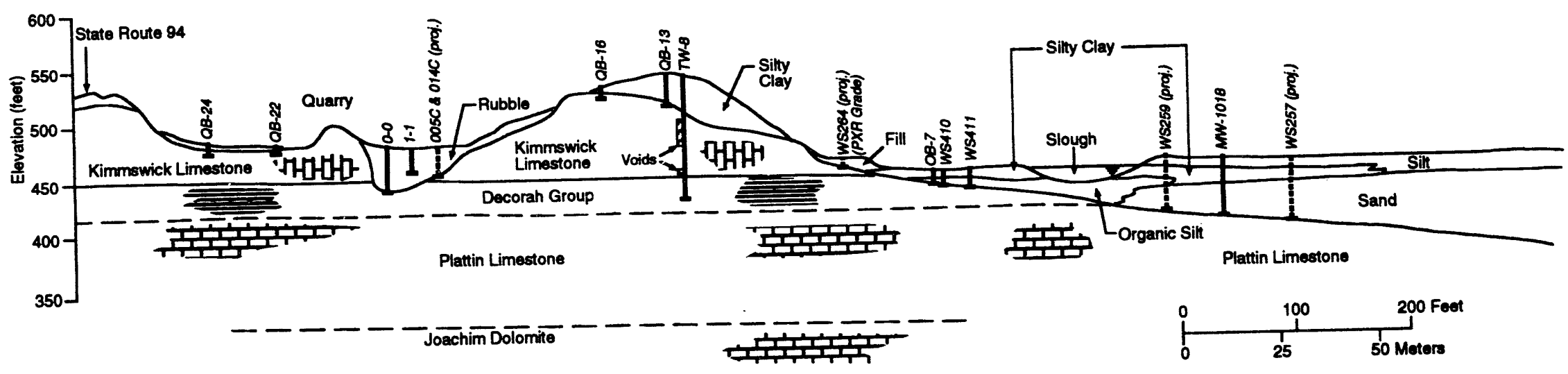

FIGURE 7 Geologic Cross Section B across the Quarry (Source: Modified from DOE 1989)

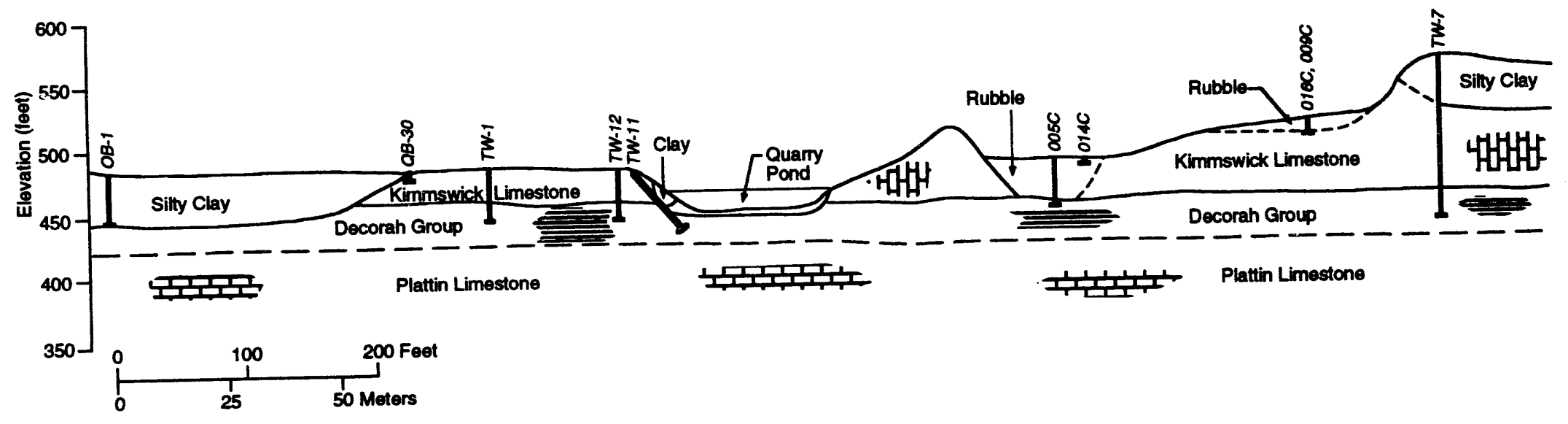

FIGURE 8 Geologic Cross Section C across the Quarry (Source: Modified from DOE 1989) 
fillings are present in many of the joints. The fracture surfaces along the bluff and on the quarry walls are typically etched with patterns, indicating that most of the fractures have been in contact with groundwater. Field observations and borehole infiltration tests suggest that the joints become increasingly tight with depth (Berkeley Geosciences Associates 1984).

\subsubsection{Water Resources}

\subsubsection{Surface Water Hydrology}

The Weldon Spring quarry is about $1.6 \mathrm{~km}(1 \mathrm{mi})$ northwest of the Missouri River and about $29 \mathrm{~km}(18 \mathrm{mi})$ southwest of the Mississippi River. The drainage divide between the two rivers transects the east-southeast portion of the Weldon Spring chemical plant area to the north of the quarry. Streams in the vicinity of the quarry include Femme Osage Creek, Little Femme Osage Creek, and an unnamed tributary to Little Femme Osage Creek - which ultimately flow into the Missouri River (DOE 1989) (Figure 3).

Drainage at the quarry occurs primarily through the subsurface, with limited surface drainage on the western and southern rims. Outside of the quarry rim, runoff flows to the Missouri River through the drainages of Little Femme Osage Creek and Femme Osage Creek (DOE 1990a). Because the high quarry rim prevents any entry of surface flow from the surrounding area, water influent to the quarry is limited to precipitation or subsurface flow.

About $150 \mathrm{~m}(500 \mathrm{ft})$ south of the quarry is a $2.4-\mathrm{km}(1.5-\mathrm{mi})$ section of the original Femme Osage Creek and a smaller section of the original Little Femme Osage Creek; these sections were cut off from their natural channels by a levee constructed by the University of Missouri during 1959 and 1961. Flows in both Femme Osage Creek and Little Femme Osage Creek were diverted outside the levee system to prevent flooding of the farmland and the well field located inside the earthenwork levee. The downstream reaches of these creeks now form an isolated body of water known as Femme Osage Slough (Kleeschulte and Emmett 1986).

Water levels (stage) in the slough are influenced by stage in the Missouri River and are managed by the Missouri Department of Conservation. Water is allowed to fill the slough during periods of high stage in the Missouri River, and the control valve is closed at high stage in the slough to retain the water there (MK-Ferguson Company and Jacobs Engineering Group 1992c). During low river stage, this valve is normally left open. The average water elevation in the slough is about $140 \mathrm{~m} \mathrm{(450} \mathrm{ft)} \mathrm{MSL} \mathrm{(DOE} \mathrm{1987).}$

The bottom of the Missouri River near the quarry at river mile (RM) 49 from the confluence with the Mississippi River is at an elevation of about $129 \mathrm{~m}$ (422 $\mathrm{ft}$ ) MSL (DOE 1990b). The elevations for 100-year and 500-year floods on the Missouri River at RM 49 are 144.1 and $144.7 \mathrm{~m}$ (472.8 and 474.6 ft) MSL, respectively (U.S. Army Corps of Engineers 1988). The elevation of the 100-year flood on Femme Osage Creek is $144.5 \mathrm{~m}$ (474 $\mathrm{ft}$ ) MSL from its mouth to the confluence with Little Femme Osage Creek (Federal Insurance Administration, undated). Although the floodplain area below the south rim of the quarry 
is partially behind a levee system, the area floods every 3 to 5 years and requires 1 to 2 months to dry (DOE 1987).

\subsubsection{Hydrogeology}

Groundwater in the vicinity of the quarry occurs in alluvium, fractured limestone, and sandstone (Berkeley Geosciences Associates 1984). The shallow groundwater system is composed of carbonate rocks near the quarry, tributary alluvium near the Little Femme Osage Creek, and Missouri River alluvium between the quarry bluff and the Missouri River. Water-table (unconfined) conditions typically occur in the alluvium where significant deposits exist; confined to semiconfined conditions occur in the bedrock and alluvium where layers of

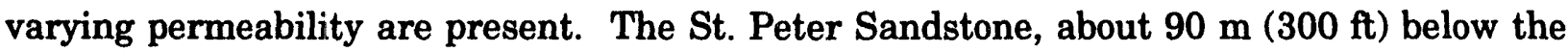
floor of the quarry, composes the deeper aquifer.

The saturated carbonate rocks of the shallow groundwater system include three Ordovician formations: Kimmswick Limestone, Decorah Group, and Plattin Limestone. Previous characterization studies of the upper bedrock at the quarry indicate that porosity is primarily a function of fractures, joints, bedding planes, and solution-enhanced cavities. These studies confirm that groundwater flow is governed by secondary porosity as a result of the joints and fractures in the upper Ordovician units near the quarry (Richardson 1960; Huey 1978; Berkeley Geosciences Associates 1984). Solution-enlarged cavities occur in the near-surface weathered portions of the Kimmswick Limestone in the immediate vicinity of the quarry, but these are generally above the current ground-water table (Berkeley Geosciences Associates 1984). South of the quarry, groundwater flow is likely a combination of flow through porous media composed of alluvium and flow through fractures in the underlying limestone.

Regionally, the Decorah Group is considered to be a leaky confining layer due to shale beds (Kleeschulte and Emmett 1986). As described in Section 2.3.2, a fracture mapping program, geophysica! borehole logging, and core logging of fractures and joints have been conducted in the immediate vicinity of the quarry (Berkeley Geosciences Associates 1984). The fracture patterns observed on the surface were found to extend in depth at least through the Decorah Limestone. The results of this investigation suggest that, locally, the Kimmswick Limestone and Decorah Group may be considered to be one continuous hydrostratigraphic unit in the quarry area.

The results of vertical core logging performed in the vicinity of the quarry indicate that the Plattin Limestone is massive with very little fracturing. Currently, water levels within the Plattin Limestone do not appear to correlate with water levels measured in the Kimmswick Limestone/Decorah Group. On the basis of this information, the Plattin Limestone is considered to be a separate hydrostratigraphic unit. Regionally, the Plattin Limestone and the Joachim Dolomite constitute the lower portions of the leaky confining layer of the deeper Ordovician-Cambrian groundwater system. 
The St. Peter Sandstone is the uppermost bedrock aquifer of regional significance in the quarry area. A map of the potentiometric surface of the deep bedrock aquifer indicates

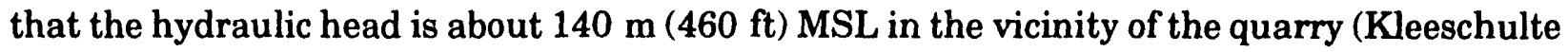
and Emmett 1986, 1987). This elevation is just below the water level in the quarry pond,

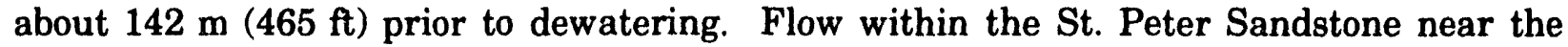
quarry is generally south toward the Missouri River; however, southwest of the quarry, the Femme Osage Creek is a local discharge point for deep groundwater where the St. Peter Sandstone is exposed at the land surface. The possibility of contamination migrating to the deep bedrock aquifer from the current sources in the QROU is considered extremely remote because of the thick sequence of intervening confining layers and the strong upward hydraulic gradient present within this aquifer.

In the vicinity of the quarry area, groundwater in the shallow aquifer flows primarily from north to south, although an average of water-level measurements taken from 1987 through 1992 indicates a mounding of groundwater in the immediate vicinity of the quarry (Figure 9). About $215 \mathrm{~m}$ (700 ft) west of the quarry, the bottom of Little Femme Osage Creek

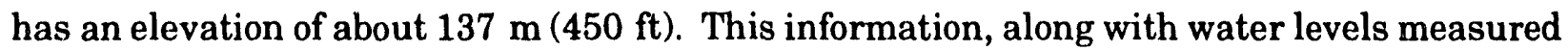
in monitoring wells located west of the quarry, indicates that a westward gradient runs from the quarry to Little Femme Osage Creek (DOE 1989).

South of the quarry rim, the direction of groundwater flow is generally south toward Femme Osage Slough. Groundwater levels measured in the bedrock along the southern rim of the quarry are consistently about 3 to $6 \mathrm{~m}$ (10 to $20 \mathrm{ft}$ ) higher in elevation compared with the levels measured in the alluvium south of the slough. This abrupt change in groundwater elevation near the interface creates a fairly steep hydraulic gradient of about 0.05 toward the south (DOE 1989). In the alluvium south of the slough, groundwater is within $3 \mathrm{~m} \mathrm{(10 \textrm {ft } )}$ of the ground surface, although the depth to water varies with season and $\mathrm{fumping}$ demands in the nearby St. Charles County well field (DOE 1990b).

Between Katy Trail and the slough, the gradient is generally southward toward the slough (Figure 9); south of the slough, the direction of groundwater flow may vary. In general, the groundwater elevation data indicate a southeast gradient across the slough. The groundwater flow direction at the western end of the slough seems to vary, depending on the stage of the Missouri River. At low river stages, the slough may act as a recharge feature for the shallow groundwater; however, at other times, groundwater may flow southeast across the slough. A previous study performed in this area indicated that, during drought conditions, Femme Osage Slough was isolated from the alluvial aquifer. Groundwater levels measured immediately south of the slough were about 2 to $3 \mathrm{~m} \mathrm{(5} \mathrm{to} 8 \mathrm{ft}$ ) lower than the water elevation within the slough, indicating a poor hydraulic connection between the slough and the alluvium (MK-Ferguson Company and Jacobs Engineering Group 1988).

Recharge to the bedrock in the vicinity of the quarry is limited to infiltration from precipitation or storm runoff. Discharge from the bedrock to the alluvium of the Missouri River floodplain may occur as springs, seeps, underflow, flow to pumping wells, and flow to 


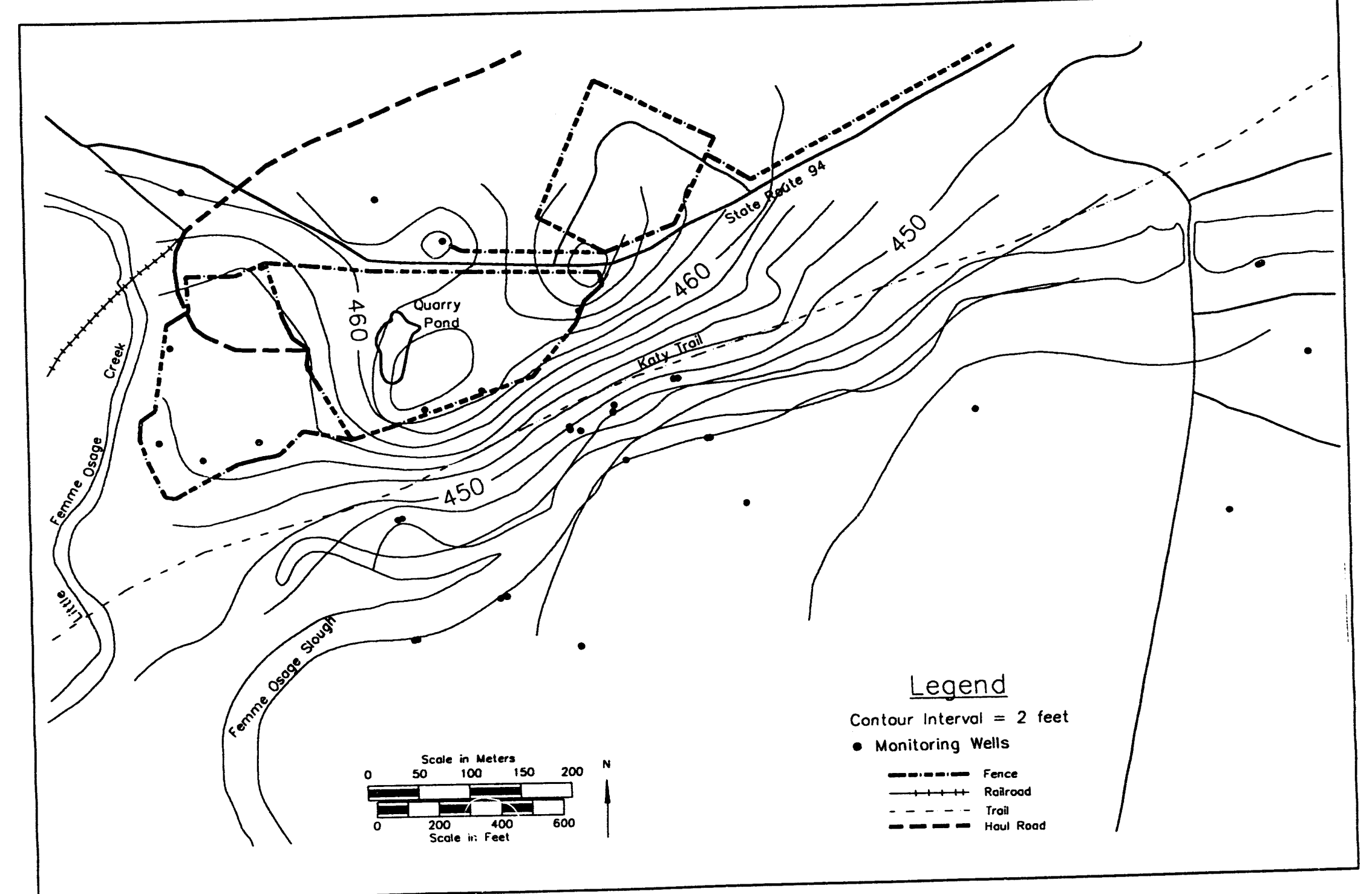

FIGURE 9 Map of the Shallow Water Table Surface Contoured from Average Water Level Measurements for 1986 through 1992 
gaining streams (DOE 1989). Recharge to the alluvium south of the slough occurs primarily from the Missouri River and intermittent surface flooding, with minor amounts derivec from infiltration and the underlying and adjacent bedrock.

Several studies have been performed to determine the hydrogenlogic properties of the bedrock near the quarry and the alluvium north and south of Femme Osage Slough. Pumping tests and pressure tests were performed at the quarry by the U.S. Geological Survey (USGS) (Richardson 1960). These tests indicated that the pond within the quarry is hydraulically connected to the carbonate aquifer and that the natural groundwater gradient at the quarry slopes toward the alluvium of the Missouri River floodplain, resulting in the potential for migration of contaminants from the quarry to the alluvium. According to

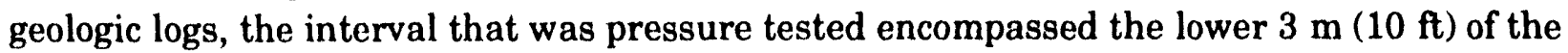

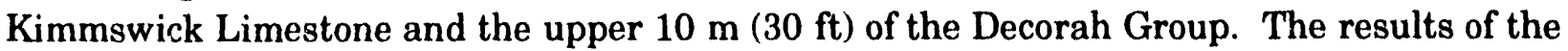
pressure tests indicated that the permeability within the upper bedrock decreases with increasing depth (Richardson 1960).

Berkeley Geosciences Associates (1984) conducted pumping tests and a tracer test to determine the hydraulic properties of the carbonate aquifer between the quarry and the slough. The formations in which the tests were performed were not identified; however, on the basis of current knowledge regarding the local lithology and considering the depth at which the tests were performed, it was concluded that the tests were conducted in the upper portion of the Plattin Limestone and possibly a few meters of the lower Decorah Group. The results of these tests are presented in Table 2.

For the purpose of the preliminary study, Berkeley Geosciences Associates (1984) discounted the anomalously high and low values and calculated an average transmissivity of $2 \times 10^{-5} \mathrm{~m}^{2} / \mathrm{s}\left(2.2 \times 10^{-4} \mathrm{ft}^{2} / \mathrm{s}\right)$ and an average storativity of $1 \times 10^{-4}$ to be representative of the lower Decorah Group/upper Plattin Limestone in the area of the quarry. These values are slightly lower than the average values presented in Table 2, which were calculated from all the data. Effective porosity values of 0.1 and $0.2 \%$ were calculated from the tracer test, probably indicating the presence of two major fracture flow paths of differing apertures and effective permeabilities within the limestone. Berkeley Geosciences Associates (1984) concluded from these tests that virtually all of the flow occurs in the fractures of the limestone.

Hydrogeologic testing was also conducted in the alluvium between the quarry and Femme Osage Slough and south of the slough (Berkeley Geosciences Associates 1984). The hydraulic properties of the alluvium are highly variable, depending on the thickness and dominant grain size of the material at a given location. The results of the tests indicated that the material north of the slough has substantially different hydraulic properties than the material to the south. Development of observation wells installed between the quarry and the slough involved extended recovery periods following pumping. Because of the apparent tightness of the alluvium in this area and its relatively limited extent, detailed hydraulic testing was not performed. 
TABLE 2 Hydraulic Properties Estimated from Aquifer Tests Performed in the Fractured Limestone and in the Alluvium South of Femme Osage Slough

\begin{tabular}{|c|c|c|c|}
\hline Stratum & $\begin{array}{l}\text { Transmissivity } \\
\left(\mathrm{m}^{2} / \mathrm{s}\right)\end{array}$ & Storativity & $\begin{array}{l}\text { Effective } \\
\text { Porosity } \\
(\%)\end{array}$ \\
\hline $\begin{array}{l}\text { Fractured limestone } \\
\text { Minimum } \\
\text { Maximum } \\
\text { Average } \\
\text { Standard deviation }\end{array}$ & $\begin{array}{l}3.7 \times 10^{-6} \\
2.0 \times 10^{-4} \\
4.9 \times 10^{-5} \\
5.5 \times 10^{-5}\end{array}$ & $\begin{array}{l}6.7 \times 10^{-5} \\
3.8 \times 10^{-3} \\
6.4 \times 10^{-4} \\
1.3 \times 10^{-3}\end{array}$ & $\begin{array}{c}0.1 \\
0.2 \\
- \\
-\end{array}$ \\
\hline $\begin{array}{l}\text { Alluvium south of } \\
\text { Femme Osage Slough } \\
\text { Minimum } \\
\text { Maximum } \\
\text { Average } \\
\text { Standard deviation }\end{array}$ & $\begin{array}{l}1.2 \times 10^{-6} \\
1.0 \times 10^{-3} \\
1.3 \times 10^{-3} \\
1.4 \times 10^{-3}\end{array}$ & $\begin{array}{l}1.5 \times 10^{-4} \\
1.9 \times 10^{-2} \\
7.9 \times 10^{-3} \\
1.0 \times 10^{-2}\end{array}$ & $\begin{array}{c}21 \\
32 \\
- \\
-\end{array}$ \\
\hline $\begin{array}{l}\text { a Values calculated or } \\
\text { Association (1984). }\end{array}$ & oasis of data & erkeley & nces \\
\hline
\end{tabular}

The results of pumping tests and tracer tests conducted in the alluvium south of the slough are presented in Table 2 . The average transmissivity and storativity values calculated for the alluvium south of the slough are $1.3 \times 10^{-3} \mathrm{~m}^{2} / \mathrm{s}\left(1.4 \times 10^{-2} \mathrm{ft}^{2} / \mathrm{s}\right)$ and $7.9 \times 10^{-3}$, respectively. The effective porosity values were calculated from the tracer tests, with the minimum and maximum values reflecting the uncertainty in the thickness of the flow domain of the test (Berkeley Geosciences Associates 1984).

The storage term for unconfined aquifers is generally referred to as specific yield or unconfined storativity. The specific yields of unconfined aquifers typically range from 0.01 to 0.30 and are much higher than storativities of confined aquifers (Freeze and Cherry 1979). However, in this discussion, the storage term is referred to as storativity because that is the word originally used by Berkeley Geosciences Associates and because the reported values appear to be more representative of confined-to-semiconfined groundwater systems.

Point dilution tests were conducted to estimate the magnitude of natural groundwater velocities in the alluvium and upper bedrock near the south side of the slough and within the alluvium away from the slough (Berkeley Geosciences Associates 1984). The unidentified bedrock formation in which the point dilution test was performed was probably the Plattin Limestone. The results of the tests conducted in the alluvium adjacent to the slough indicate negligible groundwater velocity (i.e., the calculated velocities were below the resolution of the test). In contrast, the test performed in the alluvium at a greater distance from the slough indicated a velocity of $2.9 \times 10^{-6} \mathrm{~m} / \mathrm{s}\left(9.5 \times 10^{-6} \mathrm{ft} / \mathrm{s}\right)$. Finally, the test in the 
upper Plattin Limestone adjacent to the slough suggests a velocity of $6.9 \times 10^{-7} \mathrm{~m} / \mathrm{s}$ $\left(2.3 \times 10^{-6} \mathrm{ft} / \mathrm{s}\right)$. Berkeley Geosciences Associates (1984) concluded from these results that groundwater may be flowing through the fractured limestone under the slough, but additional tests should be performed for verification.

Layne Western Company (1986) conducted a pump test in the lower and productive portion of the St. Charles County well field to determine hydraulic properties of the Missouri River alluvium. One of the existing pumping wells, PW-8, was used for the test. Monitoring and observation wells were installed in the vicinity of the test well and throughout the well field to determine the response of the aquifer to large-scale test pumping. The transmissivity values determined from the pump test ranged from $5.8 \times 10^{-4}$ to $6.5 \times 10^{-4} \mathrm{~m}^{2} / \mathrm{s}$, and the specific yield of the aquifer was estimated to be above 0.01 . The results of the aquifer tests - combined with formation logs, sand gradation tests, and laboratory permeability values - were used to estimate transmissivity values near Femme Osage Slough and throughout the well field area. It was concluded that aquifer transmissivity decreases to the north toward Femme Osage Slough (Layne Western Company 1986).

\subsubsection{Ecological Resources}

The Weldon Spring quarry is located within the Bluestem Prairie, Oak-Hickory Forest Mosaic (northern) subsection of the Prairie Parkland Province (Bailey 1978). The OakHickory Forest (northern) subsection also occurs within the Weldon Spring area. Much of the land surrounding the quarry is state-owned conservation areas containing second-growth forest (August A. Busch Memorial Conservation Area, Weldon Spring Conservation Area, and Howell Island Conservation Area). Nonforested areas, which comprise much of St. Charles County, are largely used for crop production and pasture or are old-field habitat.

Habitat types in the vicinity of the quarry include crop fields, old fields, forests (upland, slope, and bottomland), and cultivated fields. Old-field habitats support species such as Indian mallow, crabgrass, ragweed, aster, Canada thistle, mustard, fleabane, and goldenrod. Cultivated fields contain harvestable crops, whereas pastures contain herbaceous plants for livestock grazing. The tree layer of upland forests in the area is dominated by oak and hickory species. The quarry area consists of slope and bottomland forests dominated by eastern cottonwood. Other overstory tree species within the slope forests include oak, hickory, sugar maple, American elm, and black walnut. In addition to the eastern cottonwood, bottomland forests include willow, silver maple, American elm, boxelder, red mulberry, pecan, pin and bur oaks, hackberry, and persimmon. Much of the quarry floor is old-field habitat characterized by a variety of grasses, herbs, and shrubs.

Common mammal species expected to occur in the quarry area include the eastern cottontail rabbit, opossum, raccoon, white-tailed deer, and several species of mice, voles, shrews, squirrels, bats, and foxes. Common reptile and amphibian species include bullfrog, spring peeper, and a variety of salamanders, turtles, and snakes. Common birds in the area include a variety of warblers, sparrows, and other songbirds; red-tailed hawk; American kestrel; barred owl; and downy, pileated, and red-bellied woodpeckers. About 10 waterfowl 
species are common to abundant during the spring and fall migration, and a few species such as the Canada goose, mallard, and wood duck nest or overwinter in the area.

Aquatic habitats in the vicinity of the quarry include the Missouri River, Little Femme Osage Creek, Femme Osage Creek, Femme Osage Slough, and numerous small, unnamed creeks, drainages, and ponds throughout the Weldon Spring Conservation Area. In addition, the nearby August A. Busch Memorial Conservation Area contains more than 35 ponds and lakes ranging in size from 0.4 to 74 ha (1 to 180 acres); however, these ponds and lakes are in the Mississippi drainage and are not influenced by the quarry area. The Missouri Department of Conservation lists over 105 species of fish for St. Charles County (Dickneite 1988). On the basis of habitats and distributions of Missouri fish, the species most likely to be abundant in the quarry vicinity include gar, gizzard shad, carp, river carpsucker, buffalo, channel catfish, freshwater drum, white bass, sturgeon, paddlefish, blue catfish, and blue sucker. Largemouth bass, bluegill, and crappie are also abundant in backwaters and oxbows.

The Missouri Department of Conservation Natural Heritage Database (Gaines 1988; Dickneite 1988; Figg 1991) has identified 13 state endangered and 19 state rare species for St. Charles County (Table 3). Five of the state-listed species are also federal-listed as threatened or endangered, and another five are federal candidate (C2) species. However, no federal-listed threatened or endangered species, candidate species, or critical habitats have been identified by the U.S. Fish and Wildlife Service as occurring at the Weldon Spring site (Tieger 1988; Nash 1990). The Natural Heritage Database includes 11 additional species from St. Charles County as state watch list species or of undetermined status (Table 3).

The Natural Heritage Database lists six federal- and/or state-listed species as occurring in or near the Busch Conservation Complex: bald eagle, sicklefin chub, sturgeon chub, Cooper's hawk, wood frog, and arrow arum. Also reported for the area are the pallid sturgeon, starwort, eastern massasauga, and alligator snapping turtle - as well as transient occurrences of the interior least tern and peregrine falcon (Gaines 1988). Overwintering bald eagles in the area may roost overnight at the Howell Island Conservation Area (Gaines 1988). The Blanding's turtle has recently been collected from the Busch Conservation Area (Bedan 1991), and Femme Osage Slough is potentially suitable habitat for this species (MK-Ferguson Company and Jacobs Engineering Group 1992c). Cooper's hawk and the wood frog have been observed in the Weldon Spring Conservation Area, and they could utilize the habitats at and around the quarry. Several natural habitats of high quality have also been identified in the area of the Weldon Spring site (Gaines 1988); however, none of these habitats occur at or near the quarry (DOE 1990a).

\subsubsection{Historic Resources}

The Weldon Spring quarry is located near the Missouri River in an area of limestone mantled with eolian sediment that contains a high density of archaeological remains. All major prehistoric periods spanning the last 11,000 years are represented in sites that 
TABLE 3 Threatened, Endangered, or Special Concern Species Reported from St. Charles County

\begin{tabular}{|c|c|c|c|}
\hline \multicolumn{2}{|r|}{ Species } & \multirow[b]{2}{*}{ Federal ${ }^{\mathbf{a}}$} & \multirow[b]{2}{*}{ State $^{b}$} \\
\hline Common Name & Scientific Name & & \\
\hline \multicolumn{4}{|l|}{ Plants } \\
\hline Adder's-tongue fern & Ophioglossum vulgatum var. pycnostichum & - & WL \\
\hline Arrow arum & Peltandra virginica & - & $\mathbf{R}$ \\
\hline Bugseed & Corispermum hyssopifolium & - & WL \\
\hline Forbes' saxifrage & Saxifraga pensylvanica var. forbesii & $3 \mathrm{C}$ & - \\
\hline Rose turtlehead & Chelone obliqua var. speciosa & $3 \mathrm{C}$ & $\mathbf{E}$ \\
\hline Star duckweed & Lemna trisulca & - & $\mathbf{R}$ \\
\hline Decurrent false aster & Boltonia decurrens & $\mathbf{T}$ & $\mathbf{E}$ \\
\hline \multicolumn{4}{|l|}{ Fish } \\
\hline Alabama shad & Alosa alabamae & - & $\mathbf{R}$ \\
\hline Alligator gar & Lepisosteus spatula & - & $\mathbf{R}$ \\
\hline Brown bullhead & Ameiurus nebulosus & - & $\mathbf{R}$ \\
\hline Paddlefish & Polyodon spathula & C2 & WL \\
\hline Pallid sturgeon & Scaphirhynchus albus & $\mathbf{E}$ & $\mathbf{E}$ \\
\hline Pugnose minnow & Notropis emiliae & - & WL \\
\hline Sicklefin chub & Macrhybopsis meeki & C2 & $\mathbf{R}$ \\
\hline Starhead topminnow & Fundulus dispar & - & WL \\
\hline Sturgeon chub & Macrhybopsis gelida & $\mathbf{C 2}$ & $\mathbf{R}$ \\
\hline Western sand darter & Ammocrypta clara & - & WL \\
\hline \multicolumn{4}{|l|}{ Reptiles and amphibians } \\
\hline Alligator snapping turtle & Macroclemys temminckii & C2 & $\mathbf{R}$ \\
\hline Blanding's turtle & Emydoidea blandingii & - & $\mathbf{E}$ \\
\hline Eastern massasauga & Sistrurus catenatus catenatus & $\mathrm{C2}$ & $\mathbf{E}$ \\
\hline Northern crawfish frog & Rana areolata circulosa & - & WL \\
\hline Western fox snake & Elaphe vulpina vulpina & - & $\mathbf{E}$ \\
\hline Western smooth green snake & Opheodrys vernalis blanchardi & - & $\mathbf{E}$ \\
\hline Wood frog & Rana syluatica & - & $\mathbf{R}$ \\
\hline \multicolumn{4}{|l|}{ Birds } \\
\hline American bittern & Botaurus lentiginosus & - & $\mathbf{E}$ \\
\hline Bachman's sparrow & Aimophila aestivalis & $\mathrm{C} 2$ & $\mathbf{E}$ \\
\hline Bald eagle & Haliaeetus leucocephalus & $\mathbf{E}$ & $\mathbf{E}$ \\
\hline Barn owl & Tyto alba & - & $\mathbf{R}$ \\
\hline Black-crowned night heron & Nycticorax nycticorax & - & $\mathbf{R}$ \\
\hline Cooper's hawk & Accipiter cooperii & - & $\mathbf{R}$ \\
\hline Henslow's sparrow & Ammodramus henslowii & $\mathrm{C} 2$ & $\mathbf{R}$ \\
\hline Interior least tern & Sterna antillarum & $\mathbf{E}$ & $\mathbf{E}$ \\
\hline Little blue heron & Egretta caerulea & - & $\mathbf{R}$ \\
\hline Mississippi kite & Ictinia mississippiensis & - & $\mathbf{R}$ \\
\hline Northern harrier & Circus cyaneus & - & $\mathbf{E}$ \\
\hline Osprey & Pandion haliaetus & - & EX \\
\hline Peregrine falcon & Falco peregrinus & $\mathbf{E}$ & EX \\
\hline Pied-billed grebe & Podilymbus podiceps & - & $\mathbf{R}$ \\
\hline Red-shouldered hawk & Buteo lineatus & - & WL \\
\hline
\end{tabular}


TABLE 3 (Cont.)

\begin{tabular}{|c|c|c|c|}
\hline \multicolumn{2}{|r|}{ Species } & \multirow[b]{2}{*}{ Federal $^{\mathrm{a}}$} & \multirow[b]{2}{*}{ State $^{b}$} \\
\hline Common Name & Scientific Name & & \\
\hline $\begin{array}{l}\text { Birds (Cont.) } \\
\text { Sharp-shinned hawk } \\
\text { Snowy egret } \\
\text { Upland sandpiper } \\
\text { Yellow-headed blackbird }\end{array}$ & $\begin{array}{l}\text { Accipiter striatus } \\
\text { Egretta thula } \\
\text { Bartramia longicauda } \\
\text { Xanthocephalus xanthocephalus }\end{array}$ & $\begin{array}{l}- \\
- \\
-\end{array}$ & $\begin{array}{l}\mathbf{R} \\
\mathbf{E} \\
\mathbf{W L}\end{array}$ \\
\hline \multicolumn{4}{|l|}{ Mammals } \\
\hline \multicolumn{4}{|c|}{$\begin{array}{l}\text { E, endangered; T, threatened; C2, federal candidate for listing as a threatened or endangered } \\
\text { species; 3C, former federal candidate species. A hyphen indicates that no federal status has been } \\
\text { established. }\end{array}$} \\
\hline \multicolumn{4}{|c|}{$\begin{array}{l}\text { D, endangered; EX, extirpated; R, rare; U, undetermined; WL, watch list. Special concern species } \\
\text { include those classified by the state as rare, on the watch list, or status undetermined. Watch list } \\
\text { contains species of possible concern for which the Missouri Department of Conservation is seeking } \\
\text { further information; this listing does not imply that these species are imperiled. Undetermined } \\
\text { indicates that the species is possibly rare or endangered, but insufficient information is available } \\
\text { to determine the proper status. Extirpated means formerly occurred as a regular breeding species } \\
\text { but no longer reproduces in Missouri. }\end{array}$} \\
\hline
\end{tabular}

Sources: Dickneite (1988); Gaines (1988); Bedan (1991); Figg (1991); Missouri Department of Conservation (1992).

typically occur along ridges or streams (Chapman 1975, 1980; Haas 1978). Euro-American settlers first entered the region between 1673 and 1680 and encountered Algonquin-speaking Native American groups. Although St. Louis was founded in 1764, widespread EuroAmerican settlement did not begin until after the Louisiana Purchase in 1803 (March 1967). Early Euro-American sites (e.g., farmsteads and cemeteries) are also found in the arca (Walters 1990, 1992).

Several historic site surveys have been conducted in the vicinity of the Weldon Spring quarry, quarry water treatment plant, and Femme Osage Slough. These surveys include a nonintensive reconnaissance of the Little Femme Osage/River Hills area (Haas 1978) and intensive Phase I surveys of the quarry (Walters 1988) and the haul road from the quarry to the chemical plant area (Walters 1990). The surveys documented the presence of numerous prehistoric and historic sites in the area, some of which may be considered significant (i.e., eligible for the National Register of Historic Places) (Walters 1988, 1990).

No prehistoric or historic remains occur in the quarry proper. However, two buried prehistoric sites have been recorded near the margins of the quarry (Haas 1978; Walters 1988). Site 23SC21 is located south of the quarry and comprises several graves, probably dating to the Woodland Period (1000 B.C. to 900 A.D.), and lithic debris of unknown age. Site $23 \mathrm{SC} 178$ is located east of the quarry and contains lithic debris of undetermined age. 
Although Site 23SC178 has been subject to heavy prior disturbance and is not likely to be significant, Site 23SC21 is potentially eligible for the National Register (Walters 1988). Several prehistoric sites (23SC80, 23SC90, 23SC708, and 23SC709) were originally recorded in the quarry water treatment plant area (Haas 1978; Walters 1988), but this area has been heavily disturbed and does not currently contain any significant prehistoric remains. To date, Femme Osage Slough has not been subject to intensive survey and may contain prehistoric or historic remains. Additional field studies in the vicinity of Femme Osage Slough may be undertaken if the removal of residual materials appears likely to affect previously undisturbed areas that have the potential to yield significant remains.

\subsubsection{Land Use and Population}

The Weldon Spring quarry is located within the Weldon Spring Conservation Area, which occupies a total area of 2,977 ha (7,356 acres) and is managed for recreational use by the Missouri Department of Conservation. Other conservation areas lie north (August A. Busch Memorial Conservation Area) and east (Howell Island Conservation Area) of the Weldon Spring Conservation Area. These areas are also managed for recreational use by the Missouri Department of Conservation. The Busch and Weldon Spring conservation areas collectively receive over one million visitors each year (Crigler 1992). Katy Trail traverses the Weldon Spring Conservation Area along the route of an abandoned railroad bed that runs adjacent to the south margin of the quarry. This trail, which was established by the Missouri Department of Natural Resources, was reportedly used by approximately 18,000 people during October to December 1990 (Missouri Department of Conservation 1990).

Other land uses in the quarry area include military reserve training on the U.S. Army Reserve and National Guard Training Area, which entails the use of a firing range. The Army property occupies an area of $670 \mathrm{ha}(1,655$ acres $)$ and is located about $3 \mathrm{~km}$ (2 mi) north of the quarry. About 3,300 local Army reservists and 3,400 other reserve troops may use the area each year (Daubel 1992); this property is fenced and access by the general public is restricted. A high school (Francis Howell High School) and state highway maintenance facility are located along State Route 94 east of the military training area.

Local communities include Defiance, which is situated approximately $5 \mathrm{~km}(3 \mathrm{mi})$ from the quarry and contains a population of 100 , and Weldon Spring and Weldon Spring Heights, which are located approximately $8 \mathrm{~km}(5 \mathrm{mi})$ northeast of the quarry and support a combined population of approximately 1,500 (U.S. Bureau of the Census 1991).

\subsection{NATURE AND EXTENT OF CONTAMINATION}

Although the nature and extent of contamination in the quarry will not be fully characterized until the bulk waste has been removed, projections as to the types of waste in the quarry have been postulated on the basis of historical records of past disposal activities and analytical results from sampling of the waste. A list of reports that discuss previous 
investigations performed at the quarry and surrounding area is presented in Table 4. This discussion of the known and suspected nature and extent of contamination at the quarry area is based upon these projections, previous surveys and investigations, and monitoring data collected as of the third quarter of 1992 (September). The nature and extent of contamination will be further defined as part of the RI phase of the QROU.

Monitoring and characterization data, collected by the Project Management Contractor, were entered into a computerized database referred to as the General Universal Report Utility (MK-Ferguson Company and Jacobs Engineering Group 1992b). This database is the source for all the radiological and chemical data summaries presented in the following sections. In general, standard field and laboratory methods were used in data collection. The detection limits used for laboratory analysis were the contract-required detection limits for Contract Laboratory Program (CLP) metals and the stated method detection limits for non-CLP metals and inorganic anions. For radionuclides and nitroaromatic compounds, several analytical methods were applied at various times during the characterization effort, resulting in a range of detection limits (DOE 1992a).

Earlier studies conducted to initially characterize site contamination and hydrogeology have also been considered, where appropriate. In accordance with the Environmental Data Administration Plan (MK-Ferguson Company and Jacobs Engineering Group 1992d), data that are entered into the database undergo a verification and validation process. However, this is an ongoing process, and verification and validation have not been completed for the data used in this work plan. In addition, it is not possible to verify or validate data collected prior to October 1989 because of the lack of documentation regarding quality assurance/quality control for these data. For this work plan, all data referred to in the discussion of the nature and extent of contamination are used qualitatively, except for those data that have been specifically rejected after undergoing verification and validation.

A review of the Cieneral Universal Report Utility database indicated that some of the concentrations measured in the groundwater and surface water appear to be outside the historical range. The values in question have been included in the following discussions, pending verification and/or validation.

\subsubsection{Origin of Contamination}

The Weldon Spring quarry was used for disposal of radioactively and chemically contaminated materials by the Army and the AEC. From 1942 to 1957, the quarry was used by the Army as a dumping area for TNT and DNT process wastes and for disposal of contaminated process residues and building rubble from the decommissioning of the Weldon Spring Ordnance Works. Under the AEC, wastes were disposed of in the quarry that originated from the Weldon Spring feed materials plant (chemical plant), which - from 1957 to 1966 - processed an average of $14,000 t$ (16,000 tons) of uranium material per year to produce uranium trioxide, uranium tetrafluoride and uranium metal. The raw material received at the plant was yellowcake (natural uranium); in addition, small amounts of thorium ore 
TABLE 4 Summary of Data Collection Activities at the Weldon Spring Quarry and Vicinity

\begin{tabular}{|c|c|c|c|c|c|}
\hline \multirow[b]{2}{*}{ Property/Medium } & \multicolumn{2}{|c|}{ Radiological Characterization } & \multicolumn{2}{|c|}{ Chemical Characterization } & \multirow[b]{2}{*}{ Reference } \\
\hline & Sampling Program & Analytical Porametero & Sampling Program & Analytical Parameter & \\
\hline \multicolumn{6}{|r|}{ Berkeley Geosciences } \\
\hline Soil & $\begin{array}{l}\text { Surface and sutsurface } \\
\text { samples from quarry floor, } \\
\text { piles, and quarry sump, } \\
8 \text { boreholes }\end{array}$ & $\begin{array}{l}\text { Gamma exposure rates, total } \\
\text { uranium, radium-226, } \\
\text { radium-228, and thorium }\end{array}$ & Not applicable & Not applicable & $\begin{array}{l}\text { Berkeley Geosciences } \\
\text { Aesociates (1984) }\end{array}$ \\
\hline Soil & Not applicable & Not applicable & $\begin{array}{l}3 \text { surface samples from } \\
\text { northeastern corner }\end{array}$ & $\begin{array}{l}\text { Nitroaromatic com- } \\
\text { pounds }\end{array}$ & $\begin{array}{l}\text { DOE (1990a); Meyer } \\
\text { (1988) }\end{array}$ \\
\hline Soil & $\begin{array}{l}81 \text { gamma exposure rate } \\
\text { measurements and gamma } \\
\text { logging at } 20 \text { boreholes (1979 } \\
\text { through 1981) }\end{array}$ & Count rates & Not applicable & Not applicable & DOE (1989) \\
\hline Soil & $\begin{array}{l}57 \text { surface and } 93 \text { subsurface } \\
\text { samples (1984) }\end{array}$ & Radium-226 and radium-228 & $\begin{array}{l}6 \text { subeurface and } 1 \text { surface } \\
\text { sample (1984) }\end{array}$ & $\begin{array}{l}\text { RCRA characteristics, } \\
\text { EP toricity, metals, } \\
\text { pesticides, volatiles, } \\
\text { semivolatiles, PAHs, } \\
\text { PCBs, and asbestos }\end{array}$ & DOE (1989) \\
\hline Soil & Not applicable & Not applicable & $\begin{array}{l}88 \text { samples from } \\
17 \text { boringe (1986) }\end{array}$ & $\begin{array}{l}\text { Volatiles, somivolatilea, } \\
\text { PCBs, and nitro- } \\
\text { aromatic compounds }\end{array}$ & DOE (1989) \\
\hline Soil & $\begin{array}{l}\text { Beta-gamma dose rate } \\
\text { measurements and } \\
55 \text { gamma exposure rate } \\
\text { measurements and gamma } \\
\text { logging of } 75 \text { boreholes using } \\
\text { NaI gamma scintillometer } \\
\text { (1984 through 1983) }\end{array}$ & Count ratee & Not applicable & Not applicable & DOE (1989) \\
\hline Soil & $\begin{array}{l}257 \text { surface and } 90 \text { subsur- } \\
\text { face samples with } 85 \text { surface } \\
\text { and } 51 \text { subsurface samples } \\
\text { analyzed for thorium-230 }\end{array}$ & $\begin{array}{l}\text { Uranium-238, radium-226, } \\
\text { radium-228, thorium-230 }\end{array}$ & Not applicable & Not applicable & DOE (1989) \\
\hline
\end{tabular}


TABLE 4 (Cont.)

\begin{tabular}{|c|c|c|c|c|c|}
\hline \multirow[b]{2}{*}{ Property/Medium } & \multicolumn{2}{|c|}{ Radiological Characterization } & \multicolumn{2}{|c|}{ Chemical Characterization } & \multirow[b]{2}{*}{ Reference } \\
\hline & Sampling Program & Analytical Parameters & Sampling Program & Analytical Parameters & \\
\hline \multicolumn{6}{|l|}{ Quarry (Cont.) } \\
\hline Soil & $\begin{array}{l}\text { Gamma scans and field } \\
\text { moasurements of subsurface } \\
\text { samples in } 12 \text { augered holes } \\
\text { in area of northeast corner } \\
\text { bench and rim of quarry }\end{array}$ & $\begin{array}{l}\text { Total uranium, radium-226, } \\
\text { radium-228, and thorium }\end{array}$ & Not applicable & Not applicable & $\begin{array}{l}\text { Berkeley Geosciencen } \\
\text { Aneociates (1984) }\end{array}$ \\
\hline Groundwater & $\begin{array}{l}\text { Samples from } 10 \text { monitoring } \\
\text { wells (1987) }\end{array}$ & $\begin{array}{l}\text { Total uranium, radium-226, } \\
\text { radium-228, thorium-230, } \\
\text { and thorium-232 }\end{array}$ & $\begin{array}{l}\text { Samples from } 10 \text { monitor- } \\
\text { ing wolls (1987) }\end{array}$ & $\begin{array}{l}\text { Metals, nitroaromatic } \\
\text { compounds, inorganic } \\
\text { anions, volatiles, } \\
\text { and peoticiles, PCB, } \\
\text { and }\end{array}$ & $\begin{array}{l}\text { MK-Ferguson Company } \\
\text { (1987) }\end{array}$ \\
\hline Surface water & $\begin{array}{l}\text { Samples from eight locations } \\
\text { (1987) }\end{array}$ & $\begin{array}{l}\text { Total uranium, radium-226, } \\
\text { radium-228, thorium-230, } \\
\text { thorium-232, groses alpha, } \\
\text { groses beta }\end{array}$ & $\begin{array}{l}\text { Samples from } 8 \text { locations } \\
\text { (1987) }\end{array}$ & $\begin{array}{l}\text { Metale, inorganic } \\
\text { aniona }\end{array}$ & $\begin{array}{l}\text { MK-Forgueon Company } \\
\text { (1987) }\end{array}$ \\
\hline \multicolumn{6}{|l|}{ Quarry and Vicinity } \\
\hline Soil & $\begin{array}{l}\text { Quarterly monitoring of } \\
\text { gamma radiation (1987-1991) }\end{array}$ & Gamma exposure rates & Not applicable & Not applicable & $\begin{array}{l}\text { MK-Ferguson Company } \\
\text { and Jacobs Engincering } \\
\text { Group (1988, 1989a, } \\
\text { 1990a, 1991a, 1992c) }\end{array}$ \\
\hline Groundwater & $\begin{array}{l}\text { Annual groundwater } \\
\text { monitoring (1987-1991) }\end{array}$ & $\begin{array}{l}\text { Total uranium, radium-226, } \\
\text { thorium-230, and } \\
\text { thorium-232 }\end{array}$ & $\begin{array}{l}\text { Annual groundwater } \\
\text { monitoring }\end{array}$ & $\begin{array}{l}\text { Inorganic anions, nitro- } \\
\text { aromatic compounds }\end{array}$ & $\begin{array}{l}\text { MK-Forgueon Company } \\
\text { and Jacobs Engineering } \\
\text { Group (1988, 1989a, } \\
\text { 1990a, 1991a, 1992c) }\end{array}$ \\
\hline Surface water & $\begin{array}{l}\text { Quarterly environmental } \\
\text { monitoring (1987) }\end{array}$ & $\begin{array}{l}\text { Total uranium, radium-226, } \\
\text { thorium-230, and } \\
\text { thorium-232 }\end{array}$ & Not applicable & Not applicable & $\begin{array}{l}\text { MK-Ferguson Company } \\
\text { and Jacobs Engineering } \\
\text { Group (1988) }\end{array}$ \\
\hline Surface water & $\begin{array}{l}\text { Quarterly environmental } \\
\text { monitoring }(1988,1989)\end{array}$ & $\begin{array}{l}\text { Total uranium, radium-226, } \\
\text { thorium-230, and } \\
\text { thorium-232 }\end{array}$ & $\begin{array}{l}\text { Quarterly environmental } \\
\text { monitoring (1988) }\end{array}$ & Inorganic anions & $\begin{array}{l}\text { MK-Fergueon Company } \\
\text { and Jacobe Engineering } \\
\text { Group (1989a, 1990a) }\end{array}$ \\
\hline Surface water & $\begin{array}{l}\text { Quarterly environmental } \\
\text { monitoring.(1990, 1991) }\end{array}$ & Total uranium & $\begin{array}{l}\text { Quarterly environmental } \\
\text { monitoring (1990) }\end{array}$ & $\begin{array}{l}\text { Inorganic anions, } \\
\text { nitroaromatic } \\
\text { compounds }\end{array}$ & $\begin{array}{l}\text { MK-Fergueon Company } \\
\text { and Jacobs Engineering } \\
\text { Group (1991a, 1992c) }\end{array}$ \\
\hline
\end{tabular}


TABLE 4 (Cont.)

\begin{tabular}{|c|c|c|c|c|c|}
\hline \multirow[b]{2}{*}{ Property/Medium } & \multicolumn{2}{|c|}{ Radiological Characterization } & \multicolumn{2}{|c|}{ Chemical Characterization } & \multirow[b]{2}{*}{ Reference } \\
\hline & Sampling Program & Analytical Parameters & Sampling Program & Analytical Parameters & \\
\hline \multicolumn{6}{|l|}{$\begin{array}{l}\text { Quarry and Vicinity } \\
\text { (Cont.) }\end{array}$} \\
\hline Air & $\begin{array}{l}\text { Quarterly radon gas } \\
\text { monitoring (1987-1991) }\end{array}$ & Radon & Not applicable & Not applicable & $\begin{array}{l}\text { MK-Ferguson Company } \\
\text { and Jacobs Engineering } \\
\text { Group (1988, 1989a, } \\
\text { 1990a, 1991a, 1992c) }\end{array}$ \\
\hline Air & $\begin{array}{l}\text { Quarterly particulates } \\
\text { monitoring (1989-1991) }\end{array}$ & $\begin{array}{l}\text { Radioactive particulates } \\
\text { (gross alpha) }\end{array}$ & Not applicable & Not applicable & $\begin{array}{l}\text { MK-Ferguson Company } \\
\text { and Jacobs Engineering } \\
\text { Group (1990a, 1991a, } \\
\text { 1992c) }\end{array}$ \\
\hline \multicolumn{6}{|c|}{ Quarry and Quarry Pond } \\
\hline Surface water & $\begin{array}{l}7 \text { water samples from quarry } \\
\text { boreholes and } 6 \text { samples from } \\
\text { quarry pond (1979) }\end{array}$ & Total uranium & $\begin{array}{l}10 \text { water samples from } \\
\text { boreholes and surface } \\
\text { waters (September 1979) }\end{array}$ & $\begin{array}{l}\text { Metals, inorganic } \\
\text { anions }\end{array}$ & $\begin{array}{l}\text { Berkeley Geosciences } \\
\text { Associates (1984) }\end{array}$ \\
\hline \multicolumn{6}{|c|}{ Slough and Quarry Pond } \\
\hline $\begin{array}{l}\text { Sediment and surface } \\
\text { water }\end{array}$ & $\begin{array}{l}\text { Surface and near-surface } \\
\text { samples from } 17 \text { locations } \\
\text { (1975 through 1979) }\end{array}$ & Total uranium & Not applicable & Not applicable & $\begin{array}{l}\text { Berkeley Gocsciences } \\
\text { Associates (1984) }\end{array}$ \\
\hline $\begin{array}{l}\text { Groundwater and } \\
\text { surface water }\end{array}$ & $\begin{array}{l}\text { Water samples from } 6 \text { wells, } \\
1 \text { sample from quarry pond, } \\
2 \text { samples from Upper } \\
\text { Femme Osage Slough, } \\
2 \text { samples from Lower } \\
\text { Femme Osage Slough, and } \\
10 \text { samples from Little } \\
\text { Femme Osage Creek (May } \\
1975 \text { to May 1979) }\end{array}$ & Total uranium & Not applicable & Not applicable & $\begin{array}{l}\text { Berkeley Geoscionces } \\
\text { Aseociates (1984) }\end{array}$ \\
\hline Invertebrates & $\begin{array}{l}\text { Samples from Little Femme } \\
\text { Osage Creek, Femme Osage } \\
\text { Slough, and downstream and } \\
\text { upstream from the quarry } \\
\text { (May and June 1991) }\end{array}$ & $\begin{array}{l}\text { Bioaceumulation of total } \\
\text { uranium }\end{array}$ & Not applicable & Not applicable & $\begin{array}{l}\text { MK-Ferguson Company } \\
\text { and Jacobs Engineering } \\
\text { Group (1992c) }\end{array}$ \\
\hline
\end{tabular}


TABLE 4 (Cont.)

\begin{tabular}{|c|c|c|c|c|c|}
\hline \multirow[b]{2}{*}{ Property/Medium } & \multicolumn{2}{|c|}{ Radiological Characterization } & \multicolumn{2}{|c|}{ Chemical Characterization } & \multirow[b]{2}{*}{ Reference } \\
\hline & Sampling Program & Analytical Parameters & Sampling Program & Analytical Parameters & \\
\hline \multicolumn{6}{|l|}{$\begin{array}{l}\text { Slough and Quarry } \\
\text { Pond (Cont.) }\end{array}$} \\
\hline Fish & $\begin{array}{l}\text { Samples from Femme Osage } \\
\text { Slough (May 1991) }\end{array}$ & $\begin{array}{l}\text { Bioaccumulation of total } \\
\text { uranium }\end{array}$ & Not applicable & Not applicable & $\begin{array}{l}\text { MK-Ferguson Company } \\
\text { and Jacobs Engineering } \\
\text { Group (1992c) }\end{array}$ \\
\hline $\begin{array}{l}\text { Surface water and } \\
\text { sediment }\end{array}$ & $\begin{array}{l}\text { Samples from Little Femme } \\
\text { Osage Creek and Femme } \\
\text { Osage Slough }\end{array}$ & $\begin{array}{l}\text { Uranium-238, radium-226, } \\
\text { thorium-232, gross alpha, } \\
\text { gross beta }\end{array}$ & Not applicable & Not applicable & Boerner (1986) \\
\hline $\begin{array}{l}\text { Surface water and } \\
\text { sediment }\end{array}$ & $\begin{array}{l}\text { Samples from Little Femme } \\
\text { Osage Creek and Femme } \\
\text { Osage Slough }\end{array}$ & Total uranium & $\begin{array}{l}\text { Samples from Little } \\
\text { Femme Osage Creek and } \\
\text { Femme Osage Slough }\end{array}$ & Metals, nitroaromatics & $\begin{array}{l}\text { MK-Ferguson Company } \\
\text { and Jacobe Engineering } \\
\text { Group (1991c, 1992b) }\end{array}$ \\
\hline Sediment & $\begin{array}{l}\text { Samples from Femme Osage } \\
\text { Slough }\end{array}$ & $\begin{array}{l}\text { Total uranium, thorium-230, } \\
\text { thorium-232 }\end{array}$ & Not applicable & Not applicable & $\begin{array}{l}\text { MK-Ferguson Company } \\
\text { and Jacobe Engineering } \\
\text { Group (1989b) }\end{array}$ \\
\hline \multicolumn{6}{|l|}{ Quarry Pond } \\
\hline Sediment & $\begin{array}{l}4 \text { sediment samples and } \\
1 \text { core sample }\end{array}$ & Total uranium & 5 sediment samples (1986) & $\begin{array}{l}\text { Semivolatiles, nitro- } \\
\text { aromatic compounds, } \\
\text { and PCBs (5 samples); } \\
\text { volatiles (2 samples) }\end{array}$ & $\begin{array}{l}\text { MK-Ferguson Company } \\
\text { and Jacobe Engineering } \\
\text { Group (1989a) }\end{array}$ \\
\hline Sediment & 3 sediment samples & $\begin{array}{l}\text { Uranium-234, uranium-235, } \\
\text { uranium-238, radium-226, } \\
\text { thorium-230, thorium-232, } \\
\text { and actinium-228 }\end{array}$ & Not applicable & Not applicable & $\begin{array}{l}\text { MK-Ferguson Company } \\
\text { and Jacobs Engineering } \\
\text { Group (1989a) }\end{array}$ \\
\hline Sediment & Not applicable & Not applicable & $\begin{array}{l}\text { Grab samples at } \\
2 \text { locations (1984); } \\
2 \text { additional samples } \\
\text { (1986) }\end{array}$ & $\begin{array}{l}\text { Metals, pesticides, } \\
\text { PCBs, and asbestos } \\
\text { Priority and nonpriority } \\
\text { pollutants }\end{array}$ & $\begin{array}{l}\text { MK-Ferguson Company } \\
\text { and Jacobs Engineering } \\
\text { Group (1989a) }\end{array}$ \\
\hline \multicolumn{6}{|l|}{ Near the quarry } \\
\hline Soil & Not applicable & Not applicable & $\begin{array}{l}1 \text { soil sample near } \\
\text { monitoring well TW-N, } \\
\text { north of quarry (1986) }\end{array}$ & $\begin{array}{l}\text { Volatiles, semivolatiles, } \\
\text { PCBs, and nitro- } \\
\text { aromatic compounds }\end{array}$ & $\begin{array}{l}\text { MR-Ferguson Company } \\
\text { and Jacobe Engineering } \\
\text { Group (1989a) }\end{array}$ \\
\hline Surface water & $\begin{array}{l}\text { Quarterly environmental } \\
\text { monitoring }\end{array}$ & Radionuclides & $\begin{array}{l}\text { Quarterly environmental } \\
\text { monitoring }\end{array}$ & $\begin{array}{l}\text { Inorganic anions and } \\
\text { metals }\end{array}$ & $\begin{array}{l}\text { MK-Ferguson Company } \\
\text { and Jacobs Engineering } \\
\text { Group (1989a) }\end{array}$ \\
\hline
\end{tabular}




\section{TABLE 4 (Cont.)}

\begin{tabular}{|c|c|c|c|c|c|}
\hline \multirow[b]{2}{*}{ Property/Medium } & \multicolumn{2}{|c|}{ Radiological Characterization } & \multicolumn{2}{|c|}{ Chemical Characterization } & \multirow[b]{2}{*}{ Reference } \\
\hline & Sampling Program & Analytical Parameters & Sampling Program & Analytical Parameters & \\
\hline \multicolumn{6}{|l|}{ Outside the Quarry } \\
\hline Soil & $\begin{array}{l}36 \text { surface and near-surface } \\
\text { samples from } 10 \text { borehole } \\
\text { locations using NaI detector }\end{array}$ & Radium-226 & Not applicable & Not applicable & $\begin{array}{l}\text { Berkeley Geosciences } \\
\text { Aseociates (1984) }\end{array}$ \\
\hline Soil & $\begin{array}{l}48 \text { surface and near-surface } \\
\text { samples from } 16 \text { borehole } \\
\text { locations using Ge-crystal } \\
\text { detector }\end{array}$ & Total uranium & Not applicable & Not applicable & $\begin{array}{l}\text { Berkeley Geoeciences } \\
\text { Associates (1984) }\end{array}$ \\
\hline Soil & $\begin{array}{l}44 \text { gamma exposure measure- } \\
\text { ments and surface soil } \\
\text { samples collected from } \\
4 \text { shallow boreholes at } 20-m \\
\text { grid intervals }\end{array}$ & $\begin{array}{l}\text { Gamma exposure rates, sur- } \\
\text { face beta-gamma dose rates, } \\
\text { uranium-238, radium-226, } \\
\text { and thorium-232 }\end{array}$ & Not applicable & Not applicable & Boerner (1986) \\
\hline Soil & 15 boreholes & Uranium-238 & Not applicable & Not applicable & Marutzky et al. (1988) \\
\hline Sediment & $\begin{array}{l}10 \text { locations at Femme Osage } \\
\text { Slough }\end{array}$ & $\begin{array}{l}\text { Total uranium, thorium-232, } \\
\text { thorium-230 }\end{array}$ & Not applicable & Not applicable & $\begin{array}{l}\text { MK-Fergueon Company } \\
\text { and Jacobs Engineering } \\
\text { Group (1989a) }\end{array}$ \\
\hline Groundwater & $\begin{array}{l}\text { Samples taken at } 41 \text { bore- } \\
\text { holes (1979 to 1981) }\end{array}$ & Total uranium & $\begin{array}{l}\text { Samples taken at } 27 \text { bore- } \\
\text { holes and from the quarry } \\
\text { pond (1979 to 1981) }\end{array}$ & $\begin{array}{l}\text { Metals, inorganic } \\
\text { anions }\end{array}$ & $\begin{array}{l}\text { Bertroley Geosciences } \\
\text { Anesciates (1984) }\end{array}$ \\
\hline Surface water & $\begin{array}{l}36 \text { samples from Femme } \\
\text { Osage Slough, Little Femme } \\
\text { Osage Creek, Femme Osage } \\
\text { Creek, and the Missouri } \\
\text { River }\end{array}$ & Total uranium & Not applicable & Not applicable & $\begin{array}{l}\text { Berkeley Geosciences } \\
\text { Aleociates (1984) }\end{array}$ \\
\hline Surface water & 6 samples near quarry & Groses alpha, grose beta & Not applicable & Not applicable & $\begin{array}{l}\text { MK-Parguson Company } \\
\text { and Jacoba Finginearing } \\
\text { Group (1989a) }\end{array}$ \\
\hline Surface water & $\begin{array}{l}\text { Samples from } 3 \text { locations } \\
\text { within } 1.6 \text { to } 11.2 \mathrm{~km} \text { ( } 1 \text { to } \\
7 \mathrm{mi} \text { ) of quarry }\end{array}$ & $\begin{array}{l}\text { Total uranium, uranium-234, } \\
\text { uranium-235, uranium-238, } \\
\text { radium-226, radium-228, } \\
\text { thorium-230, and } \\
\text { actinium-238 }\end{array}$ & Not applicable & Not applicable & $\begin{array}{l}\text { MR-Ferguwon Company } \\
\text { and Jacoba Enginoering } \\
\text { Group (1989a) }\end{array}$ \\
\hline
\end{tabular}


TABLE 4 (Cont.)

\begin{tabular}{|c|c|c|c|c|c|}
\hline \multirow[b]{2}{*}{ Property/Medium } & \multicolumn{2}{|c|}{ Radiological Characterization } & \multicolumn{2}{|c|}{ Chemical Characterization } & \multirow[b]{2}{*}{ Roforence } \\
\hline & Sampling Program & Analytical Parameters & Sampling Program & Analytical Parameters & \\
\hline \multicolumn{6}{|c|}{ Haulage Ways to the Quarry } \\
\hline Waste material & $\begin{array}{l}6 \text { surface samples from } \\
\text { gravel access road and rail } \\
\text { spur between Route } 94 \text { and } \\
\text { security fence enclosing } \\
\text { quarry }\end{array}$ & $\begin{array}{l}\text { Total uranium, radium-226, } \\
\text { radium-228, thorium }\end{array}$ & Not applicable & Not applicable & $\begin{array}{l}\text { Berteley Geomciences } \\
\text { Aneociates (1984) }\end{array}$ \\
\hline \multicolumn{6}{|l|}{$\begin{array}{l}\text { St. Charles County } \\
\text { Well Field }\end{array}$} \\
\hline Groundwater & $\begin{array}{l}\text { Samples from } 27 \text { monitoring } \\
\text { wells (May } 1985 \text { to June } \\
\text { 1985) }\end{array}$ & Groses alpha, grows beta & $\begin{array}{l}\text { Samples from } 27 \text { monitor- } \\
\text { ing wells (May } 1985 \text { to } \\
\text { June 1985) }\end{array}$ & $\begin{array}{l}\text { Metals, inorganic } \\
\text { anions }\end{array}$ & $\begin{array}{l}\text { Layne Weotern Company } \\
\text { (1986) }\end{array}$ \\
\hline Groundwater & $\begin{array}{l}\text { Samples from } 4 \text { monitoring } \\
\text { wells (1987) }\end{array}$ & $\begin{array}{l}\text { Total uranium, radium-226, } \\
\text { radium-228, thorium-230, } \\
\text { thorium-232, gross alpha, } \\
\text { gross beta }\end{array}$ & $\begin{array}{l}\text { Samples from } 4 \text { monitor- } \\
\text { ing wells (1987) }\end{array}$ & $\begin{array}{l}\text { Metale, inorganic } \\
\text { anions, and water } \\
\text { quality }\end{array}$ & $\begin{array}{l}\text { MK-Ferguson Company } \\
\text { (1987) }\end{array}$ \\
\hline Air & $\begin{array}{l}\text { Two batches of track etch } \\
\text { detectors: first batch in } \\
15 \text { augered holes (late } \\
\text { September to early October } \\
\text { 1979); second batch in } \\
14 \text { local soil and fill locations } \\
\text { in October } 1979 \\
\text { Total } 134 \text { laboratory } \\
\text { spectrometric analyses }\end{array}$ & Radon and thoron & Not applicable & Not applicable & $\begin{array}{l}\text { Berteley Geosciences } \\
\text { Associates (1984) }\end{array}$ \\
\hline
\end{tabular}

a Notation: EP = extraction procedure; Ge = germanium; NaI = sodium iodide; $P A H=$ polycyclic aromatic hydrocarbon; PCB = polychlorinated biphenyl; RCRA = Resource Conservation and Recovery Act. 
concentrates were also processed. Waste from the chemical plant included processing waste, equipment, and building rubble generated from decommissioning activities. A large quantity of radioactively contaminated waste from other areas was also disposed of in the quarry. The disposal activities, waste types, and estimated volumes are summarized in Table 5.

An estimated $73,000 \mathrm{~m}^{3}\left(95,000 \mathrm{yd}^{3}\right)$ of contaminated material is present in the quarry - of which approximately $31,000 \mathrm{~m}^{3}\left(40,000 \mathrm{yd}^{3}\right)$ is rubble, $39,000 \mathrm{~m}^{3}\left(51,000 \mathrm{yd}^{3}\right)$ is soil and clay, and $3,000 \mathrm{~m}^{3}\left(4,000 \mathrm{yd}^{3}\right)$ is pond sediment (DOE 1987). The radioactive contaminants in the quarry are those associated with the uranium-238, uranium-235, and thorium-232 decay series. The chemical contaminants associated with the waste material include nitroaromatic compounds, metals, volatile organic compounds (VOCs), semivolatile organic compounds, polychlorinated biphenyls (PCBs), and pesticides.

The characterization and monitoring data collected in the quarry area (as of September 1992) are summarized in Sections 2.4.2 through 2.4.7. The discussion is separated into media: soil, surface water, sediment, air, agricultural crops, and groundwater.

\subsubsection{Soil}

\subsubsection{Radioactive Contaminants}

A preliminary radiological survey of soil in the vicinity of the quarry area was performed by Oak Ridge Associated Universities (ORAU) in 1984-1985 (Boerner 1986). As part of this study, background radionuclide concentrations were measured at six locations within a $35-\mathrm{km}(22-\mathrm{mi})$ radius of the Weldon Spring site. The ranges of concentrations measured at these locations were 0.55 to $0.98 \mathrm{pCi} / \mathrm{g}$ for radium-226, 0.95 to $1.48 \mathrm{pCi} / \mathrm{g}$ for thorium-232, and $<0.68$ to $1.62 \mathrm{pCi} / \mathrm{g}$ for uranium-238.

The ORAU study consisted of a surface walkover scan of soils in the quarry area. Gamma exposure rate measurements and soil samples were taken at a minimum of every $100 \mathrm{~m}$ (300 $\mathrm{ft}$ ) over the scanned area; soil samples were also collected at locations identified during the walkover scan that had gamma exposure rates elevated above background levels. Soil samples were measured for uranium-238, radium-226, thorium-230, and thorium-232. Three contaminated vicinity properties were identified from this preliminary survey and were designated as vicinity properties 6,8 , and 9 (Boerner 1986). The locations of the properties are shown in Figure 10.

Vicinity property 6 is a localized area (i.e., 0.00021 ha $[0.00052$ acre]) of contamination adjacent to the quarry perimeter fence, which probably resulted from a spill during disposal activities at the quarry. This property was addressed as part of the RI/FS-EIS for the chemical plant area (DOE 1992a, 1992b, 1992c, 1992d, 1993). Vicinity property 8 was remediated in 1990, during construction activities for the quarry staging area. It consisted of three discrete areas located along a former railroad near a bridge over Little Femme Osage 
TABLE 5 History of Disposal Activities at the Weldon Spring Quarry

\begin{tabular}{|c|c|c|c|}
\hline \multirow[b]{2}{*}{ Time Period } & \multirow[b]{2}{*}{ Waste Type } & \multicolumn{2}{|c|}{$\begin{array}{l}\text { Estimated } \\
\text { Volume }^{\mathrm{a}}\end{array}$} \\
\hline & & $\mathrm{m}^{3}$ & $\mathrm{yd}^{3}$ \\
\hline $1942-1945$ & TNT and DNT process waste (burn areas) & - & - \\
\hline 1946 & TNT and DNT process waste (burn areas) & b & b \\
\hline $1946-1957$ & $\begin{array}{l}\text { TNT and DNT residues and contaminated rubble } \\
\text { from cleanup of the ordnance works (in deepest } \\
\text { part and in northeast corner of quarry) }\end{array}$ & - & - \\
\hline 1959 & $\begin{array}{l}3.8 \% \text { thorium residues (drummed, currently below } \\
\text { water level) }\end{array}$ & 150 & 200 \\
\hline $1960-1963$ & $\begin{array}{l}\text { Uranium- and radium-contaminated rubble from } \\
\text { demolition of the St. Louis Destrehan Street feed } \\
\text { plant (covering } 0.4 \text { ha [ } 1 \text { acre] to a } 9-\mathrm{m} \text { [30-ft] } \\
\text { depth in deepest part of quarry) }\end{array}$ & 38,000 & 50,000 \\
\hline $1963-1965$ & $\begin{array}{l}\text { High-thorium-content waste (in northeast corner of } \\
\text { quarry) }\end{array}$ & 760 & 1,000 \\
\hline $1963-1966$ & $\begin{array}{l}\text { Uranium and thorium residues from the chemical } \\
\text { plant and off-site facilities; building rubble and } \\
\text { process equipment (both drummed and } \\
\text { uncontained) }\end{array}$ & - & - \\
\hline 1966 & $\begin{array}{l}\text { 3.0\% thorium residues (drummed, placed above } \\
\text { water level in northeast corner of quarry); TNT } \\
\text { residues from cleanup of the ordnance works } \\
\text { (placed to cover the drums) }\end{array}$ & 460 & 600 \\
\hline $1968-1969$ & $\begin{array}{l}\text { Uranium- and thorium-contaminated rubble and } \\
\text { equipment from interiors of some chemical plant } \\
\text { buildings }(101,103 \text {, and } 105)\end{array}$ & 4,600 & 6,000 \\
\hline
\end{tabular}

a A hyphen indicates that the waste volume estimate is not available.

b An estimated 90 tons of TNT/DNT waste was burned in 1946.

c This was a portion of the waste originally stored at the Army Arsenal in Granite City, Illinois; most of this material was subsequently removed from the quarry for the purpose of recovering rare earth elements.

Sources: Data from Lenhard et al. (1967); Pennak (1975); Weidner and Boback (1982); Bechtel National (1983); Berkeley Geosciences Associates (1984); Kleeschulte and Emmett (1986); U.S. Nuclear Regulatory Commission (1988); DOE (1989). 


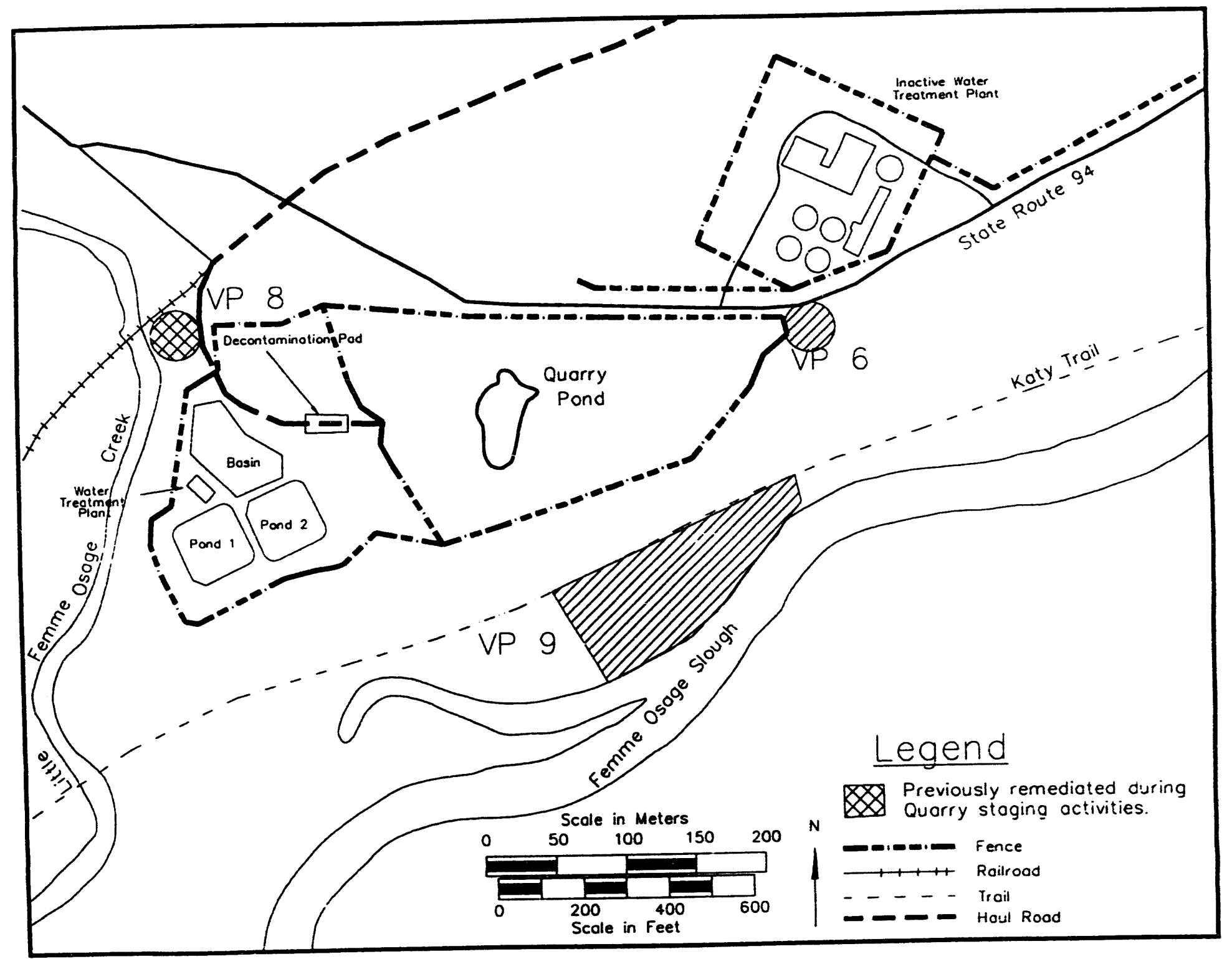

FIGURE 10 Locations of Vicinity Properties 6, 8, and 9 
Creek. Railroad cars were washed in this area after leaving the quarry. A final verification for the remediation of this area will be included as part of the QROU. Detailed descriptions of vicinity properties 6 and 8 are included in the RI for the chemical plant area (DOE 1992d).

Vicinity property 9 is located in the Missouri River floodplain, between Katy Trail and Femme Osage Slough (Figure 10). The data collected during two studies of vicinity property 9 (Boerner 1986; Marutzky et al. 1988) are summarized in Table 6. In the ORAU study (Boerner 1986), surface soil samples were collected on a $20-\mathrm{m}$ (65-ft) grid, and the samples were analyzed for uranium-238, radium-226, and thorium-232. Surface soil samples were also collected from six locations identified during the walkover scan; at four of these locations, shallow boreholes were drilled to a maximum depth of $0.75 \mathrm{~m}(2.3 \mathrm{ft})$. Collecting samples below this depth was limited by the shallow groundwater table, which was approximately $1 \mathrm{~m}(3 \mathrm{ft})$ from the ground surface at the time of sampling. Concentrations

TABLE 6 Summary of Soil Characterization Data for Vicinity Property $9^{\text {a }}$

\begin{tabular}{|c|c|c|c|c|c|}
\hline \multirow[b]{2}{*}{$\begin{array}{l}\text { Parameter/ } \\
\text { Depth } \\
\text { Interval }^{b} \\
\text { (m) }\end{array}$} & \multicolumn{2}{|c|}{ ORAU Studyc } & \multicolumn{2}{|c|}{ UNC Geotech Study } & \multirow{2}{*}{$\begin{array}{c}\text { Range of } \\
\text { Detection } \\
\text { Limits } \\
\left.(\mathbf{p C i})_{\mathbf{g}}\right)\end{array}$} \\
\hline & $\begin{array}{l}\text { Detection } \\
\text { Frequency }\end{array}$ & $\begin{array}{c}\text { Concentration } \\
\text { Range }^{d} \\
\text { (pCi/g) }\end{array}$ & $\begin{array}{l}\text { Detection } \\
\text { Frequency }\end{array}$ & $\begin{array}{c}\text { Concentration } \\
\text { Range } \\
\text { (pCi/g) }\end{array}$ & \\
\hline Radium-226 & & & & & $0.2 \cdot 1.5$ \\
\hline $0-0.3$ & $52 / 52$ & $0.31-1.6$ & $2 / 2$ & $0.8-1.2$ & \\
\hline $0.3-0.75$ & $3 / 4$ & $0.45-1.4$ & $2 / 2$ & 1.1 & \\
\hline Thorium-232 & & & & & $0.10-1.5$ \\
\hline $0-0.3$ & $45 / 52$ & $0.17-3.0$ & $2 / 2$ & $1.3-1.5$ & \\
\hline $0.3-0.75$ & $2 / 4$ & $0.92-1.6$ & $2 / 2$ & $1.2-1.7$ & \\
\hline Uranium-238 & & & & & $0.30-3.0$ \\
\hline $0-0.3$ & $45 / 52$ & $0.3-890$ & $15 / 15$ & $0.3-110$ & \\
\hline $0.3-0.9^{f}$ & $4 / 4$ & $87-700$ & $26 / 27$ & $0.30-49$ & \\
\hline $0.9-1.5$ & - & - & $24 / 26$ & $0.70-49$ & \\
\hline $1.5-3.0$ & - & - & $54 / 58$ & $0.70-60$ & \\
\hline $3.0-6.0$ & - & - & $66 / 74$ & $0.30-93$ & \\
\hline $6.0-8.0$ & - & - & $10 / 13$ & $0.30-4.0$ & \\
\hline
\end{tabular}

a Vicinity property 9 is located directly south of the quarry between Katy Trail and Femme Osage Slough (Figure 10).

b Includes all soil samples collected within the specified depth interval.

c Source: Boerner (1986); background concentrations in soil measured for this study were 0.55$0.98 \mathrm{pCi} / \mathrm{g}$ for radium-226, 0.95-1.48 $\mathrm{pCi} / \mathrm{g}$ for thorium-232, and $<0.68-1.62 \mathrm{pCi} / \mathrm{g}$ for uranium-238.

d Concentration range for detected values only.

- Source: Marutzky et al. (1988); the average background concentration in soil measured for this study was $1.2 \mathrm{pCi} / \mathrm{g}$ for radium-226, thorium-232, and uranium-238.

f Depth interval is $0.3-0.75 \mathrm{~m}$ for the ORAU study. 
of radium-226 and thorium-232 were not elevated above background levels. Uranium-238 concentrations ranged from background to $890 \mathrm{pCi} / \mathrm{g}$.

Further characterization of vicinity property 9 was performed by UNC Geotech (Marutzky et al. 1988). The study consisted of sampling 13 boreholes located north of the slough and 2 boreholes south of the slough. For comparison, background samples were collected from an $8-\mathrm{km}(5-\mathrm{mi})$ radius around the chemical plant area; average background concentrations of radium-226, thorium-232, and uranium-238 were all $1.2 \mathrm{pCi} / \mathrm{g}$ (Marutzky et al. 1988). The borehole samples were collected in $0.3-\mathrm{m}$ (1-ft) increments; the depth of individual boreholes varied from 1.9 to $11 \mathrm{~m}(6.3$ to $36 \mathrm{ft})$. At the time of sampling, the

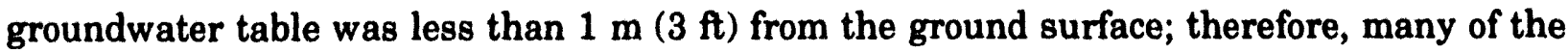
samples collected were a mixture of groundwater and soil. Each sample was analyzed for uranium-238; surface soil samples from two boreholes located north of the slough were also analyzed for radium-226, thorium-230, and thorium-232. The maximum uranium-238 concentration detected was $110 \mathrm{pCi} / \mathrm{g}$ in a sample collected north of the slough in the uppermost $0.3 \mathrm{~m}(1 \mathrm{ft})$ of soil. Uranium concentrations greater than $10 \mathrm{pCi} / \mathrm{g}$ were detected in 11 of the boreholes to depths ranging from 1.8 to $5 \mathrm{~m}$ (6 to $16 \mathrm{ft}$ ). The limited number of samples analyzed for radium and thorium had concentrations similar to background levels. Although no soil samples were collected directly under the slough, the two boreholes drilled south of the slough did not indicate elevated levels of uranium.

As ancillary information, soil borings obtained from drilling groundwater monitoring wells MW-1030, MW-1031, and MW-1033 were composited in 0.6- or 3-m (2- or 10-ft) increments and analyzed for total uranium (MK-Ferguson Company and Jacobs Engineering Group 1992b). Wells MW-1030 and MW-1031 are located south of the quarry rim and well MW-1033 is located south of Femme Osage Slough (Section 2.4.7). Boreholes ranged from a depth of $6.5 \mathrm{~m}$ (20 ft) for MW-1031 and MW-1033 to $11 \mathrm{~m}$ (36 ft) for MW-1030. Total uranium concentrations did not exceed $10 \mathrm{pCi} / \mathrm{g}$; however, samples were composited and concentrations may be significantly higher over smaller intervals.

\subsubsection{Chemical Contaminants}

A comprehensive investigation has not been conducted for chemical contaminants in soil. The limited amount of data that has been collected is from four borings that resulted from drilling monitoring wells MW-1030, MW-1031, MW-1033, and MW-1034 (Section 2.4.7). Soil was composited in increments of 0.6 or $3 \mathrm{~m}(2$ or $10 \mathrm{ft}$ ) to a total depth of $15 \mathrm{~m} \mathrm{(45} \mathrm{ft)}$

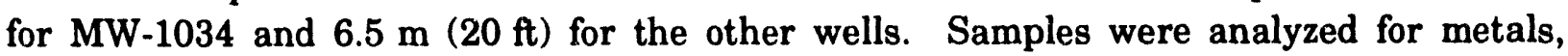
inorganic anions, and organic compounds, including specific nitroaromatic compounds (MK-Ferguson Company and Jacobs Engineering Group 1992b).

Concentrations of metals were initially compared with the ranges commonly found in soil; these ranges are listed in Table 2.4 of the baseline assessment (BA) for the chemical plant area (DOE 1992a). The results of the analysis indicate that, south of the quarry rim, concentrations of cadmium and magnesium are slightly elevated over typical background levels. In addition, three VOCs - acetone, methylene chloride, and toluene - were detected 
in trace concentrations (i.e., at no more than 69,28 , and $55 \mu \mathrm{g} / \mathrm{kg}$, respectively). No semivolatile organics, nitroaromatic compounds, or PCBs and pesticides were detected above their respective detection limits. The results of these analyses will be confirmed in the characterization to be performed during the RI phase for the QROU.

\subsubsection{Surface Water}

Surface water samples from Femme Osage Slough, Little Femme Osage Creek, Femme Osage Creek, and the Missouri River are routinely collected as part of the monitoring program for the Weldon Spring quarry (MK-Ferguson Company and Jacobs Engineering Group 1988, 1989a, 1990a, 1991a, 1992c, 1993a). The sampling program includes six locations along Femme Osage Slough, two locations along Little Femme Osage Creek (above and below the quarry), and one location in Femme Osage Creek. The pond quarry water is included as part of the monitoring program to identify contamination that may potentially migrate to groundwater. Four locations along the Missouri River are also monitored to provide preoperational baseline water quality data for operation of the quarry water treatment plant. The closest downstream sampling location along the Missouri River is about $1.6 \mathrm{~km}$ (1 mi) downstream of the confluence with Femme Osage Slough. The surface water monitoring locations are shown in Figure 11.

Characterization data for surface water in Femme Osage Slough and Little Femme Osage Creek have been collected as part of two separate investigations. In one investigation, radioactive contaminants were measured at two locations in Little Femme Osage Creek and Femme Osage Slough (Boerner 1986). In a biological screening investigation (MK-Ferguson Company and Jacobs Engineering Group 1991c, 1992b), total uranium and selected metals were measured at eight locations in Femme Osage Slough and two locations in Little Femme Osage Creek. The characterization data collected during these investigations, together with the monitoring data, are summarized in Table 7.

Although surface waters in nearby areas were not specifically sampled to determine background concentrations, data are available from a separate investigation in which springs and streams were sampled in the nearby conservation areas to assess potential contaminant migration from the chemical plant area (MK-Ferguson Company and Jacobs Engineering Group 1989c). Additional data collected from uncontaminated surface waters in the Busch

Conservation Area (Dardenne Creek and Lake 10) are also available (Ryckman/Edgerley/ Tomlinson \& Associates 1978; MK-Ferguson Company 1987); these data are presented in Table 2.11 of the BA for the chemical plant area (DOE 1992a).

\subsubsection{Radioactive Contaminants}

Total uranium has been measured quarterly as part of the surface water monitoring program, and selected locations have been measured for gross alpha, gross beta, radium-226, 


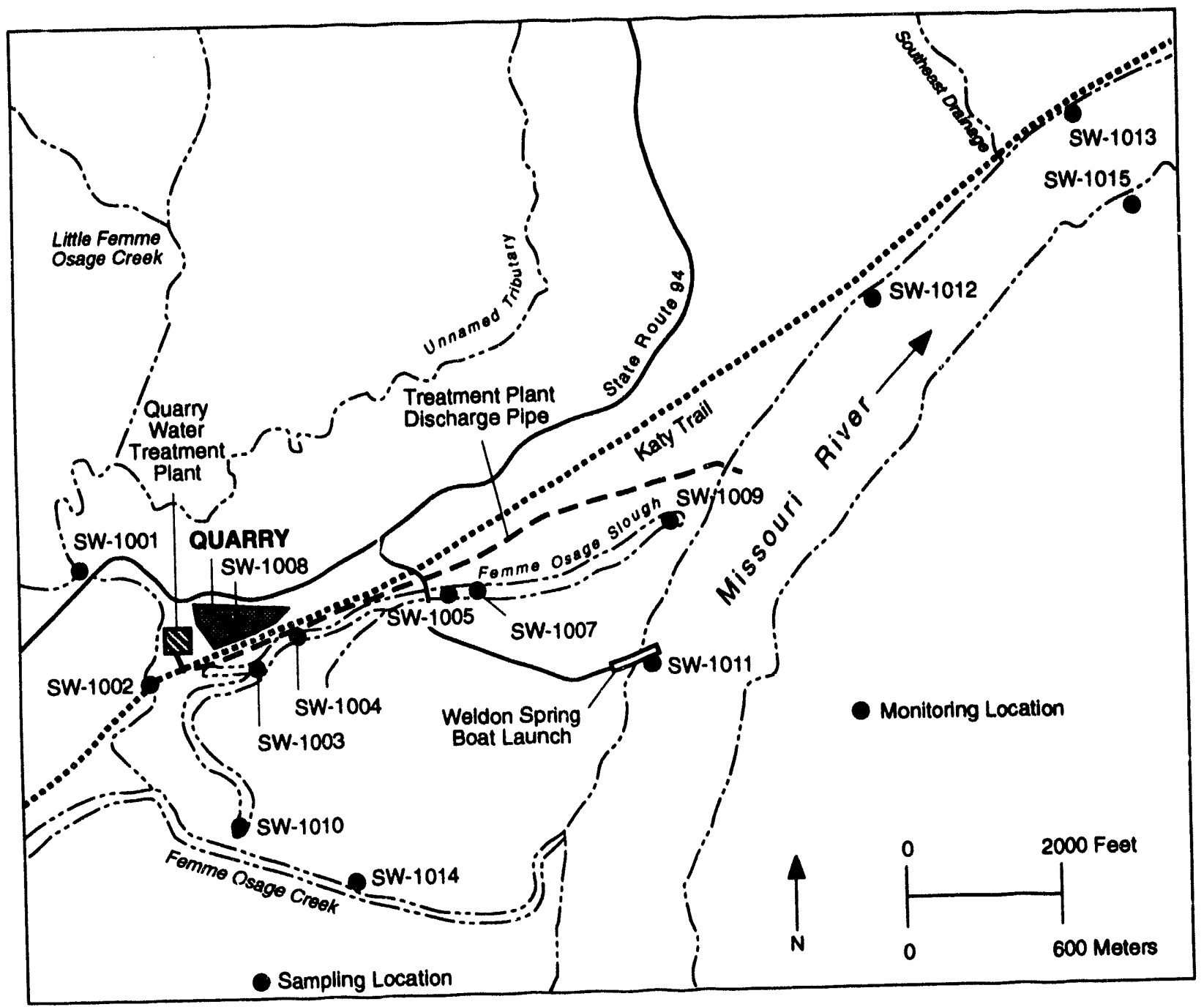

FIGURE 11 Surface Water Monitoring Locations

radium-228, thorium-228, thorium-230, and thorium-232. Data have also been collected from Femme Osage Slough and Little Femme Osage Creek as part of two separate investigations (Boerner 1986; MK-Ferguson Company and Jacobs Engineering Group 1991c, 1992b).

Except for uranium, all analytes were measured at concentrations similar to those of the uncontaminated surface water bodies (i.e., Dardenne Creek and Lake 10). Slightly elevated levels of radium-226 and thorium-230 were detected in Little Femme Osage Creek, but these samples were collected upstream of the quarry (SW-1001). Elevated levels of total uranium have been consistently measured in Femme Osage Slough, although large variations in concentrations have been reported. The slough is generally stagnant but is allowed to fill through a valve during high water conditions in the Missouri River. Fluctuating water levels in the slough could affect contaminant concentrations. The highest uranium concentrations have been measured directly adjacent to the quarry (SW-1004). 
TABLE 7 Summary of Surface Water Data

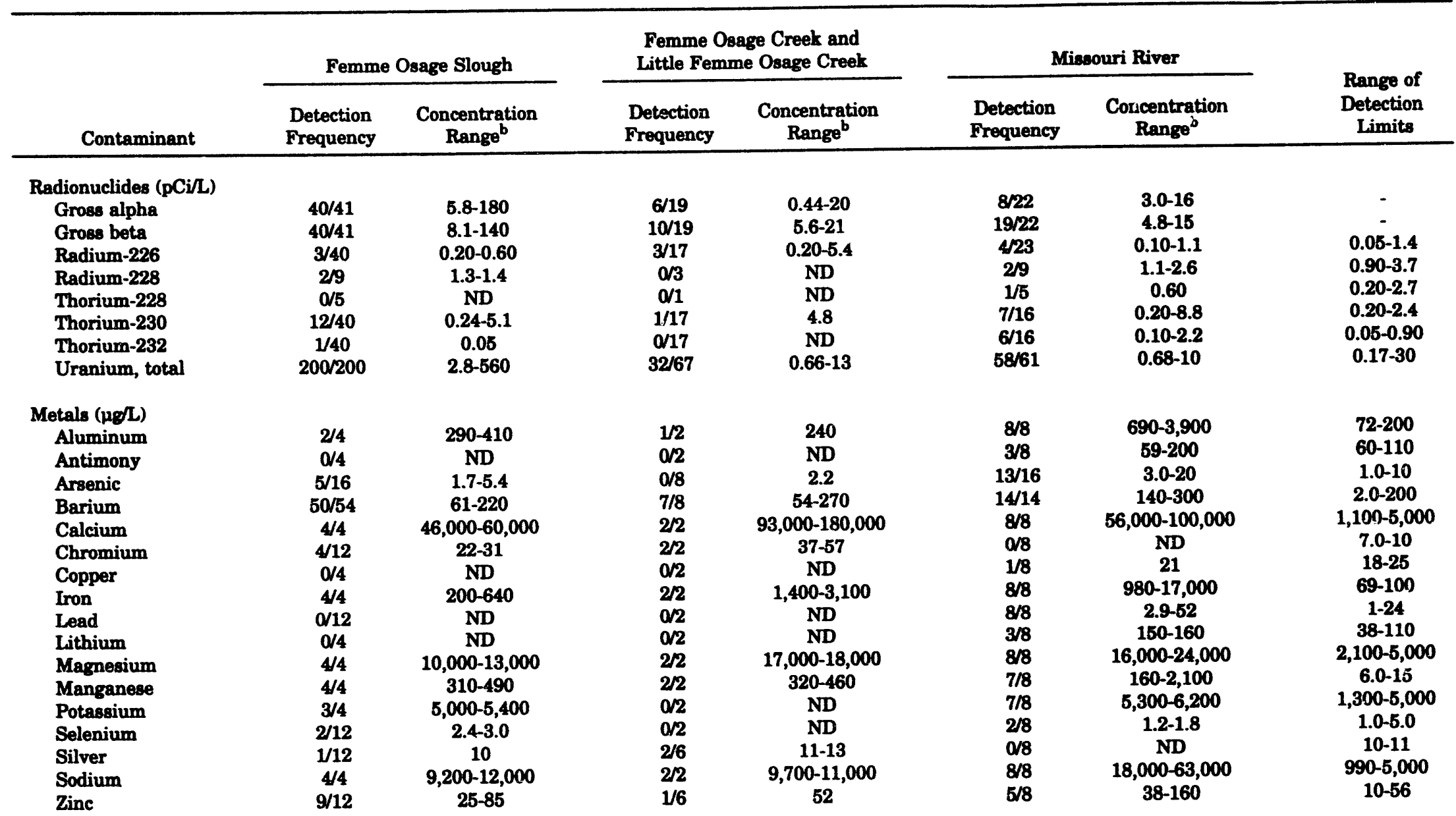


TABLE 7 (Cont.)

\begin{tabular}{|c|c|c|c|c|c|c|c|}
\hline \multirow[b]{2}{*}{ Contaminant } & \multicolumn{2}{|c|}{ Femme Osage Slough } & \multicolumn{2}{|c|}{$\begin{array}{l}\text { Femme Osage Creek and } \\
\text { Little Femme Osage Creek }\end{array}$} & \multicolumn{2}{|c|}{ Missouri River } & \multirow{2}{*}{$\begin{array}{c}\text { Range of } \\
\text { Detection } \\
\text { Limits }\end{array}$} \\
\hline & $\begin{array}{l}\text { Detection } \\
\text { Frequency }\end{array}$ & $\begin{array}{c}\text { Concentration } \\
\text { Range }^{b}\end{array}$ & $\begin{array}{l}\text { Detection } \\
\text { Frequency }\end{array}$ & $\begin{array}{c}\text { Concentration } \\
\text { Range }^{\mathbf{b}}\end{array}$ & $\begin{array}{l}\text { Detection } \\
\text { Frequency }\end{array}$ & $\begin{array}{l}\text { Concentration } \\
\text { Range }^{b}\end{array}$ & \\
\hline \multicolumn{8}{|c|}{ Inorganic anions (mg/L) } \\
\hline Chloride & $48 / 48$ & 4.4-14 & $21 / 21$ & $3.9-11$ & $17 / 17$ & $8-38$ & $0.020-0.25$ \\
\hline Fluoride & $18 / 40$ & $0.30-0.60$ & $6 / 17$ & $0.33-0.5$ & $12 / 17$ & $0.30-0.83$ & $0.010-0.25$ \\
\hline Nitrate-N & $16 / 53$ & $0.14-9.9$ & $22 / 24$ & $0.17-8.9$ & $20 / 20$ & $0.69-13$ & $0.10-0.20$ \\
\hline Nitrite-N & - & - & - & - & $4 / 4$ & $0.010-0.080$ & 0.010 \\
\hline Sulfate & $46 / 46$ & $32-290$ & $20 / 20$ & $22-270$ & $19 / 19$ & $37-170$ & $0.030-40$ \\
\hline \multicolumn{8}{|l|}{$\begin{array}{l}\text { Nitroaromatic } \\
\text { compounds ( } \mu / \mathrm{L})\end{array}$} \\
\hline 2,4-DNT & $0 / 12$ & ND & $1 / 5$ & 0.037 & $\mathbf{0 1 1}$ & ND & $0.030-0.050$ \\
\hline 2,6-DNT & 0/12 & ND & $1 / 5$ & 0.014 & $\mathbf{0} 11$ & ND & $0.010-0.60$ \\
\hline TNB & 0/11 & ND & $1 / 5$ & 0.04 & ov11 & ND & 0.030 \\
\hline 2,4,6-TNT & $0 / 12$ & ND & $\mathbf{1 / 5}$ & 0.067 & 0/11 & ND & $0.030-0.50$ \\
\hline
\end{tabular}

- In 1990 1991a), a study by Boerner (1986), and an aquatic screening investigation (MK-Ferguson Company and Jacobs Engineering Group 1991c, 1992b). Only 1990a, 1991a), a study by Boerner (1986), and an aquatic screening investigation (Mre-Ferguson Company and shown in Figure 11.

b Range of concentrations above the detection limit. ND indicates not detected; a hyphen indicates that the analysis was not performed for that contaminant. 


\subsubsection{Chemical Contaminants}

The surface water monitoring program has included routine monitoring for inorganic anions and a limited number of analyses for metals and nitroaromatic compounds. Additional characterization data have been collected for metals and inorganic anions in Femme Osage Slough and Little Femme Osage Creek (MK-Ferguson Company and Jacobs Engineering Group 1991c, 1992b). The levels of naturally occurring constituents (i.e., metals and inorganic anions) detected in Femme Osage Slough, Femme Osage Creek, and Little Femme Osage Creek appear to be typical of those of uncontaminated surface water bodies in the area. Low levels of nitroaromatic compounds were detected in Little Femme Osage Creek at a location upstream of the quarry (SW-1001).

\subsubsection{Sediment}

Sediment samples from Little Femme Osage Creek and Femme Osage Slough have been analyzed for radioactive and chemical contaminants (Boerner 1986; MK-Ferguson Company and Jacobs Engineering Group 1989b, 1989c, 1991c, 1992b); these data are summarized in Table 8. An appropriate background location was not specifically sampled as part of these characterization studies. For comparison, data are available for sediment in an uncontaminated lake (Lake 37) in the Busch Conservation Area (MK-Ferguson Company and Jacobs Engineering Group 1989c); these data are presented in Table 2.13 of the BA for the chemical plant area (DOE 1992a).

\subsubsection{Radioactive Contaminants}

Sediment samples from Femme Osage Slough and Little Femme Osage Creek were analyzed for radioactive contaminants as part of three separate investigations (Boerner 1986; MK-Ferguson Company and Jacobs Engineering Group 1989c, 1991c, 1992b). The major focus of these investigations was total uranium, but samples from selected locations were also analyzed for radium-226, thorium-230, and thorium-232. The results of these analyses indicate low levels of uranium contamination in Femme Osage Slough and Little Femme Osage Creek (upstream of the quarry). The limited amount of data collected for radium and thorium did not indicate levels exceeding those determined at Lake 37.

\subsubsection{Chemical Contaminants}

Sediment samples from Little Femme Osage Creek and Femme Osage Slough were analyzed for metals as part of the aquatic screening investigation (MK-Ferguson Company and Jacobs Engineering Group 1991c, 1992b) (Table 8). Samples from the slough were also analyzed for selected nitroaromatic compounds, but none were detected above the detection limits. Compared with the off-site uncontaminated lake, many of the metals were detected at elevated concentrations. Comparison with an appropriate background location, however, is needed before any conclusive evaluation can be made. 
TABLE 8 Summary of Sediment Data

\begin{tabular}{|c|c|c|c|c|c|}
\hline \multirow[b]{2}{*}{ Contaminant } & \multicolumn{2}{|c|}{ Femme Osage Slough } & \multicolumn{2}{|c|}{ Little Femme Osage Creek } & \multirow{2}{*}{$\begin{array}{c}\text { Range of } \\
\text { Detection } \\
\text { Limits }\end{array}$} \\
\hline & $\begin{array}{l}\text { Detection } \\
\text { Frequency }\end{array}$ & $\begin{array}{c}\text { Concentration } \\
\text { Range }^{b}\end{array}$ & $\begin{array}{l}\text { Detection } \\
\text { Frequency }\end{array}$ & $\begin{array}{c}\text { Concentration } \\
\text { Range }^{b}\end{array}$ & \\
\hline \multicolumn{6}{|c|}{ Radionuclides (pCi/g) } \\
\hline Radium-226 & $2 / 2$ & $0.34-0.71$ & $2 / 2$ & $0.42-1.0$ & $0.2-1.0$ \\
\hline Thorium-230 & $5 / 5$ & $1.1-1.9$ & - & - & 1.0 \\
\hline Thorium-232 & $5 / 5$ & $1.0-1.2$ & 2/2 & $0.54-1.2$ & 0.5 \\
\hline Uranium, total & $45 / 45$ & $0.30-13$ & $10 / 14$ & $0.76-9.0$ & $0.00030-1.0$ \\
\hline \multicolumn{6}{|l|}{ Metals ( $\mu \mathrm{g} / \mathrm{g}$ ) } \\
\hline Arsenic & $18 / 18$ & 2.7-12 & $12 / 12$ & $1.5-3.8$ & $0.10-1.3$ \\
\hline Barium & $18 / 18$ & $110-350$ & $12 / 12$ & $28-230$ & $1.2-4.1$ \\
\hline Cadmium & $1 / 18$ & 0.77 & $1 / 12$ & 1.3 & $0.30-2.4$ \\
\hline Chromium & $18 / 18$ & 3.3-50 & $12 / 12$ & 2.7-9.6 & $0.70-3.7$ \\
\hline Lead & $18 / 18$ & $15-44$ & $12 / 12$ & $3.2-15$ & $0.47-2.4$ \\
\hline Mercury & $3 / 18$ & $0.19-0.99$ & $0 / 12$ & ND & $0.020-0.16$ \\
\hline Selenium & $14 / 18$ & $0.61-2.2$ & $0 / 12$ & ND & $0.20-0.64$ \\
\hline Silver & $3 / 18$ & $0.60-0.67$ & $3 / 12$ & $1.5-2.1$ & $0.40-1.0$ \\
\hline Zinc & $18 / 18$ & $36-160$ & $12 / 12$ & $12-45$ & $2.4-5.0$ \\
\hline
\end{tabular}

a Includes a summary of data from Boerner (1986) and MK-Ferguson Company and Jacobs Engineering Group (1989c, 1992b, 1992i). Only those contaminants detected in at least one of the locations are reported.

b Range of concentrations above the detection limit. ND indicates not detected; a hyphen indicates that analysis was not performed for that contaminant.

\subsubsection{Air}

Radon, external gamma exposure rates, and radioactive air particulates are measured routinely as part of the ongoing environmental monitoring program (MK-Ferguson Company and Jacobs Engineering Group 1988, 1989a, 1990a, 1991a, 1992c, 1993a). Radon concentrations are measured quarterly at six locations along the quarry perimeter; Terradex Track Etch Type F detectors are used, which measure both radon-220 and radon-222. Background radon concentrations are measured at four off-site locations outside the area of influence: one in the Weldon Spring Conservation Area, two in the Busch Conservation Area, and one at the St. Charles County water treatment plant. Historically, levels of radon at the quarry have been statistically elevated (at the 95\% confidence interval) above background. Elevated radon concentrations at the quarry are due to the radium contamination present in the bulk waste. Radon concentrations are expected to decrease significantly after the bulk waste has been removed from the quarry.

Gamma radiation is measured quarterly with environmental thermoluminescent dosimeters at six locations along the quarry perimeter. Background gamma radiation is also monitored at the same four locations used for monitoring background radon concentrations. The results have shown that gamma exposure rates within the quarry are elevated compared 
with background levels. These levels are due to the gamma-emitting contamination contained in the bulk waste. It is anticipated that these levels will decrease significantly after the bulk waste has been removed.

Airborne radioactive particulates are measured at two monitoring locations on the northeastern and southern perimeters of the quarry. Background concentrations are monitored at the Busch Conservation Area. Results of the monitoring program have shown that long-lived gross alpha concentrations are not statistically different (at the 95\% confidence limit) than background levels, which indicates that no airborne radioactivity has been released from the quarry.

\subsubsection{Agricultural Crops}

Much of the land in the alluvial floodplain south of Femme Osage Slough is used for agriculture. Both corn and soybeans are grown in this area as feed for livestock. Preliminary sampling of crops grown in the St. Charles County well field was conducted in 1991 and 1992 (MK-Ferguson Company and Jacobs Engineering Group 1993a). For analytical purposes, corn samples were separated into kernels, cobs, and husks/stalks. All samples were analyzed for radium-226, radium-228, thorium-228, thorium-230, thorium-232, and total uranium. Soil samples were also collected from each sampling location, and background samples for soil, corn, and soybeans were collected from a location west of Augusta; these samples were also analyzed for the same parameters. A comparison of data from the well field with data from the background location did not indicate biouptake of radionuclides.

\subsubsection{Groundwater}

The shallow groundwater system consists of two lithologically distinct units: bedrock at the quarry and alluvium near the Little Femme Osage Creek and between the quarry bluff and the Missouri River (Section 2.3.3.2). The shallow bedrock aquifer includes three Ordovician formations: the Kimmswick Limestone, Decorah Group, and Plattin Limestone, in descending order. In the area near the quarry, suspected pathways for groundwater flow are the joints and fractures (secondary porosity) in the upper bedrock. South of the quarry, groundwater flow is probably a combination of flow through porous media composed of alluvium and flow through fractures in the underlying limestone. Groundwater in the vicinity of the quarry has been, and continues to be, monitored to determine changes in water quality and/or contaminant levels. Currently, wells that are routinely monitored for the presence of radionuclide and chemical contaminants include 36 DOE monitoring wells (MW), four St. Charles County monitoring wells (RMW), and eight St. Charles County production wells (PW) (Figures 12 and 13).

The current groundwater monitoring system was designed to monitor specific vertical and horizontal regions of the aquifer. In the vertical direction, the wells can be classified on 


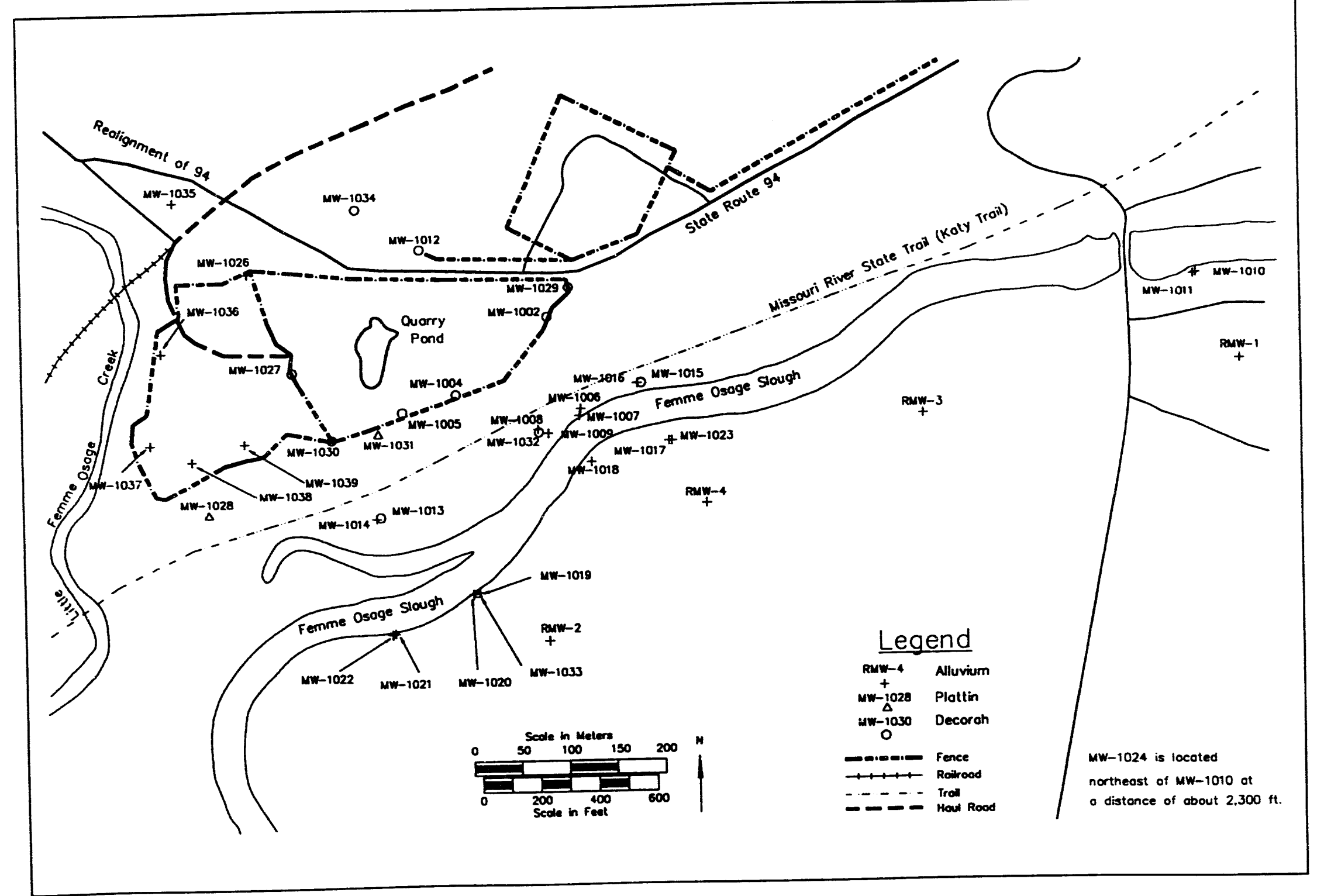




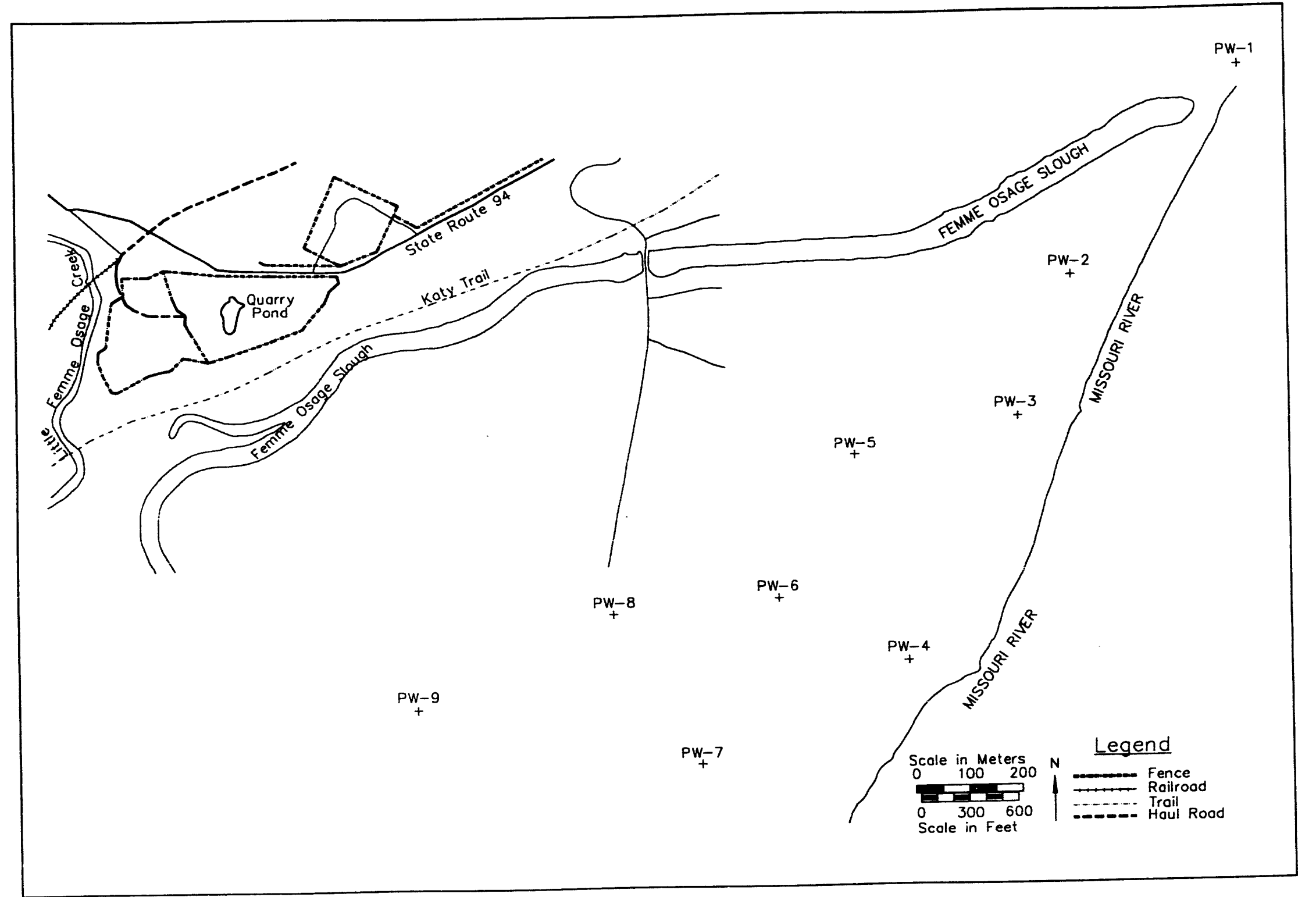


the basis of the formation in which they are screened. The monitoring network includes the following:

- Two wells screened across the Kimmswick Limestone and Decorah Group;

- Nine wells screened within the Decorah Group;

- One well screened across the lower Decorah Group and upper Plattin Limestone;

- Two wells screened within the Plattin Limestone;

- Six wells screened within the tributary alluvium; and

- Twenty wells screened within the Missouri River alluvium (Table 9).

Within the bedrock aquifer, the Kimmswick Limestone and Decorah Group appear to be interconnected by vertical joints and fractures (Section 2.3.3.2); thus, the wells screened across these two formations are grouped with the wells screened only within the Decorah Group. The well screened across the lower Decorah Group and upper Plattin Limestone, well MW-1028, was grouped with the wells completed within the Plattin Limestone because most of its screen is located within this formation.

Horizontally, within the quarry area, several general areas of the shallow groundwater system are monitored by a line or small cluster of wells (Table 9; Figures 12 and 13). These monitoring locations include the following:

- Tributary alluvium (associated with Little Femme Osage Creek) and Kimmswick Limestone/Decorah Group north of the quarry;

- Kimmswick Limestone/Decorah Group along the quarry rim;

- Decorah Group, Plattin Limestone, and Missouri River alluvium north of Femme Osage Sough;

- Plattin Limestone and Missouri River alluvium south of the slough; and

- Missouri River alluvium located approximately at the midpoint between Femme Osage Slough and the St. Charles County production wells.

In addition to these general areas, four compliance wells were completed in the tributary alluvium west of the quarry, primarily to monitor the equalization basin and effluent ponds associated with the quarry water treatment plant. Finally, each St. Charles County production well (PW-2 through PW-9) is also monitored to ensure that the potential source areas are not affecting the quality of the water within the well field. 


\section{TABLE 9 Monitoring Wells for the Quarry Area and the St. Charles County Well Field}

\begin{tabular}{|c|c|}
\hline $\begin{array}{l}\text { Kimmswick Limestone/ } \\
\text { Decorah Group }\end{array}$ & $\begin{array}{l}\text { Missouri River } \\
\text { Alluvium }\end{array}$ \\
\hline North of quarry & North of slough \\
\hline MW-1012 & MW-1006 \\
\hline \multirow{2}{*}{ MW-1034 } & MW-1007 \\
\hline & MW-1008 \\
\hline Along quarry rim & MW-1009 \\
\hline MW-1002 & MW-1014 \\
\hline MW-1004 & MW-1016 \\
\hline \multicolumn{2}{|l|}{ MW-1005 } \\
\hline MW-1027 & South of slough \\
\hline MW-1029 & MW-1010 \\
\hline \multirow[t]{2}{*}{ MW-1030 } & MW-1011 \\
\hline & MW-1017 \\
\hline North of slough & MW-1018 \\
\hline$M W-1013$ & MW-1019 \\
\hline MW-1015 & MW-1020 \\
\hline \multirow[t]{2}{*}{ MW-1032 } & MW-1021 \\
\hline & MW-1022 \\
\hline Plattin Limestone & MW-1023 \\
\hline \multicolumn{2}{|l|}{ North of slough } \\
\hline $\mathrm{MW}-1028^{\mathrm{a}}$ & Midpoint between slough \\
\hline MW-1031 & and well field \\
\hline & RMW-1 \\
\hline South of slough & RMW-2 \\
\hline MW-1033 & RMW-3 \\
\hline & RMW-4 \\
\hline \multicolumn{2}{|l|}{ Tributary Alluvium } \\
\hline & St. Charles County \\
\hline North of quarry & well field \\
\hline MW-1026 & PW-2 \\
\hline \multirow[t]{2}{*}{ MW-1035 } & PW-3 \\
\hline & PW-4 \\
\hline West of quarry & PW-5 \\
\hline MW-1036 & PW-6 \\
\hline MW-1037 & PW-7 \\
\hline MW-1038 & PW-8 \\
\hline MW-1039 & PW-9 \\
\hline
\end{tabular}

a Screened across the lower Decorah Group and upper Plattin Limestone. 
The groundwater monitoring program in the quarry vicinity has been most active in the past 6 years (MK-Ferguson Company and Jacobs Engineering Group 1988, 1989a, 1990a, 1991a, 1992c, 1993a). In general, the program consists of sampling the entire monitoring well network and the St. Charles County production wells and analyzing the groundwater samples for radionuclides, metals, inorganic anions, and nitroaromatic compounds. The monitoring schedule in this area has often been modified as new wells have been installed and to accommodate new knowledge and the concerns of the public and regulatory agencies (MK-Ferguson Company and Jacobs Engineering Group 1992c).

As part of a Phase I water quality assessment (the first comprehensive chemical groundwater evaluation), monitoring wells in the quarry area were sampled in March 1987. These samples were analyzed for pesticides, PCBs, semiv latile organic compounds, and VOCs. No semivolatile compounds, PCBs, or pesticides were detected in any samples, but three VOCs - toluene, ethyl benzene, and xylene - were detected in two alluvial wells north of the slough (MK-Ferguson Company 1987). Subsequent quarterly sampling of these and other wells failed to detect these compounds (MK-Ferguson Company and Jacobs Engineering Group 1988). Details of the groundwater monitoring program for previous years, such as the sampling frequency and rationale, are presented in the various environmental monitoring plans and reports (MK-Ferguson Company 1987; MK-Ferguson Company and Jacobs Engineering Group 1988, 1989a, 1990a, 1990b, 1991a, 1991b, 1992a, 1992c, 1992f).

Groundwater samples have been collected and analyzed routinely for gross alpha, gross beta, radium-226, radium-228, thorium-230, thorium-232, and total uranium. In 1992, thorium-228, which is analyzed along with the other thorium isotopes, was also reported. Metals analyzed routinely include arsenic and barium, and samples from select wells have been analyzed at least once for various other metals. Inorganic anions included in the routine monitoring program are chloride, fluoride, nitrate, and sulfate; nitroaromatic compounds included are 1,3-dinitrobenzene (DNB), 2,4-DNT, 2,6-DNT, nitrobenzene (NB), 1,3,5-trinitrobenzene (TNB), and 2,4,6-TNT.

In addition to the monitoring program described above, groundwater samples have been collected and analyzed from wells completed within the alluvium upgradient of the quarry area. These data were collected as part of a separate study to determine a range of natural groundwater concentrations to compare with those concentrations measured within the alluvium at the quarry area. During 1988 and 1989, four groundwater samples were collected from a private water well that produces from the Missouri River alluvium and is located several kilometers upstream of the quarry and the St. Charles County well field; these samples were analyzed for several parameters, including total uranium. Although not a comprehensive study, results of the monitoring provided some background concentrations in the alluvium (MK-Ferguson Company and Jacobs Engineering Group 1992c).

In a more recent study, background groundwater samples were collected from the Missouri River alluvium and analyzed for major cations, metals, and radionuclide constituents. Four monitoring well clusters, consisting of a shallow and a deep well, were installed on a transect across the alluvium on the north side of the Missouri River near 
Defiance. Additional information on the monitoring well installation and sampling methodology are given in a USGS report (Kleeschulte 1993). In Sections 2.4.7.1 and 2.4.7.2, concentrations of groundwater contaminants detected in the QROU alluvium are compared with background concentrations measured in groundwater samples collected from these wells.

\subsubsection{Radioactive Contaminants}

The groundwater in the quarry area has been analyzed for gross alpha, gross beta, radium-226, radium-228, thorium-228, thorium-230, thorium-232, and total uranium. The vertical and horizontal extent of contamination have been evaluated from groundwater monitoring results: the vertical extent on the basis of well completion - i.e., either within the alluvium, Kimmswick Limestone/Decorah Group, or Plattin Limestone - and the horizontal extent on the basis of well location. The radioactive contaminants detected in the shallow groundwater system are summarized in Tables 10 and 11.

Background concentrations of radionuclides in the shallow bedrock have not been determined; consequently, it is difficult to distinguish natural background radioactivity from contamination migrating from the potential source areas (i.e., the quarry and/or Femme Osage Slough). In the Missouri River alluvium, background concentrations of gross alpha, gross beta, radium-226, radium-228, thorium-228, thorium-232, and total uranium were measured at two different upgradient locations (MK-Ferguson Company and Jacobs Engineering Group 1992c; Kleeschulte 1993). In the following discussion, the radionuclide concentrations detected in the alluvium are compared with the background values presented in Table 12; for uranium and radium, the maximum concentrations detected in groundwater are compared in Table 13 with EPA standards - e.g., maximum contaminant levels (MCLs) and maximum contaminant level goals (MCLGs) - under the Safe Drinking Water Act (EPA 1992).

The uranium concentrations detected in the shallow groundwater system ranged from 0.2 to $6,700 \mathrm{pCi} / \mathrm{L}$, with the higher concentrations measured within both the bedrock and the alluvium. The uranium concentrations in the shallow bedrock ranged from 0.3 to $6,300 \mathrm{pCi} / \mathrm{L}$. The highest uranium concentrations measured in the shallow bedrock (i.e., the Kimmswick Limestone/Decorah Group) were from wells MW-1004, MW-1005, and MW-1027 located along the rim of the quarry, and from wells MW-1013, MW-1015, and MW-1032 located north of Femme Osage Slough. The uranium concentrations measured in these two areas of the bedrock aquifer ranged from 0.68 to $6,300 \mathrm{pCi} / \mathrm{L}$; these concentrations are several orders of magnitude higher than the uranium concentrations measured within the bedrock north of the quarry, which ranged from 1.6 to $11 \mathrm{pCi} / \mathrm{L}$.

Uranium concentrations in the three wells screened within the upper Plattin Limestone ranged from 2.5 to $42 \mathrm{pCi} / \mathrm{L}$. The highest concentration in this lower formation was detected in groundwater samples from well MW-1031 south of the quarry. Uranium concentrations in the alluvium ranged from 0.2 to $6,700 \mathrm{pCi} / \mathrm{L}$. The highest concentrations were measured in groundwater samples from wells MW-1006, MW-1008, MW-1014, and 
TABLE 10 Summary of Groundwater Data for the Bedrock

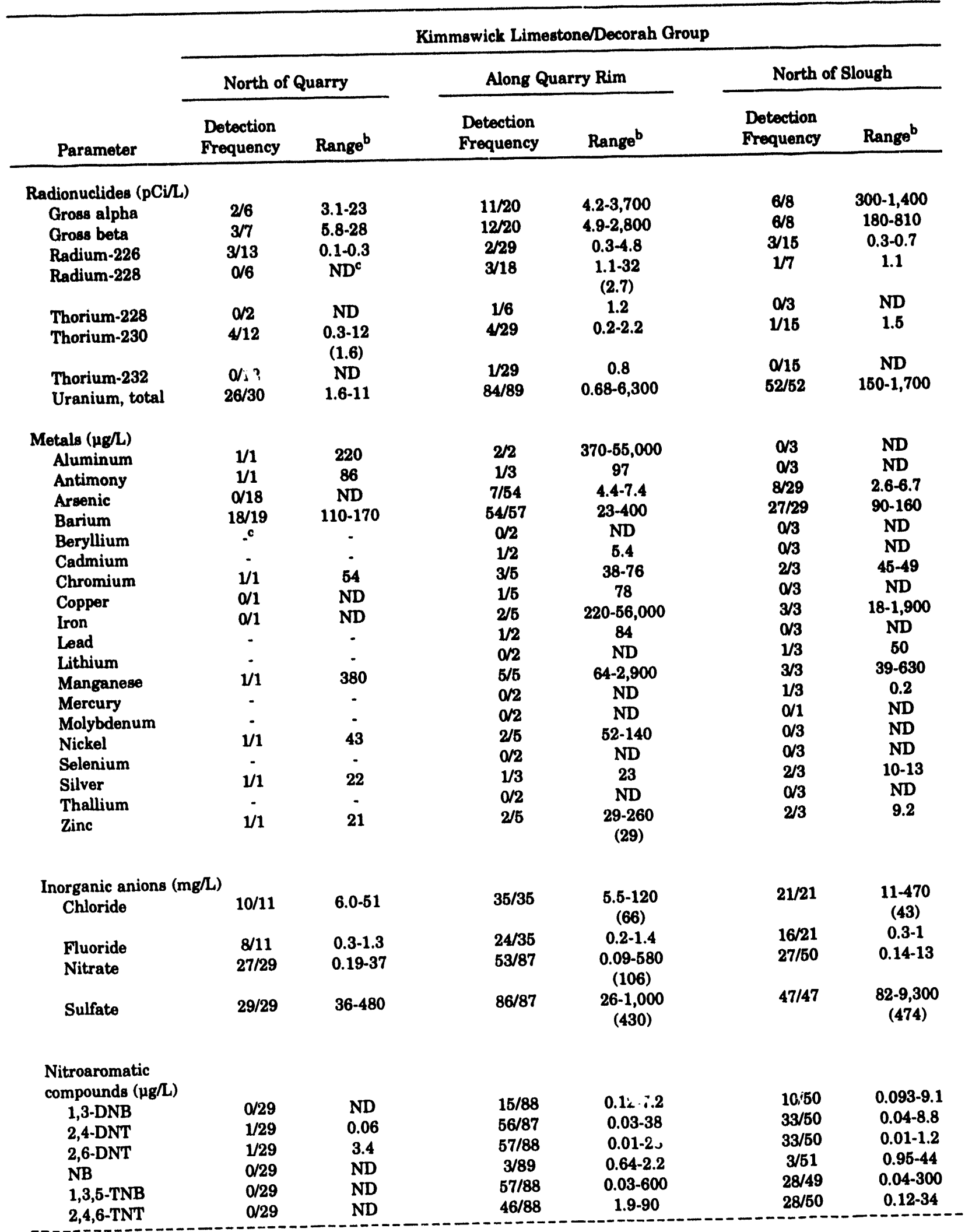


TABLE 10 (Cont.)

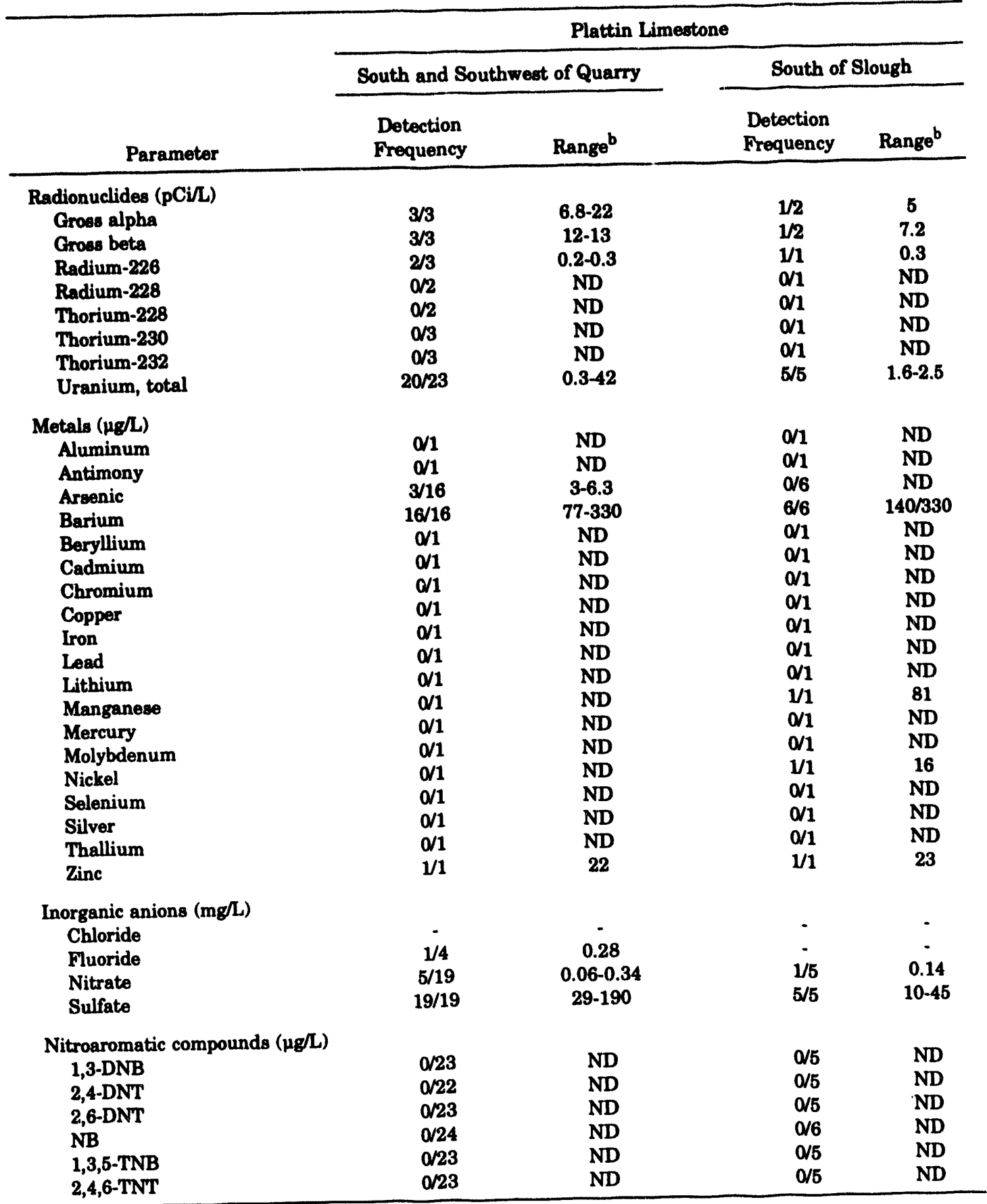

a The bedrock includes the Kimmswick Limestone/Decorah Group and the Plattin Limestone. The following wells were sampled in the Kimmswick/Decorah: north of quarry - wells MW-1012 and MW-1034; along quarry rim - wells MW-1002, MW-1004, MW-1005, MW-1027, MW-1029, and MW-1030; north of slough - wells MW-1013, MW-1015, and MW-1032. The following wells were sampled in the Plattin Limestone: south and southwest of quarry - wells MW-1028 and MW-1031; south of slough - well MW-1033.

b Range of concentrations above the detection limit. A value in parentheses is the next highest value below the high value indicated for the range; the high values in these cases are suspected outliers.

c ND indicates not detected; a hyphen indicates that analysis was not performed for that parameter. 
TABLE 11 Summary of Groundwater Data for the Alluvium

\begin{tabular}{|c|c|c|c|c|c|c|}
\hline \multirow[b]{2}{*}{ Parameter } & \multicolumn{2}{|c|}{ North of Quarry } & \multicolumn{2}{|c|}{ East of Quarry } & \multicolumn{2}{|c|}{$\begin{array}{c}\text { North of } \\
\text { Fomme Osage Slough }\end{array}$} \\
\hline & $\begin{array}{l}\text { Detection } \\
\text { Frequency }\end{array}$ & Range ${ }^{b}$ & $\begin{array}{l}\text { Detoction } \\
\text { Frequency }\end{array}$ & Range $^{b}$ & $\begin{array}{l}\text { Detection } \\
\text { Frequency }\end{array}$ & Range $^{b}$ \\
\hline \multicolumn{7}{|c|}{ Radionuclides (pCi/L) } \\
\hline Gross alpha & $1 / 2$ & 25 & $3 / 8$ & $3.9-8.5$ & $12 / 26$ & $26-6,000$ \\
\hline Gross beta & $2 / 2$ & $5.9-18$ & $6 / 8$ & 5.9.14 & $11 / 26$ & $11-3,400$ \\
\hline Radium-226 & $2 / 3$ & $0.2-0.4$ & $\therefore$ & $\cdot$ & $5 / 45$ & $0.2-3.7$ \\
\hline Radium-228 & $0 / 2$ & $\mathrm{ND}^{\mathrm{c}}$ & $0 / 4$ & ND & $0 / 20$ & ND \\
\hline Thorium-228 & $0 / 2$ & ND & $0 / 4$ & ND & $0 / 6$ & ND \\
\hline Thorium-230 & $0 / 3$ & ND & $1 / 4$ & 0.2 & $5 / 45$ & $0.3-3.4$ \\
\hline Thorium-232 & $0 / 3$ & ND & $0 / 4$ & ND & $1 / 45$ & 4.9 \\
\hline Uranium, total & $7 / 23$ & $0.3-2.5$ & $33 / 36$ & $0.68-38$ & $111 / 115$ & $1.4-6,700$ \\
\hline \multicolumn{7}{|l|}{ Metals ( $\mu \mathrm{g} / \mathrm{L}$ ) } \\
\hline Aluminum & - & - & $\mathbf{1} 4$ & 1,200 & $3 / 6$ & $200-260$ \\
\hline Antimony & - & - & $0 / 4$ & ND & $4 / 4$ & $77-82$ \\
\hline Arsenic & $9 / 16$ & $19-26$ & $4 / 48$ & $2.4-62$ & $18 / 51$ & $2.6-30$ \\
\hline Barium & $16 / 16$ & $200-420$ & $48 / 48$ & $\begin{array}{l}200-3,100 \\
(640)\end{array}$ & $52 / 66$ & 22.670 \\
\hline Beryllium & - & - & $\alpha / 4$ & ND & $1 / 2$ & 5 \\
\hline Cadmium & - & - & $0 / 4$ & ND & $2 / 2$ & 5 \\
\hline Chromium & - & - & $\mathbf{0 / 4}$ & ND & $4 / 4$ & $46-75$ \\
\hline Copper & - & - & $0 / 4$ & ND & $0 / 6$ & ND \\
\hline Iron & - & - & $3 / 4$ & $1,100-3,600$ & $6 / 6$ & $100-5,100$ \\
\hline Lead & - & - & $0 / 4$ & ND & 02 & ND \\
\hline Lithium & - & - & $0 / 4$ & ND & $2 / 2$ & 50 \\
\hline Manganese & - & - & 44 & $360-2,600$ & $6 / 6$ & $210-7,200$ \\
\hline Mercury & - & - & $0 / 4$ & ND & $2 / 2$ & 0.2 \\
\hline Molybdenum & - & - & $0 / 4$ & ND & 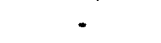 & - \\
\hline Nickel & - & - & $1 / 4$ & 11 & $1 / 6$ & 41 \\
\hline Selenium & - & - & $0 / 4$ & ND & $0 / 4$ & ND \\
\hline Silver & - & - & $0 / 4$ & ND & $5 / 6$ & $13-26$ \\
\hline Thallium & - & - & $0 / 4$ & ND & $0 / 2$ & ND \\
\hline Zine & - & - & $1 / 4$ & 23 & $3 / 6$ & $21-30$ \\
\hline \multicolumn{7}{|c|}{ Inorganic anions $(\mathbf{m g} / \mathbf{L})$} \\
\hline Chloride & $4 / 4$ & $2.0-4$ & - & - & $60 / 60$ & $8.6-450$ \\
\hline Fluoride & $1 / 4$ & 0.19 & - & - & $24 / 40$ & $0.19-1.2$ \\
\hline Nitrate & $5 / 20$ & $0.1-0.27$ & $11 / 44$ & $0.1-0.89$ & $67 / 112$ & $0.07-25$ \\
\hline Sulfate & $15 / 20$ & $0.64-67$ & $44 / 44$ & $9.8-82$ & $109 / 110$ & $\begin{array}{c}2.8-1,700 \\
(343)\end{array}$ \\
\hline \multicolumn{7}{|l|}{$\begin{array}{l}\text { Nitroaromatic } \\
\text { compounds }(\mu \mathrm{g} / \mathrm{L})\end{array}$} \\
\hline 1,3-DNB & $0 / 20$ & ND & $0 / 44$ & ND & $9 / 114$ & $0.14-0.34$ \\
\hline 2,4-DNT & $0 / 20$ & ND & $0 / 44$ & ND & $22 / 114$ & $0.03-6.4$ \\
\hline 2,6-DNT & $0 / 20$ & ND & $0 / 44$ & ND & 44114 & $0.01-7.4$ \\
\hline NB & $0 / 20$ & ND & $0 / 48$ & ND & $5 / 114$ & $0.7-7.6$ \\
\hline $1,3,5-$ TNB & $1 / 20$ & 0.16 & $0 / 44$ & ND & $46 / 114$ & $0.03-220$ \\
\hline $2,4,6-\mathrm{TNT}$ & $0 / 20$ & ND & $0 / 44$ & ND & $38 / 114$ & $0.09-43$ \\
\hline
\end{tabular}


TABLE 11 (Cont.)

\begin{tabular}{|c|c|c|c|c|c|c|}
\hline \multirow[b]{2}{*}{ Parameter } & \multicolumn{2}{|c|}{$\begin{array}{c}\text { South of } \\
\text { Femme Osage Slough }\end{array}$} & \multicolumn{2}{|c|}{$\begin{array}{l}\text { Midpoint between Femme } \\
\text { Osage Slough and Well Field }\end{array}$} & \multicolumn{2}{|c|}{ Well Field } \\
\hline & $\begin{array}{l}\text { Detection } \\
\text { Frequency }\end{array}$ & Range $^{b}$ & $\begin{array}{l}\text { Detection } \\
\text { Frequency }\end{array}$ & Range $^{b}$ & $\begin{array}{l}\text { Detection } \\
\text { Frequency }\end{array}$ & Range $^{b}$ \\
\hline \multicolumn{7}{|c|}{ Radionuclides (pCi/L) } \\
\hline Gross alpha & $20 / 60$ & $0.3-30$ & $24 / 62$ & $1-200$ & $31 / 108$ & $1-38$ \\
\hline Gross beta & $8 / 33$ & $1-22$ & $14 / 20$ & $2-11$ & $31 / 39$ & $1-8.6$ \\
\hline Radium-226 & $16 / 53$ & $0.2-2.6$ & $8 / 22$ & $0.1-0.8$ & $14 / 23$ & $0.3-4$ \\
\hline Radium-228 & $5 / 27$ & $1.1-3$ & 8/12 & $0.3-5.4$ & $14 / 23$ & $0.1-2.6$ \\
\hline Thorium-228 & $2 / 10$ & $0.15-0.23$ & $0 / 4$ & ND & $0 / 8$ & ND \\
\hline Thorium-230 & $10 / 54$ & $0.1-3.6$ & $7 / 22$ & $0.1-2$ & $4 / 23$ & $0.12-0.8$ \\
\hline Thorium-232 & $2 / 54$ & $0.2-1.6$ & $5 / 22$ & 0.1 & $3 / 23$ & $0.1-0.2$ \\
\hline Uranium & $60 / 195$ & $0.2-31$ & $54 / 73$ & $0.4-11$ & $33 / 109$ & $0.2-8.2$ \\
\hline \multicolumn{7}{|l|}{ Metals $(\mu \mathrm{g} / \mathrm{L})$} \\
\hline Aluminum & $0 / 5$ & ND & 0/14 & ND & - & - \\
\hline Antimony & $0 / 4$ & ND & $5 / 10$ & 60 & - & - \\
\hline Arsenic & $63 / 77$ & $3.6-170$ & $45 / 63$ & $4.1-62$ & $14 / 60$ & $2.3-4.9$ \\
\hline Barium & $76 / 78$ & $110-1,300$ & $60 / 65$ & $100-650$ & $60 / 60$ & 220-530 \\
\hline Beryllium & $1 / 4$ & 5 & $4 / 9$ & 5 & - & - \\
\hline Cadmium & $3 / 4$ & 6-12 & $0 / 9$ & ND & $0 / 23$ & ND \\
\hline Chromium & $6 / 6$ & $28-47$ & $8 / 13$ & 21-55 & - & - \\
\hline Copper & $1 / 6$ & 65 & $\mathbf{1} 13$ & 29 & - & - \\
\hline Iron & $7 / 7$ & $880-26,000$ & $13 / 16$ & $20-12,000$ & - & - \\
\hline Lead & $0 / 4$ & ND & $4 / 9$ & $7.8-20$ & $3 / 23$ & $2.7-4.9$ \\
\hline Lithium & $4 / 4$ & 50 & $4 / 9$ & 50 & - & - \\
\hline Manganese & $7 / 7$ & $500-5,900$ & $16 / 16$ & $82-2,100$ & - & - \\
\hline Mercury & $4 / 4$ & 0.2 & $4 / 9$ & 0.2 & $2 / 23$ & $0.26-0.33$ \\
\hline Molybdenum & $1 / 1$ & 15 & $4 / 8$ & $12-22$ & - & - \\
\hline Nickel & $0 / 4$ & ND & $2 / 12$ & 40 & - & - \\
\hline Selenium & $0 / 4$ & ND & $0 / 4$ & ND & - & - \\
\hline Silver & $2 / 4$ & 10 & $3 / 12$ & $10-23$ & - & - \\
\hline Thallium & $0 / 4$ & ND & $0 / 9$ & ND & - & - \\
\hline Zinc & $5 / 6$ & $20-38$ & $6 / 14$ & $20-73$ & - & - \\
\hline \multicolumn{7}{|l|}{$\begin{array}{l}\text { Inorganic anions } \\
(\mathbf{m g} / \mathrm{L})\end{array}$} \\
\hline Chloride & $88 / 88$ & $\begin{array}{l}2.5-530 \\
(70)\end{array}$ & $36 / 36$ & $1.5-18$ & $10 / 10$ & $2.1-18$ \\
\hline Fluoride & $51 / 86$ & $0.1-6.8$ & $14 / 32$ & $0.18-0.37$ & $0 / 7$ & ND \\
\hline Nitrate & $19 / 150$ & $\begin{array}{l}0.01-3,400 \\
\quad(2.4)\end{array}$ & $15 / 58$ & $\begin{array}{l}0.2-3,000 \\
(5.8)\end{array}$ & $0 / 31$ & ND \\
\hline Sulfate & $93 / 153$ & $\begin{array}{l}0.41-12,000 \\
(935)\end{array}$ & $58 / 61$ & $2.7-340$ & $24 / 24$ & $12-130$ \\
\hline \multicolumn{7}{|l|}{$\begin{array}{l}\text { Nitroaromatic } \\
\text { compounds }(\mu \mathrm{g} / \mathrm{L})\end{array}$} \\
\hline 1,3-DNB & $0 / 166$ & ND & $1 / 76$ & 0.23 & $0 / 115$ & ND \\
\hline 2,4-DNT & $4 / 166$ & $0.31-0.51$ & $5 / 75$ & $0.08-0.54$ & $8 / 114$ & $0.06-1.5$ \\
\hline 2,6-DNT & $2 / 166$ & $0.8-5.2$ & $2 / 76$ & $0.27-1.2$ & $2 / 115$ & $0.24-2.2$ \\
\hline NB & $2 / 172$ & $0.37-1.0$ & $1 / 89$ & 0.21 & $1 / 138$ & 0.31 \\
\hline $1,3,5-\mathrm{TNB}$ & $19 / 166$ & $\begin{array}{l}0.02-160 \\
(0.79)\end{array}$ & $3 / 75$ & $0.06-0.08$ & $6 / 114$ & $0.02-0.06$ \\
\hline $2,4,6-\mathrm{TNT}$ & $3 / 166$ & $0.01-51$ & $1 / 76$ & 1.1 & $1 / 114$ & 1.9 \\
\hline
\end{tabular}

a The alluvium includes the QROU and the St. Charles County well field. The following wells were sampled: north of quarry, wells MW-1026 and MW-1035; east of quarry, wells MW-1036, MW-1037, MW-1038, and MW-1039; north of Femme Osage Slough, wells MW-1006, MW-1007, MW-1008, MW-1009, MW-1014, and MW-1016; south of Femme Osage Slough, wells MW-1010, MW-1011, MW-1017, MW-1018, MW-1019, MW-1020, MW-1021, MW-1022, MW-1023, and MW-1024; midpoint between the slough and well field, wells RMW-1, RMW-2, RMW-3, and RMW-4; in the well field, wells PW-2, PW-3, PW-4, PW-5, PW-6, PW-7, PW-8, and PW-9.

b Range of concentrations above the detection limit. A value in parentheses is the next highest value below the high value indicated for the range; the high values in these cases are suspected outliers.

c ND indicates not detected; a hyphen indicates that analysis was not performed for that contaminant. 
TABLE 12 Summary of Background Groundwater Concentrations for the Alluvium

\begin{tabular}{|c|c|c|c|}
\hline Parameter & $\begin{array}{l}\text { Detection } \\
\text { Frequency }\end{array}$ & $\begin{array}{l}\text { Concentration } \\
\text { Range }\end{array}$ & $\begin{array}{l}\text { Detection } \\
\text { Limit(s) }^{\mathbf{b}}\end{array}$ \\
\hline \multicolumn{4}{|c|}{ Radionuclides (pCi/L) } \\
\hline Gross alpha & $2 / 4$ & $2.3-4.3$ & 2.0 \\
\hline Gross beta & $4 i 4$ & $4.9-10.0$ & 2.0 \\
\hline Radium-226 & $4 / 4$ & $0.4-1.4$ & 0.2 \\
\hline Radium-228 & $2 / 4$ & $1.0-1.7$ & 0.9 \\
\hline Thorium-228 & $0 / 4$ & $\mathrm{ND}^{c}$ & 0.2 \\
\hline Thorium-230 & $1 / 4$ & 0.3 & 0.2 \\
\hline Thorium-232 & $0 / 4$ & ND & 0.2 \\
\hline Uranium, total & $15 / 15$ & $0.2-11$ & 0.2 \\
\hline \multicolumn{4}{|l|}{ Metals ( $\mu \mathrm{g} / \mathrm{L})$} \\
\hline Aluminum & $1 / 12$ & 93 & $35-91$ \\
\hline Antimony & $0 / 12$ & ND & $20-44$ \\
\hline Arsenic & $10 / 12$ & $2-8.2$ & 2 \\
\hline Barium & $12 / 12$ & $250-700$ & $2-16$ \\
\hline Beryllium & $0 / 12$ & ND & 1 \\
\hline Cadmium & $0 / 12$ & ND & $3-4$ \\
\hline Chromium & $0 / 12$ & ND & $6-8$ \\
\hline Cobalt & $0 / 12$ & ND & $6-10$ \\
\hline Copper & $0 / 12$ & ND & 5-10 \\
\hline Iron & $11 / 12$ & $560-13,000$ & $19-46$ \\
\hline Lead & $5 / 12$ & 3.3-77 & 2 \\
\hline Lithium & $8 / 12$ & $27-72$ & $24-100$ \\
\hline Manganese & $12 / 12$ & $250-790$ & 2 \\
\hline Mercury & $1 / 12$ & 0.04 & $0.03-0.1$ \\
\hline Molybdenum & $0 / 12$ & ND & $19-100$ \\
\hline Nickel & $0 / 12$ & ND & $11-18$ \\
\hline Selenium & $0 / 12$ & ND & 2 \\
\hline Silver & $0 / 12$ & ND & $6-10$ \\
\hline Thallium & $0 / 12$ & ND & 2 \\
\hline Zine & $6 / 12$ & $6-34$ & 6 \\
\hline \multicolumn{4}{|c|}{ Inorganic anions (mg/L) } \\
\hline Nitrate as $\mathbf{N}$ & $11 / 12$ & $0.12-0.26$ & $0.1-0.2$ \\
\hline Sulfate & $12 / 12$ & $13-60$ & $2.5-25$ \\
\hline
\end{tabular}

a Samples were collected from monitoring wells located at Darst Bottoms, upgradient of the QROU.

b Range of sample detection limits reported.

c ND indicates not detected. 


\section{TABLE 13 Comparison of Groundwater Contaminant Concentrations with Regulatory Standards}

\begin{tabular}{|c|c|c|c|c|c|c|}
\hline \multirow[b]{2}{*}{ Contaminant } & \multirow{2}{*}{$\begin{array}{c}\text { Maximum } \\
\text { Concentration } \\
\text { in Groundwater }\end{array}$} & \multicolumn{3}{|c|}{$\begin{array}{l}\text { EPA Drinking Water } \\
\text { Regulations }\end{array}$} & \multicolumn{2}{|c|}{$\begin{array}{c}\text { Missouri } \\
\text { Safe Drinking } \\
\text { Water Act }\end{array}$} \\
\hline & & MCL & MCLG & SMCL & MCL & SMCL \\
\hline \multicolumn{7}{|l|}{ Radionuclides (pCi/L) } \\
\hline Radium-226 & 4.8 & $5^{b} / 20^{c}$ & $\mathbf{0}$ & - & - & - \\
\hline Radium-228 & 5.4 & $20^{c}$ & - & - & - & - \\
\hline Thorium-228 & 1.2 & - & - & - & - & - \\
\hline Thorium-230 & 12 & - & - & - & - & - \\
\hline Thorium-232 & 4.9 & - & . & - & - & - \\
\hline Uranium, total & 6,700 & $30^{d}$ & 0 & - & - & - \\
\hline \multicolumn{7}{|l|}{ Metals (ug $\mathrm{L}$ ) } \\
\hline Aluminum & 55,000 & - & - & $5-200$ & - & - \\
\hline Antimony & 97 & $6^{\mathrm{c}}$ & $3^{c}$ & - & . & - \\
\hline Arsenic & 170 & 50 & - & - & 50 & - \\
\hline Barium & 3,100 & 2,000 & 2,000 & - & 1,000 & - \\
\hline Beryllium & 5 & 1 & 0 & - & - & - \\
\hline Cadmium & 12 & 5 & 5 & - & 10 & - \\
\hline Chromium & 76 & 100 & 100 & - & 50 & - \\
\hline Copper $^{e}$ & 78 & - & $1,300^{c}$ & 1,000 & - & 1,000 \\
\hline Iron $^{\theta}$ & 56,000 & - & - & 300 & - & 300 \\
\hline Lead & 84 & - & 0 & - & 50 & - \\
\hline Manganese & 7,200 & $200^{f}$ & - & 50 & - & 50 \\
\hline Mercury & 0.33 & 2 & 2 & - & 2 & - \\
\hline Nickel & 140 & $100^{c}$ & $100^{c}$ & - & 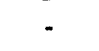 & - \\
\hline \multicolumn{7}{|c|}{ Inorganic anions $(\mathrm{mg} / \mathrm{L})$} \\
\hline Chloride & 530 & - & - & 250 & - & 250 \\
\hline Fluoride & 7 & 4 & 4 & 2 & 4 & 2 \\
\hline Nitrate as $\mathrm{N}$ & $3,400(106)^{8}$ & 10 & 10 & - & 10 & - \\
\hline Sulfate & $12,000(935)^{8}$ & $400^{c} / 500^{c}$ & $400^{c} / 500^{c}$ & 250 & - & 250 \\
\hline
\end{tabular}

Notation: MCL = maximum contaminant level; $M C L G=$ maximum contaminant level goal; SMCL = secondary maximum contaminant level.

b Concentration of radium-226 and radium-228 combined.

c Proposed value.

d The MCL is $20 \mu \mathrm{g} / \mathrm{L}$, which corresponds to $30 \mathrm{pCi} / \mathrm{L}$ for a uranium-234 to uranium-238 activity ratio of 2.7 as reported by the EPA. For an activity concentration ratio of uranium isotopes found in soil at the Weldon Spring site, the corresponding MCL is $14 \mathrm{pCi} / \mathrm{L}$.

e The EPA also lists action levels for copper and lead at 1,300 and $15 \mu \mathrm{g} /$, respectively, in 40 CFR 141.80(c).

f Listed value for regulation.

g A value in parenthesis is the next highest value below the maximum concentration; the maximum values in these cases are suspected outliers.

Sources: EPA (1992); Missouri Department of Natural Resources (1991). 
MW-1016 located adjacent to the north side of Femme Osage Slough. South of the slough, the uranium levels were considerably lower, ranging from 0.2 to $31 \mathrm{pCi} / \mathrm{L}$. This concentration range is similar to that in the alluvium in the vicinity of the quarry (i.e., 0.3 to $38 \mathrm{pCi} / \mathrm{L}$ ). The uranium concentrations measured in groundwater samples collected from monitoring wells midpoint between the slough and the St. Charles County well field ranged from 0.4 to $11 \mathrm{pCi} / \mathrm{L}$.

The higher uranium concentrations detected in the tributary alluvium east of the quarry and north and south of the slough were above the background concentrations (i.e., 0.2 to $11 \mathrm{pCi} / \mathrm{L}$ ). Uranium concentrations were within the range of background concentrations in the alluvium north of the quarry (MW-1026, MW-1035), at midpoint between the slough and the St. Charles County production wells (RMW wells), and in the St. Charles County production wells ( $\mathrm{PW}$ wells). However, the maximum uranium concentration of $6,700 \mathrm{pCi} / \mathrm{L}$ detected north of the slough in well MW-1008 greatly exceeds the EPA drinking water MCL (Table 13). The maximum uranium concentrations detected in the vicinity of the quarry and adjacent to the south side of the slough were also above the MCL.

Radium-226 and radium-228 were detected in many of the well samples from the shallow groundwater system; however, the values are low, with concentrations ranging from 0.1 to $4.8 \mathrm{pCi} / \mathrm{L}$ for radium-226 and from 1.1 to $32 \mathrm{pCi} / \mathrm{L}$ for radium-228. The detected concentration of $32 \mathrm{pCi} / \mathrm{L}$ for radium-228 is a suspected outlier; the next highest value is $5.4 \mathrm{pCi} / \mathrm{L}$, which was detected in the Kimmswick Limestone/Decorah Group along the southern rim of the quarry (MW-1030). The highsst radium-228 concentration was detected within the alluvium south of Femme Osage Slough (RMW-1).

A comparison of the detected radium-226 and radium-228 concentrations with regulatory standards and available background values shows that the combined concentrations of radium-226 and radium-228 detected in MW-1030, RMW-1, and RMW-3 are above the current MCL of $5 \mathrm{pCi} / \mathrm{L}$ (Table 13). The proposed MCL for both radium-226 and radium-228 is $20 \mathrm{pCi} / \mathrm{L}$, which is substantially higher than the groundwater concentrations that have been measured in the current monitoring well network (Table 11). The concentrations of the radium isotopes measured in the alluvium are either within the range or slightly higher than the background values.

Thorium-228, thorium-230, and thorium-232 were detected at low concentrations in the shallow groundwater system. The detected concentrations ranged from 0.15 to $1.2 \mathrm{pCi} / \mathrm{L}$, 0.1 to $12 \mathrm{pCi} / \mathrm{L}$, and 0.1 to $4.9 \mathrm{pCi} / \mathrm{L}$ for thorium-228, thorium-230, and thorium-232, respectively. In general, the groundwater containing the higher thorium concentrations were sampled from wells completed within the Kimmswick Limestone/Decorah Group along the southern rim of the quarry (MW-1002, MW-1005, and MW-1030) and from alluvial monitoring wells near Femme Osage Slough (MW-1006, MW-1007, MW-1010, MW-10107, MW-1019, and MW-1024). Groundwater samples were collected from the three wells completed within the Plattin Limestone and analyzed for thorium-228, thorium-230, and thorium-232, but none of these radionuclides were detected. The samples collected from the St. Charles County production wells did not exceed $1 \mathrm{pCi} / \mathrm{L}$ for any of the thorium isotopes. Most of the 
thorium-228, thorium-230, and thorium-232 concentrations measured within the alluvium at the site were comparable to background levels. In general, thorium concentrations in samples from wells near the slough were slightly above background levels.

The results of the preliminary assessment indicate that the alluvium and bedrock of the shallow groundwater system contain high concentrations of uranium and relatively low concentrations of radium and thorium isotopes. The highest concentrations of uranium in the bedrock were measured in the Kimmswick Limestone/Decorah Group along the quarry rim and north of Femme Osage Slough. In the alluvium, the highest concentrations were measured north of the slough. The uranium concentrations measured in groundwater samples collected from the St. Charles County monitoring wells (RMW) and production wells (PW) were within the range of the measured background values.

\subsubsection{Chemical Contaminants}

The horizontal and vertical extent of chemical contamination in groundwater was analyzed in a manner similar to that used in the assessment of radioactive contamination. Groundwater at the QROU has been sampled and analyzed for CLP metals, inorganic anions, and nitroaromatic compounds. However, except for arsenic and barium, groundwater samples have not been analyzed for metals as frequently as for radionuclides, inorganic anions, and nitroaromatic compounds. Several chemicals have been detected in the shallow groundwater system; the results of these analyses are summarized in Tables 10 and 11 . The maximum groundwatex concentration of each metal and inorganic anion detected within either the alluvium or shallow bedrock is compared in Table 13 with the EPA standards (e.g., MCLs and MCLGs) under the Safe Drinking Water Act (EPA 1992) and the Missouri standards under the Missouri Safe Drinking Water Act (Missouri Department of Natural Resources 1991). Except for copper and mercury, the maximum groundwater concentrations of all the metals and anions listed are above the federal and/or state drinking water standards. In addition to drinking water standards, the maximum detected concentrations of some of the metals and inorganic anions in the shallow alluvial aquifer are compared to background concentrations obtained for the alluvium (Kleeschulte 1993). Currently, background concentrations for the bedrock aquifer are not available for a similar comparison. The background concentrations of metals and inorganic anions in the alluvium are summarized in Table 12.

North of the quarry, a small number of groundwater samples collected from two monitoring wells completed within the Kimmswick Limestone/Decorah Group contained aluminum, antimony, barium, chromium, manganese, nickel, silver, and zinc. The maximum concentrations of aluminum, antimony, chromium, and manganese detected in the bedrock in this area (MW-1012) ace above the federal and/or state drinking water standards. The metals detected in the bedrock north of the quarry were also detected in groundwater samples collected from wells completed within the Kimmswick Limestone/Decorah Group along the quarry rim; arsenic, cadmium, copper, iron, and lead were also detected in these wells. The maximum concentrations of aluminum, antimony, cadmium, chromium, iron, lead, 
manganese, and nickel detected in several of these bedrock wells located along the quarry rim are above the federal and/or state regulatory drinking water standards (Table 13).

North of Femme Osage Slough, samples collected from wells completed within the Kimmswick Limestone/Decorah Group contained arsenic, barium, chromium, iron, lithium, manganese, mercury, silver, and zinc. The maximum concentrations of arsenic, iron, and manganese detected in these wells are above the federal and/or state regulatory drinking water standards.

Arsenic, barium, and zinc were detected in groundwater samples collected from wells completed within the upper part of the Plattin Limestone and located north of the slough. The maximum detected arsenic concentration is above the proposed MCL. Groundwater samples from the Plattin Limestone well south of Femme Osage Slough (MW-1033) contained barium, manganese, nickel, and zinc. The maximum manganese concentration is above the federal and state secondary maximum contaminant level (SMCL). The other metals detected in the upper Kimmswick Limestone/Decorah Group were not detected in the groundwater samples collected from the Plattin Limestone.

In the alluvium north of the quarry, detected concentrations of arsenic and barium are below the federal and state drinking water standards. However, the maximum arsenic concentration detected north of the quarry is above the range of background values. Groundwater samples from monitoring wells completed within the alluvium east of the quarry contained aluminum, arsenic, barium, manganese, nickel, and zinc. The maximum concentrations of all these metals are above the background values, and the maximum concentrations of aluminum, arsenic, and barium are above the federal and/or state drinking water standards. Iron was detected in the alluvium east of the quarry, with maximum concentrations above the SMCL but below background values.

In the alluvium, a limited number of groundwater samples collected from monitoring wells north of Femme Osage Slough contained aluminum, antimony, arsenic, barium, cadmium, chromium, lead, lithium, manganese, mercury, molybdenum, nickel, silver, and zinc. Except for iron, lithium, and zinc, the maximum detected concentrations were above the range of background values. The maximum concentrations of aluminum, antimony, beryllium, chromium, iron, and manganese detected in several of the wells north of the slough are above federal and/or state drinking water standards. The metals detected in the alluvial wells adjacent to the south side of the slough include arsenic, barium, beryllium, cadmium, chromium, copper, iron, lithium, manganese, mercury, molybdenum, silver, and zinc. Except for lithium, the maximum concentrations of these metals are above background values. The maximum concentrations of arsenic, beryllium, cadmium, iron, and manganese are also above the drinking water standards. Antimony, arsenic, barium, beryllium, chromium, copper, iron, lead, manganese, mercury, nickel, silver, and zinc were detected in the alluvium approximately midpoint between Femme Osage Siough and the well field. The maximum concentrations of antimony, arsenic, beryllium, chromium, iron, manganese detected in this area of the shallow groundwater system are above federal and/or state drinking water standards. 
Chloride, fluoride, nitrate, and sulfate were detected in samples from both the bedrock and the alluvium of the shallow groundwater system. The highest concentrations of chloride within the Kimmswick Limestone/Decorah Group were detected in groundwater samples from monitoring wells along the quarry rim and north of the slough. Excluding the suspected outliers, the maximum detected concentrations in the shallow bedrock were below the federal and state SMCL. Within the alluvium, the highest chloride concentrations were detected north and south of Femme Osage Slough. The maximum detected concentrations north of the slough are above the federal and state SMCL. The highest concentrations of fluoride were detected in the alluvium south of Femme Osage Slough, with maximum concentrations exceeding the state drinking water standard. Fluoride concentrations in groundwater samples from other areas of the bedrock and alluvium are below the federal and state MCL and SMCL. Omitting the suspected outliers, the highest nitrate and sulfate concentrations measured in groundwater samples from wells completed within the Kimmswick Limestone/Decorah Group were located north of the quarry, along the quarry rim, and north of Femme Osage Slough. The maximum nitrate levels measured in these areas of the shallow bedrock exceed the federal and state drinking water standards. Nitrate was also detected in the Plattin Limestone, but at concentrations below the respective drinking water standards. The maximum concentrations of nitrate and sulfate detected in the alluvium north and south of Femme Osage Slough, and approximately midpoint between the slough and the well field, are above background concentrations and exceed the federal and state drinking water standards. The concentrations of nitrate and sulfate in other areas of the alluvium are all below regulatory standards.

Nitroaromatic compounds - including 2,4-DNT, 2,6-DNT, NB, DNB, TNB, and 2,4,6-DNT - were detected in the bedrock within the Kimmswick Limestone and/or Decorah Group along the rim of the quarry and north of Femme Osage Slough. In general, the higher concentrations of nitroaromatic compounds were detected along the quarry rim. The compounds 2,4-DNT and 2,6-DNT were detected in one sample collected within the shallow bedrock north of the quarry (MW-1012). No nitroaromatics were detected within the Plattin Limestone.

Within the alluvium, nitroaromatic compounds were detected in samples collected north and south of the slough and in the area approximately midpoint between the slough and the well field. The higher concentrations of nitroaromatic compounds were measured near Femme Osage Slough. Low concentrations of nitroaromatic compounds were also detected in the well field. North of the quarry, TNB was detected in one groundwater sample from the alluvium.

In summary, several general observations can be made regarding the contaminant distribution of metals, inorganic anions, and nitroaromatic compounds at the quarry area. Compared with drinking water standards and background concentrations, elevated concentrations were measured in groundwater samples collected from both the bedrock and the alluvium of the shallow groundwater system. For most chemicals where high concentrations were detected in the bedrock aquifer (i.e., Kimmswick Limestone/Decorah Group), high 
concentrations of that same chemical were detected in the alluvium. The highest concentrations in the bedrock were measured in groundwater samples from the monitoring wells completed within the Kimmswick Limestone/Decorah Group along the southeastern and southern rims of the quarry and north of Femme Osage Slough (Table 10). The highest concentrations in the alluvium were generally collected from the monitoring wells located north of Femme Osage Slough (Table 11). For some chemicals, elevated concentrations were also detected in wells adjacent to the south side of the slough. 


\section{INITIAL SITE EVALUATION}

\subsection{CONCEPTUAL SITE MODEL}

A conceptual site model was developed to identify contaminant source areas, potential release and transport mechanisms, environmental media of concern, and potential receptors (human and ecological) and routes of exposure for the quarry area. The model was developed on the basis of current understanding of the site, including consideration of historical operations and disposal practices and available monitoring and characterization data. The model summarizes existing information regarding the site, identifies data gaps, and provides the rationale for the development of sampling plans; its purpose is to guide the remedial investigation. The model presented here will be revised to reflect the findings of the site characterization studies as additional information becomes available. The conceptual site model is depicted in Figure 14 (marked boxes represent the relevant exposure routes for each receptor). Components of this model are described in Sections 3.1.1 through 3.1.5.

\subsubsection{Contaminant Sources}

Three potential sources of contamination have been identified for the quarry area: (1) residual material in the quarry proper, (2) contaminated soil outside of the quarry proper, and (3) surface water and sediment at Femme Osage Slough. The bulk wastes, which have been addressed by previous actions and hence are outside the scope of this work plan (Chapter 1), represent one of the primary historical sources of the contamination currently present in the quarry area; hence, for the preliminary identification of radioactive and chemical contaminants, information on the contaminants in the bulk waste was considered in conjunction with the characterization and monitoring data collected for various environmental media in the quarry area (Section 3.1.2).

Similar to the bulk wastes, the quarry pond was also a major historical source of contamination, and the pond characterization data is considered in the identification of the preliminary contaminants of concern. Currently, water in the pond is being removed, treated in a water treatment plant, and then released into the Missouri River. With regard to the conceptual site model, it was hypothetically assumed that pumping operations would cease in the future and that no further action would be taken at the quarry, resulting in the pond - as well as most of the excavated quarry floor - refilling with water. Under these conditions, residual material in the walls and floor of the quarry could serve as a contaminant source. However, the future contaminant levels in the pond would be expected to be low, such that the pond would represent a contaminated medium, and not a primary contaminant source. Infiltration of pond water through the quarry bedrock would, however, continue to mobilize and transport contaminants present in the bedrock beneath the quarry to groundwater (Section 3.1.3.1). 


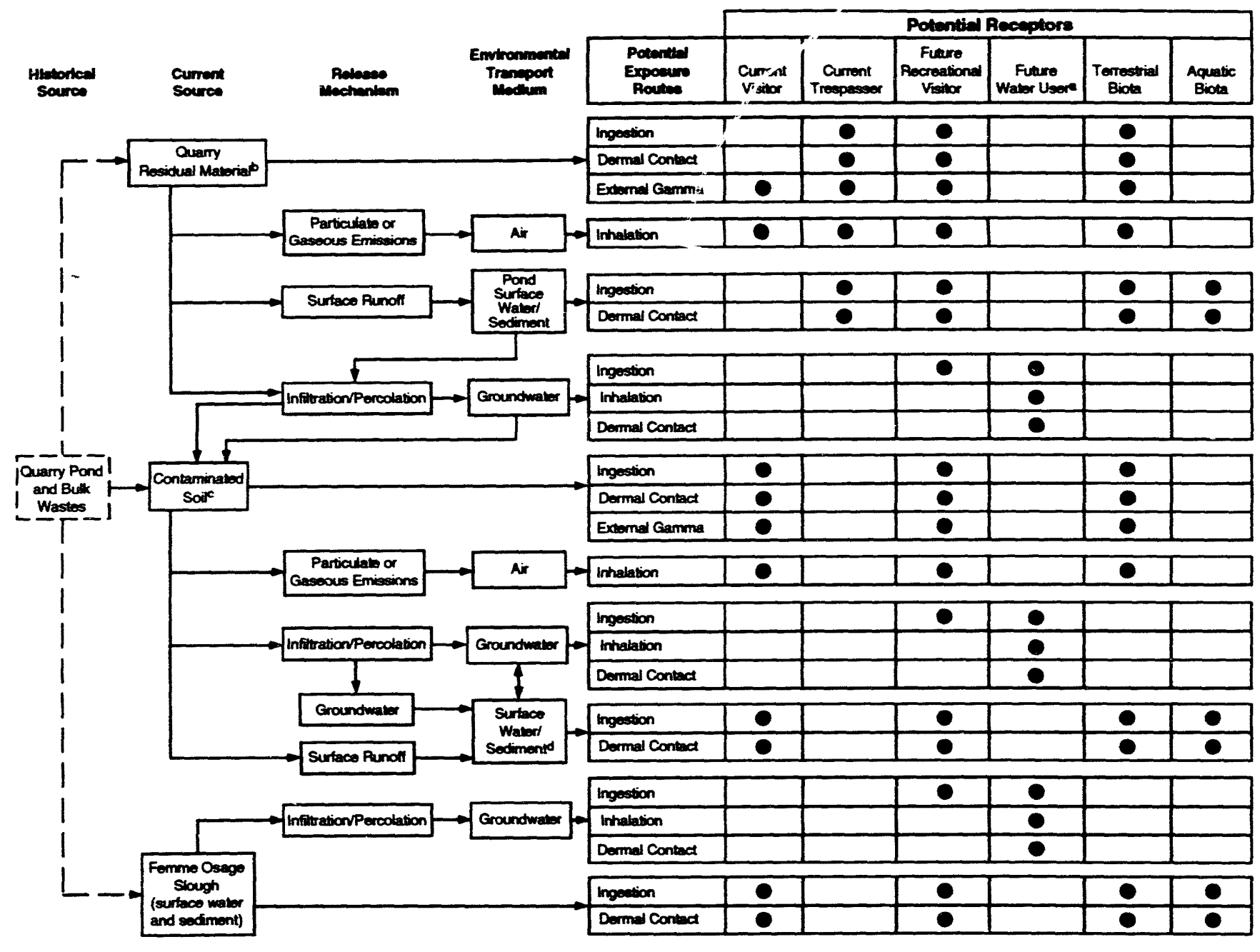

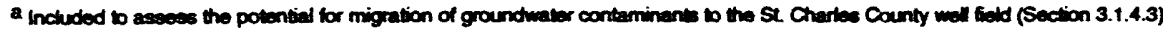

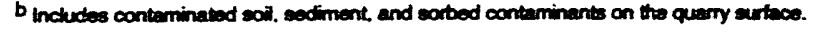

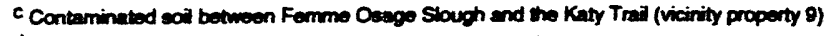

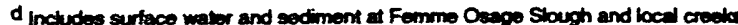

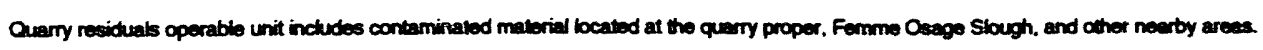

FIGURE 14 Conceptual Site Model for the Quarry Residuals Operable Unit 
The residual material remaining in the quarry following removal of the pond water and bulk waste is expected to include soil, sediment, and sorbed contaminants on exposed surfaces and within fractures of the quarry walls and floor. The nature and extent of contamination of the residual material within the quarry cannot be characterized until the bulk waste has been removed, although the radioactive and chemical contaminants are expected to be similar to those present in the pond water and bulk waste (Sections 2.4 and 3.1.2).

The second primary source is contaminated soil between the Katy Trail and Femme Osage Slough (i.e., vicinity property 9). The radiological characterization data indicate that this area is contaminated with uranium (Section 2.4.2). Chemical characterization for soil has not been completed, and additional areas of radioactively and/or chemically contaminated soil may be identified during future characterization efforts.

The third primary source is surface water and sediment in Femme Osage Slough. The results of the characterization studies presented in Sections 2.4.3 and 2.4.4 indicate that both surface water and sediment in the slough are radioactively contaminated with uranium. The results of the chemical characterization studies suggest that concentrations of some metals are elevated in the sediment. Additional studies to determine representative background concentrations for this area are required for confirmation.

The three primary source areas are likely to be linked hydrologically. Infiltration of contaminated pond water is the likely source of groundwater contamination beneath the quarry. Contaminated groundwater transported under the influence of the natural gradient to the south toward the Missouri River is the likely source of contaminated soil south of the quarry (vicinity property 9 ) and contaminated surface water and sediment at the slough. The slough and adjacent soil may also have been contaminated as a result of the disposal of contaminated water from the quarry pond into the slough during a pumping test conducted in 1960 (Richardson 1960). Although the groundwater may have contaminated the slough, the slough may also contribute to groundwater contamination at other locations, as well as to the contamination of nearby soil by infiltration, seepage, and flooding. At the present time, the linkages between the different source areas have not been thoroughly characterized; however, their qualitative influence is evident.

\subsubsection{Radioactive and Chemical Contaminants}

A preliminary list of potential radioactive and chemical contaminants for the quarry area was developed from available information on the nature of contaminants associated with the site and on contaminant persistence and mobility. Information on site contaminants includes monitoring and characterization results for the source areas and environmental media within the quarry area and characterization data for the quarry bulk waste and pond water. Also considered were the types of contaminants expected or identified at the two main locations from which the bulk waste originated: the Weldon Spring chemical plant and the Destrehan Street feed plant in downtown St. Louis (Table 5). 
Information on contaminant persistence and mobility was used to determine those contaminants most likely to have leached from the bulk waste to the underlying media. Although the pond water and bulk waste served as the historical sources of contamination in the quarry area, not all contaminants in these media would necessarily be present in the residual material or would have migrated to groundwater beneath the quarry. That is, other factors influence the fate and transport of a contaminant from the waste to the underlying media - including soil type; $\mathrm{pH}$; contaminant inventory and concentrations; contaminant solubility, mobility, and persistence; and location of contamination within the waste (i.e., near the waste surface or on the quarry floor). For example, contaminants present at low concentrations and with low persistence and/or low mobilities would not be expected to be present in the residual material (or to have migrated to groundwater), whereas those present at high concentrations and with high mobilities may have leached into the underlying residual material and to groundwater. The preliminary list of contaminants for the quarry area will be revised as additional information becomes available from the characterization efforts.

\subsubsection{Radioactive Contaminants}

For this preliminary assessment, the radioactive contaminants at the quarry area were considered to be those associated with the uranium-238, thorium-232, and uranium-235 decay series (Figures 15, 16, and 17). This is based on historical information, available monitoring and characterization data collected in various media in the quarry area (Section 2.4), and characterization results of the quarry bulk waste and pond water. The results of a source term analysis for quarry soil are presented in Table 14. This analysis indicates that some of the soil associated with the quarry contains high concentrations of thorium-230, lead-210, radium-226, and radium-228. This conclusion is consistent with the historical use of the quarry for disposal of solid waste largely associated with uranium processing activities at the chemical plant and other areas, i.e., the former St. Louis Destrehan Street plant (Table 5).

In nature, radionuclides in these three decay series are in a state of secular equilibrium in which the activities of all radionuclides within each series are equal. However, this natural state is altered during the processing of uranium and thorium ores. The rate at which equilibrium conditions are reestablished depends on the half-lives of the decay products. Radionuclides with half-lives of less than 1 year will reestablish equilibrium conditions with their longer-lived parent radionuclides within several years. Thus, because disposal activities in the quarry ceased more than 20 years ago, it can be assumed that all radionuclides with half-lives of less than 1 year have reestablished equilibrium conditions.

On this basis, each decay series can be divided into principle radionuclides from which associated shorter-lived radionuclides can be inferred. Because the majority of uranium disposed of in the quarry was natural uranium, it is reasonable to assume uranium-234 is in secular equilibrium with uranium-238. Therefore, the activities of the various radionuclides in the uranium-238 decay series can be determined from the activities of four principal radionuclides: uranium-238, thorium-230, radium-226, and lead-210. 


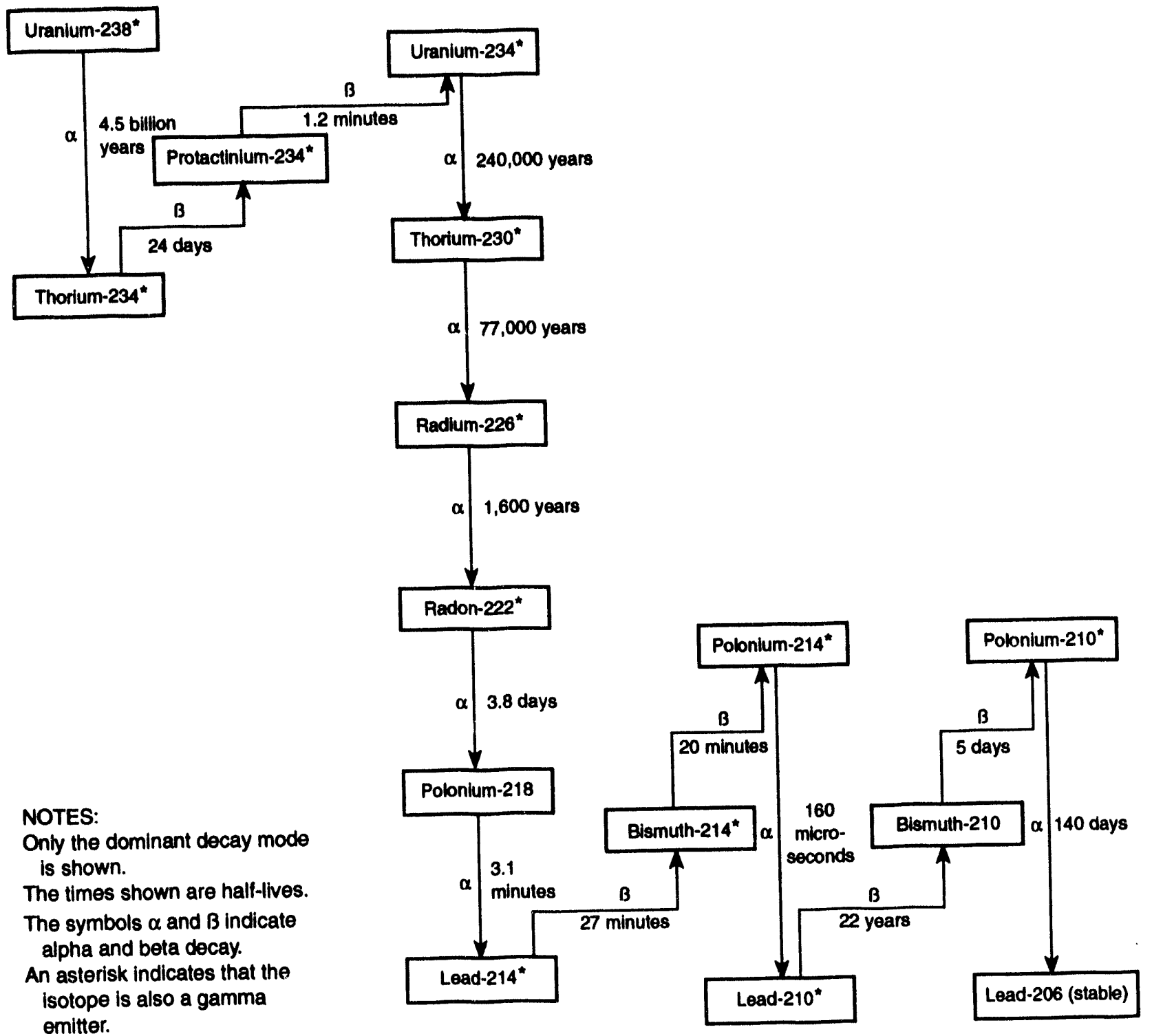

\section{FIGURE 15 Uranium-238 Radioactive Decay Series}

Accordingly, the activities of the various radionuclides in the uranium-235 decay series can be determined from measured concentrations of uranium-235, protactinium-231, and actinium-227. For the thorium-232 decay series, secular equilibrium can be assumed for all radionuclides, given the relatively short half-lives of the decay products. Thus, it is possible to infer concentrations of radionuclides in the thorium-232 series from measurements of thorium-232 and radium-228.

An isotope of radon gas - i.e., radon-222, radon-220, and radon-219 - is included in each of the three decay series. Because of the short half-lives of radon-219 and radon-220 (i.e., 3.9 and 56 seconds, respectively), the concentrations are usually low, as are the resulting health effects. Thus, only radon-222 is considered as a potential contaminant in this assessment. 


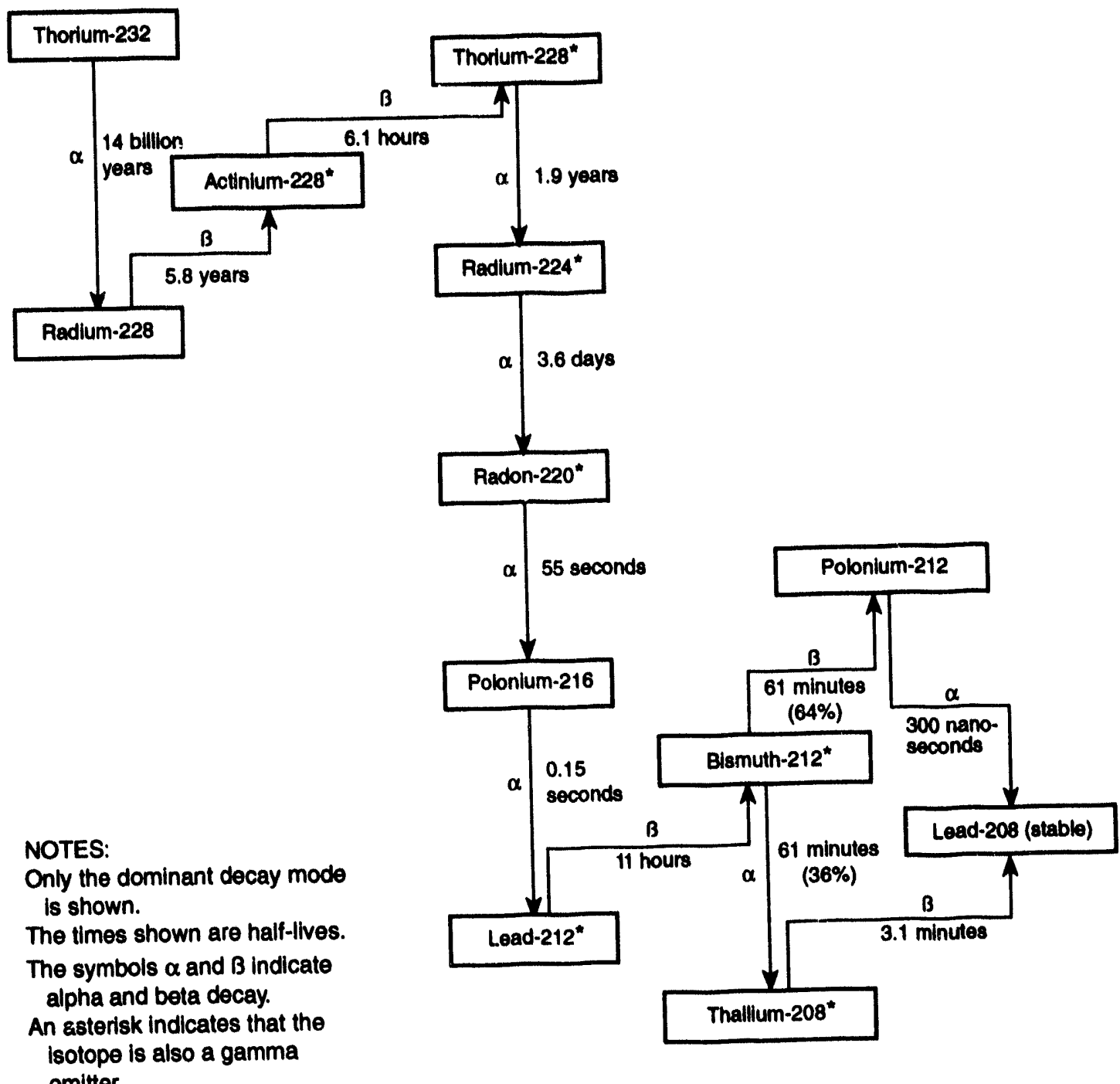
emitter.

\section{FIGURE 16 Thorium-232 Radioactive Decay Series}

The preliminary radioactive contaminants for this assessment are actinium-227, lead-210, protactinium-231, radium-226, radium-228, radon-222, thorium-230, thorium-232, uranium-235, and uranium-238. At this preliminary stage, it is not possible to drop any contaminants on the basis of characterization results because adequate sampling has not been completed and local background concentrations for many media have not been collected. For this reason, all contaminants listed above in the three decay chains have been retained as preliminary contaminants for this assessment.

\subsubsection{Chemical Contaminants}

The preliminary chemical contaminants considered for this assessment are (1) for the naturally occurring metals and inorganic anions, those elements or compounds that are 


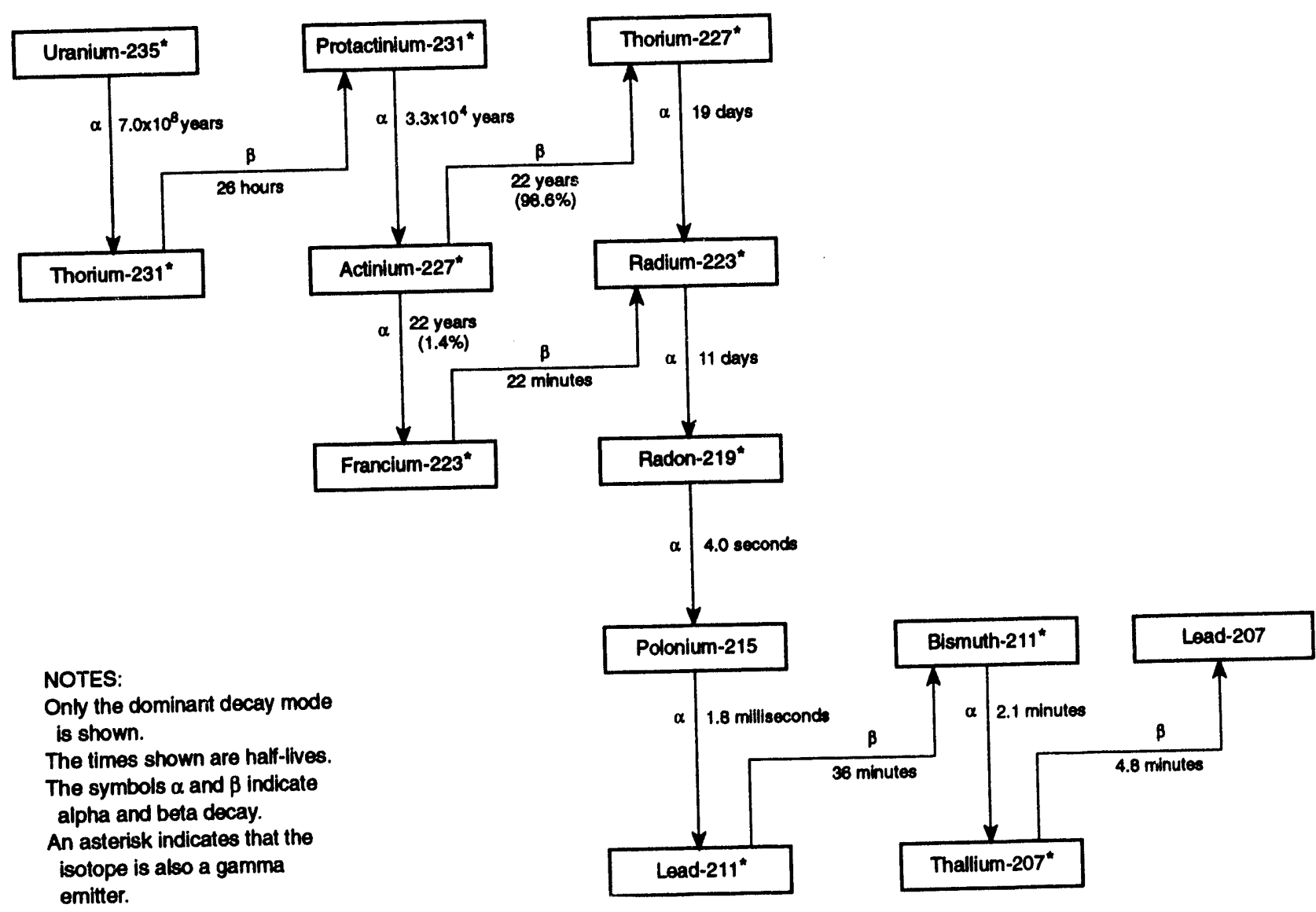

FIGURE 17 Uranium-235 (Actiniun active Decay Series

or may be present at levels above background and (2) for the anthropogenic compounds, those compounds present at levels above the limits of detection that are related to previous activities associated with the Weldon Spring site. At this early phase of the site assessment, the identification of a compound as a contaminant does not necessarily imply that a health risk or hazard is associated with exposure to that compound.

Only limited monitoring and characterization results are available to identify the chemical contaminants within the quarry area (Section 2.4). For most constituents and media, local background concentrations are not available, and characterization data are inadequate to determine representative contaminant concentrations for comparison with background. Thus, inorganic anions and CLP metals are retained as potential contaminants for all environmental media, pending the results of planned characterization studies (Section 4.3).

This approach is consistent with the historical information available for the quarry area. The inorganic chemical contaminants identified in the quarry pond and/or bulk waste include anions and metals such as arsenic, lead, wanganese, selenium, and uranium (DOE 1989; MacDoneli et al. 1989). Elevated concentrations of several metals were detected 
TABLE 14 Activity Concentration Ratios Estimated for the Major Radionuclides in Quarry Soil

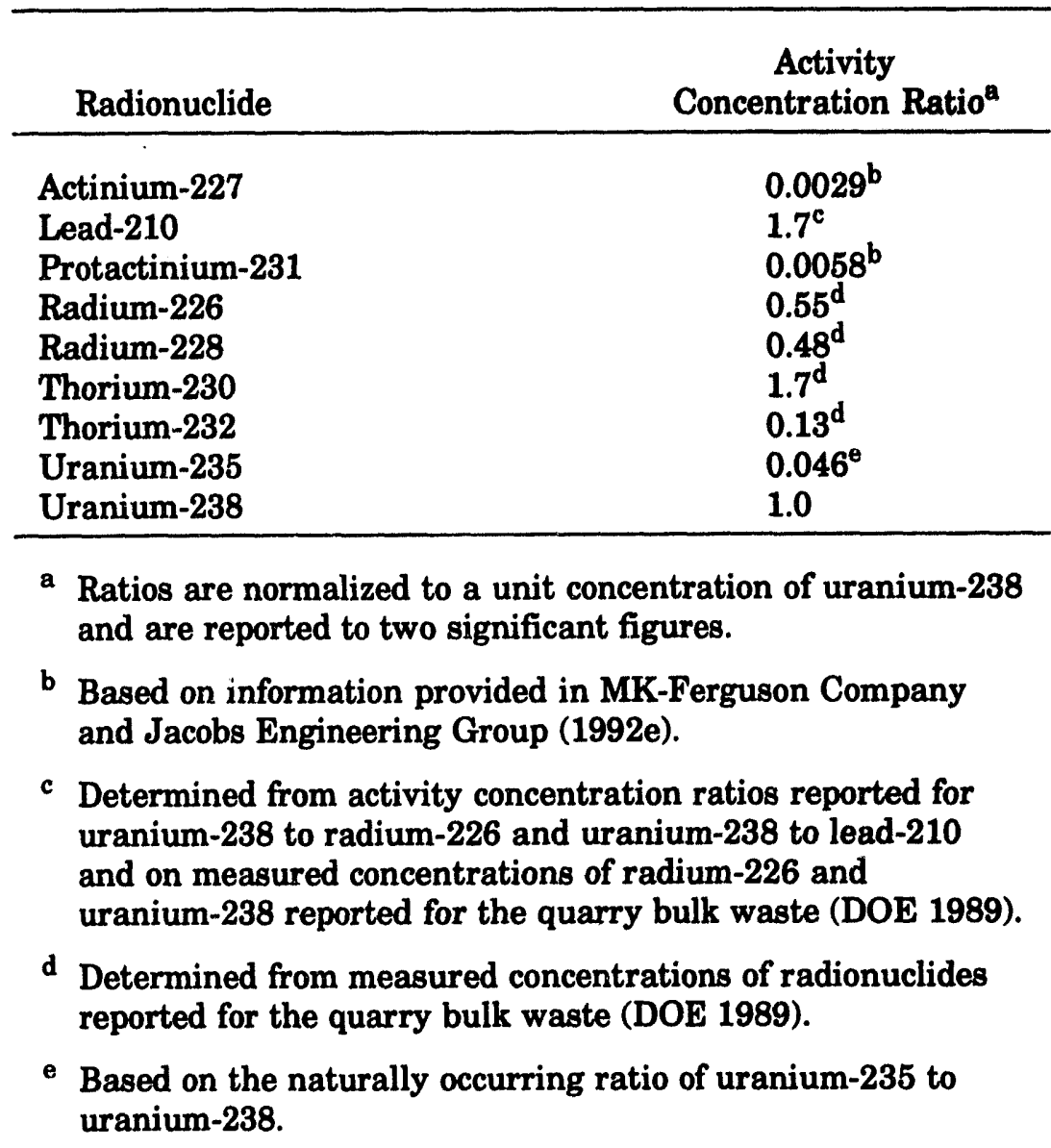

at the chemical plant (DOE 1992a), and some of these may be elevated in the quarry bulk waste and residual material. In addition, the migration of inorganic species in soil or sediment is highly influenced by the environmental conditions of the system under consideration (Bodek et al. 1988). Sufficient information is not available to assess the mobility of the inorganic constituents present in the pond and bulk waste. Thus, it is not possible to predict contaminant migration and, hence, the presence or absence of these constituents in the residual material or environmental media outside of the quarry.

The primary organic constituents identified in either the quarry bulk waste or other environmental media associated with the quarry area are polycyclic aromatic hydrocarbons (PAHs), PCBs, and nitroaromatic compounds (Section 2.4 and DOE 1989). Although low concentrations of several VOCs were also detected in some samples, these are believed to have resulted from contamination in the field and/or laboratory. The VOCs were not contaminants of concern for the chemical plant area (DOE 1992a), a finding which further supports the presumed absence of these compounds in the bulk waste. 
In contrast to the inorganic contaminants, compound-specific attenuation or distribution coefficients $\left(K_{d}\right.$ values) are available that can be applied to predict the mobility of organic compounds in a relatively broad range of soil and sediment. A discussion and listing of $K_{d}$ values for contaminants present at the chemical plant area, which includes the organic constituents at the quarry, is given in Appendix $\mathrm{E}$ of the BA for the chemical plant area (DOE 1992a). The PAHs and PCBs are well-studied compounds, and their behavior in environmental media can be predicted. The $K_{d}$ values for the individual PAHs and PCBs are relatively high, and these compounds are expected to be strongly sorbed to soil and sediment so that leaching is not considered to be a primary factor in the fate and transport of these contaminants. For this reason, it is unlikely that these compounds would be present in the quarry residual material or would have migrated to groundwater. Greater mobility is indicated for the nitroaromatic compounds, for which the $\mathbf{K}_{d}$ values are considerably lower, so leaching from the bulk waste to the residual material and into groundwater is expected. Nitroaromatic compounds have been detected in groundwater beneath the quarry (Section 2.4.7.2).

In summary, the preliminary chemical contaminants identified for the quarry area are metals, inorganic anions, and nitroaromatic compounds. The exclusion of other chemical classes at this time is preliminary, and their absence will be confirmed during RI characterization activities. In addition, the planned characterization of the bulk waste material following its excavation (DOE 1990b) will provide additional information regarding contamination in these materials. For the purpose of this work plan, identification of preliminary contaminants will guide the data quality objective process and focus the development of sampling plans (Sections 4.1 through 4.3).

\subsubsection{Potential Release and Transport Mechanisms}

The potential release and transport mechanisms for site contaminants are assessed to identify environmental media that could be impacted by releases from each of the primary sources identified at the quarry area, i.e., quarry residual material, contaminated soil, and surface water and sediment at Femme Osage Slough. Possible release and transport mechanisms identified for these source areas include the following:

- Emission of soil particulates to the atmosphere and wind dispersal;

- Radon emanation from radium-contaminated soil;

- External gamma radiation;

- Leaching of contaminants from soil and infiltration to groundwater;

- Groundwater discharge to surface water;

- Surface runoff over contaminated soil following precipitation or flooding of the Missouri River and local creeks - with transport to other soil, the slough, and other drainage areas; 
- Infiltration of surface water to groundwater; and

- Uptake by wildlife from vegetation in contaminated soil areas.

Because of the differing nature of the three source areas, all of the potential release mechanisms and receiving media listed above are not expected to play a primary role in contaminant fate and transport for each source area. The available information and factors affecting the fate and transport of contaminants from the individual areas are discussed in Sections 3.1.3.1 through 3.1.3.3.

\subsubsection{Residual Material}

Following dewatering of the pond and removal of the bulk waste, any remaining loose material would be removed from the quarry floor and walls by activities such as washing, scraping, sand blasting, and chipping as part of quarry bulk waste removal activities (DOE 1990b). These activities are expected to result in negligible contaminant release via particulate emissions because any remaining residual material would be embedded in cracks and crevices within the bedrock or strongly attached to external surfaces in the floor and walls of the quarry. Contaminants also could have entered the rock matrix by diffusion. Contaminant release via gaseous emissions would be limited to radon gas or emissions from VOCs. The production of radon gas is a potential concern if elevated levels of radium remain in the residual material. On the basis of the preliminary characterization data, release of VOCs is not expected to be a significant pathway; only low levels were detected in the bulk waste material, and, if present on surface material, these compounds would be released during washing following bulk waste removal.

The primary release mechanism associated with the quarry residual material is expected to be infiltration. Following bulk waste removal, water from precipitation or runoff not captured by a sump pump could leach contaminants from exposed surfaces and the surrounding shale and interbedded limestone matrix. Under hypothetical future conditions, in which it is assumed that pumping operations have ceased and the pond and floor of the quarry have refilled, precipitation and surface runoff would collect in the pond, which would then serve as a constant source of infiltrating water. The degree of leaching into surface runoff and pond water would be a function of the amount of material present and contaminant solubility. Assuming that the kinetics of the dissolution process can be represented by first-order reversible reactions, the rate of contaminant leaching would be proportional to the contaminant-specific $K_{d}$ values, which relate concentration in soil (solid phase) to concentration in soil water. Contaminants with high $K_{d}$ values are strongly adsorbed to soil and have the lowest rates of leaching, whereas those with low $K_{d}$ values are more easily mobilized and would be released to the underlying unconfined groundwater. Once in the groundwater, contaminants would be transported under the influence of existing hydraulic gradients. 


\subsubsection{Contaminated Soil}

Fine-grained contaminated particles can be released from surface soil to the biosphere through wind erosion and then transported in the direction of the prevailing wind. The air pathway may also transport radon gas or emissions of VOCs contained in the nearsurface soil. However, radon gas emanation and volatilization of organic compounds are not expected to be primary release mechanisms for soil because of the low concentrations of radium (the source of radon) and VOCs in contaminated soil outside of the quarry.

A second release mechanism associated with soil is surface runoff. Water from either precipitation or flooding from the Missouri River or the creeks in the area can remove soil from the surface and transport the particles to regions of lower topographic elevations. This release mechanism would be a function of ground cover and time of year.

A third release mechanism considered for contaminated soil is infiltration. In this process, water from precipitation or flooding of the Missouri River or one of the nearby creeks infiltrates the soil and leaches contaminated material. The leached material can then enter groundwater where it is transported under the influence of the existing hydraulic gradient toward the Missouri River. This transport process, however, may be complicated by the presence of Femme Osage Slough, which is near the contaminated soil. In general, the groundwater flow direction is understood; however, couplings between groundwater in the alluvium and bedrock north and south of the slough have not been well established.

\subsubsection{Surface Water and Sediment at Femme Osage Slough}

The primary release mechanisms for surface water and sediment in the slough include infiltration and discharge to groundwater. Infiltration of slough water could transport contaminants to the underlying groundwater and nearby soil. Because the slough is used for water storage during times of high stage in the Missouri River, contaminants in the slough could be transported within the slough where they would infiltrate to the groundwater or contaminate nearby soil. Characterization studies of groundwater and soil in the vicinity of the slough indicate the presence of contamination. If fluctuating groundwater levels in the vicinity of the slough are affected by elevation changes in the Missouri River, the groundwater originating at the quarry could potentially discharge to the slough during conditions in which groundwater levels are above or near the level of water in the slough; also, the groundwater could receive recharge water from the slough during conditions in which the water level is higher in the slough than in the groundwater. These conditions could lead to intermittent recontamination of both the groundwater and slough, as well as nearby soil.

South of the slough, limited data suggest that groundwater concentrations of some chemical contaminants are elevated compared with background concentrations; however, contaminant concentrations in this area are lower than those measured in groundwater wells north of the slough. This decrease in chemical concentrations may be the result of the combined clayey/silty alluvial sediments that have a high sorption capacity for contaminants 
and the flushing flows in Femme Osage Slough. The decrease in chemical contamination and the absence of radioactive contamination in the groundwater south of the slough may also be attributed to other transport mechanisms, such as groundwater flow below the alluvium and through the Plattin Limestone, vertical groundwater flow along the bedrock interface to deep parts of the alluvium, or dilution with uncontaminated groundwater from the Missouri River alluvium in the vicinity of the St. Charles County well field. Characterization has not yet been performed to determine the relative magnitudes of these separate processes.

Contaminated sediment in the slough can also be released and transported to the surrounding environment by water infiltrating from the slough and from groundwater discharge. Contaminated sediment could contribute to groundwater contamination when water in the slough infiltrates the underlying bottom sediment, thereby leaching contaminated material. This activity would occur during times when slough water is recharging the underlying groundwater. When groundwater is discharging to the slough, the bottom sediment could be leached, releasing contamination to the slough water for further transport.

\subsubsection{Potential Human Receptors and Routes of Exposure}

Exposure points are defined as points of potential contact of a receptor with a contaminated source or environmental medium. The contaminated sources and media associated with the quarry area include soil, surface water, sediment, air, and biota. Likely human activities under current and potential future land-use conditions were considered in identifying the potential human receptors at the quarry area. The routes of exposure (i.e., inhalation, ingestion, and dermal contact) identify the means by which the contaminant(s) can be taken in by a receptor; for this assessment, external gamma irradiation, inhalation, ingestion, and dermal absorption were considered as potential exposure routes.

\subsubsection{Quarry Proper}

The quarry is currently fenced and access restricted to the general public. These controls will remain in place for as long as DOE maintains ownership and determines that access restrictions are required for the protection of the general public. Hence, under current and near-term future conditions, any exposure to members of the general public would be limited to those of a current visitor (assuming supervised access) and an occasional trespasser who might gain entry to the site. Exposures incurred by these receptors would be intermittent, and the primary exposures associated with environme ical media would be expected to occur through inhalation and external gamma irradiation. In addition, the trespasser could be exposed through direct contact with the contaminated residual material, resulting in incidental ingestion of and dermal contact with soil/sediment.

Under hypothetical future conditions, it is expected that land use in the area would remain recreational, in which case the most likely receptor is a recreational user. For this assessment, it was assumed that institutional controls would be lost and that the quarry 
pond and floor would refill with water. The potential routes of exposure for the recreational visitor would include those described for the trespasser, as well as exposures associated with the pond water, that is, ingestion and dermal contact. The potential for inhalation exposure to contaminated airborne particulates is expected to be low because any remaining contaminated material would be in cracks and crevices of the quarry floor and walls, from which dispersion would be limited. Radon emanation from contaminated soil or sediment is of potential concern only if elevated levels of radium remain in the residual material.

\subsubsection{Areas Outside of the Quarry Proper}

The most likely receptor in areas outside of the quarry proper is a recreational visitor. Femme Osage Slough is used for fishing, and Katy Trail is used extensively for recreational activities such as hiking and biking; visitors could contact contaminated surface water and sediment at the slough and contaminated soil between the slough and trail. Exposures of a recreational visitor to this area would be intermittent and would depend largely on the duration of the stay and the activities pursued. Potential exposure routes for this receptor include (1) external gamma irradiation (2) direct contact with contaminated soil or sediment, resulting in incidental ingestion and dermal exposure, (3) inhalation of airborne particulates, and (4) ingestion of surface water.

Under future conditions, land use is expected to remain recreational, and the most likely receptor is the same individual identified under current conditions, that is, a recreational visitor. Because the area surrounding the quarry is part of the Weldon Spring Conservation Area, which is managed for recreational use, long-term plans for this area include more intensive recreational use, with the possible development of wetlands within the St. Charles County well field. Even with land ownership change in the long-term future, it is considered highly unlikely that the area would be used for residential or commercial purposes because of the topography of the area and the location of a portion of the land within the Missouri River floodplain. (The recent flood during the summer of 1993 crested above the hundred-year floodplain, essentially $f$ ooding the entire land area below the quarry. Although the area will continue to be used for recreational purposes, the extent of recreational use and plans for wetland development or other changes in the near term are uncertain at this time.)

Under current conditions, groundwater is not used for agricultural or recreational purposes. The water table along the alluvium is relatively shallow, and natural precipitation provides sufficient water for the agricultural crops grown in the area. Even if future land use in the area were to include continued or more extensive agricultural use, it is unlikely that groundwater would be used for irrigation. Assuming future recreational use, it is possible that wells in the alluvium could be used to provide drinking water for recreational users in the area; this potential additional pathway will be addressed in the risk assessment. The potential for groundwater transport of contaninants to the St. Charles County well field is discussed in Section 3.1.4.3. 


\subsubsection{Alluvium}

Elevated concentrations of uranium and some chemical constituents have been detected in monitoring wells completed in the alluvium north of the slough. In addition, preliminary data suggest that elevated levels of chemical constituents may be present in wells south of the slough. The primary concern associated with groundwater is the potential for migration of contaminants to the St. Charles County well field. Currently, groundwater from the well field is routinely monitored and shows no evidence of contamination.

Under current conditions, groundwater does not represent a complete exposure pathway. That is, groundwater in the alluvium in areas with elevated contaminant concentrations is not used for residential, agricultural, or other purposes. One of the objectives of the RI and associated studies will be to determine contaminant release and transport mechanisms for the groundwater pathway and the potential for contaminant migration beyond current boundaries; the potential for health effects will also be assessed. For this assessment, the hypothetical receptor is a resident within St. Charles County receiving water from the well field for residential use. In addition, the assessment compares predicted contaminant concentrations to MCLs and other relevant regulatory standards.

\subsubsection{Fish, Game, and Agricultural Crops}

In addition to the exposure pathways identified for each of the receptors at the specific source locations (Sections 3.1.4.1 through 3.1.4.3), a trespasser or recreational visitor to the quarry area or conservation area could fish in the slough or hunt game inhabiting the

contaminated area. Therefore, fish and game ingestion are also considered to be possible routes of human exposure.

The St. Charles County well field is actively farmed for crops used as livestock feed (Section 2.4.6). Samples of corn and soybeans grown in this area have been analyzed for radioactive contaminants associated with the quarry area; elevated concentrations have not been detected. These crops will continue to be monitored, although no pathway for contaminant migration into this area has been identified. In the absence of contamination, ingestion of crops by human or ecological receptors does not represent a complete exposure pathway for the quarry area.

\subsubsection{Potential Ecological Receptors and Routes of Exposure}

Because the area in the quarry vicinity is important to wildlife (with some areas being actively managed), field analyses will be performed to document the extent of wildlife use and to assess the possible impacts to biota resulting from use of potentially contaminated media. These field data will supplement those already available for the quarry area (MK-Ferguson Company and Jacobs Engineering Group 1992c, 1993a; Environmental Science and Engineering 1993). 
A number of potential exposure routes exist for ecological receptors at the quarry area. Each route is a function of the habitat type (e.g., terrestrial or aquatic), life history traits of the species (e.g., sedentary or mobile; feeding strategy), the type of contaminated media involved, characteristics of each contaminant, and the potential for synergistic or antagonistic chemical interactions (Figure 18).

Direct exposure to groundwater contamination would principally affect deep-rooted plants. Direct impacts to biota from contaminated soil would be expected to primarily affect rooted vegetation and burrowing invertebrates and vertebrates (e.g., earthworms, moles, and some salamanders). Exposure to contaminated surface water and groundwater following discharge to surface water could affect a variety of aquatic organisms, including fish, amphibians, reptiles, zooplankton, algae, rooted and nonrooted vascular plants, and macroinvertebrates. Waterfowl, shorebirds, and wading birds could also be affected, as could other terrestrial species that drink or contact contaminated water or prey upon aquatic biota. Exposure to contaminated sediment could impact burrowing aquatic organisms, rooted macrophytes, some birds (those feeding on soil invertebrates such as earthworms), benthic fish (e.g., bullheads and carp), frogs, and turtles that routinely utilize the sediment-water interface of aquatic habitats. In addition, contaminated sediment and surface water might also affect the eggs, embryos, and fry of invertebrates, fish, and amphibians. Contaminants that become sequestered in terrestrial or aquatic biota can be returned to the physical environment via decomposers, which include invertebrates, bacteria, and fungi.

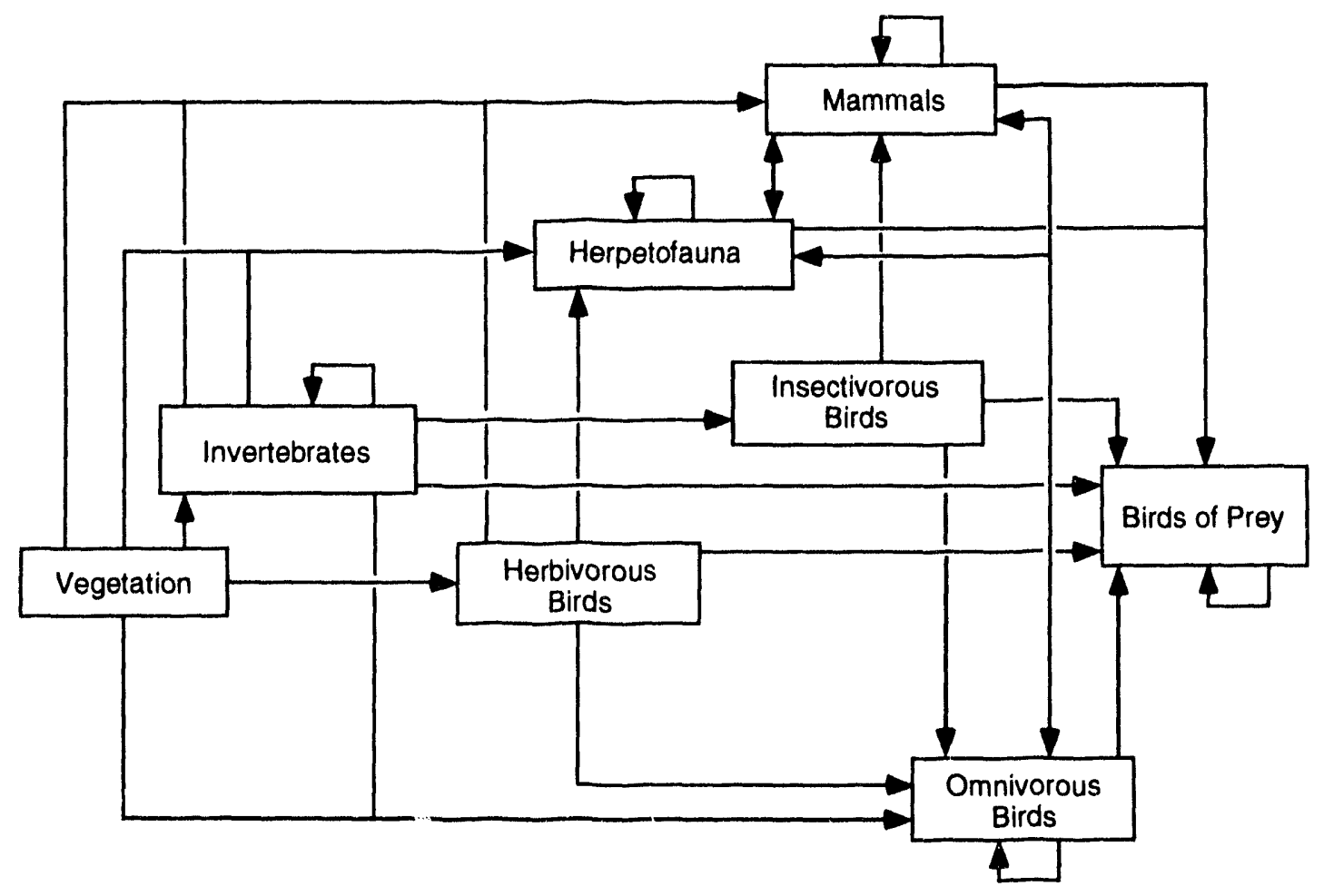

FIGURE 18 Conceptual Contaminant Food Chain Pathways for Terrestrial Biota: Vegetation to Avifauna Consumers 
Site-specific data are available for many taxa in the quarry area, including fish, owls, waterfowl, other birds, and benthic invertebrates (MK-Ferguson Company and Jacobs Engineering Group 1992c, 1993a; Environmental Science and Engineering 1993). Because potentially suitable habitats occur throughout the Busch Conservation Complex and in portions of the Weldon Spring site, and because only limited site-specific surveys for biota have been conducted to date at the contaminated (or potentially contaminated) habitats, many of the species reported from St. Charles County of the Busch Conservation Complex are potential ecological receptors for the assessment of the quarry area. Consequently, a list of appropriate receptor species for the quarry area will be defined on the basis of results obtained from field sampling and analysis activities. Nevertheless, it is possible at this time to identify some federal- and state-listed species as potential receptors. Surveys for federaland state-listed species conducted in the quarry area indicate the presence of the northern harrier (state endangered), Swainson's hawk (federal 3C, state endangered), and loggerhead shrike (federal C2, state watch list) in the St. Charles County well field (MK-Ferguson Company and Jacobs Engineering Group 1993a).

The pallid sturgeon (federal endangered) and the sicklefin and sturgeon chubs (both C2 species) have been reported from the Missouri River within $5 \mathrm{~km}(3.1 \mathrm{mi})$ downstream of the Weldon Spring site (DOE 1992b). These species are not likely to be exposed directly to contaminated sediment in the quarry and vicinity properties or to surface water that enters the river.

The bald eagle (federal endangered) is a seasonal visitor to Howell Island and might forage at or in the vicinity of the Missouri River near the quarry (MK-Ferguson Company and Jacobs Engineering Group 1993a). The peregrine falcon (federal endangered) and Cooper's hawk (state rare) are known to occur in the area and could be exposed to residual contaminants through food chain transfer. The least tern (federal endangered) is a rare summer resident in the Weldon Spring area. The bald eagle feeds primarily on fish, waterfowl, and carrion; the peregrine falcon on songbirds, shorebirds, and waterfowl; Cooper's hawk on birds and small mammals; and the least tern on small fish and insects.

To obtain the data for examining routes of exposure, biota and contaminant levels will be sampled from terrestrial and aquatic habitats in the quarry area and from background (uncontaminated) sites. These surveys will be designed to provide a thorough and quantitative description of the ecological status of the biota, contaminant levels in the physical media, estimates of contaminant biouptake, and identification of end points (Table 15). (Detailed descriptions of the sampling protocol are presented in the quarry residuals sampling plan [MK-Ferguson Company and Jacobs Engineering Group 1993b].) Terrestrial habitats to be sampled include the quarry perimeter, vicinity property 9 , agricultural fields, and portions of Little Femme Osage Creek. Background locations will be selected from the Weldon Spring Conservation Area. Aquatic surveys will be conducted in portions of Femme Osage Slough, Little Femme Osage Creek, and Femme Osage Creek. Portions of Little Femme Osage Creek and Femme Osage Creek that have not been subject to contamination from: $r$ ist activities associated with the Weldon Spring site will be selected as background 
TABLW 15 Examples of Assessment and Messurement End Points for the
Ecological Assessments in the Quarry Residuals Operable Unit

\begin{tabular}{|c|c|c|}
\hline $\begin{array}{l}\text { Target Species } \\
\text { or System }\end{array}$ & Assessment End Point & Measurement End Point \\
\hline \multicolumn{3}{|l|}{ Terrestrial } \\
\hline Upland vegetation & $\begin{array}{l}\text { Changes in species composition, } \\
\text { lower population density }\end{array}$ & $\begin{array}{l}\text { Community measures (species density, } \\
\text { richness, diversity, size-structure), } \\
\text { in-situ toxicity tests (root elongation) }\end{array}$ \\
\hline Small mammals & $\begin{array}{l}\text { Changes in species composition, } \\
\text { lower population density, } \\
\text { changes in age structure }\end{array}$ & $\begin{array}{l}\text { Community measures, chemical residues } \\
\text { in prey, histological anomalies }\end{array}$ \\
\hline Birds & $\begin{array}{l}\text { Changes in species composition, } \\
\text { lower population density }\end{array}$ & $\begin{array}{l}\text { Presence/absence, community measures, } \\
\text { residue in prey }\end{array}$ \\
\hline Soil biota & $\begin{array}{l}\text { Changes in species composition } \\
\text { and community structure }\end{array}$ & $\begin{array}{l}\text { In-situ toxicity (earthworm survival), root } \\
\text { elongation, tissue structure residues, } \\
\text { XRF screen (metals) }\end{array}$ \\
\hline $\begin{array}{l}\text { Threatened and } \\
\text { endangered species }\end{array}$ & $\begin{array}{l}\text { Increased mortality or lowered } \\
\text { reproduction in surrogates for } \\
\text { bald eagles and other species } \\
\text { listed in Table } 3\end{array}$ & $\begin{array}{l}\text { Chemical residues in prey or in surrogate } \\
\text { individuals }\end{array}$ \\
\hline
\end{tabular}

\section{Aquatic}

Vegetation Changes in species composition, lower population density, decreased productivity

Microtox ${ }^{\circledast}$ screen (sediment, water), tissue residue analyses, community measures, EPA or state water quality criteria

Animals Changes in species composition, age structure, and survival

Microtox ${ }^{\oplus}$ screen (sediment, water), residue analyses, Daphnia stress tests, community measures, survival of caged populations, EPA or state water quality criteria

Threatened and endangered species ${ }^{b}$

Increased mortality or lowered reproduction in surrogates for pallid sturgeon and other

Chemical residues in prey or surrogate individuals, EPA or state water quality criteria species listed in Table 3

a This list is preliminary and will be revised as additional data become available.

b Includes federal- and state-listed threatened and endangered species. 
locations. The Missouri River will be considered, if appropriate, on the basis of preliminary characterization efforts or on results from other aquatic areas.

\subsection{TOXICOLOGICAL AND ENVIRONMENTAL PROPERTIES OF SELECTED CONTAMINANTS}

As background information for this work plan, the toxicological effects associated with potential radiation exposure and the major toxicological effects of selected potential chemical contaminants associated with the QROU are described in Sections 3.2.1 and 3.2.2. For most of the contaminants identified, the potential is greater for chronic (long-term) than for acute (short-term) effects of humans and biota under current conditions.

\subsubsection{Radiation Toxicity}

\subsubsection{Human Health}

Radiation health effects for humans have been confirmed only at relatively high doses or at high dose rates with large populations. Hence, risk estimates are strictly applicable only to large populations because the appearance of health effects after an exposure is a chance event. For low doses, health effects are presumed to occur but can only be estimated statistically. These effects cannot be predicted with certainty for small populations (e.g., a few individuals).

Radiological health effects can be expressed as the increased likelihood of cancer induction for an exposed individual or population. However, risk estimates are uncertain for the low dose range because of the necessary extrapolation of effects from high doses and because of assumptions regarding the dose-response relationships and the underlying mechanisms of radiation carcinogenesis. In fact, studies of populations chronically exposed to low-level radiation, e.g., in regions of elevated natural background, have not shown consistent conclusive evidence of an associated higher risk of cancer induction.

Alpha, beta, and gamma radiation are released during the radioactive decay of radionuclides in the uranium-238, thorium-232, and uranium-235 decay series. Each type of radiation differs in its physical properties and in its ability to induce damage to biological tissue. Alpha particles are primarily a hazard when taken into the body (e.g., by inhalation or ingestion) because, for external exposure, they almost always lose their energy in the outer layer of dead skin cells of the body before reaching living tissue. Within the body, alpha particles result in greater cell damage than beta or gamma radiation because their energy is completely absorbed by the tissue. Beta particles are primarily an internal hazard, but, in some cases of external exposure, very energetic beta particles can penetrate to living skin cells, thus representing an external hazard as well. However, beta particles deposit less energy to tissue and therefore induce much less damage than alpha particles. Gamma radiation is primarily an external hazard because it can easily penetrate tissue and reach 
internal organs. However, only a very small fraction of the incident energy is deposited in tissue and internal organs.

Radiation exposure pathways can be separated into external and internal components. External exposure occurs when the radioactive material is outside the body, and it is primarily a concern only for gamma radiation. Intcrnal exposure occurs when the radioactive material enters the body by inhalation or ingestion. Inhaled material can be exhaled, expelled from the lungs to be either spit or swallowed and excreted, deposited in the lungs, or absorbed by the blood and relocated to other organs where it is excreted over time. Some fraction of ingested material will enter the bloodstream and be either excreted in the urine or feces or relocated to other organs and excreted over time; most insoluble ingested material is not absorbed into the blood but excreted directly via feces. For internal exposures, alpha and beta particles are the dominant concern because their energy is absorbed in cells before the particles leave the body. The biological significance of the various forms of radiation is accounted for by a quality factor that accounts for the biological effectiveness (degree of harm) of a particular radiation.

The radioactive contaminants for the quarry area (Section 3.1.2.1) are actinium-227, lead-210, protactinium-231, radium-226, radium-228, radon-220, radon-222, thorium-230, thorium-232, uranium-235, and uranium-238. These radionuclides are members of the uranium-238, thorium-232, and uranium-235 decay series (Figures 15, 16, and 17). In formation on the radiation toxicity of these radionuclides is provided in Section 4 of the BA fur the chemical plant area (DOE 1992a).

\subsubsection{Biota}

The interaction of plants with radionuclides can occur by foliar absorption of radionuclides deposited on leaf and stem surfaces or by uptake from the plant root zone in the soil. Information describing uptake and accumulation of radionuclides by plants is based mostly on short-term, relatively high-exposure laboratory experiments (Knight 1983) that may not be applicable to long-term, low-level exposure conditions such as those at the quarry area.

Although bioconcentration of uranium, radium, and thorium has been reported for fish and aquatic vegetation (Gilbert et al. 1989), no evidence exists that the radionuclides of concern biomagnify in aquatic systems (Swanson 1983; Poston and Klopfer 1988); therefore, ecological risks to species at higher trophic levels from biomagnification, e.g., of uranium, are likely to be very low. For example, Swanson (1983) noted that the radionuclide content of fish decreased from lower to higher trophic levels, and Poston and Klopfer (1988) concluded that fish occupying higher trophic levels in freshwater systems accumulated less uranium than fish occupying lower trophic levels. Although the estimated daily radiological dose to freshwater fish in surface water at or near the Weldon Spring site (Monette 1992) is well below the daily dose limit of $1 \mathrm{rad} / \mathrm{d}$ for protection of aquatic animals, data will be collected to estimate the daily dose to fish in surface waters within the QROU. Environmental monitoring results (MK-Ferguson Company and Jacobs Engineering Group 1992a) indicate 
that no adverse ecological impacts from radiotoxic effects are anticipated for aquatic biota inhabiting the surface waters near the quarry; however, continual monitoring will be conducted for the QROU remedial investigation (MK-Ferguson Company and Jacobs Engineering Group 1993b).

\subsubsection{Chemical Toxicity}

\subsubsection{Human Health}

On the basis of available historical information, aside from uranium and other radionuclides, potential contaminants at the quarry area may include other metals, inorganic anions, and some organic compounds (notably nitroaromatics). Metals identified in the various media investigated include antimony, arsenic, cadmium, chromium, lead, and thallium. Metal compounds can undergo a wide range of transformation processes, forming complexes with inorganic species or organic ligands present in the environment. These processes, collectively referred to as speciation, can occur in all environmental media. The speciation of a metal in a given environment affects its bioavailability, solubility, volatility, and sorptive properties. In addition to speciation, the fate of metals is affected by the properties of the environmental media. For example, properties affecting the mobility of a metal in water depend on the presence of other chemical species and on the $\mathrm{pH}$.

Uranium is the most widespread of the metal contaminants at the quarry area. The two main hazards associated with exposure to uranium compounds are (1) kidney damage caused by the chemical toxicity of soluble ingested uranium compounds and (2) injury caused by the ionizing radiation resulting from radioactive decay of ingested or inhaled uranium isotopes. The main effect depends on a number of factors, including the solubility of the compound, the route of exposure, and the relative composition of the isotopes. In addition to adverse effects on the kidney, the chemical toxicity of uranium can also affect the cardiovascular, endocrine, hematopoietic, and immunological systems. The extent of metal contamination at the quarry area has not yet been adequately characterized. Of the metals identified in the various media investigated to date, certain compounds of arsenic, chromium, and lead are carcinogenic and may induce teratogenic and other adverse reproductive effects.

The preliminary evaluation of historical information also indicates the potential for some levels of nitrates, nitrites, chlorides, fluorides, and sulfates to be present at the quarry area. The health hazards associated with nitrates result primarily from the bacterial conversion of ingested nitrates to nitrites. Nitrites alone can induce methemoglobinemia, a reduction in the oxygen-carrying capacity of the blood, and they can also react with other compounds, such as amines, to form $\mathrm{N}$-nitroso compounds. Although most $\mathrm{N}$-nitmso compounds are carcinogenic in experimental animals, the contribution of nitrates to a potential carcinogenic hazard for humans and the magnitude of the associated risk is unclear. Low levels of fluorides in drinking water are generally considered to have a beneficial effect on the rate and occurrence of dental caries. Ingestion of higher levels of fluorides can induce 


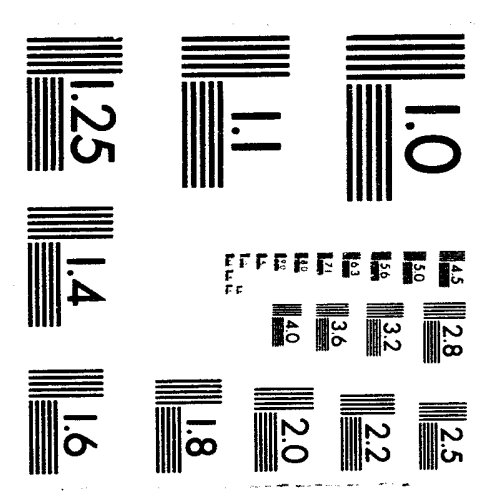



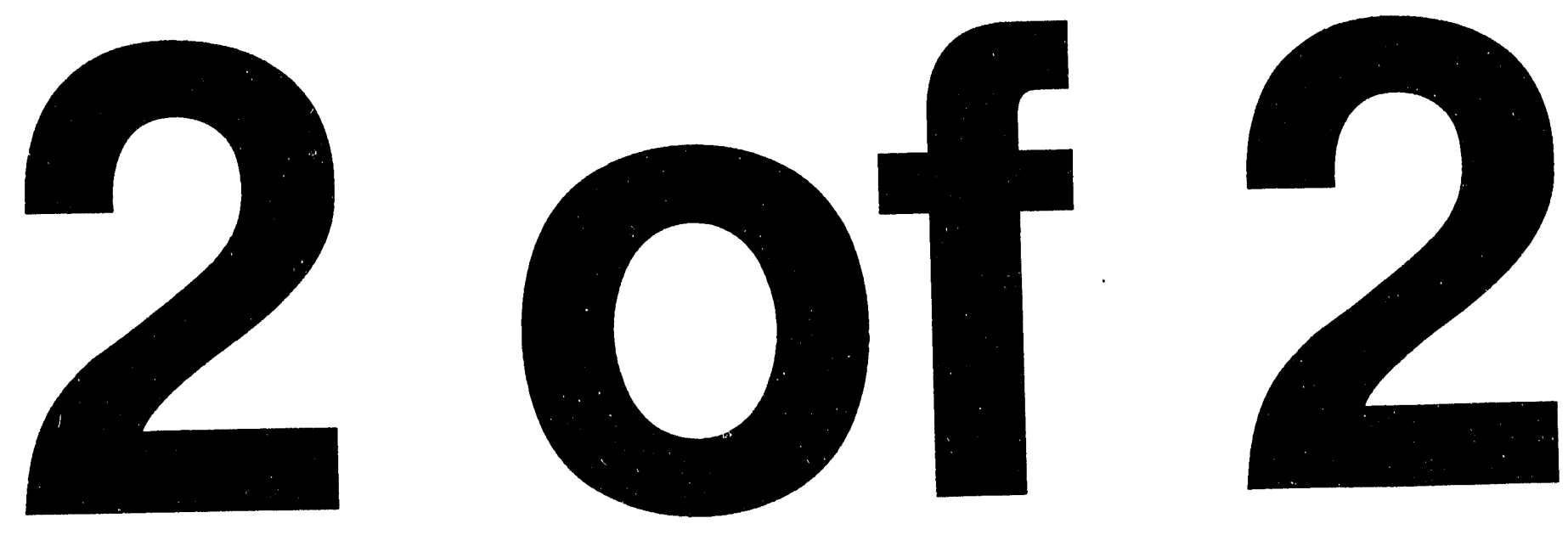
dental and skeletal fluoresces, whereas inhalation of fluorides can irritate the respiratory system.

Included in the organic compounds identified at the quarry area are DNT, TNT, and NB. Studies in experimental animals indicate hepatocellular carcinomas following the oral administration of DNT compounds. These compounds also have been shown to induce methemoglobinemia, especially in infants. Other effects include toxicity of the liver, kidney, and nervous system. Trinitrotoluene compounds induce toxicity in the hematopoietic system, the effects of which include hepatotoxicity, cataracts, and dermatitis. Acute and chronic exposures to NB compounds induce anemia and cyanosis. Studies in humans indicate that nitroaromatic compounds are absorbed following inhalation and ingestion and that these compounds are capable of penetrating the skin.

Further information on toxicity of the potential chemicals of concern at the QROU is provided in Section 4 of the BA (DOE 1992a). Metals, inorganic anions, and organic compounds that may be present at levels of potential significance will be identified during the baseline risk assessment for the QROU.

\subsubsection{Biota}

The toxicity of metals varies among biotic species and depends on physical and chemical factors such as $\mathrm{pH}$ and the presence of complexing agents or other metals. At low concentrations, metals may interfere with the metabolism of essential nutrients rather than cause direct toxic effects (Sandstead 1977). Compounds of a number of metals (e.g., cadmium, and lead) have been shown to induce cancer in laboratory animals (Sunderman 1977). However, such results generally have involved greatly elevated levels of exposure and/or methods of exposure (e.g., injection) that would not be expected under field conditions. The toxicity of metals to biota under natural conditions cannot be accurately predicted from laboratory tests because many environmental variables affect both the metal and the organism with regard to metal availability, degree of biouptake, and resulting toxicological effects.

Although the concentrations of most contaminants in the quarry area are not at levels that are individually toxic, they may still contribute to chronic toxicity to biota because of the cumulative contribution of all the contaminants. The cumulative action of contaminants can be subtractive (i.e., less than additive) but more often are additive or synergistic (i.e., greater than additive). However, this may be somewhat offset by the fact that organisms have a number of mechanisms to overcome the adverse effects of otherwise toxic metal concentrations: avoidance, exclusion, immobilization, excretion, and biochemical mechanisms (Tyler et al. 1989).

Inorganic anion contaminants that occur at the quarry include chlorides, nitrates, and nitrites, fluorides, and sulfates. Nitrites react with amines to form $\mathrm{N}$-nitroso compounds, which have been shown to be carcinogenic in experimental animals. Relatively high levels of sulfates are associated with decreased egg production in chickens and with mortality of 
some freshwater organisms. The inorganic anions are highly water soluble and, therefore, are very mobile in the environment. This mobility can result in significant leaching from soil and diffusion in soil and water.

No data are available regarding the ecological effects of nitroaromatic exposure to terrestrial wildlife and vegetation. Studies of laboratory rodents suggest that exposure to DNT and TNT via feed can cause urinary bladder carcinomas, mammary gland tumors, and kidney tumors (Ellis et al. 1979; Furedi et al. 1984). For aquatic biota, the $\mathrm{LC}_{50}$ values reported by the EPA (1986) are at least one order of magnitude higher than the concentrations reported from surface waters in the quarry area $\left(\mathrm{LC}_{50}\right.$ is the concentration lethal to $50 \%$ of the test population).

\subsection{PRELIMINARY RESPONSE OBJECTIVES AND TECHNOLOGIES}

The overall objectives of the final response action at the quarry area are to:

- Protect human health and the environment in both the short term and the long term by developing a permanent solution that addresses the radioactive and chemical contaminants in the affected media and limits related exposures;

- Implement the actions in a manner that will minimize contaminant transport to unaffected areas and attain compliance with applicable environmental requirements; and

- Release the property for unrestricted use, to the extent practicable.

The contaminated media addressed by the QROU are residual soil, sediment, and rock material in the quarry proper and soil, sediment, surface water, and groundwater in the general area of the quarry. Response objectives for the quarry response can be identified on the basis of (1) complying with available regulatory standards and guidelines and (2) limiting potential exposures and risks. Key environmental regulations that will be considered relative to compliance are identified in Section 3.6. General risk-based objectives that encompass each of these media are as follows:

- Exposures to radionuclides should be reduced to levels as far below health-based criteria as can reasonably be achieved, as limited by the natural presence of radionuclides in the given media.

- Exposures to carcinogenic chemicals should not result in a total incremental lifetime risk to an individual of more than $1 \times 10^{-6}$ to $1 \times 10^{-4}$, as limited by the natural presence of chemicals in the given media.

- Exposures to noncarcinogenic chemicals should not result in significant adverse health effects to an individual, indicated by a segregated hazard 
index above 1 , as limited by the natural presence of chemicals in the given media. (A segregated hazard index addresses noncarcinogenic health eff $\ldots$ s from exposures to multiple contaminants by considering target organ and mechanism of action of the individual contaminants, as discussed in Section 5.1.2.2 of the chemical plant BA [DOE 1992a].)

- Exposures of biota should be limited to levels that are not associated v th significant adverse ecological effects, considering available criteria and experimental and field data, as limited by the natural presence of radionuclides and chemicals in the given media.

The methodology and assumptions that have been used to estimate cancer risks, noncarcinogenic effects, and the potential for adverse ecological effects associated with the Weldon Spring project are described in detail in the BA that was recently completed for the chemical plant area (DOE 1992a). Similar discussions will be provided in the baseline risk assessment to be prepared for the QROU within the next several years to support the evaluation of cleanup objectives and appropriate response actions.

In developing responses for a contaminated site, six broad actions could be applied to each affected medium - either singly or in combination - depending on the scope of the action and the nature of the contamination problem. These six response actions are institutional controls, in-situ containment, removal, treatment, short-term storage, and disposal. However, the QROU is one component of a larger project, and the first three categories represent the key responses for this operable unit because the latter three have essentially been addressed as part of other project activities. The exception is in-situ treatment, which will be considered in evaluating possible technologies within the scope of the QROU. However, any material removed from the quarry area would be treated, stored, and disposed of in the general manner determined from previous efforts, with possible modifications (expected to be minor) as indicated by information that will be collected during the QROU effort. These previous efforts are summarized as follows.

The treatment and storage of contaminated solids generated by all project response actions - including waste generated by the two water treatment plants consiructed under earlier removal actions and upcoming activities conducted for the QROU - were recently evaluated as part of the RI/FS-EIS for the chemical plant area (DOE 1992a, 1992b, 1992c, 1992d, 1993). For disposal, the evaluation in the RI/FS-EIS addressed all site waste. The preferred alternative determined from these evaluations was to treat highly contaminated material resulting from site cleanup activities with a chemical stabilization/solidification process (using a fly ash and cement mixture) and to dispose of all radioactively and chemically contaminated waste in an engineered cell constructed at the chemical plant area. Material removed from the quarry area would be stored in a dedicated location of the chemical plant area for an estimated 5 to 7 years until the disposal facility was available. The ROD documenting the selected alternative for comprehensive treatment, storage, and disposal decisions for the project is expected in September 1993. 
For the groundwater component of the QROU, the treatment system constructed at the quarry to treat pond water under the previous removal action (Section 1.3) is expected to be appropriate for the contaminants that would be present in underlying groundwater on the basis of source similarity and available monitoring data. (This treatment system includes storage components in the form of the equalization basin and effluent ponds.) A treatability study is being developed as part of the RI/FS-EA process for the QROU, and one of the objectives of this study is to assess the applicability of the quarry system for treating contaminated groundwater beneath the area (Section 5.7). It is expected that the existing treatment plant could be easily modified if needed, e.g., to increase capacity or add any unit operation(s) indicated by new data.

In summary, the treatment, storage, and disposal of all wastes resulting from cleanup actions for the entire Weldon Spring site have been covered by previous project analyses such that any contaminated material removed from the quarry area under future response actions would be handled in the same manner described for similar material associated with those other actions. For this reason, the development of alternatives for the QROU focuses on possible institutional controls, in-situ containment and treatment, and removal activities for the final response at the quarry area. The general response actions and types of technologies that could be applied to achieve the overall objectives of the QROU action are listed in Table 16. (For an extensive presentation of all six categories of response actions and associated technologies - which was used to develop the comprehensive treatment, storage, and disposal decisions for the project - see Appendix B and Chapter 3 of the FS for the chemical plant area [DOE 1992b].)

The general objectives, response actions, and technologies that have been identified for the various contaminated media at the quarry at this stage of the evaluation process provide the building blocks for developing conceptual alternatives for the quarry area. Preliminary alternatives are identified for the QROU in Section 3.4. Performance reliability and the expected permanence of the various response technologies as applied to conditions at the quarry area are important factors that will be evaluated as part of the ongoing RI/FS-EA process for this action. The three basic criteria that will be applied to evaluate the appropriateness of the technologies and assembled alternatives are effectiveness, implementability, and cost, and an evaluation against these criteria will be presented in the FS for the QROU to be prepared within the next several years.

\subsection{CONCEPTUAL REMEDIAL ACTION ALTERNATIVES}

The EPA has established a general framework for developing remedial action alternatives that is appropriate to the specific conditions at an NPL site (EPA 1988, 1990a). The scope, characteristics, and complexity of an individual operable unit or site constitute the case-specific framework from which to develop a preliminary list of alternatives that would be protective of human health and the environment. This protection can be achieved by eliminating, reducing, and/or controlling risks posed by each exposure pathway associated with the operable unit or site. Alternatives are assembled by combining general responses 
TABLE 16 General Response Actions and 'Technologies

\begin{tabular}{|c|c|c|}
\hline $\begin{array}{l}\text { General Response Action/ } \\
\text { Technology Type }\end{array}$ & Affected Medium & Comment \\
\hline \multicolumn{3}{|l|}{ No action } \\
\hline Not applicable & All & $\begin{array}{l}\text { Provides a baseline for comparison with action } \\
\text { alternatives. }\end{array}$ \\
\hline \multicolumn{3}{|l|}{ Institutional control } \\
\hline Access restrictions & All & $\begin{array}{l}\text { Could limit entry to contaminated areas and } \\
\text { related exposures. }\end{array}$ \\
\hline $\begin{array}{l}\text { Ownership and use or } \\
\text { deed restrictions }\end{array}$ & All & $\begin{array}{l}\text { Could minimize exposures to contaminants by } \\
\text { limiting use of contaminated areas. }\end{array}$ \\
\hline Monitoring & All & $\begin{array}{l}\text { Could provide data useful for assessing and } \\
\text { minimizing exposures. }\end{array}$ \\
\hline \multicolumn{3}{|l|}{ In-situ containment } \\
\hline Surface controls/diversions & $\begin{array}{l}\text { Soil, sediment, } \\
\text { surface water }\end{array}$ & $\begin{array}{l}\text { Could limit contaminant mobility and resultant } \\
\text { exposures by directing surface runoff around } \\
\text { contaminated areas. }\end{array}$ \\
\hline Caps and covers & $\begin{array}{l}\text { Soil, sediment, } \\
\text { rock }\end{array}$ & $\begin{array}{l}\text { Could reduce exposures by limiting airborne } \\
\text { emissions, attenuating gamma radiation, and } \\
\text { reducing precipitation-enhanced percolation and } \\
\text { leaching. }\end{array}$ \\
\hline Lateral barriers & $\begin{array}{l}\text { Soil, sediment, } \\
\text { surface water, } \\
\text { groundwater }\end{array}$ & $\begin{array}{l}\text { Could limit lateral migration of contaminants } \\
\text { and the potential for subsequent exposures. }\end{array}$ \\
\hline Bottom seals & $\begin{array}{l}\text { Soil, sediment, } \\
\text { surface water, } \\
\text { groundwater }\end{array}$ & $\begin{array}{l}\text { Could limit vertical migration of contaminants } \\
\text { and the potential for subsequent exposures. }\end{array}$ \\
\hline \multicolumn{3}{|l|}{ Removal } \\
\hline Excavation & $\begin{array}{l}\text { Soil, sediment, } \\
\text { rock }\end{array}$ & $\begin{array}{l}\text { Could remove the remaining sources of contami- } \\
\text { nation from the quarry area, thereby reducing } \\
\text { related exposures. }\end{array}$ \\
\hline Dredging & Sediment & $\begin{array}{l}\text { Could remove sediment from affected surface } \\
\text { water bodies (e.g., the slough), thereby reducing } \\
\text { related exposures. }\end{array}$ \\
\hline Interception and pumping & $\begin{array}{l}\text { Surface water, } \\
\text { groundwater }\end{array}$ & $\begin{array}{l}\text { Could remove water from beneath the quarry } \\
\text { area, thereby reducing related exposures; could } \\
\text { provide the means for a contingency response, if } \\
\text { needed. }\end{array}$ \\
\hline
\end{tabular}


TABLE 16 (Cont.)

\begin{tabular}{|c|c|c|}
\hline $\begin{array}{l}\text { General Response Action/ } \\
\text { Technology Type }\end{array}$ & Affected Medium & Comment \\
\hline \multicolumn{3}{|l|}{ In-situ treatment } \\
\hline $\begin{array}{l}\text { Physical extraction/ } \\
\text { flushing }\end{array}$ & $\begin{array}{l}\text { Soil, sediment, } \\
\text { rock }\end{array}$ & $\begin{array}{l}\text { Could separate certain contaminants from these } \\
\text { media for subsequent removal, thereby reducing } \\
\text { related exposures; migration control is an issue. }\end{array}$ \\
\hline $\begin{array}{l}\text { Physical extraction/ } \\
\text { evaporation }\end{array}$ & Surface water & $\begin{array}{l}\text { Could separate solid contaminants from surface } \\
\text { water for subsequent removal, thereby reducing } \\
\text { related exposures; migration control is an issue. }\end{array}$ \\
\hline $\begin{array}{l}\text { Physical extraction/ } \\
\text { stripping }\end{array}$ & Groundwater & $\begin{array}{l}\text { Could remove certain chemicals (e.g., VOCs) } \\
\text { from groundwater if present, thereby reducing } \\
\text { related exposures. }\end{array}$ \\
\hline Dewatering/drying & Soil, sediment & $\begin{array}{l}\text { Could reduce the mobility of contaminants and } \\
\text { related exposures. }\end{array}$ \\
\hline Vitrification & Soil, sediment & $\begin{array}{l}\text { Could bind contaminants in a solid matrix and } \\
\text { reduce the toxicity, mobility, and volume of } \\
\text { contamination, thereby reducing related } \\
\text { exposures. }\end{array}$ \\
\hline $\begin{array}{l}\text { Chemical extraction/ } \\
\text { flushing }\end{array}$ & $\begin{array}{l}\text { Soil, sediment, } \\
\text { rock }\end{array}$ & $\begin{array}{l}\text { Could reduce the mobility of contamination and } \\
\text { the toxicity of certain chemicals (e.g., organic } \\
\text { compounds) by altering their forms, thereby } \\
\text { reducing related exposures; migration control is } \\
\text { an issue. }\end{array}$ \\
\hline $\begin{array}{l}\text { Chemical s.idition/ } \\
\text { detoxification }\end{array}$ & $\begin{array}{l}\text { Soil, sediment, } \\
\text { surface water }\end{array}$ & $\begin{array}{l}\text { Could reduce the mobility of contamination and } \\
\text { the toxicity of certain chemicals (e.g., organic } \\
\text { compounds) by altering their forms, thereby } \\
\text { reducing related exposures; migration control is } \\
\text { an issue. }\end{array}$ \\
\hline $\begin{array}{l}\text { Chemical injection, contact } \\
\text { reaction }\end{array}$ & Groundwater & $\begin{array}{l}\text { Could reduce the mobility of contamination and } \\
\text { the toxicity of certain chemicals (e.g., organic } \\
\text { compounds) by altering their forms, thereby } \\
\text { reducing related exposures; migration control is } \\
\text { an issue. }\end{array}$ \\
\hline $\begin{array}{l}\text { Chemical stabilization/ } \\
\text { solidification }\end{array}$ & Soil, sediment & $\begin{array}{l}\text { Could bind contaminants in a solid matrix to } \\
\text { limit mobility, thereby reducing related } \\
\text { exposures. }\end{array}$ \\
\hline $\begin{array}{l}\text { Biodegradation, bio- } \\
\text { reclamation }\end{array}$ & $\begin{array}{l}\text { Soil, sediment, } \\
\text { surface water, } \\
\text { groundwater }\end{array}$ & $\begin{array}{l}\text { Could reduce the mobility of contamination and } \\
\text { the toxicity of certain chemicals (e.g., organic } \\
\text { compounds) by altering their forms, thereby } \\
\text { reducing related exposures; migration control is } \\
\text { an issue. }\end{array}$ \\
\hline
\end{tabular}


and identifying basic technologies that could be appropriate for each contaminated medium to be addressed by the action.

Two major categories of response are typically considered in developing these alternatives for a contaminated site:

- Containment - involving little or no treatment but protective of human health and the environment by preventing or controlling exposures to contaminants through engineering measures and by using institutional controls as necessary ensure the continued effectiveness of a response; and

- Treatment - ranging from alternatives that use treatment as the primary element of the response to address the principal threat(s) posed by a site (this may not involve the highest degree of treatment or the treatment of all waste) to alternatives that use treatment to reduce the toxicity, mobility, or volume of contaminated material to the maximum extent feasible, minimizing the need for long-term management.

In addition, to develop response actions for groundwater, a limited number of alternatives are considered that could attain site-specific remediation levels within different restoration time periods by using one or more different technologies. A no-action alternative - or no further action where a remedial action is preceded by interim response actions at a site is also included to provide a baseline for comparison with other alternatives.

As stated in Section 121(b) of CERCLA, as amended, the alternatives most preferred by the EPA for NPL sites are those that represent permanent and cost-effective solutions for protecting human health and the environment; those that permanently and significantly reduce the toxicity, mobility, or volume of contaminated material; and those that apply alternative treatment or resource recovery technologies to the extent possible. Least preferred are those alternatives involving the transport and disposal of waste off-site without treatment.

For the QROU, the no-action alternative assumes that response actions for which decisions have already been finalized will have been completed. That is, the water will have been removed and treated and the bulk waste will have been excavated and placed in storage at the chemical plant area of the Weldon Spring site. Because the QROU component of the Weldon Spring project represents a focused action for one operable unit of a multiunit site, the treatment, storage, and disposal components following removal that are typically incorporated into site remediation alternatives have already been addressed as part of other project activities. Therefore, the preliminary list of remedial action alternatives and associated technologies developed for the quarry area does not reconsider those previous determinations.

The conceptual alternatives identified in this work plan represent a general classification of possible activities for the quarry response, and these alternatives are based on the current understanding of the important exposure routes and receptors in the area. 
The alternatives will be refined as the RI/FS-EA process proceeds. The purpose of identifying potential alternatives at this early stage of the process is to help ensure that appropriate data are collected to support the subsequent analyses of candidate technologies and alternatives. The potential alternatives are as follows:

- Alternative 1 - No action (i.e., no further action beyond the interim actions that will already have been conducted at the quarry).

- Alternative 2 - Institutional controls would be continued for surface water and sediment in Femme Osage Slough and for groundwater and soil in the quarry area by monitoring to assess the effectiveness of previous source control actions at the quarry (i.e., removal of the pond water and bulk waste).

- Alternative 3 - The quarry proper would be contained in place by capping with backfill material such as soil and gravel; vicinity property soil would be contained in place by capping with clean soil; and institutional controls would be continued as for Alternative 2 .

- Alternative 4 - Same as Alternative 3, except vicinity property soil would be treated in place by chemical stabilization/solidification.

- Alternative 5 - Same as Alternative 3, except vicinity property soil would be treated in place by dewatering and vitrification.

- Alternative 6 - Same as Alternative 3, except vicinity property soil would be removed (excavated) for subsequent treatment/disposal as determined from the ROD for the project's recent RI/FS-EIS for the chemical plant area.

- Alternative 7 - Residual material would be removed (excavated) from the quarry proper, and soil and sediment would be removed from vicinity properties (including Femme Osage Slough); this material would be disposed of at the chemical plant area in the facility being constructed pursuant to the recent disposal decision for the project.

Under each of these alternatives, the feasibility of removing groundwater for treatment will be evaluated under a treatability study that is expected to be conducted within the next 2 years. Technologies such as pumping wells and interceptor trenches are being considered for this study effort. In addition, characterization data that will be collected as part of the remedial investigation for the quarry area is expected to provide information on the nature and extent of contamination that will be used to assess the feasibility of in-situ treatment. After the additional data have been collected and the treatability study has been completed, the results will be used to develop an appropriate range of alternatives for the groundwater response (e.g., by modifying the groundwater component of Alternatives 4 and 5). 
Similarly, the results of upcoming characterization efforts for the surface water components of this operable unit (e.g., water in the Femme Osage Slough and two nearby creeks) might result in modifications to this preliminary list of alternatives. However, current information does not indicate a health or environmental threat from this surface water, which is indirectly affected by contaminants in other media that are being addressed by this action (e.g., soil and sediment). For this reason, monitoring following source control actions is the current conceptual response for this medium.

Interim response actions may also be taken as part of the QROU, as indicated in Section 1.3. The need for these actions will be reviewed as data continue to be collected for the quarry area (given that washout from the recent flooding has probably changed conditions in that area). The interim actions being considered include excavating localized pockets of contaminated sediment and soil that may be found in vicinity property areas, including Femme Osage Slough and the area north of the slough. This material would be transported to the chemical plant area for short-term storage until the disposal facility is operational, in the same manner as is currently being conducted for the quarry bulk waste under a previous interim action (see Section 1.3).

In conclusion, this preliminary list of alternatives will continue to be developed as additional data are collected to support the evaluation of a final response for the quarry area. A refined list will be presented and analyzed in the FS that will be prepared for the QROU.

\subsection{DATA GAPS}

The current level of understanding of the conceptual site model in the quarry area is a result of previous studies (listed in Table 4) and past environmental monitoring plans (e.g., MK-Ferguson Company and Jacobs Engineering Group 1992a) that were performed to address some of the issues associated with water resource development in the alluvium and the storage and removal of waste in the quarry. The impacts of waste storage in the quarry and contaminant migration have provided the rationale for the data that have been collected at the site as part of an environmental monitoring program. Data used to develop the conceptual model are in most cases likely to be relatively accurate because standard methods were used in the data collection and analysis. However, some of these studies were not designed in accordance with CERCLA guidance and did not identify or quantify potential adverse ecological effects; consequently, the quality of the historical data varies and the validity of some of these data and the associated conclusions cannot be adequacely verified and documented to meet the CERCLA documentation process. In addition, the ecological studies at the Weldon Spring site preceded EPA guidance on ecological risk assessments (EPA 1989d).

In general, the data gaps include characterization of (1) the nature, extent, and magnitude of chemical and radioactive contamination; (2) hydrogeological conditions - to evaluate factors affecting the distribution, fate, and transport of the contaminants; and (3) ecological conditions - to determine whether adverse ecological effects have occurred and what the potential is for future adverse impacts. 


\subsubsection{Radioactive and Chemical Contaminants}

Although some information is available regarding contaminant conditions at the quarry area, additional data are needed to adequately characterize the quarry and surrounding vicinity. The data gaps include spatial and temporal information on the nature and extent of contamination in environmental media (i.e., soil, sediment, surface water, and groundwater). Specifically, these data gaps include the following:

- Soil in the area upland of the quarry and soil located north of the slough and south of Katy Trail (vicinity property 9 ) should be sampled for radiological and chemical parameters to provide a complete inventory of the spatial and vertical distribution of parameters within these different areas.

- Sediment in Femme Osage Slough, Little Femme Osage Creek, and Femme Osage Creek should be sampled for radiological and chemical parameters to provide an inventory of the distribution of parameters within these sediments.

- Surface water in Femme Osage Slough, Little Femme Osage Creek, and Femme Osage Creek should be sampled for radiological and chemical parameters to evaluate fully the water quality.

- The shallow groundwater within the bedrock and the alluvium should be sampled for radiological and chemical parameters to provide a complete inventory of the spatial distribution of the potential contaminants within the groundwater. The chemistry of the groundwater should also be defined vertically to delineate, for example, the extent of contamination within the shallow groundwater system.

- Although some samples were collected from the alluvium to determine background concentrations of contaminants, a comprehensive investigation is needed to define background concentrations of radioactive and chemical contaminants within the soil and surface water and within the shallow groundwater system to help delineate the contaminants of concern.

\subsubsection{Hydrogeologic Characterization}

In general, the groundwater flow characteristics in the study area are understood at a basic level. To further define potential migration pathways for contaminant migration from the quarry, hydrogeologic data gaps have been identified in three general areas: the aquifer characterization parameters of the bedrock and the alluvium, the hydrogeologic connection 
between the bedrock and alluvium, and the hydrogeologic connection between the groundwater and surface water features. These data gaps are as follows:

- Information is needed to characterize the contact and to define the flow paths and gradient(s) between the shallow bedrock - which includes the Kimmswick Limestone, Decorah Group, and Plattin Limestone - and the alluvium.

- Data should be collected to characterize groundwater flow and contaminant transport within the bedrock and alluvium of the shallow groundwater system, specifically in the areas of the quarry and Femme Osage Slough. Characterization parameters include strata thickness, hydraulic conductivity, effective porosity, storativity (specific yield), anisotropy, heterogeneity, and dispersion coefficients. Data should also be collected on the fractures and solution features to assess contaminant migration pathways and to model flow and transport in the bedrock units. These data include fracture orientation, spacing, aperture, vertical and horizontal length, and degree of weathering. In addition, the distribution of vertical fractures with respect to depth should be characterized.

- Routine environmental monitoring data are available to evaluate seasonal influences on groundwater levels. Limited data are also available on the elevation of the surface water in Femme Osage Slough and the Missouri River. However, the hydrologic connection between the groundwater, Femme Osage Slough, and the Missouri River needs to be defined to evaluate the potential routes of contaminant migration from the quarry.

- In addition to the hydrogeologic information, data should be collected to address the attenuation characteristics of the bedrock and the alluvium. Specifically, the data gaps include estimates of distribution coefficients of the aquifer materials for the contaminants of interest that will be defined from the radiological and chemical sampling.

- Precipitation, evaporation, transpiration, runoff, and soil permeability data should be collected to estimate the effective recharge or the total amount of water that recharges the shallow groundwater system.

Information needed to characterize flow and contaminant transport in the unsaturated zone includes:

- Capillary moisture retention characteristics, water content, and anisotropy; and

- Effective porosity, bulk density, mineralogy, grain-size distributions, and dispersion coefficients. 


\subsubsection{Ecological Resources}

General information needed to establish a relationship between environmental contaminants and observed ecological effects has been developed and specified in EPA (1989d) guidance. In addition to defining the nature, extent, and magnitude of contamination, ecological surveys are necessary to establish whether adverse ecological effects have occurred, and toxicity tests are necessary to identify potential ecological impacts and to establish a link between any realized adverse ecological effects and the toxicity of the hazardous wastes and contaminants. These data are necessary to eliminate other potential causes of observed ecological effects, unrelated to the effects from contaminants at the site.

The available literature regarding environmental concentrations of uranium, thorium, and radium thai may produce adverse effects in natural populations of plants, fish, and wildlife is concerned primarily with uptake rather than effect (Section 3.2.1.2). Literature concerning the movement, concentration, and effects of radionuclides on biota are sparse. Thus, it is not possible to fully assess the adverse risks to site biota from the radioactive contaminants that may be present in the quarry residuals. Maximum concentrations of many of the contaminants present at the site and at some of the vicinity properties are known to cause a range of adverse effects at sublethal concentrations. Additional data on the local biota are needed to fully identify the potential for adverse effects resulting from quarry residual contaminants.

Landsat thematic mapper imagery will also be used to classify habitat types and to aid in the detection of stressed vegetation (both upland and wetland). Detectable stress alone will not be a basis for concluding that adverse impacts are related to contaminant exposure. This imagery, combined with quantitative data (and derivative indices such as diversity) and characterization of contaminant levels in media, will provide much of the evidence necessary to determine if natural adverse impacts exist or potentially exist. Simple soil analyses (e.g., texture and $\mathrm{pH}$ ) and soil data collected for other components of this RI effort will be used to determine if differences in natural soil characteristics could be related to differences in vegetation types and vigor. Overall information needed to perform an ecological risk assessment for the QROU include that summarized in Table 17. Some specific ecological data gaps include the following:

- An inventory of terrestrial and wetland plants to quantify each species;

- Bioaccumulation of contaminants in different plant species;

- An inventory of the aquatic biota in Femme Osage Slough, Femme Osage Creek, and Little Femme Osage Creek to quantify the different species of benthic invertebrates, herpetofauna, and fish;

- Bioaccumulation of contaminants in aquatic species, such as fish and waterfowl tissue from Femme Osage Slough, Femme Osage Creek, and Little Femme Osage Creek; 
TABLE 17 Examples of Possible Tests and Surveys for the Ecological Assessment of the Quarry Residuals Operable Unit ${ }^{\mathrm{a}}$

\begin{tabular}{|c|c|c|c|c|}
\hline Test & $\begin{array}{c}\text { Protective } \\
\text { of } \\
\text { Uplands }\end{array}$ & $\begin{array}{c}\text { Protective } \\
\text { of } \\
\text { Aquatic } \\
\text { Systems }\end{array}$ & $\begin{array}{c}\text { Protective } \\
\text { of } \\
\text { Threatened and } \\
\text { Endangered } \\
\text { Species }\end{array}$ & $\begin{array}{l}\text { Bald Eagle } \\
\text { Pathway }\end{array}$ \\
\hline Upland vegetation surveys & $\mathbf{x}$ & - & $\mathbf{x}$ & - \\
\hline Herpetofauna & $\mathbf{x}$ & $\mathbf{x}$ & $\mathbf{x}$ & - \\
\hline Aquatic vegetation surveys & - & $\mathbf{x}$ & $\mathbf{x}$ & $\mathbf{x}$ \\
\hline Aquatic animal surveys & - & $\mathbf{x}$ & $\mathbf{X}$ & $\mathbf{x}$ \\
\hline $\begin{array}{l}\text { Threatened and endangered species } \\
\text { surveys }\end{array}$ & $\mathbf{x}$ & $\mathbf{x}$ & $\mathbf{x}$ & - \\
\hline Microtox ${ }^{\oplus}$ testing of surface water & - & $\mathbf{x}$ & $\mathbf{x}$ & $\mathbf{x}$ \\
\hline Microtox ${ }^{0}$ testing of aquatic sediment & - & $\mathbf{x}$ & $\mathbf{x}$ & $\mathbf{x}$ \\
\hline Fathead minnow (48-hour $\left.\mathrm{LD}_{50}\right)^{\mathrm{c}}$ & - & $\mathbf{x}$ & - & - \\
\hline Daphnia stress (IQ) test & - & $\mathbf{x}$ & - & - \\
\hline Root elongation & $\mathbf{x}$ & - & $\mathbf{x}$ & - \\
\hline Earthworm toxicity & $\mathbf{x}$ & - & $\mathbf{x}$ & - \\
\hline Residue analyses & $\mathbf{x}$ & $\mathbf{x}$ & $\mathbf{x}$ & $\mathbf{x}$ \\
\hline Bioaccumulation, terrestrial & $\mathbf{x}$ & - & $\mathbf{x}$ & $\mathbf{x}$ \\
\hline Bioaccumulation, aquatic & - & $\mathbf{x}$ & $\mathbf{x}$ & $\mathbf{x}$ \\
\hline Tissue analyses & $\mathbf{x}$ & $\mathbf{x}$ & $\mathbf{x}$ & $\mathbf{X}$ \\
\hline
\end{tabular}

a An " $\mathrm{X}$ " indicates that the specified test is included in the ecological risk assessment to address one or more protective value; $a$ hyphen indicates that the test is not suitable to assess a particular protective value.

b This pathway is included as a separate item because the bald eagle is a species of special concern at both the federal and state levels.

c $\mathrm{LD}_{50}$ is the dose lethal to $50 \%$ of the test population. 
- A complete assessment of the status of federal- and state-listed species and of use of the quarry area by these species; and

- Toxicity tests (e.g., Microtox ${ }^{\circledR}$ screening, Daphnia, Lemna, fathead minnows, and earthworms).

Details on methods to meet the above data requirements are provided in the quarry residuals sampling plan (MK-Ferguson and Jacobs Engineering Group 1993b).

\subsection{PRELIMINARY IDENTIFICATION OF REGULATORY REQUIREMENTS}

A preliminary list of key environmental regulations and guidelines that may be pertinent to the QROU is presented in Table 18. As the RI/FS-EA process progresses, this list will be used to develop the "applicable or relevant and appropriate requirements" (ARARs) and "to-be-considered" requirements (TBCs) that could have a bearing on cleanup activities taken within the scope of this operable unit. An initial list of potential regulations is identified at this stage of the RI/FS-EA process for several reasons: to support the development of alternatives for the final quarry response, to initiate communication with and receive input from the state of Missouri and EPA Region VII on regulatory requirements important to activities conducted at the quarry area, and to support the planning of field activities.

Individual requirements that have been established pursuant to the regulations and guidelines listed in Table 18 can be divided into three categories: location-specific, contaminant-specific, and action-specific requirements. This categorization can be applied to plan coordinated response actions and track compliance for the QROU according to the specific contaminants that are present (such as uranium), discrete locations that are affected (such as wetlands and floodplains), and cleanup activities that could be taken (such as excavation and pumping). The preliminary list of regulations will be refined and the pertinence of specific requirements will be assessed as detailed information for the final quarry response becomes available.

The general process for developing and evaluating ARARs and TBCs is described in some detail in Appendix G of the FS that was recently completed for the chemical plant area of the site (DOE 1992b); many of the requirements associated with the regulations listed in Table 18 are also detailed in that discussion. Additional requirements that may be germane to the final response for the quarry area include contaminant-specific limits for water given in the Safe Drinking Water Act, the Clean Water Act, and parallel state laws. A detailed discussion of environmental requirements that are important to this final response will be presented in the FS to be prepared for the QROU. 
TABLE 18 Key Environmental Requirements and Guidelines Potentially Considered for the Final Quarry Response

\section{Federal Laws}

Archeological and Historic Preservation Act of 1974

Archeological Resources Protection Act of 1974

Atomic Energy Act of 1954, as amended

Clean Air Act of 1963, as amended

Clean Water Act, as amended (also referred to as Federal Water Pollution Control Act of 1972, as amended).

Endangered Species Act of 1973, as amended

Farmland Policy Protection Act of 1981, as amended

Fish and Wildlife Coordination Act of 1934, as amended

National Historic Preservation Act of 1966, as amended

Noise Control Act of 1972, as amended

Noise Pollution and Abatement Act of 1970

Safe Drinking Water Act of 1974

Soil and Water Resources Conservation Act of 1977

Solid Waste Disposal Act, as amended by the Resource Conservation and Recovery Act of 1976, as amended by the Hazardous and Solid Waste Amendments of 1984

Toxic Substances Control Act of 1976, as amended

Uranium Mill Tailings Radiation Control Act of 1978

\section{State Laws}

Missouri Air Pollution Control Regulations

Missouri Clean Air Act

Missouri Clean Water Act

Missouri Hazardous Substance Rules

Missouri Hazardous Waste Management Law and Regulations

Missouri Land Reclamation Act

Missouri Public Drinking Water Regulations

Missouri Radiation Regulations

Missouri Safe Drinking Water Act

Missouri Solid Waste Management Law

Missouri Wildlife Code

Missouri 401 Water Quality Certification

\section{Executive Orders}

Executive Order 11593, Protection and Enhancement of the Cultural Environment Executive Order 11988, Floodplain Mana rement

Executive Order 11990, Protection of Wetlands

Governor's Executive Order (Missouri) 82-19, Floodplain Management

\section{DOE Orders}

Order 5400.3, Hazardous and Radioactive Mixed Waste Program

Order 5400.5, Radiation Protection of the Public and the Environment

Order 5820.2A, Radioactive Waste Management 


\section{WORK PLAN RATIONALE}

The preliminary evaluation of site conditions at the QROU presented in Section 3 indicated that additional data need to be collected before decisions can be made regarding the course of action at this operable unit. Additional data will be collected as part of characterization activities performed in the RI phase to fill in the gaps summarized in Section 3.5. The data collected are intended to adequately characterize the quarry and its vicinity areas (i.e., the QROU), allow for an evaluation of current and future potential risks to human health and the environment, and aid in the identification of applicable remedial alternatives that can then be carried through a comparative analysis during the evaluation conducted in the FS phase.

To ensure that the requisite type, quantity, and quality of information is obtained to fulfill the objectives for this operable unit, a strategy for data acquisition was developed and is embodied in a seven-step process following a format recommended by the EPA (Neptune et al. 1990). The results of this planning process are commonly termed by the EPA as data quality objectives (DQOs). The characterization process will be undertaken in phases to harvest the full benefit of information collected in the initial phases of the investigation for refining sampling design for subsequent phases. Therefore, the intent of the discussion presented in Section 4.1 is to provide an overview of the strategy for the entire data collection program to support the RI/FS process being performed at the QROU. Detailed project DQOs including increasingly specific qualitative and quantitative statements of uncertainty and sampling design for achieving the overall goals established below will be defined in the appropriate phases of the investigation and will be documented in subsequent project reports. In general, data quality sufficient to meet risk assessment requirements - that is, equivalent to level IV as defined by EPA guidance (EPA 1988) - will be attained for the QROU.

\subsection{DATA QUALITY OBJECTIVES}

\subsubsection{Problem Statement}

The first step of the DQO planning process is to define the problem at hand; this involves providing a description of the problem and identifying any available background or supporting information that would help in defining the decision(s) that need to be made. Because of the history of disposal activities at the quarry and the contamination identified in the bulk waste and pond water currently being removed, it is anticipated that the residual material remaining at the quarry will need to be evaluated to determine whether or not it contains contaminants similar to those identified in the bulk waste and pond water. Further evaluation of the radioactive and chemical contaminant profiles for soil, surface water, sediment, and groundwater in the surrounding vicinity is also indicated. Limited data available to date for soil located at vicinity property 9 indicate elevated uranium levels (Section 2.4.2). Similarly, uranium contamination has also been indicated in the surface water and sediment of Femme Osage Slough (Sections 2.4.3 and 2.4.4). Also, groundwater 
monitoring results indicate the presence of radioactive and chemical contaminants in the groundwater (Section 2.4.6).

\subsubsection{Identifying the Decision}

The primary decision that needs to be made is whether or not contaminant levels in the various media at the QROU pose adverse impacts to human health and the environment and, therefore, require remediation. The nature and degree of impact, however, have to be evaluated in the context of current and projected plausible future land uses. On the basis of current knowledge regarding tine QROU, a conceptual site model was developed as a guide in the preliminary identification of potential pathways of exposure for both human receptors and biota (Section 3.1). Current land use at the areas comprising the QROU is basically limited to an occasional recreational visitor, primarily along Katy Trail; therefore, the potential for current adverse exposure to human health is considered minimal. Future land use is expected to remain consistent with current land use. The amount of information available on the biota of the area is too limited to support an initial evaluation of potential environmental impacts. Potential remedial options are presented in Section 3.4.

In addition to evaluating conditions at the QROU, the potential for groundwater contaminants present at the QROU to migrate to the nearby St. Charles County well field needs to be assessed. The future contaminant profile and concentrations would be estimated via modeling, and the potential for adverse impacts to human health from use of the water at the well field would be evaluated.

\subsubsection{Identifying the Input}

Information necessary to support decisions at the QROU are primarily the data gaps summarized in Section 3.5. Identification of the data gaps was based on the need for additional information to confirm the conceptual site model presented in Section 3.1. Because the residual material at the quarry floor is not accessible until the bulk waste has been removed, only after that removal is completed can the following be determined: the actual type of contamination, the particular media that are contaminated, and the amount of contamination that remains at the quarry proper. In addition, although soil in localized areas in the parcel of land immediately south of the quarry and north of the slough (i.e., vicinity property 9) contain uranium at elevated levels, the complete profile of radioactive and chemical contamination of this soil is not known. Further confirmation of the contamination of Femme Osage Slough surface water and sediment is also needed. Confirming contaminant profiles in the underlying groundwater includes refining background values of radioactive and chemical contaminants and defining the contaminant profiles in the alluvium and the bedrock formations (i.e., Decorah and Plattin). Hydrologic parameters also need to be obtained to define the hydrogeologic connection between the bedrock and the alluvium and between the groundwater and surface water. Additional data on the biota in this area are also needed before a definitive statement can be made regarding any potential environmental impacts from site contamination. 
Sampling conducted during the RI phase is expected to support remedial action decisions with regard to baseline risk in terms of providing the following data:

- Representative background concentrations for naturally occurring radionuclides, inorganic metals and anions from soil, surface water, sediment, and groundwater;

- A statistic (e.g., representative mean) representing radioactive and chemical contaminant concentrations in the residual material remaining at the quarry following removal of pond water and bulk waste;

- A statistic (e.g., representative mean) representing radioactive and chemical contaminant concentrations in upland and alluvial soils;

- A statistic (e.g., representative mean) representing radioactive and chemical contaminant concentrations in the alluvium and bedrock groundwater system;

- A statistic (e.g., representative mean) representing radioactive and chemical contaminant concentrations in surface water and sediment;

- Data defining the ecological communities present in the QROU; and

- Data assessing the impact of chemical and radioactive contaminants to critical biological receptors.

\subsubsection{Defining the Domain of the Decision}

On the basis of current and future land use projections (Sections 3.1 and 4.1.2), the following areas (and specific media) within and around the QROU have been identified for further contaminant investigation or sampling to evaluate potential risk to human health:

- The residual material at the quarry;

- Femme Osage Slough surface water and sediment (divided into east and west);

- Soil north of Femme Osage Slough (because of its size, this area may be divided into several areas for sampling and remedial decision purposes);

- Upland soil (north and east of the quarry);

- Little Femme Osage Creek and Femme Osage Creek surface water and sediment; and

- St. Charles County well field. 
The exposure to receptors identified for the specific areas of the QROU would be integrated across multiple areas and media of investigation, as appropriate. For example, a recreational visitor at the Femme Osage Slough area would be exposed to slough surface water and sediment as well as to soil to the south and north of the slough. More detailed discussion of potential pathways of exposure for the various potential receptors identified for the QROU are discussed in Section 3.1.

Ecological areas of investigations include:

- Riparian habitats adjacent to Femme Osage Slough;

- Riparian habitats adjacent to Little Femme Osage Creek, Femme Osage Creek, and the Missouri River;

- Upland habitats;

- Agricultural areas; and

- Aquatic habitat associated with Femme Osage Slough.

In addition to the spatial considerations of the investigations at the QROU, temporal sampling will also be needed to evaluate the groundwater contaminant profile concentrations before and after removal of the bulk waste at the quarry and to evaluate seasonal fluctuations of the surface water and sediment at the slough and creeks.

Groundwater flow and contaminant transport modeling will be used, as a quantitative tool, to predict future concentrations of potential contaminants of concern found in groundwater. An appropriate three-dimensional numerical model will be developed and calibrated to simulate flow and transport processes within the groundwater system. Results of the numerical modeling will be used to help determine, quantitatively, if there is potential for future exposure to contaminants in water from the St. Charles County well field.

\subsubsection{Decision Rule}

The primary use of data will be to conduct the baseline risk assessment. The determination of whether remedial action is required will be based, in part, on the results of that assessment. The EPA strives to manage possible incremental cancer risks at NPL sites within a target range of $10^{-6}$ to $10^{-4}$ and to maintain a hazard index (for noncarcinogenic effects) of less than 1 . However, additional factors, including risks associated with background concentrations of the naturally occurring contaminants of concern and limitations in analytical methods, are also taken into consideration in making a risk management decision to determine whether remedial action is necessary or warranted. Other factors taken into consideration include ARARs and the results of the ecological assessment. Should the decision be made that remedial action is required for one or more of the contaninated media at the QROU, the data would be utilized further to support the development and evaluation of remedial action alternatives. 
As part of initial planning activities, preliminary calculations were performed of media-specific (soil and groundwater) and contaminant-specific (for the preliminary contaminants of concern discussed in Section 3.1.2) reference concentrations corresponding to $10^{-6}$ to $10^{-4}$ risk and hazard quotients of $0.1,0.3,0.5$, and 1 , for a recreational scenario and residential scenario (for the groundwater pathway only) and are presented in the appendix. These risk-based values will be used to guide sampling design for determining key contributors to potential site risk. (The scope of sampling and analyses, however, will include confirmation of the presence or absence of all preliminary contaminants of concern identified for the QROU in Section 3.1.2).

The risk-based values in the appendix indicate that the issue of groundwater contamination may be more significant than that of soil. Soil contamination at the QROU may be of greater concern for its contribution to future groundwater contamination than for the pathways related to exposure to the soil directly. Therefore, information related to the nature and extent of soil contamination to determine the magnitude of this source will be important.

One interpretation of the preliminary results presented in the appendix is that potential key contributors to risk from groundwater contamination include the radionuclides, the nitroaromatic compounds, and several metals (arsenic, beryllium, and thallium). This observation is made on the basis of using the $10^{-4}$ risk level and/or a hazard index of 1 as a point of departure. Of these potential key contributors, to date only total uranium, arsenic, beryllium, 2,4-DNT, and 2,6-DNT have been detected at concentrations greater than their calculated concentrations corresponding to either the $10^{-4}$ risk level or hazard index of 1 , as presented in the appendix, Tables A.2, A.3, and A.4. On this basis, for initial sampling purposes, a tentative decision rule can be identified at the $10^{-4}$ risk level and a hazard index of 1 . This means that if the estimated overall site risk (considering all contaminants of concern) is greater than $10^{-4}$ or a hazard index of 1 , a decision to conduct remedial action can be supported. Conversely, if the actual overall site risk falls below these values, a decision not to remediate may be indicated. Ultimate risk management decisions, however, will need to consider other factors such as ARARs, cost, and available technologies. A more definitive decision rule will be identified for the QROU pending further evaluation of historical data and after confirmatory results are obtained from the initial phases of investigation.

\subsubsection{Developing Uncertainty Constraints}

Sampling at the QROU will be conservatively designed so that at the decision risk level, the probability of the occurrence of false negatives is very low and the probability of false positives is moderately low. In later phases of the investigation, more specific qualitative and quantitative statements of uncertainty will be defined on the basis of consequences of an incorrect decision. 


\subsubsection{Optimizing the Sampling Design}

Data collection activities at the QROU have been divided into sampling at areas outside of the quarry and sampling at the quarry proper. A sampling plan has been prepared describing the activities related to the collection of hydrogeological, contaminant, and ecological information for the areas outside of the quarry. A phased approach will be undertaken, and the objectives of these various phases as well as other details of the sampling activities are discussed in the quarry residuals sampling plan currently being prepared (MK-Ferguson Company and Jacobs Engineering Group 1993b). The general sampling activities currently planned are summarized in Section 4.3.

\subsection{DATA REQUIREMENTS}

An integral part of the strategy for data collection is the identification of the desired quality and quantity of analytical data so that the data generated are adequate to support risk assessment to a predetermined level of accuracy. The requirements for quality of data collected for any environmental activities undertaken within the project are presented and discussed in the Environmental Data Administration Plan (MK-Ferguson Company and Jacobs Engineering Group 1992d) for the site. This plan contains the minimum goals for precision, accuracy, representativeness, completeness, and comparability (PARCC) of any data set collected for the project, including those for the QROU. The specific PARCC goals for the data collected for the QROU are presented in the sampling plan prepared for this operable unit. In addition, the quantity of data required to meet the level of uncertainty defined will be attained by using statistical design as necessary and will be presented in subsequent sampling plans or project reports.

\subsection{SUMMARY OF QUARRY RESIDUALS SAMPLING PLAN}

A sampling plan is currently being prepared to detail data collection activities related to the hydrogeological, contaminant identification and quantification, and ecology of the areas outside of the quarry. Consequently, the summaries provided in Sections 4.3 .1 to 4.3 .3 are general in nature. However, a revision of these summaries will be provided in future drafts of this report to incorporate the details of the completed sampling plan.

\subsubsection{Hydrogeological Investigation}

The hydrogeological investigation for the quarry residuals $\mathrm{RI}$ describes those activities that will be undertaken to characterize the physical factors affecting the distribution, fate, and transport of contaminants in the QROU. The investigation addresses those activities necessary to complete an investigation of the area outside of the Weldon Spring quarry. Additional monitoring investigations to be undertaken by the project management contractor will address hydrogeological processes in the same study area (MK-Ferguson Company and Jacobs Engineering Group 1992g). Results from both the 
hydrogeological investigation and these monitoring investigations will be evaluated in conjunction with existing data and used, to the extent practicable, in the preparation of the RI, baseline risk assessment, and FS reports.

A general summary of the hydrogeological investigation is as follows:

- Geological Characterization -- The physical characteristics of the geologic media in the study area will be obtained from activities such as drilling, coring, and mapping. Fracture orientations will be measured in locally exposed units and compared with data obtained from coreholes advanced through the Decorah Group, Plattin Limestone, and Joachim Dolomite. Coring will also provide information on formation contacts and thicknesses in the study area.

- Hydrological Characterization - Water-level monitoring will be performed routinely on all monitoring wells and on Femme Osage Slough, the quarry pond, Little Femme Osage Creek, and the Missouri River. Additional monitoring wells are required to obtain physical and chemical data from the alluvium and the carbonate and clastic bedrock. Packer tests will be performed during drilling/coring of the proposed wells to obtain information on hydraulic conductivity within the bedrock units. Slug tests will be performed on all existing and proposed wells. Point dilution and tracer tests will be conducted in the alluvium to obtain information on groundwater flow velocity and dispersion. Precipitation, evaporation, other meteorological monitoring, and infiltration testing/ monitoring will be conducted to obtain site-specific information regarding climatic influences on the hydrologic system.

\subsubsection{Contaminant Sampling}

The first phase, or Phase I, contaminant sampling will be aimed at characterizing the nature, extent, and magnitude of chemical and radioactive contamination in each medium present in the areas outside of the quarry at the QROU (i.e., soil, sediment, surface water, and groundwater) prior to bulk waste removal. The QROU data gaps that are determined to be filled by other investigations (consistent with DQOs for the QROU) will be excluded from the sampling effort in Phase I. In addition, contaminant sampling will be developed in conjunction with the hydrogeological investigation. After preliminary investigations, the need for additional characterization and/or refinement of data previously collected may dictate subsequent additional phases subsequent to Phase I. During the initial sampling effort, statistical sampling will be applied, as appropriate; however, this application may be limited in scope to determine the nature and coefficient of variation of the contaminant distribution. Statistical applications in subsequent sampling design will be based on results from the initial phase. Background sampling needs will also be identified as part of Phase I sampling. 
In particular, data gap analysis and sampling needs will be addressed for soils in the alluvium both north and south of Femme Osage Slough. Sediment samples will be collected within Femme Osage Slough, Femme Osage Creek, and Little Femme Osage Creek. Additional surface water samples will be collected from the Femme Osage Slough, the Femme Osage Creek, and the Little Femme Osage Creek. Groundwater sampling will assess the horizontal and vertical extent of contamination within the Kimmswick Limestone, Decorah Group, and Plattin Limestone, as well as within the alluvium north and south of the slough and west of the quarry.

\subsubsection{Ecological Characterization}

The ecological characterization sampling plan specifies the activities to be conducted to complete a preliminary characterization of the ecology of the QROU, to facilitate comparison of the QROU ecology with background conditions, and to support an Ecological Risk Assessment. The plan describes the methodologies and rationale for conducting preliminary Phase I ecological characterization activities. These activities include vegetation surveys, herpetofauna surveys, surveys for federal or state listed birds, wetland delineation, and landsat thematic mapper (TM) imagery. Surveys will be conducted both at the QROU and at reference areas to facilitate comparison of the ecology of the QROU with background conditions. Surveys of birds, fish, small mammals, turtles, and benthic invertebrates have previously been conducted in the quarry area. Populations and community structure within these groups of organisms have been adequately characterized; therefore, additional survey activities regarding these biological groups are not identified as preliminary Phase I tasks.

Because the QROU is composed of diverse habitat types and biological communities, it has been partitioned into specific ecological study areas, including Little Femme Osage Creek; Femme Osage Creek; Femme Osage Slough; upland habitat; bottomland forest at Vicinity Property No. 9, Femme Osage Slough, Little Femme Osage Creek, and Femme Osage Creek; and agricultural fields. Appropriate reference areas have been identified for each of these study areas.

Vegetation surveys will be conducted to (1) characterize the plant communities and habitats present at QROU study areas and at reference study areas; (2) compare typical vegetation parameters measured at the QROU with those measured at the reference areas; (3) systematically investigate for the presence of threatened, endangered, or rare plant species; and (4) provide a preliminary evaluation of faunal food resources which may be at risk of contamination. Vegetation communities will be characterized and quantified at random sample points along line transects, using a combination of quadrants and pointcentered quarter sampling methods.

The primary objective for conducting herpetofauna surveys is to determine whether federal or state listed reptile or amphibian species occur in areas of known or suspected soil, surface water, or sediment contamination. Species richness and relative abundance of herpetofauna occurring in the QROU study areas will be compared with the same parameters 
associated with the reference areas. Survey methods to be used for the herpetofauna survey will include transect surveys, terrestrial trap arrays, artificial shelters, nighttime auditory surveys, and seining.

Surveys for listed birds will be conducted to determine whether bald eagles (Haliaeetus leucocephalus), loggerhead shrikes (Lanius ludovicianus), northern harriers (Circus cyaneus), and/or Swainson's hawks (Buteo swainsonii) actively use specific areas within the QROU for feeding, roosting, or nesting. These species have been selected for additional surveying due to their listed status and because they have been observed within the QROU.

Formal wetland delineation procedures will be conducted in areas along Femme Osage Creek, Little Femme Osage Creek, and Femme Osage Slough that are identified as wetlands on the U.S. Fish and Wildlife Service National Wetlands Inventory map.

Thematic mapper imagery will be used to aid in classifying and delineating habitat types, and in detecting areas of stressed vegetation (both upland and wetland). Data such as soil $\mathrm{pH}$, texture, and contaminant concentration will be used in the interpretation of TM imagery results to determine whether stresses on vegetation are related to the presence of contamination.

Additional ecological characterization activities may be deemed necessary or appropriate following a review of existing ecological information; existing analytical data; information obtained during the preliminary Phase I ecological characterization activities; and analytical data for soil, surface water, and sediment samples collected concurrently with Phase I ecological characterization activities. Potential additional activities, including toxicity testing and tissue analysis, are described in the ecological characterization sampling plan. These additional activities would be fully described in a supplementary Ecological Characterization Sampling Plan, prior to execution.

\subsection{SUMMARY OF OTHER SUPPORTING DOCUMENTS}

Other documents have been prepared and are already in place to support the RIFS-EA activities described in this work plan and the sampling plan. These are the community relations plan, the health and safety plans, and the environmental QAPP. The status and content of these plans are briefly summarized in Sections 4.4.1, 4.4.2, and 4.4.3, respectively.

\subsubsection{Community Relations Plan}

The existing community relations plan (MK-Ferguson Company and Jacobs Engineering Group 1992i) will be adopted for environmental compliance activities at the QROU. This plan describes the policy and procedures for site personnel interacting with the general public. The community relations program, as discussed in the plan, ensures 
meaningful exchanges of information on such matters as potential health impacts, environmental issues, response action construction plans, project costs, and specific site activities.

\subsubsection{Health and Safety Plans}

Health and safety plans will be developed for the QROU activities to ensure the health and safety of on-site personnel during the performance of site characterization and response action activities. The plans will include the safety standards that must be met by all personnel and subcontractors during the conduct of their assignments. Addressing the health and safety of on-site personnel will also minimize any potential impacts to the general public and the nearby environment. Key elements of these plans are the use of appropriate protective equipment and safeguards and the performance of specific tasks under the supervision of trained technicians and safety specialists. On-site personnel are trained to be cognizant of appropriate safety equipment and procedures, locations and types of on-site hazards, standard operating procedures, and procedures to be followed in emergency situations. Health and safety training and medical surveillance of all potentially exposed personnel are required elements of these plans.

A subcontractor involved with a project at the Weldon Spring site must comply with the health and safety plans and must prepare and comply with a safe work plan. The safe work plan covers health and safety aspects specific to the task performed.

\subsubsection{Environmental Quality Assurance Project Plan}

The quality assurance and quality control requirements implemented in activities such as sample collection for this operable unit are provided by the environmental QAPP (MK-Ferguson Company and Jacobs Engineering Group 1992h). This plan meets the applicable requirements of EPA's QAMS 005/80, Interim Guidelines and Specifications for tive Preparation of Quality Assurance Project Plans, by addressing the 16 quality assurance elements specified for environmentally related measurements (EPA 1983).

The data generated for the QROU are anticipated to be of such quality as to accurately define the nature and extent of radioactive and chemical contamination. The attainment of the desired quality of data is achieved through the implementation of standard operating procedures (SOPs) for activities, including the following: document control; field activities; chain of custody; equipment calibration; laboratory analyses; data validation, verification, reduction, and reporting; internal quality control checks; audits and surveillances; preventive maintenance; corrective actions; and document hierarchy.

The SOPs for field sampling are developed to standardize, where possible, sampling procedures to ensure that samples are comparable to, and compatible with, data collection activities at the Weldon Spring site. Available field SOPs include those for sample collection, 
sample identification, sample preservation, sample packaging and handling, sampling quality control, quality assurance, and equipment calibration and maintenance.

Procedures related to the management of environmental data are discussed in the Environmental Data Administration Plan prepared for the Weldon Spring site (MK-Ferguson Company and Jacobs Engineering Group 1992d). Laboratory QAPPs and SOPs are used to specify quality control requirements to demonstrate attainment of the specified PARCC goals. Chain-of-custody procedures to ensure and preserve sample integrity are also provided in the quality assurance program described in the environmental QAPP. Sample custody procedures are implemented in the field and laboratory and during record keeping.

The data generated are subjected to a estabi. . ed procedure of data evaluation, reduction, and reporting. Detailed descriptions of these procedures are presented in the environmental QAPP and associated SOPs. 


\section{REMEDIAL INVESTIGATION/FEASIBILITY STUDY TASKS}

The EPA has provided a framework consisting of 14 tasks to be performed during the RI/FS process. This framework will be used in carrying out a comprehensive program that addresses site investigation, risk assessment, and technologies and alternatives evaluation for the RI/FS-EA being undertaken for the QROU. Existing project documents, including the Project Management Contractor Quality Assurance Program (DOE 1992e), the Environmental Quality Assurance Project Plan (MK-Ferguson Company and Jacobs Engineering Group 1992h), and the Environmental Data Administration Plan (MK-Ferguson Company and Jacobs Engineering Group 1992d), will be used to direct and manage RI/FS-EA activities and implement $\mathrm{QA} / \mathrm{QC}$ requirements. These documents address applicable DOE and EPA requirements. The RI/FS tasks and the phased approach suggested by the EPA are presented in Figure 19. Site-specific activities carried out to fulfill each of the 14 tasks are discussed in Sections 5.1 through 5.14.

\subsection{TASK 1: PROJECT PLANNING}

The contents of this work plan and associated supporting documents - i.e., sampling and analysis plan(s), health and safety plan(s), and community relations plan - describe planning activities for the project. Activities under this task include:

- Collecting and evaluating available historical and characterization data or information (Section 2);

- Developing a conceptual site model on the basis of available information (Section 3.1);

- Identifying data needs and DQOs (Section 4.1);

- Identifying preliminary remedial action objectives and potential remedial alternatives (Section 3.3);

- Identifying treatability studies, as appropriate (Sections 1.3 and 5.7); and

- Identifying preliminary ARARs (Section 3.6).

\subsection{TASK 2: COMMUNITY RELATIONS}

Task 2 incorporates all efforts related to the preparation and implementation of the community relations plan (MK-Ferguson Company and Jacobs Engineering Group 1992i). This plan includes background information about the Weldon Spring site including the QROU, community relation strategies, lists of contacts and interested parties, and a 
REMEDIAL INVESTIGATION

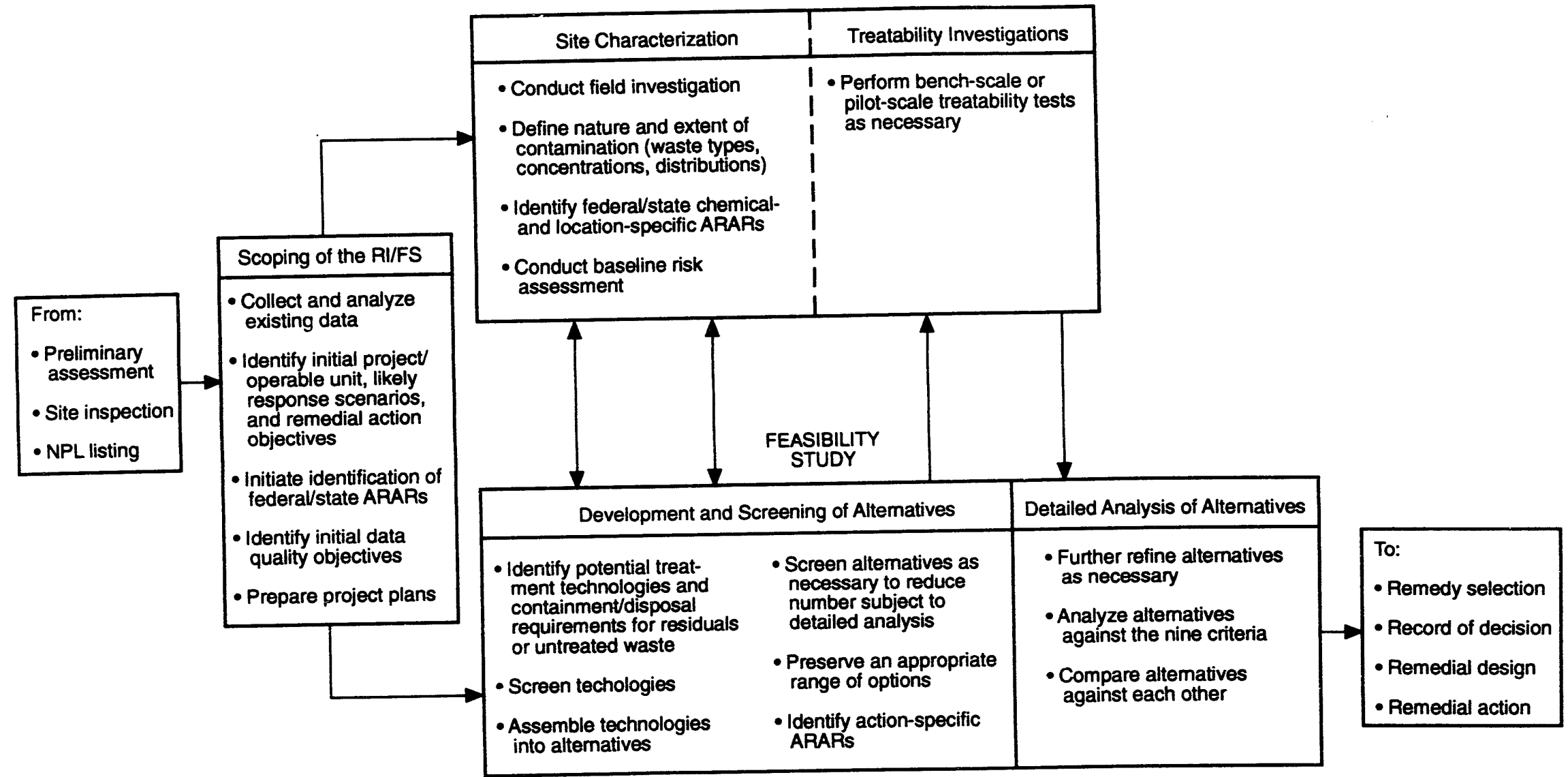

FIGURE 19 Summary Diagram of the RIFS Process (Source: EPA 1988) 
description of activities DOE is undertaking to ensure full public participation. So far, information related to site remedial activities has been provided to the public through news releases, fact sheets, public meetings, and briefings. The DOE will continue to use these mechanisms to inform the public regarding activities at the QROU. In addition, the public has access to various documentation related to the RI/FS-EA process for the QROU through several repository locations and at an on-site public reading room.

\subsection{TASK 3: FIELD INVESTIGATION}

Task 3 involves activities to be undertaken during the RI phase. Upon concurrence of the sampling and analysis plans by the EPA and state agencies, subcontractors will be procured. This task is complete when the subcontractors are demobilized from the field. The following activities will be conducted as part of this task:

- Mobilization of field activities;

- Media sampling;

- Source testing;

- Geological/hydrological investigations;

- Geophysical investigations;

- Geochemical investigations;

- Field measurements;

- Site surveys, topographic mapping, and aerial photography; and

- Ecological investigations.

Plans for field investigations are documented in field sampling plans. In accordance with the DQOs established for the QROU, sampling will be performed with a phased approach. A sampling plan is being developed for the areas outside of the quarry to fill the data gaps identified for those areas (Section 3.5). Basically, the data gaps for this operable unit have been categorized into those that will characterize the hydrogeological features, provide a contaminant profile of the various environmental media of concern, and characterize the ecological biota, to the extent practicable.

\subsection{TASK 4: SAMPLE ANALYSIS AND VERIFICATION}

For Task 4, samples collected during the field investigation will be analyzed in accordance with the data quality requirements (DQRs) established for this operable unit. The DQRs are described in more detail in the sampling plans. 
The verification program is designed primarily to ensure that documentation and data are reported in compliance with established DQRs and SOPs. The sample verification process includes a review of sample identification and preservation, chain-of-custody documentation, analytical holding times, and completeness of data reported.

Validation of the data collected is also performed to ensure that the quality of data acquired is adequate for its intended use and is in compliance with the DQRs established. Procedures covering this task are described in the Environmental Data Administration Plan (MK-Ferguson and Jacobs Engineering Group 1992d) prepared for the Weldon Spring site.

\subsection{TASK 5: DATA EVALUATION}

Task 5 involves analysis of the data after verification and validation activities have been performed. The task begins when the first set of validated data is received and ends during preparation of the RI report or supplemental investigation when it is determined that no additional data are required. The following activities are typically performed under Task 5:

- Comparing potential site-related contaminant concentrations with background values; and

- Developing a data set for use in the baseline risk assessment.

\subsection{TASK 6: RISK ASSESSMENT}

Task 6 includes effort related to the performance of a baseline risk assessment for the QROU. This assessment will analyze, for current and future land uses, the potential adverse human health and environmental effects caused by contaminants identified at the QROU. The results of the assessment will be used to support activities related to the screening of alternatives and development of cleanup limits for radioactive and chemical constituents. The activities that will be performed and presented in a baseline risk assessment report include those related to (1) identification of the contaminants of concern for the QROU, from the standpoint of both human health and ecological concerns; (2) exposure assessment, including modeling as appropriate; (3) toxicity assessment; and (4) risk characterization.

In addition to historical information, data gathered from characterization activities during the RI will be evaluated according to procedures recommended by the EPA (1989b, 1989c) to identify the contaminants of concern. This same subset of data will also be used to derive the exposure point concentrations for the identified contaminants of concern. Factors needed to perform the exposure assessment will be site-specific to the extent possible, or derived from EPA-recommended sources. Toxicity values are available from the EPA through the Integrated Risk Information System database; reference doses and slope factors for the appropriate chemical contaminants of concern will be obtained from this database. 
Although the EPA has recently developed cancer factors per unit intake for radioactive contaminants that are analogous to slope factors for chemical carcinogens, these factors will not be used to estimate risks from exposure to radioactive contaminants because these factors have not been independently verified nor have they been widely used. Rather, radiological risks will be estimated on the basis of dose conversion factors (i.e., $\mathrm{mrem} / \mathrm{pCi}$ ) and unit risk factors (i.e., risk/mrem), as discussed in Section 4.1 of the BA for the chemical plant area (DOE 1992c). Chemical and radiological risks will be analyzed separately to allow for a clear presentation of the source of risk, i.e., radiological or chemical.

\subsection{TASK 7: TREATABILITY STUDIES}

Task 7 is performed to provide information needed for alternatives to be fully developed and evaluated during the RI/FS-EA process. Treatability studies can provide data important to an adequate evaluation of certain technologies for a given response action including information on performance, operating parameters, and cost in sufficient detail to support the remedy selection process and subsequent design activities. This task can involve efforts for bench-scale or pilot-scale tests, including associated procurement activities. Treatability studies can be identified at different times during the RI/FS-EA process, e.g., from the scoping stage through the screening of preliminary alternatives.

One treatability study has been identified during the scoping phase for this QROU. A pilot-scale study is being considered to evaluate the potential for collecting contaminated groundwater from the quarry area, e.g., with a pumping well and/or interceptor trench system, for subsequent treatment at the quarry plant. A separate treatability work plan is being developed for this study, which would involve focused characterization activities and is expected to provide information on the feasibility of potential collection systems, the appropriateness of the available treatment system, and aquifer responise testing, as well as some additional data on groundwater monitoring. Additional treatability studies; including post-screening investigations, would be developed as this RI/FS-EA process proceeds if additional data needs are identified. Such studies would be conducted to support the aralysis of alternatives with respect to technology availability and technical and administrative feasibility for site-specific application.

\subsection{TASK 8: REMEDIAL INVESTIGATION REPORT}

Task 8 involves the activities undertaken to prepare and complete the RI report for this operable unit. The format of this report will be similar to previous RI reports prepared for the project (DOE 1989, 1992d). This report is expected to include the following:

- A complete description of the areas that comprise the QROU;

- A brief site history and origin of contamination to lend rationale for the characterization activities completed; 
- A summary of all relevant data, including those not collected from the characterization effort that is the subject of this RI; and

- A summary of the baseline risk assessment performed for the QROU. A separate report will be prepared to present the analysis and results of the baseline risk assessment performed for this operable unit.

\subsection{TASK 9: REMEDIAL ALTERNATIVES DEVELOPMENT AND SCREENING}

Task 9 involves screening the initial development and evaluation of remedial action alternatives for the QROU that will be fully evaluated under Task 10 . The objective of the screening process undertaken within Task 9 is to narrow the number of alternatives that will undergo detailed evaluation. This process begins with identification of the remedial action objectives, then proceeds through narrowing of the potential technologies on the basis of applicability and effectiveness, and ends with identification of a set of remedial action alternatives. Each remedial action alternative may involve application of a single technology or a combination of two or more technologies. Task 9 consists of the following activities:

- Identifying response objectives and response actions;

- Listing potential remedial technologies;

- Screening remedial technologies and process options on the basis of site-specific criteria;

- Assembling potential remedial action alternatives from the screened technologies and process options;

- Evaluating potential remedial action alternatives on the basis of screening criteria (i.e., effectiveness, implementability, and cosit); and

- Identifying candidate remedial action alternatives for detailed evaluation in Task 10.

\subsection{TASK 10: DETAILED ANALYSIS OF ALTERNATIVES}

The remedial alternatives that pass the screening process during Task 9 will be evaluated in detail within Task 10 . The criteria for evaluating these alternatives are as follows:

- Overall protection of human health and the environment;

- Compliance with ARARs;

- Long-term effectiveness and permanence; 
- Reduction of toxicity, mobility, and volume;

- Short-term effectiveness;

- Implementability;

- Cost;

- Acceptance by the state; and

- Acceptance by the community.

A summary of each alternative, including the no-action alternative, is prepared on the basis of these nine criteria. Use of these nine criteria is consistent with the NCP.

\subsection{TASK 11: FEASIBILITY STUDY REPORT}

Task 11 involves the coordination and preparation of the FS report. The task is complete when the FS report is released to the public. The following are activities under this task:

- Formatting data for report purposes;

- Preparing associated graphics;

- Writing the report;

- Printing and distributing the report;

- Responding to review comments; and

- Revising the report on the basis of agency comments.

The format of the FS report for the QROU will be similar to previous FS reports prepared for the project (DOE 1990b, 1992b). The report will incorporate NEPA values to reflect the level of analysis in an EA.

\subsection{TASK 12: POST-REMEDIAL INVESTIGATION/FEASIBILITY STUDY SUPPORT}

Task 12 includes efforts to prepare the proposed plan and responsiveness summary, support development of the ROD, and conduct any predesign activities. Task 12 activities include:

- Preparing the proposed plan;

- Attending public meetings; 
- Preparing the responsiveness summary and draft ROD;

- Finalizing documents in response to agency and public comments;

- Preparing the predesign report; and

- Completing the conceptual design.

The proposed plan is a summary document that identifies the preferred remedial action alternative and the rationale for selection, describes the alternatives evaluated in the RI/FS-EA, and solicits public review and comment on all screened alternatives presented in the FS. The format of the proposed plan for the QROU will be similar to previous proposed plans for the project (DOE 1990c, 1992c). Preparation of the responsiveness summary and ROD will be initiated following public review of the RI/FS-EA.

\subsection{TASK 13: ENFORCEMENT SUPPORT}

Task 13 includes efforts during the RI/FS-EA process associated with enforcement aspects of the project, typically concerning potentially responsible parties. Because DOE has assumed responsibility for the Weldon Spring site, including the QROU, Task 13 is not applicable to the Weldon Spring project.

\subsection{TASK 14: MISCELLANEOUS SUPPORT}

Task 14 is used to report on work that is associated with the project but does not fall under any of the other established RI/FS-EA tasks. No activities under this task have been identified for the QROU. 


\section{PROJECT SCHEDULE}

The overall schedule for the environmental compliance activities planned for the QROU is shown in Figure 20. This schedule was developed in accordance with the project financial plan for fiscal year 1993 and shows the events projected through the point at which the ROD is issued. This schedule shows the relationships between the tasks and their projected durations.

A key factor considered in the overall schedule planning of the RI/FS-EA process for the QROU is the removal of bulk waste currently located in the quarry; this removal is tentatively scheduled to be completed mid-1995. The schedule presented in Figure 20 accommodates the bulk waste removal schedule and also allows for a reasonable amount of time to elapse so that data (primarily groundwater monitoring data) can be collected and evaluated, after the bulk waste (which is considered to be a primary source of historical contamination at the quarry area) has been removed. Specific dates beyond 1993 should not be considered as firmly established, however, because funding is based on the out-year budget cycle. The project schedule consists of the following major components:

- Completion of scoping and planning for the QROU. Scoping involves the early incorporation of public comment and concerns into the RI/FS-EA process. This may include, for example, consideration of specific remedies for site cleanup or evaluation of various health and environmental concerns. Documentation for the QROU during the scoping phase includes this RI/FS-EA work plan and the sampling and analyses plans.

- Completion of characterization activities.

- Completion of the RI/FS-EA process and issuance for public comment of the RI report, the baseline risk assessment report, the FS report, and the proposed plan.

- Preparation of a responsiveness summary to address public comments received on the RI/FS-EA reports, and preparation and issuance of the ROD. The ROD is projected to be issued in 1998. Remedial design and remedial action consistent with the NCP will be initiated following issuance of the ROD. 


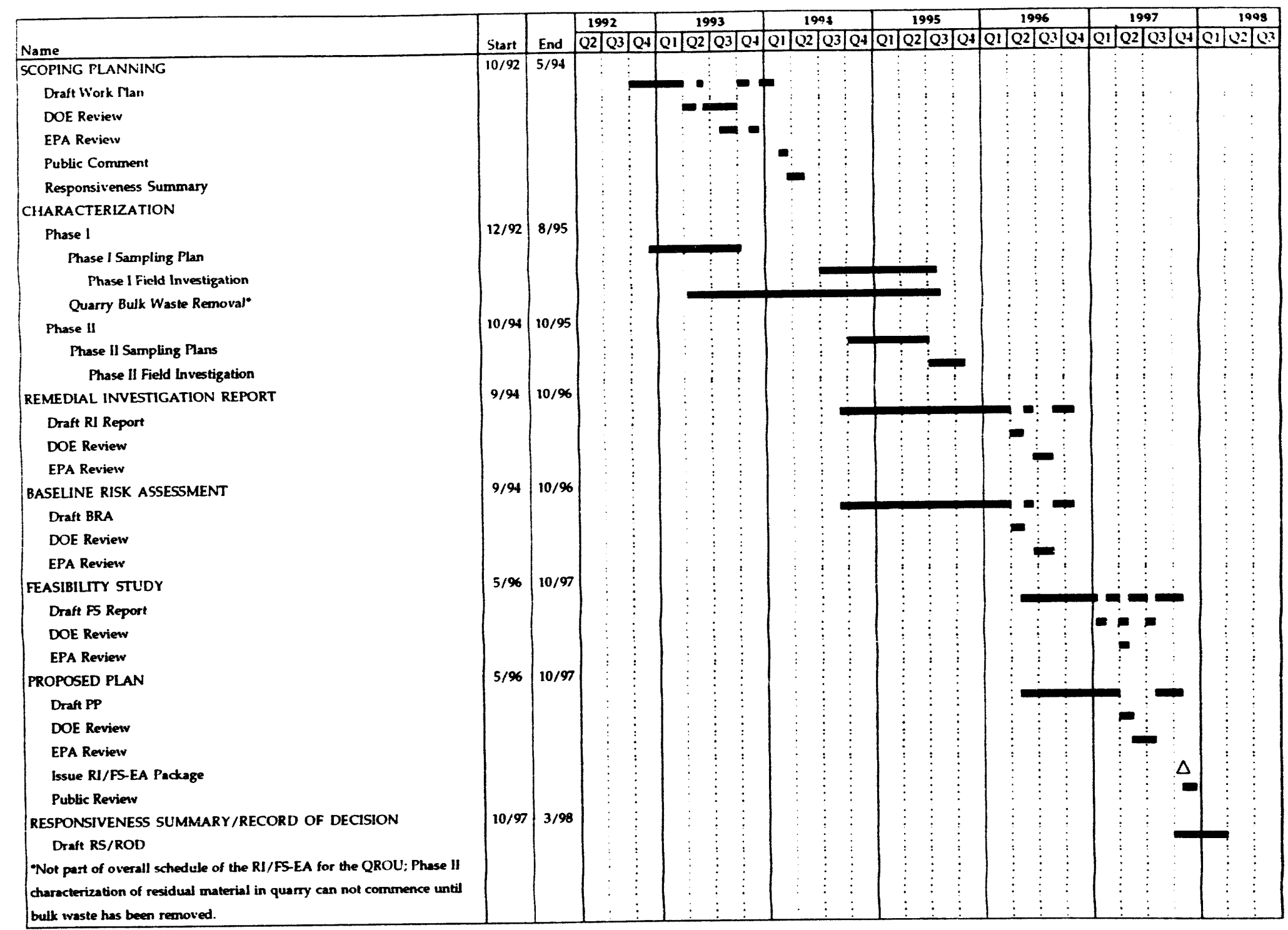

FIGURE 20 RIFS-EA Schedule for the Quarry Residuals Operable Unit 


\section{PROJECT MANAGEMENT}

\subsection{PROJECT ORGANIZATION}

Remedial action at the QROU is being conducted by DOE under the Weldon Spring Site Remedial Action Project, which is administered by the Eastern Area Programs Division of the Office of Environmental Restoration (Figure 21). This division is responsible for policy decisions related to conducting remedial actions at the Weldon Spring site and for coordination with the U.S. Department of the Army, which shares the cost of this project. Responsibility for management and technical direction of remedial action activities for the Weldon Spring site has been delegated to the DOE Oak Ridge Operations Office, which has established a project office at the Weldon Spring site.

Four separate organizations are under contract to the DOE to support implementation of this project:

- MK-Ferguson Company is the Project Management Contractor, assisting DOE in the planning and management of response action activities; Jacobs Engineering Group, Inc., is under contract to MK-Ferguson to provide technical support for the project.

- Argonne National Laboratory, Environmental Assessment Division, is the CERCLA/NEPA process management contractor and is responsible for planning and preparing appropriate environmental compliance documentation to support specific cleanup decisions.

- Oak Ridge Associated Universities provides technical support, specifically by performing independent verification of completed response actions.

- Professional Analysis Inc. of Oak Ridge, Tennessee, provides administrative support to the DOE project office.

\subsection{PROJECT COORDINATION AND RESPONSIBILITIES}

Remedial actions carried out by DOE at the Weldon Spring site are subject to EPA oversight under CERCLA. Oversight responsibilities for the Weldon Spring site are carried out by EPA Region VII. The responsibilities of DOE and EPA are defined in the FFA in place for the Weldon Spring site.

The state of Missouri has designated the Missouri Department of Natural Resources to coordinate state involvement in whis project. This department is responsible for ensuring that the appropriate state agencies are kept informed regarding project plans and activities. 


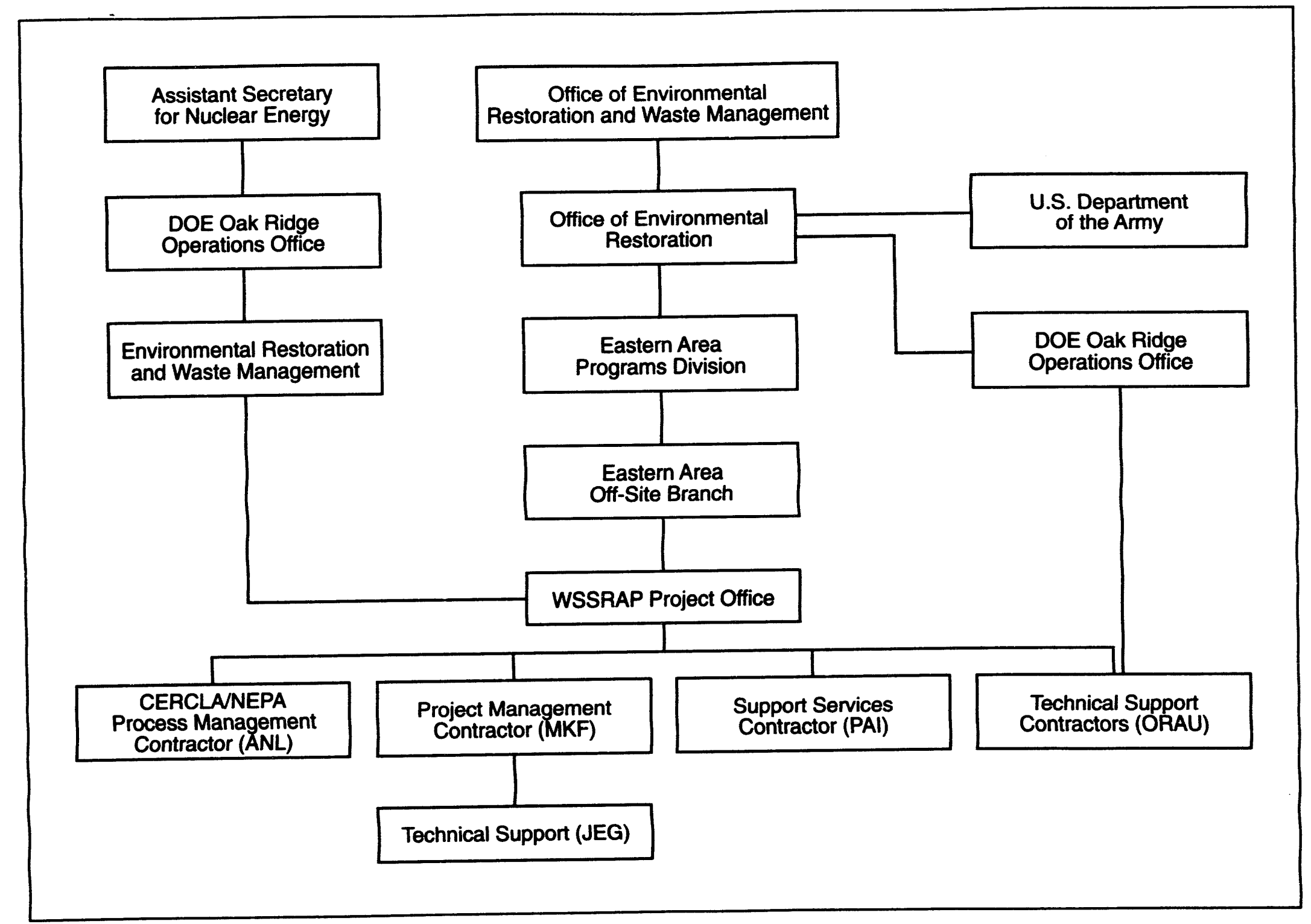


The responsibilities of each of the major organizations under contract to the DOE at the Weldon Spring site are as follows:

- MK-Ferguson Company (including Jacobs Engineering Group, Inc., as a subcontractor)

- Provide overall project management support to DOE for the Weldon Spring Site Remedial Action Project. This support includes implementation and documentation of activities related to health and safety requirements (Section 4.4.2), cost control procedures, sample and data management, project schedule tracking, and training.

- Administer procurement and quality assurance functions.

- Perform general administrative functions.

- Direct all engineering activities.

- Provide technical input to the preparation of environmental documents.

- Perform community relations duties.

- Argonne National Laboratory, Environmental Assessment Division

- Plan and perform environmental analyses for CERCLA and NEPA compliance.

- Provide an independent analysis of environmental studies, engineering feasibility, and cost-effectiveness of response action alternatives performed by other DOE contractors.

- Prepare additional environmental compliance documentation, as needed.

- Oak Ridge Associated Universities

- Conduct radiological surveys to identify and designate vicinity properties that require response actions.

- Conduct post-response radiological surveys to provide independent verification of the cleanup effort and prepare the requisite verification reports. 
- Professional Analysis Inc.

- Provide technical and administrative support to the DOE project office.

- Review environmental documents and advise the DOE project office on regulatory requirements.

- Review and analyze resources as changes in funding and priorities occur.

- Assist the DOE project office with the preparation and/or analysis of documents and reports for the annual budget process. 


\section{REFERENCES}

Bailey, R.G., 1978, Description of the Ecoregions of the United States, U.S. Forest Service, Intermountain Region, Ogden, Utah.

Bair, F.E., 1992, The Weather Almanac, 6th ed., Gale Research Inc., Detroit, Mich.

Bechtel National, Inc., 1983, Weldon Spring Site (WSS) Environmental Monitoring Report, Calendar Year 1982, prepared for U.S. Department of Energy, Oak Ridge Operations Office, Oak Ridge, Tenn., July.

Bechtel National, Inc., 1987, Hydrogeological Characterization Report for Weldon Spring Chemical Plant, Weldon Spring, Missouri, DOE/OR/20722-137, prepared for U.S. Department of Energy, Oak Ridge Operations Office, Oak Ridge, Tenn., July.

Bedan, D.E., 1991, letter from D.E. Bedan (Radioactive Waste Cleanup Coordinator, Division of Environmental Quality, Missouri Department of Natural Resources, Jefferson City, Mo.) to S. McCracken (Project Manager, U.S. Department of Energy, Weldon Spring Remedial Action Project, St. Charles, Mo.), April 12.

Berkeley Geosciences Associates, 1984, Characterization and Assessment for the Weldon Spring Quarry Low-Level Radioactive Waste Storage Site, prepared by Berkeley Geosciences Associates, Berkeley, Calif., for Oak Ridge National Laboratory, Oak Ridge, Tenn., Sept.

Bodek, I., et al. (editors), 1988, Environmental Inorganic Chemistry: Properties, Processes, and Estimation Methods, Pergamon Press, New York, N.Y., p. 2.12-1.

Boerner, A.J., 1986, Radiological Survey of the August A. Busch and Weldon Spring Wildlife Areas, Weldon Spring Site, St. Charies County, Missouri, Final Report, prepared by Oak Ridge Associated Universities, Oak Ridge, Tenn., for U.S. Department of Energy, April.

Chapman, C.H., 1975, The Archaeology of Missouri I, University of Missouri Press, Columbia.

Chapman, C.H., 1980, The Archaeology of Missouri II, University of Missouri Press, Columbia.

Crigler, D., 1992, personal communication from D. Crigler (Wildlife Management Biologist, August A. Busch Wildlife Area, St. Charles, Mo.) to G. Valett (Project Management Contractor, Weldon Spring Site Remedial Action Project, St. Charles, Mo.), as documented in memorandum from G. Valett to R. Ferguson (Jacobs Engineering Group, Weldon Spring Site Remedial Action Project, St. Charles, Mo.), May 21.

Daubel, K., 1992, personal communication from K. Daubel (U.S. Department of Army) to M. Sizemore (MK-Ferguson Company, Weldon Spring Site Remedial Action Project, St. Charles, Mo.), as documented in memorandum from M. Sizemore to M. MacDonell (Environmental Assessment and Information Sciences Division, Argonne National Laboratory, Argonne, Ill.), March 17. 
Dickneite, D.F., 1988, letter from D.F. Dickneite (Environmental Administrator, Missouri Department of Conservation, Jefferson City, Mo.) to I. Hlohowskyj (Argonne National Laboratory, Argonne, Ill.), with enclosure, Aug. 24.

DOE: see U.S. Department of Energy.

Ellis, H.V., et al., 1979, Mammalian Toxicity of Munitions Compounds, Phase III: Effects of Lifetime Exposure, Part 1: 2,4-Dinitrotoluene, Contract No. DAMD17-74-C-4073, Midwest Research Institute, Kansas City, Mo.

Environmental Science and Engineering, Inc., 1993, Weldon Spring Remedial Action Project 1992 Aquatic Biological Monitoring - WP 305, Final Report, ESE No. 592-1043-0400, prepared by Environmental Science and Engineering, Inc., St. Louis, Mo., for MK-Ferguson Company, St. Charles, Mo., April.

EPA: see U.S. Environmental Protection Agency.

Federal Insurance Administration, undated, "Flood Insurance Rate Map, St. Charles County, Missouri," map panel 290315 0100B, U.S. Department of Housing and Urban Development, National Flood Insurance Program.

Figg, D.E., 1991, letter from D.E. Figg (Endangered Species Coordinator, Missouri Department of Conservation, Jefferson City, Mo.) to J.R. Powers (MK-Ferguson Company, St. Charles, Mo.), Nov. 26.

Freeze, R.A., and J.A. Cherry, 1979, Groundwater, Prentice-Hall, Inc., Englewood Cliffs, N.J.

Furedi, E.M., et al., 1984, Determination of Chronic Mammalian Toxicological Effects of TNT (Twenty-Four Month Chronic Toxicity/Carcinogenicity Study of Trinitrotoluene [TNT] in the Fischer 344 Rat), U.S. Army Medical Research and Development Command, Fort Detrick, Frederick, Md.

Gaines, E.P., 1988, letter from E.P. Gaines (Data Manager, Missouri Department of Conservation, Jefferson City, Mo.) to I. Hohowskyj (Argonne National Laboratory, Argonne, Ill.), with enclosure, Sept. 8.

Gilbert, T.L., et al., 1989, A Manual for Implementing Residual Radioactive Material Guidelines, ANL/ES-160 (DOE/CH/8901), prepared by Argonne National Laboratory, Energy and Environmental Systems Division, Argonne, Ill., for U.S. Department of Energy, Assistant Secretary for Nuclear Energy, June.

Haas, D., 1978, An Archaeological Survey of the Little Femme Osage/River Hills Area and the Loutre River Valley: A Multivariate Approach to Environment and Site Distributions in the Lower Missouri Valley II Locality, American Archaeology Division, Department of Anthropology, University of Missouri-Columbia, Columbia, Mo. 
Huey, E.A., 1978, Report on Preliminary Geological, Hydrological and Radiological Survey at the Weldon Spring Quarry during 1976 and 1977, Feed Materials Production Center, National Lead Company of Ohio, Dec. 14.

Kleeschulte, M.J., 1993, Water-Quality Data for the Missouri River and Missouri River Alluvium near Weldon Spring, St. Charles County, Missouri - 1991-92, U.S. Geological Survey Open File Report 93-109.

Kleeschulte, M.J. and L.F. Emmett, 1986, Compilation and Preliminary Interpretation of Hydrologic Data for the Weldon Spring Radioactive Waste-Disposal Site, St. Charles County, Missouri-A Progress Report, U.S. Geological Survey Water-Resources Investigation Report 85-4272.

Kleeschulte, M.J., and L.F. Emmett, 1987, Hydrology and Water Quality at the Weldon Spring Radioactive Waste-Disposal Sites, St. Charles, Missouri, U.S. Geological Survey WaterResources Investigation Report 87-4169.

Knight, M.J., 1983, Uptake by Plants of Radionuclides from FUSRAP Waste Materials, ANL/EIS-19, prepared by Argonne National Laboratory, Argonne, Ill, for U.S. Departınent of Energy, Oak Ridge Operations Office, Oak Ridge, Tenn., April.

Layne Western Company, Inc., 1986, Groundwater Hydrology Investigation, Weldon Spring, Mo., Volumes I-III, Hydrology Division, Kansas City, Kansas, Jan. 8.

Lenhard, J.A., et al., 1967, Weldon Spring Raffinate Pits and Quarry Task Force Report, prepared for U.S. Atomic Energy Commission, Oak Ridge Operations Office, Oak Ridge, Tenn., June 1.

MacDonell, M.M., et al., 1989, Engineering Evaluation/Cost Analysis for the Proposed Management of Contaminated Water in the Weldon Spring Quarry, DOE/OR/21548-039, prepared by Argonne National Laboratory, Energy and Environmental Systems Division, Argonne, Mlinois, for the U.S. Department of Energy, Oak Ridge Operations Office, Weldon Spring Site Remedial Action Project, Weldon Spring, Missouri, Jan.

March, D.D., 1967, The History of Missouri, 2 vols., Lewis Historical Company, New York, N.Y.

Marutzky, S.J., et al., 1988, Radiological Characterization of the Weldon Spring, Missouri, Remedial Action Site, UNC/GJ-HMWP-4 (DOE/ID/12548-22), prepared by UNC Geotech, Inc., Grand Junction, Colo., for U.S. Department of Energy, Weldon Spring Site Remedial Action Project, Weldon Spring, Mo., with Grand Junctions Projects Office, Grand Junction, Colo., Feb.

Meyer, K, 1988, "Previous WSQ Soil Sampling," interoffice correspondence from K. Meyer (MK-Ferguson Company, Weldon Spring, Mo.) to distribution, April and June. 
Missouri Department of Conservation, 1990, Recreational Use of Weldon Spring Wildlife Area 1989-1990, Jefferson City, Mo.

Missouri Department of Conservation, 1992, Rare and Endangered Species of Missouri Checklist, Jefferson City, Mo.

Missouri Department of Natural Resources, 1991, The Missouri Safe Drinking Water Act and the Missouri Public Drinking Water Regulations, Public Drinking Water Program, Jefferson City, Mo.

MK-Ferguson Company, 1987, Water Quality Phase I Assessment Report, DOE/OR/21548-003, prepared for U.S. Department of Energy, Oak Ridge Operations Office, Weldon Spring Site Remedial Action Project, St. Charles, Mo., Dec.

MK-Ferguson Company and Jacobs Engineering Group, 1988, Annual Environmental Monitoring Report, Weldon Spring, Missouri, Calendar Year 1987, DOE/OR/21548-015, prepared for U.S. Department of Energy, Oak Ridge Operations Office, Weldon Spring Site Remedial Action Project, St. Charles, Mo., Nov.

MK-Ferguson Company and Jacobs Engineering Group, 1989a, Annual Environmental Monitoring Report 1988, DOE/OR/21548-079, Rev. 0, prepared for U.S. Department of Energy, Oak Ridge Operations Office, Weldon Spring Site Remedial Action Project, Weldon Spring, Mo., June.

MK-Ferguson Company and Jacobs Engineering Group, 1989b, Characterization of Chemical and Radiological Contamination in Lake and Stream Sediments on Properties Surrounding the Weldon Spring Site, DOE/OR/21548-060, Rev. 0, prepared for U.S. Department of Energy, Oak Ridge Operations Office, Weldon Spring Site Remedial Action Project, Weldon Spring, Mo., Aug.

MK-Ferguson Company and Jacobs Engineering Group, 1989c, Phase I Spring and Seep Report, DOE/OR/21548-045, Rev. 0, prepared for U.S. Department of Energy, Oak Ridge Operations Office, Weldon Spring Site Remedial Action Project, St. Charles, Mo., Aug.

MK-Ferguson Company and Jacobs Engineering Group, 1990a, Annual Site Environmental Report 1989, DOE/OR/21548-129, Rev. 1, prepared for U.S. Department of Energy, Oak Ridge Operations Office, Weldon Spring Site Remedial Action Project, Weldon Spring, Mo., Nov.

MK-Ferguson Company and Jacobs Engineering Group, 1990b, Environmental Monitoring Plan, DOE/OR/21548-103, Rev. 1, prepared for U.S. Department of Energy, Oak Ridge Operations Office, Weldon Spring Site Remedial Action Project, Weldon Spring, Mo., Feb.

MK-Ferguson Company and Jacobs Engineering Group, 1991a, Annual Site Environmental Report for Calendar Year 1990, DOE/OR/21548-193, Rev. 1, prepared for U.S. Department of Energy, Oak Ridge Operations Office, Weldon Spring Site Remedial Action Project, St. Charles, Mo., Sept. 
MK-Ferguson Company and Jacobs Engineering Group, 1991b, Environmental Monitoring Plan for Calendar Year 1991, DOE/OR/21548-174, Rev. 0, prepared for U.S. Department of Energy, Oak Ridge Operations Office, Weldon Spring Site Remedial Action Project, Weldon Spring, Mo., Jan.

MK-Ferguson Company and Jacobs Engineering Group, 1991c, Aquatic Biological Screening Investigation, DOE/OR/21548-__, Rev. A, prepared for U.S. Department of Energy, Oak Ridge Operations Office, Weldon Spring Site Remedial Action Project, Weldon Spring, Mo., April.

MK-Ferguson Company and Jacobs Engineering Group, 1992a, Environmental Monitoring Plan for Calendar Year 1992, DOE/OR/21548-237, Rev. 1, prepared for U.S. Department of Energy, Oak Ridge Operations Office, Weldon Spring Site Remedial Action Project, Weldon Spring, Mo., Jan.

MK-Ferguson Company and Jacobs Engineering Group, 1992b, General Universal Report Utility, database for Weldon Spring Site Remedial Action Project, St. Charles, Mo., accessed October.

MK-Ferguson Company and Jacobs Engineering Group, 1992c, Weldon Spring Site Environmental Report for Calendar Year 1991, DOE/OR/21548-283, Rev. 1, prepared for U.S. Department of Energy, Oak Ridge Operations Office, Weldon Spring Site Remedial Action Project, Weldon Spring, Mo., July.

MK-Ferguson Company and Jacobs Engineering Group, 1992d, Environmental Data Administration Plan, DOE/OR/21548-119, prepared for U.S. Department of Energy, Oak Ridge Operations Office, Weldon Spring Site Remedial Action Project, Weldon Spring, Mo., Feb.

MK-Ferguson Company and Jacobs Engineering Group, 1992e, Concentration Ratios of Radionuclides in the U-238, U-235, and Th-232 Decay Series, DOE/OR/21548-250, Rev. 0, prepared for U.S. Department of Energy, Oak Ridge Operations Office, Weldon Spring Site Remedial Action Project, Weldon Spring, Mo., Sept.

MK-Ferguson Company and Jacobs Engineering Group, 1992f, Environmental Monitoring Plan for Calendar Year 1993, DOE/OR/21548-349, Rev. 0, prepared for U.S. Department of Energy, Oak Ridge Operations Office, Weldon Spring Site Remedial Action Project, Weldon Spring, Mo., Dec.

MK-Ferguson Company and Jacobs Engineering Group, 1992g, Weldon Spring Quarry Supplementary Environmental Monitoring Investigations Sampling Plan, DOE/OR/21548-264, Rev. B, prepared for U.S. Department of Energy, Oak Ridge Operations Office, Weldon Spring Site Remedial Action Project, St. Charles, Mo., April.

MK-Ferguson Company and Jacobs Engineering Group, 1992h, Environmental Quality Assurance Project Plan, DOE/OR/21548-352, Rev. 0, prepared for U.S. Department of Energy, Oak Ridge Operations Office, Weldon Spring Site Remedial Action Project, Weldon Spring, Mo., Oct. 
MK-Ferguson Company and Jacobs Engineering Group, 1992i, Community Relations Plan, DOE/OR/21548-009, Rev. 6, prepared for U.S. Department of Energy, Oak Ridge Operations Office, Weldon Spring Site Remedial Action Project, St. Charles, Mo., Sept.

MK-Ferguson Company and Jacobs Engineering Group, 1993a, Weldon Spring Site Environmental Report for Calendar Year 1992, DOE/OR/21548-372, Rev. A, prepared for U.S. Department of Energy, Oak Ridge Field Office, Weldon Spring Site Remedial Action Project, St. Charles, Mo., March.

MK-Ferguson Company and Jacobs Engineering Group, 1993b, Quarry Residuals Sampling Plan, DOE/OR/21548-382, Rev. A, prepared for U.S. Department of Energy, Oak Ridge Field Office, Weldon Spring Site Remedial Action Project, St. Charles, Mo., April.

Monette, F.A., 1992, "Daily Doses to Fish in Weldon Surface Waters," interoffice memorandum from F.A. Monette to M.M. MacDonell (Argonne National Laboratory, Argonne, Ill.), with attachment, April 21.

Nash, T., 1990, letter from T. Nash (U.S. Fish and Wildlife Service, Columbia Field Office, Columbia, Mo.) to I. Hlohowskyj (Argonne National Laboratory, Argonne, Ill.) with enclosures, May 9.

Neptune, D., et al., 1990, "Quantitative Decision Making in Superfund: A Data Quality Objectives Case Study," Hazardous Materials Control 3(3):19-27.

Niedermeyer, G.J., 1976, Assessment of Weldon Spring Chemical Plant in St. Charles County, Missouri, Report No. DRCPM-DRR-TR-76029, U.S. Department of the Army, Aberdeen Proving Ground, Md., March 1.

Pennak, A.F., 1975, Weldon Spring Decommissioning Study, Quarry Supplement, NCLO-1121 Sup. 1 (Special), prepared by National Lead Company of Ohio, Cincinnati, for U.S. Energy Research and Development Administration, Oak Ridge Operations Office, Oak Ridge, Tenn., Sept. 10.

Poston, T.M., and D.C. Klopfer, 1988, "Concentration Factors Used in the Assessment of Radiation Dose to Consumers of Fish: A Review of 27 Radionuclides," Health Physics 55: 751-766.

Richardson, R.M., 1960, Possible Use of Quarry at Mallinckrodt Chemical Works, Weldon Spring, Missouri, for the Disposal of Uranium Contaminated Building Debris and Rubble and Residues Containing Thorium and Uranium, U.S. Geological Survey, Indianapolis, Ind.

Roberts, C.M., and C.V. Theis, 1951, Preliminary Investigation of Ground Water Occurrences in the Weldon Springs Area, St. Charles County, Missouri, U.S. Geological Survey, Indianapolis, Ind., Dec. 
Ryckman/Edgerley/Tomlinson \& Associates, 1978, Phase III Report: Assessment of Disposition Alternatives, Weldon Spring Chemical Plant, St. Charles, Missouri, Data Requirement AOOB, prepared by Ryckman/Edgerley/Tomlinson \& Associates, St. Louis, Mo., for U.S. Department of the Army, Aberdeen Proving Ground, Md., May.

Sandstead, H.H., 1977, "Nutrient Interactions with Toxic Elements," in Advances in Modern Toxicology: Volume 2, Toxicology of Trace Elements, R.A. Goyer and M.A. Mehlman (editors), Hemisphere Publishing Corporation, Washington, D.C., pp. 241-256.

Sunderman, F.W., Jr., 1977, "Metal Carcinogenesis," in Advances in Modern Toxicology: Volume 2, Toxicology of Trace Elements, R.A. Goyer and M.A. Mehlman (editors), Hemisphere Publishing Corporation, Washington, D.C., pp. 257-295.

Swanson, S.M., 1983, "Levels of ${ }^{226} \mathrm{Ra},{ }^{210} \mathrm{~Pb}$, and ${ }^{\text {Total }} U$ in Fish near a Saskatchewan Uranium Mine and Mill," Health Physics 45:67-80.

Tieger, J., 1988, letter from J. Tieger (Field Supervisor, U.S. Fish and Wildlife Service, Columbia Field Office, Columbia, Mo.) to I. Hohowskyj (Environmental Assessment and Information Sciences Division, Argonne National Laboratory, Argonne, Ill.), Dec. 22.

Tucker, G., 1989, personal communication from G. Tucker (National Weather Service, St. Charles, Mo.) to M.J. Davis (Argonne National Laboratory, Argonne, Ill.), Dec. 18.

Tyler, G., et al., 1989, "Heavy-Metal Ecology of Terrestrial Plants, Microorganisms and Invertebrates, A Review," Water, Air, and Soil Pollution 47:189-215.

U.S. Army Corps of Engineers, 1988, data from Missouri River profile, Kansas City District, Kansas City, Mo.

U.S. Bureau of the Census, 1991, 1990 Census of Population and Housing, U.S. Department of Commerce, Washington, D.C.

U.S. Department of Energy, 1987, Draft Environmental Impact Statement, Remedial Action at the Weldon Spring Site, DOE/EIS-0177D, Office of Remedial Action and Waste Technology, Feb.

U.S. Department of Energy, 1989, Remedial Investigations for Quarry Bulk Wastes, DOE/OR/21548-066, Rev. 1, prepared by MK-Ferguson Company and Jacobs Engineering Group, Weldon Spring, Mo., for U.S. Department of Energy, Oak Ridge Operations Office, Weldon Spring Site Remedial Action Project, Weldon Spring, Mo., Dec.

U.S. Department of Energy, 1990a, Baseline Risk Evaluation for Exposure to Bulk Wastes at the Weldon Spring Quarry, Weldon Spring, Mo., DOE/OR/21548-065, prepared by Argonne National Laboratory, Environmental Assessment and Information Sciences Division, Argonne, IIl., for U.S. Department of Energy, Oak Ridge Operations Office, Weldon Spring Site Remedial Action Project, Weldon Spring, Mo., Jan. 
U.S. Department of Energy, 1990b, Feasibility Study for Management of the Bulk Wastes at the Weldon Spring Quarry, DOE/OR/21548-104, prepared by Environmental Assessment and Information Sciences Division, Argonne National Laboratory, Argonne, Ill., for U.S Department of Energy, Oak Ridge Operations Office, Weldon Spring Site Remedial Action Project, Weldon Spring, Mo., Feb.

U.S. Department of Energy, 1990c, Proposed Plan for the Management of Bulk Wastes at the Weldon Spring Quarry, Weldon Spring, Missouri, DOE/OR/21548-105, prepared by Argonne National Laboratory, Environmental Assessment and Information Sciences Division, Argonne, Ill., for U.S. Department of Energy, Oak Ridge Operations Office, Weldon Spring Site Remedial Action Project, St. Charles, Mo., Feb.

U.S. Department of Energy, 1990d, Responsiveness Summary for the Remedial Investigation / Feasibility Study for Management of Bulk Wastes at the Weldon Spring Quarry, Weldon Spring, Missouri, DOE/OR/21548-135, prepared by Argonne National Laboratory, Environmental Assessment and Information Sciences Division, Argonne, Ill., for U.S. Department of Energy, Oak Ridge Operations Office, Weldon Spring Site Remedial Action Project, St. Charles, Mo., Aug.

U.S. Department of Energy, 1992a, Baseline Assessment for the Chemical Plant Area of the Weldon Spring Site, DOE/OR/21548-091, prepared by U.S. Department of Energy, Oak Ridge Field Office, Weldon Spring Site Remedial Action Project, with technical assistance from Argonne National Laboratory, Environmental Assessment and Information Sciences Division, Nov.

U.S. Department of Energy, 1992b, Feasibility Study for Remedial Action at the Chemical Plant Area of the Weldon Spring Site, DOE/OR/21548-148, Vol. I, prepared by U.S. Department of Energy, Oak Ridge Field Office, Weldon Spring Site Remedial Action Project, with technical assistance from Argonne National Laboratory, Environmental Assessment and Information Sciences Division, Nov.

U.S. Department of Energy, 1992c, Proposed Plan for Remedial Action at the Chemical Plant Area of the Weldon Spring Site, DOE/OR/21548-160, prepared by U.S. Department of Energy, Oak Ridge Field Office, Weldon Spring Site Remedial Action Project, with technical assistance from Argonne National Laboratory, Environmental Assessment and Information Sciences Division, Nov.

U.S. Department of Energy, 1992d, Remedial Investigation for the Chemical Plant Area of the Weldon Spring Site, DOE/OR/21548-074, Rev. 0, Vols. I-II, prepared by MK-Ferguson Company and Jacobs Engineering Group, Weldon Spring, Mo., for U.S. Department of Energy, Oak Ridge Field Office, Weldon Spring Site Remedial Action Project, Weldon Spring, Mo., Nov.

U.S. Department of Energy, 1992e, Project Management Contractor Quality Assurance Program, Rev. 0, DOE/OR/21548-333, prepared by U.S. Department of Energv, Oak Ridge Field Office, Weldon Spring Site Remedial Action Project, Sept. 
U.S. Department of Energy, 1993, Responses to Comments on the Remedial Investigation/ Feasibility Study-Environmental Impact Statement for Remedial Action at the Chemical Plant Area of the Weldon Spring Site (November 1992), DOE/OR/21548-387, prepared by MK-Ferguson Company and Jacobs Engineering Group, Weldon Spring, Mn., for U.S. Department of Energy, Oak Ridge Field Office, Weldon Spring Site Remedial Action Project, Weldon Spring, Mo., June.

U.S. Environmental Protection Agency, 1983, Interim Guidelines and Specifications for the Preparation of Quality Assurance Project Plans, QAMS 005/80; EPA-600/4-83-004, Office of Monitoring Systems and Quality Assurance, Office of Research and Development, Feb.

U.S. Environmental Protection Agency, 1986, Quality Criteria for Water 1986, EPA 440/5-86001, Office of Water Regulations and Standards, Washington, D.C.,

U.S. Environmental Protection Agency, 1987, "National Priorities List for Uncontrolled Hazardous Waste Sites; Final Rule (40 CFR Part 300)," Federal Register 52:27620, July 22.

U.S. Environmental Protection Agency, 1988, Guidance for Conducting Remedial Investigations and Feasibility Studies under CERCLA, EPA/540/G-89/004, Interim Final, Office of Emergency and Remedial Response, Washington D.C., Oct.

U.S. Environmental Protection Agency, 1989a, "National Priorities List for Hazardous Waste Sites, Final Federal Facility Site Update; Final Rule (40 CFR Part 300)," Federal Register 54:10512, March 13.

U.S. Environmental Protection Agency, 1989b, Risk Assessment Guidance for Superfund, Volume I, Human Health Evaluation Manual, (Part A), EPA/540/1-89/002, Interim Final, Office of Emergency and Remedial Response, Washington D.C., Dec.

U.S. Environmental Protection Agency, 1989c, Ecological Assessment of Hazardous Waste Sites: A Field and Laboratory Reference, EPA 600/3-89/013, Environmental Research Laboratory, Corvallis, Oregon.

U.S. Environmental Protection Agency, 1989d, Risk Assessment Guidance for Superfund, Volume II: Environmental Evaluation Manual (Part A), Interim Final, EPA/540/1-89/002, Office of Solid Emergency and Remedial Response, Washington, D.C., Dec.

U.S. Environmental Protection Agency, 1990a, "National Oil and Hazardous Substances Pollution Contingency Plan; Final Rule (40 CFR Part 300)," Federal Register 55(46):86668865, March 8.

U.S. Environmental Protection Agency, 1990b, "National Priorities List for Uncontrolled Hazardous Waste Sites; Final Rule (40 CFR Part 300)," Federal Register 55(35):6154-6176, Feb. 21.

U.S. Environmental Protection Agency, 1992, Drinking Water Regulations and Health. Advisories, Office of Water, Washington, D.C., Nov. 
U.S. Nuclear Regulatory Commission, 1988, Radioactive Material in the West Lake Landfill, Summary Report, NUREG-1308, Office of Nuclear Material Safety and Safeguards, Washington, D.C., April.

Walters, G.R., 1988, A Phase I Cultural Resources Survey and Evaluation of the Weldon Spring Quarry Site Remedial Action Project Area, St. Charles County, Missouri, prepared by Triad Research Services, Columbia, Mo., for U.S. Department of Energy and MK-Ferguson Company, St. Charles, Mo.

Walters, G.R., 1990, A Phase I Survey and Evaluation of the Proposed Weldon Spring Quarry to Weldon Spring Chemical Plant Site Bulk Waste Haulage Road Project Area, St. Charles County, Missouri, prepared by Triad Research Services, Columbia, Mo., for U.S. Department of Energy and MK-Ferguson Company, St. Charles, Mo.

Walters, G.R., 1992, A Phase I Survey and Evaluation of a Proposed Borrow Area for the Weldon Spring Site Remedial Action Project, St. Charles County, Missouri, TRS CRM Report \#219, prepared by Triad Research Services, Columbia, Mo., for U.S. Department of Energy and MK-Ferguson Company, St. Charles, Mo., Jan. 15.

Weidner, R.B., and M.W. Boback, 1982, Weldon Spring Storage Site, Environmental Monitoring Report for 1979 and 1980, NCLO-1176 (Special), prepared by National Lead Company of Ohio, Cincinnati, for U.S. Department of Energy, Oak Ridge Operations Office, Oak Ridge, Tenn., April 19.

Whitfield, J.W., et al., 1989, Geologic Map of the Weldon Spring 7.5 Quadrangle, St. Charles County, Mo., OFM-89-252-GI, Missouri Department of Natural Resources, Division of Geology and Land Survey, Rolla, Mo. 



\section{APPENDL:}

DERIVATION OF RISK-BASED SOIL AND WATER CONCENTRATIONS 


\section{APPENDIX:}

\section{DERIVATION OF RISK-BASED SOIL AND WATER CONCENTRATIONS}

The calculated concentrations of radioactive and chemical contaminants in soil and groundwater that correspond to different levels of risk and hazard quotient are presented in this appendix. The contaminants considered are those identified in Section 3.1.2 as the preliminary contaminants for the quarry area. The risk-based concentrations for those contaminants were derived on the basis of methods provided in Risk Assessment Guidance for Superfund; Part B, Development of Risk-Based Preliminary Remediation Goals (EPA 1991). These risk-based concentrations provide input to the planning process for data quality objectives (Section 4.1) and are used to help develop the sampling plans for the quarry area. The results presented in this appendix are preliminary and will be revised in the future as the data quality objectives and sampling plans are further developed.

\section{A.1 SOIL}

A recreational visito. (or trespasser within the quarry proper) was identified as the most likely receptor at the quarry area under current land use and under hypothetical future conditions (Section 3.1). For this receptor, exposure to surface soil would be due primarily to direct ingestion of and dermal contact with soil and to inhalation of radon and airborne particulates derived from soil. For radioactive contaminants, external gamma irradiation would also be an exposure pathway. The risk-based soil concentrations are calculated by combining the appropriate intake and risk equations for these pathways, except for the dermal pathway. The dermal pathway is excluded because for most compounds the necessary parameters for calculating the risks associated with this pathway are not available.

Concentrations of radioactive contaminants in soil corresponding to specified risk levels were calculated as follows:

$$
R_{s i}=\frac{T R}{A+B+C+D}
$$

where:

$$
\begin{aligned}
& \mathrm{A}=\frac{6 \times 10^{-7}}{\mathrm{mrem}} \times \mathrm{EF} \times \mathrm{ED} \times \mathrm{IR}_{\mathrm{s}} \times \mathrm{CF}_{1} \times \mathrm{DCF}_{\mathrm{ing}} \\
& \mathrm{B}=\frac{6 \times 10^{-7}}{\mathrm{mrem}} \times \mathrm{ET} \times \mathrm{EF} \times \mathrm{ED} \times \mathrm{IR}_{\mathrm{a}} \times \mathrm{CF}_{2} \times \frac{1}{\mathrm{PEF}} \times \mathrm{DCF}_{\mathrm{inh}}
\end{aligned}
$$




$$
\begin{aligned}
& \mathrm{C}=\frac{6 \times 10^{-7}}{\mathrm{mrem}} \times \mathrm{ET} \times \mathrm{EF} \times \mathrm{ED} \times \mathrm{DCF}_{\gamma} ; \text { and } \\
& \mathrm{D}=2.5 \times 10^{-6} \times \mathrm{ET} \times \mathrm{EF} \times \mathrm{ED} \times \mathrm{IR}_{\mathrm{a}} \times \frac{3.5 \times 10^{-4}}{\mathrm{WLM}}
\end{aligned}
$$

(term $\mathrm{D}$ is only included for radium-226).

and:

$$
\begin{aligned}
& \mathbf{R}_{\mathrm{si}}=\text { soil concentration of radionuclide } \mathrm{i}(\mathrm{pCi} / \mathrm{g}) \text {; } \\
& \text { TR = excess individual lifetime cancer risk (unitless); } \\
& \mathrm{IR}_{\mathrm{a}}=\text { inhalation rate }\left(\mathrm{m}^{3} / \mathrm{h}\right) \text {; } \\
& \mathrm{IR}_{\mathrm{s}}=\text { soil ingestion rate (mg/event); } \\
& \mathrm{CF}_{1}=\text { conversion factor }\left(10^{-3} \mathrm{~g} / \mathrm{mg}\right) \text {; } \\
& \mathrm{CF}_{2}=\text { conversion factor }\left(10^{-3} \mathrm{~g} / \mathrm{kg}\right) \text {; } \\
& \mathrm{ED}=\text { exposure duration }(\mathrm{yr}) \text {; } \\
& E F=\text { exposure frequency (events/yr or } d / y r) ; \\
& \text { ET = exposure time }(\text { h/event); } \\
& \mathrm{PEF}=\text { particulate emission factor }\left(4.63 \times 10^{9} \mathrm{~m}^{3} / \mathrm{kg}\right. \text { [EPA 1991]), } \\
& \mathrm{DCF}_{\gamma}=\text { external gamma dose conversion factor for radionuclide } i \\
& {[(\mathrm{mrem} / \mathrm{h}) /(\mathrm{pCi} / \mathrm{g})] \text { (see Table } 4.1 \text { of the baseline assessment (BA) }} \\
& \text { for the chemical plant area [DOE 1992]); } \\
& \begin{aligned}
\mathrm{DCF}_{\text {ing }}= & \text { ingestion dose conversion factor for adionuclide } \mathrm{i}(\mathrm{mrem} / \mathrm{pCi}) \\
& \text { (see Table } 4.1 \text { of the BA for the chemical plant area); }
\end{aligned} \\
& \mathrm{DCF}_{\text {inh }}=\text { inhalation dose conversion factor for radionuclide } \mathrm{i}(\mathrm{mrem} / \mathrm{pCi}) \\
& \text { (see Table } 4.1 \text { of the BA for the chemical plant area); and } \\
& \text { WLM = working level month. }
\end{aligned}
$$

Term D is included in Equation A.1 to incorporate inhalation of radon-222 generated from radium-226 in soil. A comprehensive discussion of the radon pathway, including equations, is provided in Section 3 of the BA for the chemical plant area (DOE 1992), and the risk factors used in Equation A.1 are discussed in Section 4.1 of the BA. 
For chemical contaminants, the concentrations corresponding to specified risk levels were calculated as follows:

$$
\mathrm{C}_{\mathrm{si}}=\frac{\mathrm{TR} \times \mathrm{BW} \times \mathrm{AT} \times \mathrm{CF}_{4}}{(\mathrm{EF} \times \mathrm{ED})\left[\left(\mathrm{SF}_{\mathrm{oi}} \times \mathrm{CF}_{3} \times \mathrm{IR}_{\mathrm{s}}\right)+\left(\mathrm{SF}_{\mathrm{ii}} \times \mathrm{IR}_{\mathrm{a}} \times \mathrm{ET} \times 1 / \mathrm{PEF}\right)\right]}
$$

where:

$$
\begin{aligned}
& \mathrm{C}_{\mathrm{si}}=\text { soil concentration of contaminant } \mathrm{i}(\mathrm{mg} / \mathrm{kg}) ; \\
& \mathrm{BW}=\text { average body weight over the exposure period }(\mathrm{kg}) ; \\
& \mathrm{AT}=\text { averaging time }(\mathrm{yr}) ; \\
& \mathrm{CF}_{3}=\text { conversion factor }\left(10^{-6} \mathrm{~kg} / \mathrm{mg}\right) ; \\
& \mathrm{CF}_{4}=\text { conversion factor }(365 \mathrm{~d} / \mathrm{yr}) ; \\
& \mathrm{SF}_{\mathrm{oi}}=\text { oral slope factor for contaminant } \mathrm{i}\left([\mathrm{mg} / \mathrm{kg}-\mathrm{d}]^{-1}\right) ; \text { and } \\
& \mathrm{SF}_{\mathrm{ii}}=\text { inhalation slope factor for contaminant } \mathrm{i}\left([\mathrm{mg} / \mathrm{kg}-\mathrm{d}]^{-1}\right) .
\end{aligned}
$$
follows:

The concentrations corresponding to specified hazard quotients were calculated as

$$
\mathrm{C}_{\mathrm{si}}=\frac{\mathrm{THI} \times \mathrm{BW} \times \mathrm{AT} \times \mathrm{CF}_{4}}{(\mathrm{EF} \times \mathrm{ED})\left[\left(1 / \mathrm{RfD}_{\mathrm{oi}} \times \mathrm{CF}_{3} \times \mathrm{IR}_{\mathrm{s}}\right)+\left(1 / \mathrm{RfD}_{\mathrm{ii}} \times \mathrm{IR}_{\mathrm{a}} \times \mathrm{ET} \times 1 / \mathrm{PEF}\right)\right]}
$$

where:

THI = target hazard index (unitless);

$\mathrm{RfD}_{\mathrm{oi}}=$ oral reference dose for contaminant $\mathrm{i}(\mathrm{mg} / \mathrm{kg}-\mathrm{d}) ;$ and

$\mathrm{RfD}_{\mathrm{ii}}=$ inhalation reference dose for contaminant $\mathrm{i}(\mathrm{mg} / \mathrm{kg}-\mathrm{d})$.

The toxicity values used in Equations A.2 and A.3 are discussed in Chapter 4 of the BA. Because the EPA continues to develop new and revise previous toxicity values as new information becomes available, the values presented in the BA were updated with information presented in EPA's Integrated Risk Information System (IRIS) (EPA 1993) and Health Effects Assessment Summary Tables (HEAST) (EPA 1992). For compounds for which a toxicity value had been withdrawn from IRIS or HEAST subsequent to its use in the BA, the value listed in the BA was used for the purpose of the preliminary calculations presented in this appendix. 
The assumptions and intake parameters assumed for the recreational visitor are summarized in Table A.1. For this preliminary assessment, these values are the same as those used for the future recreational visitor assessed in the BA for the chemical plant area, as described in Section 3.4.2 of that document (DOE 1992). The soil concentrations of radioactive contaminants that correspond to different levels of risk are shown in Table A.2; those for the chemical contaminants are shown in Tables A.3 and A.4.

\section{A.2 GROUNDWATEF}

Under both current and future conditions, groundwater is not expected to represent a complete exposure pathway. That is, no receptors have been identified because groundwater in the alluvial aquifer in areas with elevated contaminant concentrations is not used for residential, agricultural, or other purposes (Section 3.1.4). However, the concentrations of radioactive and chemical contaminants in groundwater that correspond to different levels of risk and hazard quotient are estimated to help support development of the sampling plans. For this purpose, the receptor is assumed to be an individual ingesting $2 \mathrm{~L} / \mathrm{d}$ of water.

TABLE A.1 Exposure Scenario Assumptions and Intake Parameters

\begin{tabular}{|c|c|c|c|}
\hline Parameter & Variable $^{a}$ & $\begin{array}{c}\text { Current/Future } \\
\text { Recreational } \\
\text { Visitor } \\
\end{array}$ & $\begin{array}{c}\text { Groundwater } \\
\text { User }\end{array}$ \\
\hline Average body weight (kg) & BW & 70 & 70 \\
\hline Inhalation rate $\left(\mathrm{m}^{3} / \mathrm{h}\right)$ & $\mathrm{IR}_{\mathrm{a}}$ & 2.1 & $-\mathrm{b}$ \\
\hline $\begin{array}{l}\text { Incidental ingestion of contaminated soil } \\
\text { (mg/event) }\end{array}$ & $\mathrm{IR}_{\mathrm{B}}$ & 120 & - \\
\hline Water ingestion rate $(\mathrm{L} / \mathrm{d})$ & $\mathrm{IR}_{\mathrm{w}}$ & - & 2 \\
\hline Exposure time (h/event) & $\mathrm{ET}$ & 4 & - \\
\hline Exposure frequency (events/yr or $\mathrm{d} / \mathrm{yr}$ ) & EF & 20 & 350 \\
\hline Exposure duration (yr) & ED & 30 & 30 \\
\hline $\begin{array}{l}\text { Averaging time } \\
\text { Carcinogens (yr) } \\
\text { Noncarcinogens (yr) }\end{array}$ & AT & $\begin{array}{l}70 \\
30\end{array}$ & $\begin{array}{l}70 \\
30\end{array}$ \\
\hline
\end{tabular}

a The listed variables are used in Equations A.1 through A.6.

b A hyphen indicates that the entry is not applicable. 
TABLE A.2 Soil and Water Concentrations of Radionuclides Associated with Target Risk Levels ${ }^{\mathrm{a}}$

\begin{tabular}{|c|c|c|c|}
\hline \multirow[b]{2}{*}{ Radionuclide } & \multicolumn{3}{|c|}{$\begin{array}{c}\text { Soil Concentration (pCi/g) } \\
\text { Relative to Risk }\end{array}$} \\
\hline & $1 \times 10^{-6}$ & $1 \times 10^{-5}$ & $1 \times 10^{-4}$ \\
\hline $\begin{array}{l}\text { Actinium--227 } \\
\text { Lead-210 } \\
\text { Protactinium-231 } \\
\text { Radium-226 } \\
\text { Radium-228 } \\
\text { Thorium-230 } \\
\text { Thorium-232 } \\
\text { Uranium-235 } \\
\text { Uranium-238 }\end{array}$ & $\begin{array}{c}0.90 \\
3.4 \\
1.9 \\
0.14 \\
0.43 \\
42 \\
8.0 \\
6.5 \\
24\end{array}$ & $\begin{array}{c}9.0 \\
34 \\
19 \\
1.4 \\
4.3 \\
420 \\
80 \\
65 \\
240\end{array}$ & $\begin{array}{c}90 \\
340 \\
190 \\
14 \\
43 \\
4,200 \\
800 \\
650 \\
2,400\end{array}$ \\
\hline Uranium-238 $^{\mathrm{C}}$ & \multicolumn{3}{|c|}{$\begin{array}{c}\text { Water Concentration }(\mathrm{pCi} / \mathrm{L}) \\
\text { Relative to Risk }\end{array}$} \\
\hline Radionuclide & $1 \times 10^{-6}$ & $1 \times 10^{-5}$ & $1 \times 10^{-4}$ \\
\hline $\begin{array}{l}\text { Actinium-227 } \\
\text { Lead-210 } \\
\text { Protactinium-231 } \\
\text { Radium-226 }^{\mathrm{b}} \\
\text { Radium-228 } \\
\text { Thorium-230 } \\
\text { Thorium-232 } \\
\text { Uranium-235 }^{\mathrm{c}} \\
\text { Uranium-238 }^{\mathrm{c}}\end{array}$ & $\begin{array}{c}0.0053 \\
0.012 \\
0.0072 \\
0.072 \\
0.062 \\
0.15 \\
0.028 \\
0.32 \\
0.16\end{array}$ & $\begin{array}{c}0.053 \\
0.12 \\
0.072 \\
0.72 \\
0.62 \\
1.5 \\
0.28 \\
3.2 \\
1.6\end{array}$ & $\begin{array}{c}0.53 \\
1.2 \\
0.72 \\
7.2 \\
6.2 \\
15 \\
2.8 \\
32 \\
16\end{array}$ \\
\hline
\end{tabular}

a Soil concentrations were calculated on the basis of the ingestion, inhalation, and external gamma pathways; water concentrations were calculated on the basis of the ingestion pathway.

b Radium-226 soil concentrations include the contribution from inhalation of radon-222. For groundwater concentrations, the contribution from radon as a result of volatilization would be insignificant compared to ingestion of radium-226 in drinking water.

c The risk from radium-228 includes the contribution from thorium-228, and the risk from uranium-238 includes the contribution from uranium-234. 
TABLE A.3 Soil and Water Concentrations of Chemicals Associated with Target Risk Levels"

\begin{tabular}{|c|c|c|c|}
\hline \multirow[b]{2}{*}{ Chemical $^{b}$} & \multicolumn{3}{|c|}{$\begin{array}{l}\text { Soil Concentration (mg/kg) } \\
\text { Relative to Risk }\end{array}$} \\
\hline & $1 \times 10^{-6}$ & $1 \times 10^{-5}$ & $1 \times 10^{-4}$ \\
\hline $\begin{array}{l}\text { Metals } \\
\text { Arsenic } \\
\text { Beryllium } \\
\text { Cadmium } \\
\text { Chromium (VI) } \\
\text { Nickel }\end{array}$ & $\begin{array}{c}14 \\
5.8 \\
270,000 \\
40,000 \\
>500,000\end{array}$ & $\begin{array}{c}140 \\
58 \\
>500,000 \\
400,000 \\
>500,000\end{array}$ & $\begin{array}{c}1,400 \\
580 \\
>500,000 \\
>500,000 \\
>500,000\end{array}$ \\
\hline \multirow[t]{2}{*}{$\begin{array}{l}\text { Nitroaromatic } \\
\text { compounds } \\
2,4-D N T \\
2,6-D N T \\
\text { TNT }\end{array}$} & $\begin{array}{c}37 \\
37 \\
830\end{array}$ & $\begin{array}{c}370 \\
370 \\
8,300\end{array}$ & $\begin{array}{l}3,700 \\
3,700 \\
83,000\end{array}$ \\
\hline & \multicolumn{3}{|c|}{$\begin{array}{l}\text { Water Concentration ( } \mu \mathrm{g} / \mathrm{L}) \\
\text { Relative to Risk }\end{array}$} \\
\hline Chemical $^{b}$ & $1 \times 10^{-6}$ & $1 \times 10^{-5}$ & $1 \times 10^{-4}$ \\
\hline $\begin{array}{l}\text { Metals } \\
\text { Arsenic } \\
\text { Beryllium }\end{array}$ & $\begin{array}{l}0.047 \\
0.020\end{array}$ & $\begin{array}{l}0.47 \\
0.20\end{array}$ & $\begin{array}{l}4.7 \\
2.0\end{array}$ \\
\hline $\begin{array}{l}\text { Nitroaromatic } \\
\text { compounds } \\
2,4-\mathrm{DNT} \\
2,6-\mathrm{DNT} \\
\text { TNT }\end{array}$ & $\begin{array}{c}0.13 \\
0.13 \\
2.8\end{array}$ & $\begin{array}{l}1.3 \\
1.3 \\
28\end{array}$ & $\begin{array}{c}13 \\
13 \\
280\end{array}$ \\
\hline
\end{tabular}

a Soil concentrations were calculated on the basis of the ingestion and inhalation pathways; water concentrations were calculated on the basis of the ingestion pathway.

b Listed are only those contaminants for which an oral or inhalation slope factor is available. 
TABLE A.4 Soil and Water Concentrations of Chemicals Associated with Target Hazard Quotients"

\begin{tabular}{|c|c|c|c|c|}
\hline \multirow[b]{2}{*}{ Chemical } & \multicolumn{4}{|c|}{ Soil Concentration $(\mathrm{mg} / \mathrm{kg}$ ) Relative to Hazard Quotient } \\
\hline & 0.1 & 0.3 & 0.5 & 1 \\
\hline \multicolumn{5}{|l|}{ Metals } \\
\hline Aluminum & NQ & NQ & NQ & $\mathrm{NQ}^{\mathrm{b}}$ \\
\hline Antimony & 430 & 1,300 & 2,100 & 4,300 \\
\hline Arsenic & 320 & 960 & 1,600 & 3,200 \\
\hline Barium & 74,000 & 220,000 & 370,000 & $>500,000$ \\
\hline Beryllium & $\mathbf{5 , 3 0 0}$ & 16,000 & 27,000 & 53,000 \\
\hline Cadmium & 1,100 & 3,200 & 5,300 & 11,000 \\
\hline Calcium & NQ & NQ & NQ & NQ \\
\hline Chromium (III) & 41,000 & 120,000 & 200,000 & 410,000 \\
\hline Chromium (VI) & 4,700 & 14,000 & 24,000 & 47,000 \\
\hline Cobalt & NQ & NQ & NQ & NQ \\
\hline Copper & 43,000 & 130,000 & 210,000 & 430,000 \\
\hline Iron & NQ & NQ & NQ & NQ \\
\hline Lead & NQ & NQ & NQ & NQ \\
\hline Lithium & 21,000 & 64,000 & 110,000 & 210,000 \\
\hline Magnesium & NQ & NQ & NQ & NQ \\
\hline Manganese & 105,000 & 310,000 & $>500,000$ & $>500,000$ \\
\hline Mercury & 320 & 960 & 1,600 & 3,200 \\
\hline Molybdenum & 5,300 & 16,000 & 27,000 & 53,000 \\
\hline Nickel & 21,000 & 64,000 & 110,000 & 210,000 \\
\hline Potassium & NQ & NQ & NQ & NQ \\
\hline Selenium & 5,300 & 16,000 & 27,000 & 53,000 \\
\hline Silver & 5,300 & 16,000 & 27,000 & 53,000 \\
\hline Sodium & NQ & NQ & NQ & NQ \\
\hline Thallium & 75 & 220 & 370 & 750 \\
\hline Uranium & 3,200 & 9,600 & 16,000 & 32,000 \\
\hline Vanadium & 7,500 & 22,000 & 37,000 & 75,000 \\
\hline Zinc & 320,000 & $>500,000$ & $>500,000$ & $>500,000$ \\
\hline \multicolumn{5}{|l|}{ Inorganic anions } \\
\hline Chloride & NQ & NQ & NQ & NQ \\
\hline Fluoride & 64,000 & 190,000 & 320,000 & $>500,000$ \\
\hline Nitrate (as N) & 12,000 & 36,000 & 60,000 & 120,000 \\
\hline Nitrite (as N) ${ }^{c}$ & 750 & 2,300 & 3,800 & 7,500 \\
\hline Sulfate & NQ & NQ & NQ & NQ \\
\hline \multicolumn{5}{|l|}{$\begin{array}{l}\text { Nitroaromatic } \\
\text { compounds }\end{array}$} \\
\hline DNB & 110 & 320 & 530 & 1,100 \\
\hline 2,4-DNT & 2,100 & 6,400 & 11,000 & 21,000 \\
\hline 2,6-DNT & 4,300 & 13,000 & 21,000 & 43,000 \\
\hline NB & 530 & 1,600 & 2,700 & 5,300 \\
\hline TNB & 53 & 160 & 270 & 530 \\
\hline TNT & 530 & 1,600 & 2,700 & 5,300 \\
\hline
\end{tabular}


TABLE A.4 (Cont.)

\begin{tabular}{|c|c|c|c|c|}
\hline \multirow[b]{2}{*}{ Chemical } & \multicolumn{4}{|c|}{ Water Concentration $(\mu g / L)$ Relative to Hazard Quotient } \\
\hline & 0.1 & 0.3 & 0.5 & 1 \\
\hline \multicolumn{5}{|l|}{ Metals } \\
\hline Aluminum & NQ & NQ & NQ & NQ \\
\hline Antimony & 1.5 & 4.4 & 7.3 & 15 \\
\hline Arsenic & 1.1 & 3.3 & 5.5 & 11 \\
\hline Barium & 260 & 770 & 1,300 & 2,600 \\
\hline Beryllium & 18 & $\mathbf{6 5}$ & 91 & 180 \\
\hline Cadmium & 1.8 & 5.5 & 9.1 & 18 \\
\hline Calcium & NQ & NQ & NQ & NQ \\
\hline Chromium (III) & $\mathbf{3 , 7 0 0}$ & 11,000 & 18,000 & 37,000 \\
\hline Chromium (VI) & 18 & 55 & 91 & 180 \\
\hline Cobalt & NQ & NQ & NQ & NQ \\
\hline Copper & 150 & 440 & 730 & 1,500 \\
\hline Iron & NQ & NQ & NQ & NQ \\
\hline Lead & NQ & NQ & NQ & $\mathbf{N Q}$ \\
\hline Lithium & 73 & 220 & 370 & 730 \\
\hline Magnesium & NQ & NQ & NQ & NQ \\
\hline Manganese & 18 & 55 & 91 & 180 \\
\hline Mercury & 1.1 & 3.3 & 5.5 & 11 \\
\hline Molybdenum & 18 & 65 & 91 & 180 \\
\hline Nickel & 73 & 220 & 370 & 730 \\
\hline Potassium & NQ & NQ & NQ & NQ \\
\hline Selenium & 18 & 55 & 91 & 180 \\
\hline Silver & 18 & 55 & 91 & 180 \\
\hline Sodium & NQ & NQ & NQ & NQ \\
\hline Thallium & 0.26 & 0.77 & 1.3 & 2.6 \\
\hline Uranium & 11 & 33 & 55 & 110 \\
\hline Vanadium & 26 & 77 & 130 & 260 \\
\hline Zinc & 1,100 & 3,300 & 5,500 & 11,000 \\
\hline \multicolumn{5}{|l|}{ Inorganic anions } \\
\hline Chloride & NQ & NQ & NQ & NQ \\
\hline Fluoride & 220 & 660 & 1,100 & 2,200 \\
\hline Nitrate (as N) & 1,000 & 3,000 & 5,000 & 10,000 \\
\hline Nitrite (as N) & 100 & 300 & 500 & 1,000 \\
\hline Sulfate & NQ & NQ & NQ & NQ \\
\hline \multicolumn{5}{|l|}{$\begin{array}{l}\text { Nitroaromatic } \\
\text { compounds }\end{array}$} \\
\hline DNB & 0.37 & 1.1 & 1.8 & 3.7 \\
\hline 2,4-DNT & 7.3 & 22 & 37 & 73 \\
\hline 2,6-DNT & 15 & 44 & 73 & 150 \\
\hline NB & 1.8 & 5.5 & 9.1 & 18 \\
\hline TNB & 0.18 & 0.55 & 0.91 & 1.8 \\
\hline TNT & 1.8 & 5.5 & 9.1 & 18 \\
\hline
\end{tabular}

See next page for footnotes. 


\section{TABLE A.4 (Cont.)}

a Soil concentrations were calculated on the basis of the ingestion and inhalation pathways; water concentrations were calculated on the basis of the ingestion pathway.

b NQ indicates not quantified because a toxicity value was not available.

c Because the critical effect associated with exposure to nitrate and nitrite is an acute response (methemoglobinemia), the soil concentration has been derived on the basis of a single exposure of a 15-kg child ingesting $200 \mathrm{mg}$ of soil, which is averaged over an exposure duration of one day. This results in a more conservative (lower) concentration than the value derived from the assumptions and intake parameters in Table A.1.

d The concentrations of 10,000 and 1,000 $\mu \mathrm{g} / \mathrm{L}$ correspond to the MCLs for nitrate and nitrate (as nitrogen), derived for a 4-kg infant ingesting $0.64 \mathrm{~L}$ of water per day (EPA 1993). For nitrate, an additional uncertainty factor of 10 is applied because of the direct toxicity of this compound. These concentrations are more conservative than those derived from the assumptions and intake parameters in Table A.1.

Concentrations of radioactive contaminants in groundwater corresponding to specified risk levels were calculated as follows:

$$
R_{\mathrm{gwi}}=\frac{\mathrm{TR}}{\mathrm{IR}_{\mathrm{w}} \times \mathrm{EF} \times \mathrm{ED} \times \mathrm{DCF}_{\mathrm{ing}} \times \frac{6 \times 10^{-7}}{\mathrm{mrem}}}
$$

where:

$$
\begin{aligned}
& R_{g w i}=\text { groundwater concentration of contaminant } i(p C i / L) ; \text { and } \\
& I_{w}=\text { groundwater ingestion rate }(L / d) .
\end{aligned}
$$

For chemical contaminants, the concentrations corresponding to specified risk levels were calculated as follows:

$$
\mathrm{C}_{\mathrm{gwi}}=\frac{\mathrm{TR} \times \mathrm{BW} \times \mathrm{AT} \times \mathrm{CF}_{4} \times \mathrm{CF}_{5}}{\mathrm{SF}_{\mathrm{oi}} \times \mathrm{IR}_{\mathrm{w}} \times \mathrm{EF} \times \mathrm{ED}}
$$

where:

$$
\begin{aligned}
& C_{g w i}=\text { groundwater concentration of contaminant } i(\mu \mathrm{g} / \mathrm{L}) ; \text { and } \\
& \mathrm{CF}_{5}=\text { conversion faction }\left(10^{3} \mu \mathrm{g} / \mathrm{mg}\right)
\end{aligned}
$$


The concentrations corresponding to specified levels of hazard quotient were calculated as follows:

$$
\mathrm{C}_{\mathrm{gwi}}=\frac{\mathrm{THI} \times \mathrm{RfD}_{\mathrm{oi}} \times \mathrm{BW} \times \mathrm{AT} \times \mathrm{CF}_{4} \times \mathrm{CF}_{5}}{\mathrm{IR}_{\mathrm{w}} \times \mathrm{EF} \times \mathrm{ED}}
$$

The assumptions and intake parameters used for the assessment of this pathway are summarized in Table A.1, and the toxicity values are discussed in Section A.1. The groundwater concentrations of radioactive and chemical contaminants that correspond to different levels of risk and hazard index are presented in Tables A.2, A.3, and A.4.

\section{A.3 REFERENCES (APPENDIX)}

U.S. Department of Energy, 1992, Baseline Assessment for the Chemical Plant Area of the Weldon Spring Site, DOE/OR/21548-091, prepared by Argonne National Laboratory, Environmental Assessment and Information Sciences Division, Argonne, Ill., for U.S. Department of Energy, Oak Ridge Field Office, Weldon Spring Site Remedial Action Project, St. Charles, Mo., Nov.

U.S. Environmental Protection Agency, 1991, Risk Assessment Guidance for Superfund, Volume I: Human Health Evaluation Manual (Part B, Development of Risk-Based Preliminary Remediation Goals), Interim, EPA/540/R-92/003, Office of Emergency and Remedial Response, Washington, D.C., Dec.

U.S. Environmental Protection Agency, 1992, Health Effects Assessment Summary Tables, OERR 9200.6-303(91-1), Office of Emergency and Remedial Response, Annual, FY-1992, March.

U.S. Environmental Protection Agency, 1993, Integrated Risk Information System, Office of Research and Development, database, accessed March. 


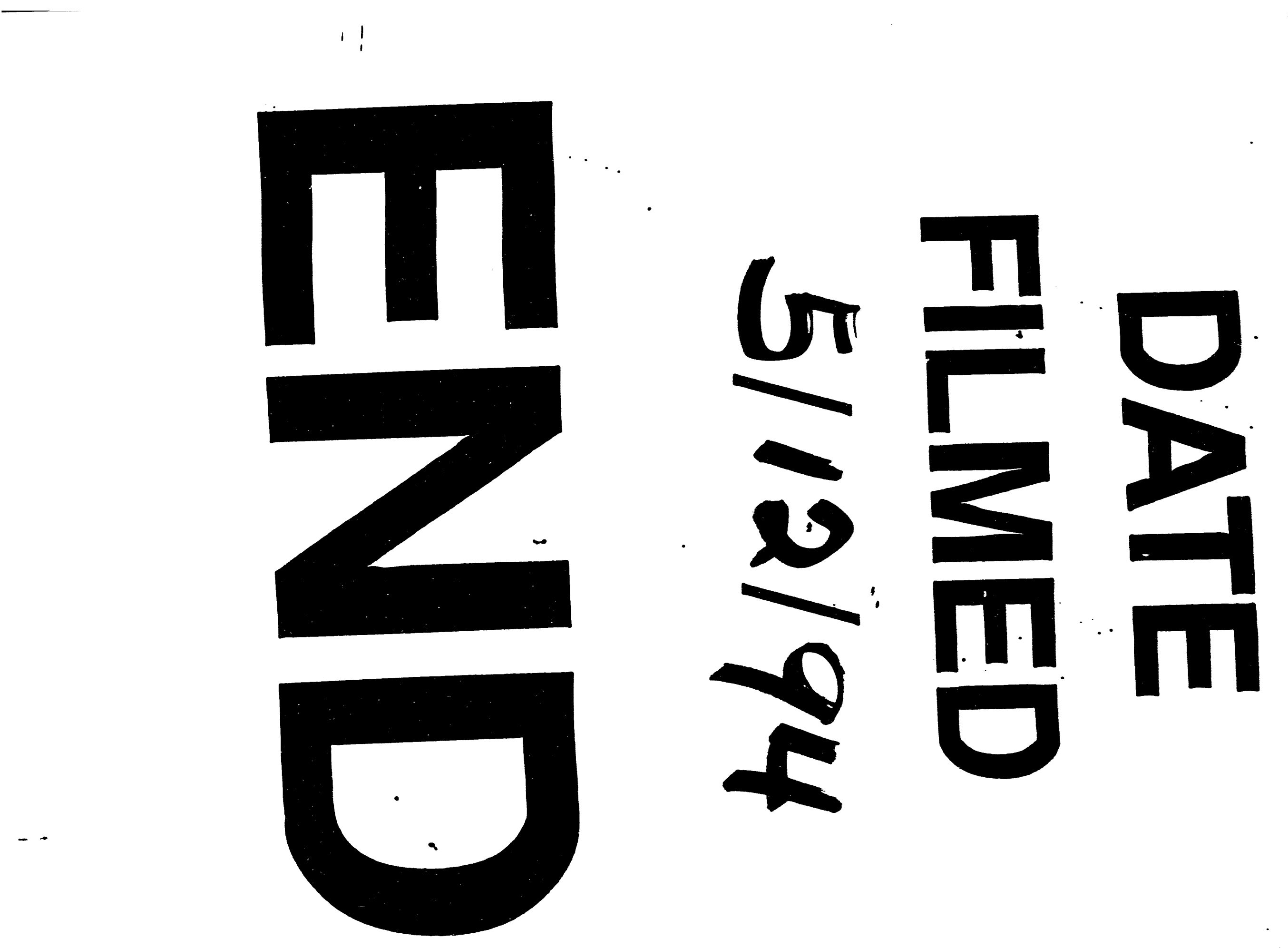




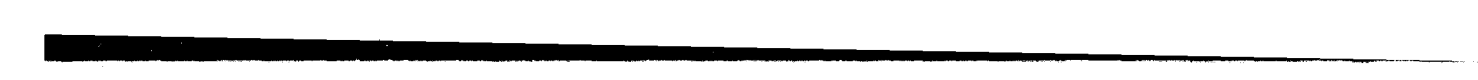

